\author{
Universidade de São Paulo \\ Escola de Engenharia de São Carlos \\ Departamento de Hidráulica e Saneamento \\ Programa de Pós-Graduação em Ciências da Engenharia Ambiental
}

\title{
Análise da eficiência de um sistema combinado de alagados construídos na melhoria da qualidade das águas
}

Caroline de Andrade Gomes da Cunha

Dissertação apresentada à Escola de

Engenharia de São Carlos, da

Universidade de São Paulo, como parte dos requisitos para obtenção do Título de Mestre em Ciências da

Engenharia Ambiental

Orientadora:

Profa. Dra. Eneida Salati.

São Carlos - SP 
“Quando sonhamos sós, é só um sonho; mas quando sonhamos juntos é o início de uma nova realidade”

Dom Helder Câmara 
Dedico este trabalho:

Aos meus pais Marcia e Paulo, que nunca mediram esforços para que eu pudesse realizar todos os meus sonhos; Aos meus irmãos Paola e Felipe pelo amor e carinho; Aos meus avós que sempre incentivaram meu estudo. 


\section{AGRADECIMENTOS}

A Deus que me deu força, saúde e perseverança para a realização deste trabalho;

A Fundação Capes pela concessão da bolsa de estudos durante o Mestrado;

A Prof. Dra. Eneida Salati pela oportunidade e pelos conhecimentos transmitidos durante sua orientação, mas principalmente por seus conselhos, carinho e amizade;

Ao Prof. Dr. Antônio Carlos Pião pela atenção e colaboração com as análises estatísticas do trabalho;

A Profa. Dra. Maria do Carmo Calijuri na condição de membro da banca de defesa, pela atenção e sugestões dadas ao meu trabalho na qualificação e na defesa deste trabalho e na condição de presidente da comissão de pós-graduação, por defender meus interesses;

Ao Dr. Evaldo L. G. Espíndola pela atenção e sugestões dadas ao meu trabalho na qualificação;

Ao Prof. Dr. Frederico de Almeida L. Filho pelas correções e sugestões dadas na dissertação;

A amiga Fernanda Teixeira Marciano também pela ajuda nas análises estatísticas da dissertação;

A secretária do PPG/SEA e amiga Claudete que não mediu esforços para que esse trabalho pudesse ser concluído. Muito obrigada pelo carinho, pela atenção, pela força e por tentar e conseguir me ajudar a resolver os problemas burocráticos para entrega desta dissertação;

A todos os funcionários do CRHEA, em especial à Mara, ao Achilles e ao Wellington pelas conversas e recursos disponibilizados;

Ao Instituto Terramax, especialmente ao João Marcelo pelos esclarecimentos sobre as coletas e os dados do trabalho, mas principalmente pelo carinho e atenção em todos os momentos que precisei;

A Companhia de Saneamento Básico de São Paulo, em especial a Ana Lúcia pelos dados disponibilizados sobre o Parque Ecológico Tietê, e a química Rosemeire do Laboratório de Inorgânicos, pelos esclarecimentos sobre a metodologia do trabalho e pela atenção; 
Aos funcionários do Parque Ecológico do Tietê, e ao arquiteto Júnior por nos receber tão bem e por nos esclarecer algumas dúvidas sobre o funcionamento do parque;

Ao Departamento de Ciências Atmosféricas do Instituto Astronômico e Geofísico da Universidade de São Paulo (IAG-USP), pelo fornecimento dos dados de temperatura do ar e de precipitação pluviométrica;

Aos meus eternos amigos de Ribeirão Preto, Andréia, Carlos, Danielle, Fernando, Juliana, Maíra e Thiago pela amizade, apoio e por perdoarem a minha ausência durante a fase final deste trabalho;

As minhas companheiras de apartamento Ana Lúcia, Marcela, Patrícia e Roberta pela amizade, pelo incentivo e pelos preciosos conselhos tanto para elaboração deste trabalho como para a vida;

A Roberta e ao Guto, companheiros de final de semana em São Carlos, pela paciência, pelo carinho, por me ajudarem nos assuntos relacionados a parte de informática, mas principalmente por estarem ao meu lado na parte final desta dissertação, me apoiando e dando força.

Aos meus mais novos amigos de Fortaleza, Cláudio e Mariano e aos demais colegas do curso pelo apoio, descontração e carinho durante o período das disciplinas;

A minha amiga de Ribeirão e São Carlos, Juliana pela atenção, ajuda, carinho e torcida por minhas conquistas;

Ao Eduardo pelo amor e companheirismo, conselhos e incentivos durante a realização deste trabalho, estando perto ou longe sempre disposto a me ouvir e a me ajudar;

Às minhas sobrinhas Cecília e Ana Clara, fontes de amor e alegria, por entenderem os meus momentos de ausência;

Aos meus pais e irmãos que sempre acreditaram em mim e me incentivaram, com muito amor e carinho, a continuar nessa caminhada em busca ao conhecimento;

Enfim, a todos aqueles, que direta ou indiretamente, contribuíram para que eu pudesse alcançar os meus objetivos. 


\section{SUMÁRIO}

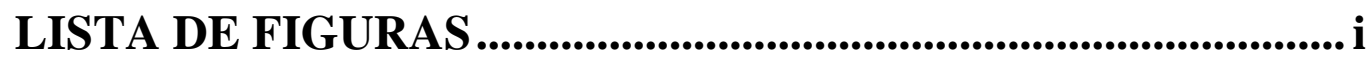

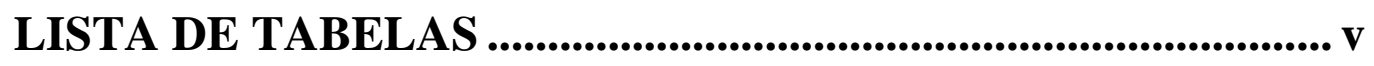

LISTA DE SÍMBOLOS E ABREVIAÇÕES...................................vii

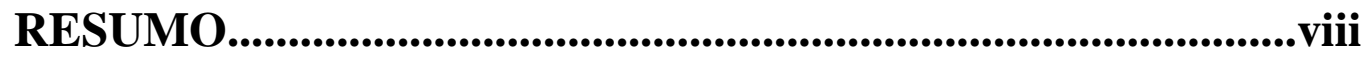

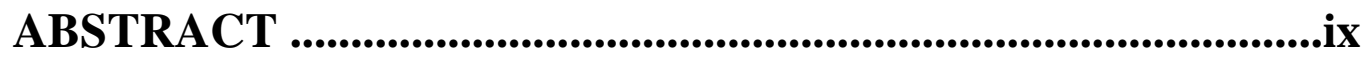

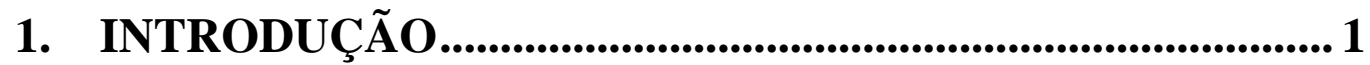

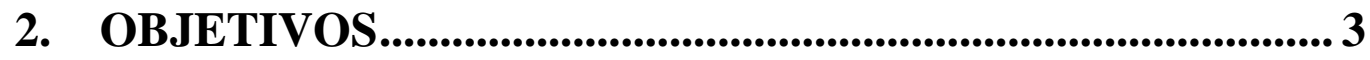

3. REVISÃO BIBLIOGRÁFICA …............................................... 3

3.1. Áreas Alagadas Naturais ...............................................................................

3.2. Áreas Alagadas Construídas .........................................................................

3.2.1. Tipos de áreas alagadas construídas...............................................10

3.2.1.1. Sistemas que utilizam plantas aquáticas flutuantes.....................11

3.2.1.2. Sistemas que utilizam plantas aquáticas emergentes ..................12

3.2.1.3. Sistemas que utilizam plantas aquáticas submersas ....................13

3.2.1.4. Sistemas de despoluição hídrica com solos filtrantes (DHS).....13

3.2.1.5. Sistemas de Wetlands combinados............................................... 15

3.2.2. Processos de Remoção de Poluentes .................................................... 15

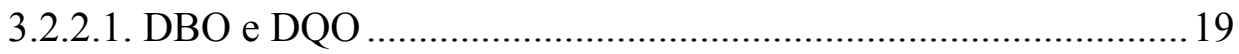

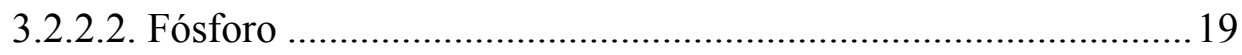

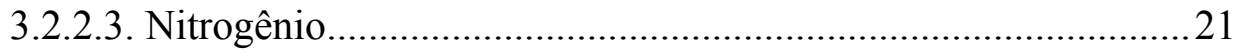

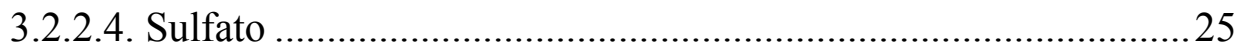

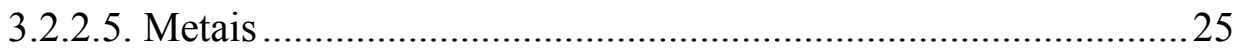

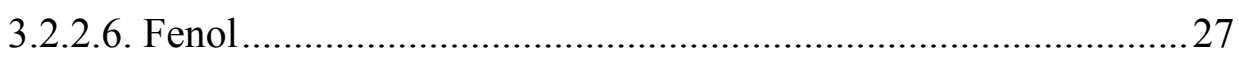

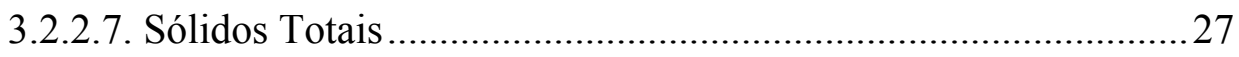

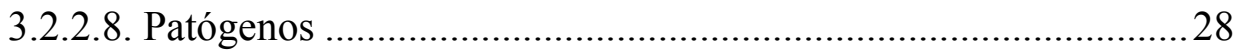

3.2.3. Áreas Alagadas Construídas no Brasil ..............................................28 
4. MATERIAL E MÉTODOS

4.1. Local de Estudo .................................................................................................35

4.1.1. Descrição da estação de tratamento ………………………………......37

4.1.1.1. Canal de macrófitas aquáticas flutuantes e emergentes (MAFE):

4.1.1.2. Sistema de despoluição hídrica com solos filtrantes (DHS): .....40

4.2. Período de coleta e pontos de amostragem ...............................................42

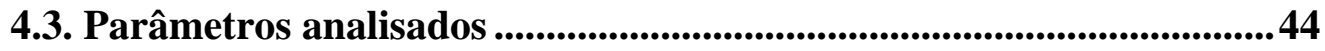

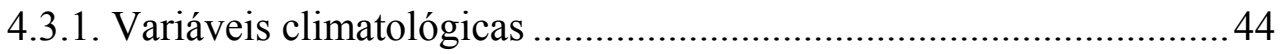

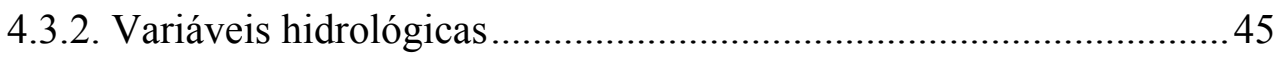

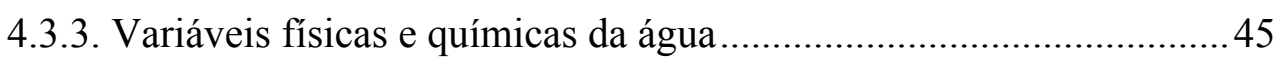

4.3.4. Variáveis biológicas da água..................................................... 46

4.4. Cálculo das Taxas de Eficiência de Remoção .....................................47

4.4.1. Taxa de Eficiência de Remoção Total............................................. 47

4.4.2. Taxa de Eficiência de Remoção Parcial........................................... 47

4.5. Interpretação dos dados.........................................................................47

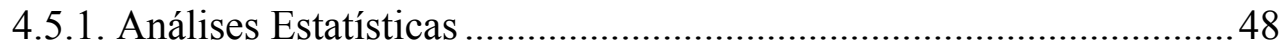

4.5.1.1. MANOVA e Testes de hipótese ............................................. 48

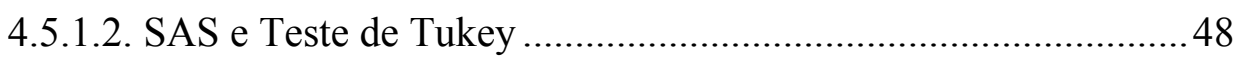

5. RESULTADOS E DISCUSSÃO........................................... 49

5.1. Variáveis climatológicas ..............................................................................55

5.1.1. Precipitação pluviométrica .............................................................52

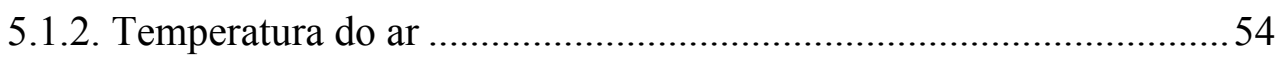

5.2. Variáveis hidrológicas................................................................55

5.3. Variáveis físicas e químicas da água................................................57

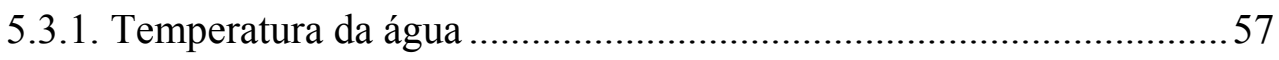

5.3.2. Oxigênio Dissolvido.........................................................................58

5.3.3. Potencial Hidrogeniônico ................................................................61

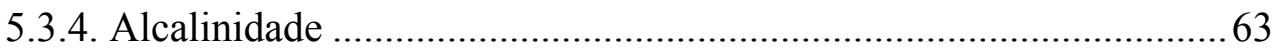




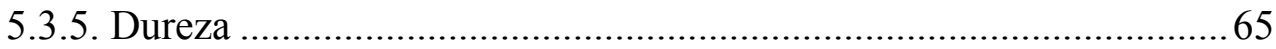

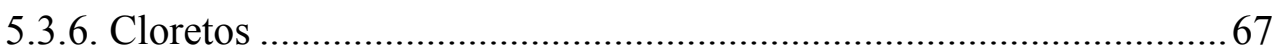

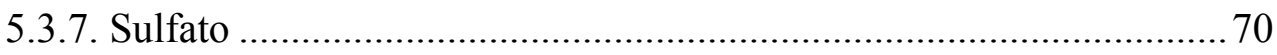

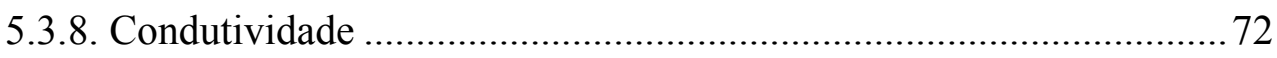

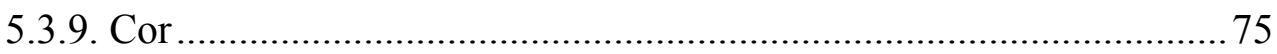

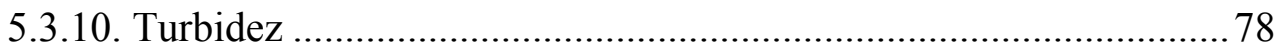

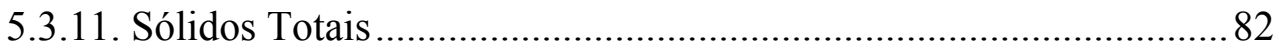

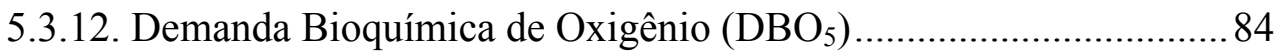

5.3.13. Demanda Química de Oxigênio (DQO) .......................................... 88

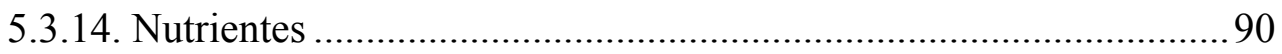

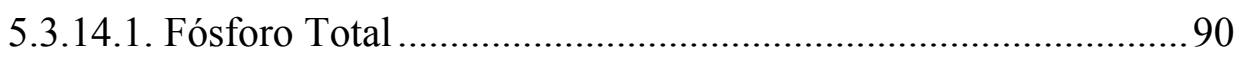

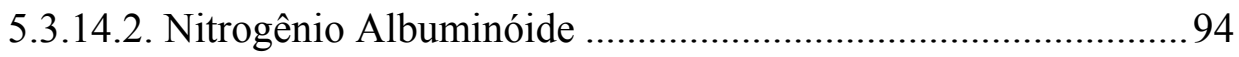

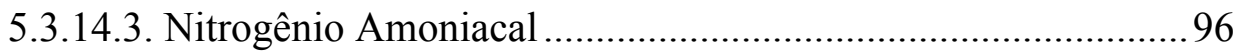

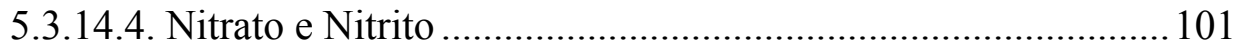

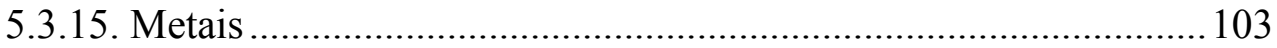

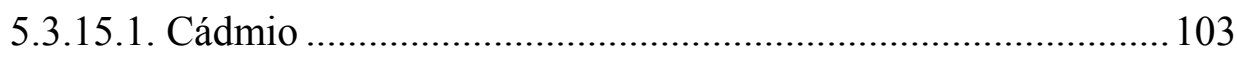

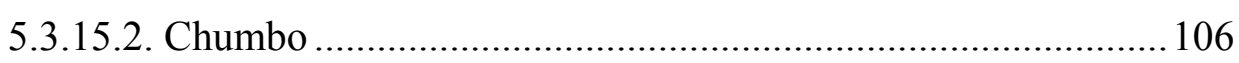

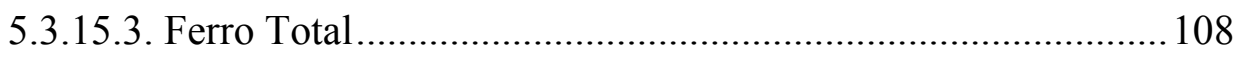

5.3.15.4. Manganês Total .................................................................... 112

5.3.15.5. Bário, Cobre, Cromo, Mercúrio, Prata e Zinco....................... 115

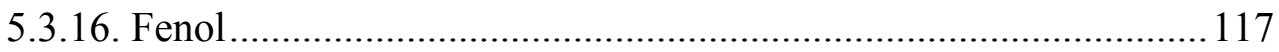

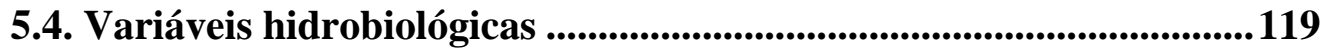

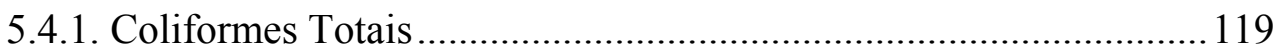

5.4.2. Coliformes Termotolerantes...................................................... 121

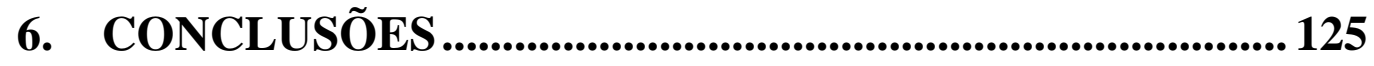

7. RECOMENDAÇÕES ...................................................... 127

REFERÊNCIAS BIBLIOGRÁFICAS.......................................... 130

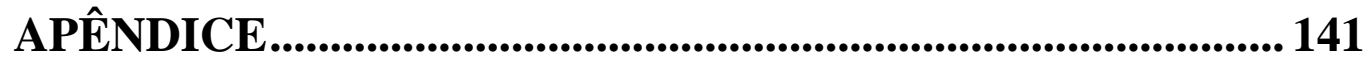




\section{LISTA DE FIGURAS}

Figura 1: Desenho esquemático de um canal com macrófitas flutuantes.

Figura 2: Desenho esquemático de um canal com macrófitas emergentes - fluxo superficial. 13

Figura 3: Desenho esquemático de um canal com macrófitas submersas. 13

Figura 4: Desenho esquemático da estrutura de um solo filtrante com fluxo descendente.

Figura 5: Desenho esquemático da estrutura de um solo filtrante com fluxo ascendente.

Figura 6: Plantas de áreas alagadas com habilidade de transportar oxigênio para o crescimento das raízes em substratos anaeróbios.

Figura 7: Tratamento de água para abastecimento público - ETA Analândia (SP) -6.480 hab.(15 L.s-1).

Figura 8: Tratamento de esgoto - ETE da Albrás Alumínio (PA). 13.000 hab $\left(67 \mathrm{~L} \cdot \mathrm{s}^{-1}\right)$.

Figura 9: Tratamento de efluente industrial - Usina Costa Pinto (Piracicaba/SP) 200L.s-1.

Figura 10: Folheto do Parque Ecológico do Tietê esquematizando a região do parque. 36

Figura 11: Canal de macrófitas aquáticas flutuantes e emergentes... .38

Figura 12: Plantas flutuantes (A-C) e emergentes (D) do canal de macrófitas...39

Figura 13: Foto do canal de macrófitas mostrando o consórcio aguapé, pistia e salvinia no ano de 2005 .

Figura 14: Módulo de solo filtrante.

Figura 15: Esquema do sistema combinado de alagados construído implantado em 2003, ilustrando os pontos de coleta.

Figura 16: Entrada do sistema de wetlands construídos

Figura 17: Saída do canal de macrófitas aquáticas flutuantes e emergentes e entrada do sistema de DHS

Figura 18: Saída do sistema de wetlands construídos 44 
Figura 19: Variação dos valores mensais de precipitação pluviométrica (mm) no Parque Estadual de Água Funda durante o ano de 2004 e 2005 e a média mensal histórica. 53

Figura 20: Variação dos valores de temperatura na hora da coleta e de temperatura média mensal do ar em 2004 e 2005. .54

Figura 21: Variação dos valores de temperatura da água durante o período de coleta de 2004 e 2005 nas etapas do sistema de alagados construídos. .57

Figura 22: Variação dos valores do oxigênio dissolvido da água durante o período de coleta de 2004 nas etapas do sistema de alagados construídos.

Figura 23: Variação dos valores do $\mathrm{pH}$ da água durante o período de coleta de 2004 e 2005 nas etapas do sistema de alagados construídos.

Figura 24: Variação dos valores de alcalinidade da água durante o período de coleta de 2004 nas etapas do sistema de alagados construídos. 63

Figura 25: Eficiência total e de cada uma das etapas do sistema de alagados construídos na remoção da alcalinidade durante o período de coleta de 2004 . 64

Figura 26: Variação dos valores da dureza da água durante o período de coleta de 2004 nas etapas do sistema de alagados construídos.

Figura 27: Eficiência total e de cada uma das etapas do sistema de alagados construídos na remoção da dureza durante o período de coleta de 2004. .66

Figura 28: Variação dos valores de cloretos da água durante o período de coleta de 2004 e 2005 nas etapas do sistema de alagados construídos. 68

Figura 29: Eficiência total e de cada uma das etapas do sistema de alagados construídos na remoção de cloretos durante o período de coleta de 2004 e 2005.

Figura 30: Variação dos valores de sulfato da água durante o período de coleta de 2004 nas etapas do sistema de alagados construídos. 70

Figura 31: Eficiência total e de cada uma das etapas do sistema de alagados construídos na remoção de sulfato durante o período de coleta de 2004 . 71

Figura 32: Variação dos valores da condutividade da água durante o período de coleta de 2004 e 2005 nas etapas do sistema de alagados construídos. 73

Figura 33: Eficiência total e de cada uma das etapas do sistema de alagados construídos na remoção da condutividade durante o período de coleta de 2004 e 2005.74

Figura 34: Variação dos valores de cor da água durante o período de coleta de 2004 e 2005 nas etapas do sistema de alagados construídos. 75 
Figura 35: Eficiência total e de cada uma das etapas do sistema de alagados construídos na remoção da cor durante o período de coleta de 2004 e 2005 . 76

Figura 36: Variação dos valores de turbidez da água durante o período de coleta de 2004 e 2005 nas etapas do sistema de alagados construídos.

Figura 37: Eficiência total e de cada uma das etapas do sistema de alagados construídos na remoção da turbidez durante o período de coleta de 2004 e 2005 . 80

Figura 38: Variação dos valores de sólidos totais da água durante o período de coleta de 2004 nas etapas do sistema de alagados construídos. 82

Figura 39: Eficiência total e de cada uma das etapas do sistema de alagados construídos na remoção de sólidos totais durante o período de coleta de 2004 .

Figura 40: Variação dos valores de $\mathrm{DBO}_{5}$ durante o período de coleta de 2004 nas etapas do sistema de alagados construídos. 85

Figura 41: Eficiência total e de cada uma das etapas do sistema de alagados construídos na remoção da $\mathrm{DBO}_{5}$ durante o período de coleta de 2004 . .86

Figura 42: Variação dos valores de DQO da água durante o período de coleta de 2004 e 2005 nas etapas do sistema de alagados construídos. 88

Figura 43: Eficiência total e de cada uma das etapas do sistema de alagados construídos na remoção da DQO durante o período de coleta de 2004 e 2005.

Figura 44: Variação dos valores de fósforo total da água durante o período de coleta de 2004 e 2005 nas etapas do sistema de alagados construídos. 91

Figura 45: Eficiência total e de cada uma das etapas do sistema de alagados construídos na remoção de fósforo total durante o período de coleta de 2004 e 2005...92

Figura 46: Variação dos valores de nitrogênio albuminóide da água durante o período de coleta de 2004 nas etapas do sistema de alagados construídos.

Figura 47: Eficiência total e de cada uma das etapas do sistema de alagados construídos na remoção de nitrogênio albuminóide durante o período de coleta de 2004 95

Figura 48: Variação dos valores de nitrogênio amoniacal da água durante o período de coleta de 2004 e 2005 nas etapas do sistema de alagados construídos. 97

Figura 49: Eficiência total e de cada uma das etapas do sistema de alagados construídos na remoção de nitrogênio amoniacal durante o período de coleta de 2004 e 2005 . .98

Figura 50: Eficiência total do sistema de alagados construídos na remoção de nitrato e nitrito durante o período de coleta de 2004. 
Figura 51: Variação dos valores de cádmio da água durante o período de coleta de 2004 nas etapas do sistema de alagados construídos.

Figura 52: Eficiência total e de cada uma das etapas do sistema de alagados construídos na remoção de cádmio durante o período de coleta de 2004 . 104

Figura 53: Variação dos valores de chumbo da água durante o período de coleta de 2004 nas etapas do sistema de alagados construídos. 106

Figura 54: Eficiência total e de cada uma das etapas do sistema de alagados construídos na remoção de chumbo durante o período de coleta de 2004 107

Figura 55: Variação dos valores de ferro total da água durante o período de coleta de 2004 e 2005 nas etapas do sistema de alagados construídos.

Figura 56: Eficiência total e de cada uma das etapas do sistema de alagados construídos na remoção de ferro total durante o período de coleta de 2004 e 2005 ..... 110

Figura 57: Variação dos valores de manganês total da água durante o período de coleta de 2004 e 2005 nas etapas do sistema de alagados construídos. 112

Figura 58: Eficiência total e de cada uma das etapas do sistema de alagados construídos na remoção de manganês total durante o período de coleta de 2004 e 2005 .

Figura 59: Variação dos valores de fenol da água durante o período de coleta de 2005 nas etapas do sistema de alagados construídos. A coleta no P2 em junho foi prejudicada.

Figura 60: Eficiência total e de cada uma das etapas do sistema de alagados construídos na remoção de fenol durante o período de coleta de 2005.

Figura 61: Variação dos valores de coliformes totais da água durante o período de coleta de 2004 nas etapas do sistema de alagados construídos.

Figura 62: Eficiência total e de cada uma das etapas do sistema de alagados construídos na remoção de coliformes totais durante o período de coleta de 2004 ...... 121

Figura 63: Variação dos valores de coliformes termotolerantes da água durante o período de coleta de 2004 nas etapas do sistema de alagados construídos 122

Figura 64: Eficiência total e de cada uma das etapas do sistema de alagados construídos na remoção de coliformes termotolerantes durante o período de coleta de 2004 


\section{LISTA DE TABELAS}

Tabela 1: Tipos de efluentes tratados com áreas alagadas construídas. 10

Tabela 2: Mecanismos de remoção de poluentes em alagados construídos. 18

Tabela 3: Características físicas do solo utilizado no sistema de alagados construídos (Outubro de 2003).

Tabela 4: Variáveis físicas e químicas analisadas e os métodos de determinação utilizados pela SABESP - Laboratório de Inorgânicos.

Tabela 5: Variação dos valores mensais de precipitação pluviométrica (mm) no Parque Estadual de Água Funda durante o ano de 2004 e 2005. Os valores em destaque correspondem aos meses de coleta.

Tabela 6: Variação dos valores de precipitação diária $(\mathrm{mm})$ durante o período de coleta no Parque Estadual de Água Funda. Os valores em destaque correspondem aos dias de coleta.

Tabela 7: Dados das variáveis hidrológicas nas diferentes etapas do sistema durante o período de estudo de 2004.

Tabela 8: Dados das variáveis hidrológicas nas diferentes etapas do sistema durante o período de estudo de 2005 . .56

Tabela 9: Resultado do Teste de Tukey para a variável temperatura da água ....58

Tabela 10: Resultado do Teste de Tukey para a variável oxigênio dissolvido ...59

Tabela 11: Resultado do Teste de Tukey para a variável $\mathrm{pH}$. 61

Tabela 12: Resultado do Teste de Tukey para a variável alcalinidade. 63

Tabela 13: Resultado do Teste de Tukey para a variável dureza. ........................66

Tabela 14: Resultado do Teste de Tukey para a variável cloretos. ......................68

Tabela 15: Resultado do Teste de Tukey para a variável sulfato........................ 71

Tabela 16: Resultado do Teste de Tukey para a variável condutividade .............73

Tabela 17: Resultado do Teste de Tukey para a variável cor.............................. 76

Tabela 18: Resultado do Teste de Tukey para a variável turbidez...................... 79

Tabela 19: Resultado do Teste de Tukey para a variável sólidos totais.............. 82

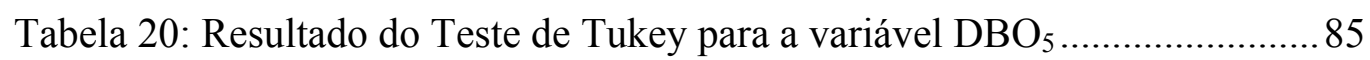

Tabela 21: Resultado do Teste de Tukey para a variável DQO..........................88

Tabela 22: Resultado do Teste de Tukey para a variável fósforo total ...............91 
Tabela 23: Resultado do Teste de Tukey para a variável nitrogênio albuminóide 95

Tabela 24: Resultado do Teste de Tukey para a variável nitrogênio amoniacal. 97

Tabela 25: Variação dos valores de nitrato na água durante o período de coleta de 2004 nas etapas do sistema de alagados construídos. 101

Tabela 26: Variação dos valores de nitrito na água durante o período de coleta de 2004 nas etapas do sistema de alagados construídos. 101

Tabela 27: Resultado do Teste de Tukey para a variável cádmio. 104

Tabela 28: Resultado do Teste de Tukey para a variável chumbo. 106

Tabela 29: Resultado do Teste de Tukey para a variável ferro total. 109

Tabela 30: Resultado do Teste de Tukey para a variável manganês total 112

Tabela 31: Variação dos valores de bário, cobre, cromo, mercúrio, prata e zinco na água durante o período de coleta de 2004 e 2005 nas etapas do sistema de alagados construídos. 116

Tabela 32: Resultado do Teste de Tukey para a variável fenol. 117

Tabela 33: Resultado do Teste de Tukey para a variável coliformes totais...... 120

Tabela 34: Resultado do Teste de Tukey para a variável coliformes termotolerantes 122 


\section{LISTA DE SÍMBOLOS E ABREVIAÇÕES}

CEDTA: Centro de Educação e Difusão de Tecnologias Ambientais

DAEE: Departamento de Águas e Energia Elétrica

DBO: Demanda bioquímica de oxigênio

DHS: Sistema de despoluição hídrica com solos filtrantes

DQO: Demanda química de oxigênio

ETA: Estação de tratamento de água

ETE: Estação de tratamento de esgoto

FBDS: Fundação Brasileira para o Desenvolvimento Sustentável

FEHIDRO: Fundação Estadual de Recursos Hídricos

IEA: Instituto de Ecologia Aplicada

MAFE: Canal de macrófitas aquáticas flutuantes e emergentes

PH: Potencial hidrogeniônico

PET: Parque Ecológico do Tietê

SABESP: Companhia de Saneamento Básico de São Paulo 


\section{RESUMO}

CUNHA, C.A.G. (2006). Análise da eficiência de um sistema combinado de alagados construídos na melhoria da qualidade das águas. Dissertação (Mestrado) - Escola de Engenharia de São Carlos, Universidade de São Paulo, São Carlos, 2006.

Este trabalho teve como objetivo avaliar a eficiência de um sistema combinado de alagados construídos, localizado no Parque Ecológico do Tietê em São Paulo, na melhoria da qualidade das águas. A estação de estudo é composta por um canal de decantação, um canal de macrófitas flutuantes (Eicchornia crassipes, Pistia stratioides, Salvinia auriculata) e emergentes (Typha angustifolia) de fluxo superficial, e duas células paralelas de solos filtrantes de fluxo vertical descendente cultivados com arroz (Oryza sativa). As coletas de água foram realizadas mensalmente, na entrada e saída de cada etapa do sistema, no período de fevereiro, março junho e julho de 2004 e de março a setembro de 2005. As variáveis físicas, químicas e biológicas da água foram medidas e taxas de eficiência de remoção parcial e total do sistema foram calculadas. A estação construída de alagados mostrou-se eficiente principalmente na remoção de sulfato $(52 \%)$, turbidez $(86 \%), \mathrm{DBO}_{5}(41-64 \%)$, fósforo total $(51-68 \%)$, nitrogênio albuminóide $(51,7 \%)$, nitrito $(77,8 \%)$ e nitrogênio amoniacal $(57-84 \%)$. Os canais de macrófitas apresentaram um alto desempenho de remoção média para maioria das variáveis analisadas no trabalho, contribuindo com a maior porção na taxa de remoção total do sistema. Durante o período de estudo, provavelmente devido à falta de manejo do sistema, observou-se a volta dos nutrientes assimilados pelas macrófitas para a coluna d'água $(\mathrm{N}, \mathrm{P}, \mathrm{Fe})$ com a decomposição das plantas e condições de anaerobiose nos solos filtrantes. Esses fatores, juntamente com a presença dos animais do parque atraídos pelo arroz, contribuíram com o baixo desempenho do canal de macrófitas e dos solos filtrantes na remoção de cor, turbidez, ferro total e coliformes em alguns meses de coleta. Para a maioria das variáveis analisadas, a água tratada pelo sistema de alagados construídos alcançou os limites e padrões estabelecidos pela Resolução CONAMA 357/2005 para águas doces de classe 2 (BRASIL, 2005). Contudo, em função dos dados obtidos, não se pode enquadrar totalmente o efluente, embora seja esperado que com a estabilização do sistema e um manejo adequado, a água tratada consiga atingir as características exigidas e possa ser enquadrada em águas doces de classe 2.

Palavras - chave: ecotecnologia, alagados construídos, canal de macrófitas, sistema DHS, tratamento de água, Parque Ecológico do Tietê 


\begin{abstract}
CUNHA, C.A.G. (2006). Assessment of efficiency of combined constructed wetlands system for water quality improvement. M.Sc. Dissertation - Escola de Engenharia de São Carlos, Universidade de São Paulo, São Carlos, 2006.

The aim of this work was evaluate the efficiency of combined constructed wetlands, located in the Tiete Ecological Park in São Paulo, in water quality improvement. The station consists of a settling channel, one free-floating (Eichhornia crassipes, Salvinia auriculata, Pistia stratiotes) and rooted emergent macrophyte-based system (Typha angustifolia) with surface flow and two cells of vertical flow filter soils in parallel, planted with rice (Oryza sativa). The water samples were collected monthly at the inlet and outlet of each step of the system, in the period of February, March June and July of 2004 and of March to September of 2005. The physical, chemical and biological variables of the water were measured and efficiency rates of the system were made. The constructed wetlands system mainly showed efficient removal rates in sulphate $(52 \%)$, turbidity $(86 \%)$, BDO $(41-64 \%)$, total phosphorus $(51-68 \%)$, organic nitrogen $(51,7 \%)$, nitrite $(77,8 \%)$ and ammonia nitrogen $(57-84 \%)$. The settling channel and macrophyte-based system presented a high removal performance for most of the variables analyzed in the work, contributing with the largest portion in the total removal rate of the system. During the study period, probably due to the lack of system management, the return of nutrients previously uptaken $(\mathrm{N}, \mathrm{P}, \mathrm{Fe})$ by macrophytes for the water column was observed with the decay of aging plants and anaerobic conditions in the HDS system. Those factors, added with the presence of the park's animals attracted for the rice, contributed with the low performance of macrophyte-based and HDS system in the removal of color, turbidity, total iron and coliforms in some months of collection. For most of the analyzed variables, the water treated by the constructed wetlands system reached the limits and patterns established by the Resolution CONAMA 357/2005 for fresh water of class 2 (BRAZIL, 2005). However, due to the obtained data, the treated water cannot be totally classified as class 2 , although it is expected that with the stabilization of the system and appropriate handling, the treated water reach the demanded characteristics and can be classified in fresh water of class 2 .
\end{abstract}

Keywords: ecotechnology, constructed wetlands, macrophyte-based system, HDS system, water treatment, Tiete Ecological Park. 


\section{INTRODUÇÃO}

A água doce é um recurso natural escasso e de vital importância. Ela está relacionada tanto com a própria sobrevivência das espécies, quanto com a realização de atividades e serviços que vão atender os seres vivos em suas necessidades, desde as mais básicas, como consumo próprio e alimentação, até as menos nobres, como descarga de resíduos pelos homens.

Em decorrência de sua importância, tanto em relação a seus diversos usos quanto à manutenção de sua qualidade e quantidade, os recursos hídricos são considerados bens comuns, que devem ser geridos de forma integrada, garantindo, desta forma, aproveitamento otimizado com mínimo de conflitos (CALIJURI \& BUBEL, 2006).

Por estar sempre tão intimamente ligada a todas as atividades humanas e por sua abundância no planeta, a água doce sempre foi largamente explorada e desperdiçada. Hoje, além de determinadas regiões sofrerem com a falta de água, a qualidade da mesma está afetada. Apesar da existência de uma legislação em vigor, o que se observa, devido ao grande crescimento populacional e ao intenso desenvolvimento industrial, comercial e agrícola, é uma poluição dos recursos hídricos tanto superficiais quanto subterrâneos pela descarga de efluentes industriais e domésticos, percolados de aterro sanitário, atividades mineradoras e carreamento de fertilizantes das áreas agrícolas, dentre outros.

O não tratamento destes resíduos, bem como a sua destinação incorreta, vem contribuindo de forma marcante para o agravamento dos problemas ambientais e de saúde da população humana. Diante disso, muitos trabalhos estão sendo desenvolvidos na busca de tecnologias capazes de minimizar a toxicidade dos efluentes antes de serem lançados nos corpos receptores, tratar água para o abastecimento público e recuperar os ecossistemas já impactados pelas atividades antrópicas.

Um tipo de sistema que vem sendo estudado é o de áreas alagadas. Os alagados têm recebido descargas de águas poluídas em numerosos tipos de situações no passar dos anos, mas somente recentemente foram reconhecidos como um sistema de tratamento potencialmente eficiente e com um custo relativamente baixo (SMITH, 1989).

O interesse pelos alagados deve-se a maior confiança depositada, atualmente, nos sistemas que necessitam de uma baixa demanda energética e um menor uso de processos químicos intensivos (BASTIAN \& HAMMER, 1993). Os poluentes são 
removidos através de uma combinação de processos físicos, químicos e biológicos incluindo sedimentação, precipitação, adsorção de partículas no solo, assimilação pelo tecido da planta e transformação bacteriana (BRIX, 1993).

Apesar da potencialidade dos alagados naturais em controlar o fluxo de nutrientes e poluentes, esforços conservacionistas inibiram o uso destas áreas para propósitos aplicados, uma vez que há ainda muito para se estudar sobre as possíveis conseqüências do seu uso em larga escala. Estes e outros fatores levaram ao rápido desenvolvimento de estudos em áreas alagadas construídas para o tratamento das águas residuárias (HAMMER \& BASTIAN, 1989).

Os trabalhos iniciados nesta área foram estimulados pela esperança de simular e melhorar as propriedades ótimas de remoção dos alagados naturais. Desta forma, os alagados construídos são projetados para utilizar os princípios básicos de remoção de poluentes que ocorrem em um alagado natural, só que com um maior grau de controle, uma vez que há uma definição da composição do substrato e do tipo de vegetação, seleção do local, controle hidráulico e uma escolha do tempo de retenção (BRIX, 1993).

As técnicas de alagados construídos foram bastante desenvolvidas nos últimos anos e podem ser divididas de acordo com o tipo de macrófita e tipo de fluxo hídrico utilizados. A escolha do sistema é feita a partir das características do efluente a ser tratado, da eficiência de remoção final desejada, do interesse de utilização da biomassa a ser produzida e do próprio interesse paisagístico (SALATI, 2000).

Esta ecotecnologia tem sido amplamente utilizada em vários países como solução apropriada para melhoria da qualidade das águas de rios e lagos, tratamento de efluentes domésticos e industriais, tratamento de águas de escoamento urbano e agrícola, efluente de mineradoras e percolados de aterro sanitário.

De acordo com Calijuri e Bubel (2006), a pressão sobre os recursos hídricos torna essencial a implantação de ações de monitoramento, pesquisa e gerenciamento, possibilitando, assim, transferência contínua da base científica para a aplicação.

Visando, portanto, um maior conhecimento da utilização de alagados construídos como forma de tratamento para melhoria da qualidade dos recursos hídricos no Brasil, este trabalho baseou-se no monitoramento da eficiência de um sistema combinado de alagados construídos, localizado na região do Parque Ecológico do Tietê em São Paulo, na remoção de determinados constituintes da água.

A técnica de alagados construídos é uma ótima opção para o tratamento de diferentes tipos de efluentes no Brasil, uma vez que apresenta baixo custo de 
implantação e consumo de energia, simplicidade de instalação e operação, não há geração de lodo e é um processo que não necessita de substâncias químicas adicionais. Segundo Salati (1998), o aprofundamento dos conhecimentos científicos com relação aos alagados poderá permitir que os projetos sejam aperfeiçoados e, desta forma, sua função de melhoria da qualidade da água otimizada e menores investimentos utilizados.

\section{OBJETIVOS}

O objetivo principal desta pesquisa foi investigar o desempenho de um sistema combinado de alagados construídos, localizado no Parque Ecológico do Tietê em São Paulo, na melhoria da qualidade das águas.

Para alcançar esse objetivo, essa pesquisa foi fundamentada:

- No comportamento de variáveis físicas, químicas e biológicas no alagado construído durante o período inicial do sistema e após um ano de funcionamento;

- Na avaliação da eficiência global e de cada etapa de tratamento da estação com abordagem de alguns aspectos dos processos físicos, químicos e biológicos que atuam na depuração de poluentes e na redução de indicadores de patógenos;

- No Enquadramento do efluente no padrão de águas doces de classe 2.

\section{REVISÃO BIBLIOGRÁFICA}

\section{1. Áreas Alagadas Naturais}

O termo wetlands (do inglês) ou áreas alagadas é utilizado para caracterizar vários ecossistemas naturais que ficam parcial ou totalmente inundados durante o ano (SALATI, 2000).

Uma definição para as áreas alagadas foi proposta por Cowardin ${ }^{1}$ e colaboradores (1979) conforme citado por Hammer e Bastian (1989):

As áreas alagadas são áreas de transição entre sistemas aquáticos e terrestres onde a água é o fator dominante do desenvolvimento dos solos e da comunidade biológica associada, e onde, ao menos periodicamente, o nível das águas está na ou próximo da superfície, ou o solo é coberto por uma camada rasa de água.

${ }^{1}$ COWARDIN, L.M; CARTER, F.C; GOLET, F.C; LAROE, E.T. (1979). Classification of Wetlands and Deepwater Habitats of the United States. U.S. Department of Interior FWS/OBS 79/31. 
Segundo este mesmo autor, os alagados devem ter um ou mais dos seguintes atributos:

- pelo menos periodicamente, essas áreas são habitat de hidrófitas;

- o substrato constitui-se principalmente de solos hidromórficos pobremente drenados;

- o substrato não é solo propriamente dito (neste caso são sedimentos pobremente consolidados) e se encontra saturado ou coberto por uma rasa camada de água em algum período do ano (COWARDIN ${ }^{2}$ et al., 1979 apud HAMMER \& BASTIAN, 1989).

No entanto, esta definição não engloba algumas características dos ecossistemas tropicais, rios e planícies de inundação (SALATI, 2000). A definição ecológica para áreas alagadas, segundo Junk (1980), é:

Áreas alagadas são áreas periodicamente inundadas por uma enchente lateral de rios e lagos e/ou pela precipitação direta ou por águas subterrâneas, mudando o ambiente físico-químico de tal forma que a biota responde através de adaptações morfológicas, anatômicas, fisiológicas, fenológicas e/ou etológicas, resultando em estruturas características da comunidade.

No senso geológico, as áreas alagadas naturais são componentes efêmeros da paisagem, altamente dependentes de distúrbios do tempo, forças tectônicas ou fenômenos localizados como inundações e secas diárias ou anuais, fogo e tempestades (HAMMER \& BASTIAN, 1989).

As áreas alagadas estão entre os ecossistemas mais produtivos existentes na Terra e são capazes de transformar poluentes comuns, que ocorrem em águas residuárias, em produtos inofensivos ou em nutrientes essenciais utilizados para uma produtividade biológica adicional. Tais transformações são conduzidas por energias ambientais naturais (sol, vento, solo), plantas e animais, e por isso, o tratamento utilizando esse sistema não necessita de substâncias químicas adicionais (KADLEC \& KNIGHT, 1996).

As wetlands naturais são facilmente reconhecidas como as várzeas dos rios, os igapós na Amazônia, os pântanos, os manguezais, os banhados e as formações lacustres de baixa profundidade, dentre outros (SALATI, 1998). Estes sistemas têm importantes funções dentro dos ecossistemas onde são inseridos, entre as quais se destacam:

${ }^{2}$ COWARDIN, L.M; CARTER, F.C; GOLET, F.C; LAROE, E.T. (1979). Classification of Wetlands and Deepwater Habitats of the United States. U.S. Department of Interior FWS/OBS 79/31. 
- regular os fluxos de água;

- modificar e melhorar a qualidade das águas, funcionando como filtros naturais que purificam a água à medida que a mesma escoa;

- controlar a erosão, evitando o assoreamento dos rios;

- proteger à biodiversidade, como área de refúgio da fauna terrestre;

- fornecer o suprimento de alimentos para toda a cadeia alimentar;

- ser um local para reprodução e alimentação da fauna aquática (SALATI, 2000).

Os primeiros estudos realizados em terras úmidas no Brasil decorreram das observações feitas nas várzeas amazônicas. Constatou-se nestes estudos que as características das águas, que cobriam os lagos existentes ao longo do Rio Solimões no período de cheias, apresentavam modificações aos saírem dos lagos nos períodos de vazantes (SALATI, 2000).

Segundo Hammer (1993), a melhoria da qualidade das águas em regiões alagadas é dependente da própria coluna d’água, do substrato, da vegetação (macrófitas), da população de microrganismos associada a estes elementos e dos animais vertebrados e invertebrados.

A sociedade humana vem utilizando indiretamente, há milhares de anos, as terras úmidas naturais para purificação da água. Essa prática, de acordo com a Agência de Proteção Ambiental dos Estados Unidos (USEPA), vem transformando e até mesmo destruindo muitas wetlands por todo o mundo. Tais transformações se devem principalmente à contaminação química e ao excesso de nutrientes, sedimentos e/ou poluentes (USEPA, 2005).

Além da utilização dos alagados como alternativa para o tratamento de águas residuárias, outros fatores (naturais e/ou antrópicos) podem ser citados como responsáveis pela sua degradação: drenagem, canalização e represamento dos rios, introdução de espécies não-nativas, escoamento, construções, erosões, secas e aumento no nível da água, dentre outros. Como conseqüência, tem-se observado um aumento dos danos causados por enchentes e secas (USEPA, 2005).

Preocupados com a devastação destes ecossistemas foi ratificada e aprovada em 1971, a Convenção de Ramsar, que é um tratado intergovernamental com o objetivo principal de cooperação internacional para a conservação e preservação de zonas úmidas. Ele representa o primeiro tratado global sobre conservação de áreas ambientais. 
Este tratado conta atualmente com a participação de 119 países signatários em todo o mundo e possui aproximadamente 1.000 sítios de preservação espalhados pelos continentes, cobrindo cerca de 73 milhões de hectares de zonas úmidas (Ministério da Ciência e Tecnologia, 2005).

O Brasil ratificou a convenção em 24 de setembro de 1993 e é considerado o quarto país do mundo em superfície de áreas úmidas, com sete áreas de preservação (MCT, 2005). De acordo com a SABESP/GEOTEC 3 (1998) citado por Beccato (2004), cerca de $400.00 \mathrm{~km}^{2}$ ou $6,3 \%$ do território nacional é recoberto por áreas alagadas naturais sendo as mais expressivas: o Pantanal Mato-grossense, a região Amazônica, as áreas inundadas formadas pelo Rio Araguaia e pelo rio Paraguai, além dos manguezais nas regiões costeiras.

Brix (1993) e Wetzel (1993) afirmam que embora melhorias significativas na qualidade das águas existam como resultado do fluxo por áreas alagadas naturais, a extensão da capacidade do tratamento é desconhecida. $\mathrm{O}$ desempenho pode mudar ao longo do tempo como conseqüência de alterações na composição das espécies e o próprio acúmulo de poluentes no alagado.

No Brasil ainda são poucos os trabalhos publicados com relação às áreas alagadas naturais e o seu desempenho na remoção de poluentes. Dentre os estudos existentes, as linhas de pesquisa em sua maioria se concentram na avaliação econômica dos alagados, na observação de sua eficiência na remoção de determinadas variáveis e propostas de manejo para aperfeiçoá-los como filtros de purificação da água.

Figueiroa (1996) fez um levantamento sobre como avaliar economicamente os ambientes naturais e teve como objeto de estudo as áreas alagadas da Represa do Lobo em Itirapina (SP). Neste trabalho, ele demonstrou que esses ecossistemas são de grande importância e que geram uma série de benefícios sociais e econômicos, entre eles recreação e agricultura.

Uma proposta de manejo para a área alagada natural do Rio Atibaia, visando à melhoria da qualidade da água do reservatório de Salto Grande, foi elaborada por Lopes-Ferreira (2000). Durante seus estudos, foi verificado que o período de seca é o mais crítico para a qualidade da água com relação ao nitrogênio $(\mathrm{N})$ e fósforo $(\mathrm{P})$, uma vez que a maior parte do rio segue por seu leito principal sem passar pela área alagada.

3 SABESP/GEOTEC (1998). Wetlands - O uso de áreas alagáveis para tratamento de efluentes. Contrato AM n5626/98. Relatório Parcial - Nov - 75p. 
De acordo com suas observações, a autora propôs estratégias de manejo para otimizar as propriedades de purificar a água do alagado natural.

Com relação à remoção de variáveis da água, pode-se citar o trabalho de Anjos (2003), que avaliou a eficiência de uma zona alagadiça, que ocorre nas dependências de uma usina, como medida de controle da contaminação proveniente de um barramento de escória contaminada por metais pesados na Bahia. Um outro estudo foi realizado por Andrade (2005) visando analisar a atuação da várzea do Ribeirão Parelheiros, que recebe água de transposição da Represa Billings para a Represa do Guarapiranga, na melhoria da qualidade das águas que afluem à represa.

Benassi (no prelo) vem desenvolvendo um trabalho para avaliar a dinâmica espaço-temporal de um sistema de áreas alagadas naturais, em uma microbacia no Vale do Ribeira do Iguape, na melhoria da qualidade da água, após o lançamento de um efluente da estação de tratamento de esgoto. A autora observou que as variáveis físicas e químicas da água apresentaram grande amplitude de variação temporal e sazonal, principalmente em relação aos nutrientes na estação chuvosa, quando havia conectividade do rio com o sistema de alagados.

\section{2. Áreas Alagadas Construídas}

Os alagados construídos são ecossistemas artificiais que utilizam os princípios básicos de modificação da qualidade da água das várzeas naturais (SALATI, 2000). No entanto, segundo Marques (1999), há uma otimização das propriedades relativas às funções de ciclagem de nutrientes, remoção de matéria orgânica, princípios ativos e metais.

Do ponto de vista prático, estes sistemas podem ser projetados com um maior grau de controle: definição da composição do substrato (pode-se melhorar a condutividade hidráulica do sistema) e do tipo de vegetação, seleção do local, controle hidráulico e tempo de retenção (BRIX, 1993).

Segundo Kadlec e Knight (1996), o principal objetivo do sistema de alagados construídos é a melhoria da qualidade da água, seguido por objetivos secundários, tais como a produção fotossintética, a produção de energia, a recreação e educação ambiental.

O uso de wetlands construídas teve sua origem no Instituto Max Planck, em Plon na Alemanha em 1952 (BASTIAN \& HAMMER, 1993). Os pesquisadores estudaram a 
remoção de fenol utilizando uma vegetação de áreas alagadas, o junco principalmente. Tal trabalho levou ao desenvolvimento de um projeto denominado Processo do Instituto Max Plank ou Sistema Seidel, com valas retangulares revestidas de concreto e parcialmente preenchidas com cascalho.

Estes sistemas assim como os alagados naturais têm como componentes principais:

- o meio suporte (argila, areia, cascalho ou outro) com uma boa condutividade hidráulica;

- as plantas aquáticas adaptadas a substratos anaeróbios saturados por água;

- a coluna d água (fluindo internamente ao substrato ou sobre sua superfície);

- a presença de uma série de animais vertebrados e invertebrados;

- a comunidade microbiana adaptada ou tolerante a condições aeróbias e anaeróbias (HAMMER \& BASTIAN, 1989; FARAHBAKHSHAZAD \& MORRISON apud NOGUEIRA 2003).

Segundo Farahbakhshazad e Morrison ${ }^{4}$ (1998) apud Nogueira (2003), a seleção do substrato depende do tipo de efluente (domiciliar, industrial, percolados de aterro sanitário) e do regime hidráulico escolhido (fluxo superficial ou subsuperficial). Os solos compostos por uma mistura de areia, silte e argila são adequados para o crescimento de grande parte das plantas.

Além disso, outras características como a textura e o teor de matéria orgânica são desejados nestes sistemas. Tais propriedades são adequadas para permitir a retenção da água e difusão de gases, para promover a retenção e liberação de nutrientes (alta capacidade de troca catiônica), e também, para permitir o desenvolvimento das raízes (KADLEC, 1997).

Com relação as macrófitas, alguns critérios visando o sucesso do sistema devem ser considerados. Segundo Marques (1999) estimula-se a utilização de espécies locais e não exóticas, e também tolerantes a prolongados períodos de submergência ou permanência em substrato saturado a maior parte do ano. As espécies do gênero Typha e Scirpus tendem a dominar em sistemas de alagados construídos em função da resposta a concentração de nutrientes (estresse ambiental).

${ }^{4}$ FARAHBAKHSHAZAD, N.; MORRISON, G.M (1998). Subsurface macrophyte systems in wastewater treatment. Vatten, v.54, p.41-51. 
A eficiência de um sistema de alagados construídos está diretamente relacionada à percentagem de nutrientes e substâncias químicas absorvidas, transformadas ou decompostas pelo ecossistema de alagados.

O termo eficiência ou remoção tem sido utilizado, principalmente, com relação aos wetlands construídos para se determinar quais projetos construtivos de alagados conseguem uma maior retenção de substâncias, ou quando se quer fazer uma comparação desta ecotecnologia com os demais sistemas de tratamento convencionais. São encontrados trabalhos verificando, por exemplo, a remoção de traços de metais em drenagem ácida (EGER et al., 1993); a remoção de DBO, DQO e sólidos suspensos em efluentes domésticos (SOLANO; SORIANO \& CIRIA, 2004) e a remoção de nitrogênio e fósforo em sistemas de alagados construídos combinados (HUETT et al., 2005).

A aplicação do termo de remoção como um processo inerente à retenção/transformação de nutrientes foi aplicado na $7^{\mathrm{a}}$ Conferencia Internacional de Sistemas de Alagados no Controle da Poluição das águas realizado na Flórida em 2000 (REDDY \& KADLEC 5 , 2000 apud ANJOS, 2003).

Um levantamento realizado por Knight e Kadlec (2000) indicou a existência de mais de 6000 wetlands construídos para o tratamento de resíduos domésticos na Europa, e de mais de 1000 para o tratamento de efluentes industriais e domésticos na América do Norte. Segundo os autores, no Brasil, na África, na Ásia e na Austrália, o número de sistemas construídos vem aumentando, mas principalmente para o polimento de águas residuais.

Os diferentes tipos de efluentes tratados com alagados artificiais podem ser visualizados na tabela 1 .

5 REDDY, K.R; KADLEC, R.H. (2000). Wetland Systems for Water Pollution Control 2000. Water Science and Technology, London, v.44, n11-12, 427p. 
Tabela 1: Tipos de efluentes tratados com áreas alagadas construídas.

\begin{tabular}{|c|c|c|}
\hline & PO DE EFLUENTE & AUTORES \\
\hline Industrial & $\begin{array}{l}\text { - estágio de polimento } \\
\text { - indústrias de papel e celulose } \\
\text { - refinarias de petróleo } \\
\text { - indústrias alimentícias }\end{array}$ & $\begin{array}{l}\text { FERREIRA et al, 2001; SOUSA et al. } 2000 . \\
\text { THUT, 1989; HAMMER et al.,1993 } \\
\text { JI et al., 2002. } \\
\text { VRHOVSEK et al.1996 }\end{array}$ \\
\hline Doméstico & $\begin{array}{l}\text { - pequenas vilas } \\
\text { - municípios }\end{array}$ & $\begin{array}{l}\text { SOLANO et al., 2004, SALATI et al., } 1999 . \\
\text { BRIX, 1994; WITHAR, 1993; SALATI et al., } 1999\end{array}$ \\
\hline $\begin{array}{l}\text { Deflúvio } \\
\text { superficial }\end{array}$ & $\begin{array}{l}\text { - agropecuária } \\
\text { - urbano }\end{array}$ & $\begin{array}{l}\text { COSTELLO, 1989; NEWMAN et al., } 2000 . \\
\text { MEIORIN, 1989; SILVERMAN, } 1989 .\end{array}$ \\
\hline \multicolumn{2}{|c|}{ Percolados de aterro sanitário } & CAMPOS, 2002; VALENTIM, 2003 \\
\hline \multicolumn{2}{|c|}{ Viveiros e sementeiras } & HUNTER et al., 1993; HUETT et al., 2005 \\
\hline \multicolumn{2}{|c|}{ Mina } & EGER et al., 1993; HOWARD et al., 1989 \\
\hline
\end{tabular}

O período inicial de um novo sistema de alagado construído, segundo Kadlec e colaboradores (2000), é um período crítico. Este início do sistema inclui a seleção e o transplante das plantas para o sistema e é um momento no qual o solo, as plantas e os microrganismos se ajustam às condições hidrológicas do alagado construído. Como todo sistema vivo, as wetlands podem tolerar melhor as mudanças se for permitido um tempo para sua estabilização. Alguns processos de remoção requerem somente curtos períodos para se estabilizarem, mas outros podem exigir meses ou anos para alcançar estabilidade.

As áreas alagadas artificiais construídas requerem alguns meses para o estabelecimento da vegetação e do biofilme, e de 1-2 anos para o desenvolvimento da camada superficial do solo composta por detritos orgânicos (litter) em sistemas de fluxo superficial. A lixiviação e adsorção de alguns constituintes também podem levar algum tempo (um ano ou mais) para acontecer se a opção por um alagado de fluxo subsuperficial tiver sido escolhida.

\subsubsection{Tipos de áreas alagadas construídas}

Os tipos de alagados construídos tratados neste trabalho foram baseados no sistema de classificação de Brix (1993), que os separou de acordo com o tipo de macrófita utilizada:

a) sistemas que utilizam plantas aquáticas flutuantes;

b) sistemas que utilizam plantas aquáticas emergentes;

c) sistemas que utilizam plantas aquáticas submersas;

d) sistemas combinados. 
Um outro tipo de sistema denominado DHS (Despoluição Hídrica com Solos Patente Pi 850.3030) foi projetado por Enéas Salati em 1987. Tal sistema sofreu algumas modificações para aumentar sua eficiência e para ser utilizado em situações especiais de águas muito poluídas, ficando conhecido como sistema DHS de fluxo ascendente (SALATI FILHO; MANFRINATO \& SALATI, 1996).

O alagado construído de estudo é um sistema combinado com canal de macrófitas flutuantes e emergentes de fluxo superficial, e três módulos de solos filtrantes.

\subsubsection{Sistemas que utilizam plantas aquáticas flutuantes}

As macrófitas flutuantes formam um grande grupo de plantas e são normalmente utilizadas em projetos com canais relativamente rasos, longos e estreitos (Fig. 1). De acordo com o Instituto de Ecologia Aplicada (IEA), tais canais podem conter apenas uma espécie de planta ou uma combinação (IEA, 1997). A ação depuradora destes sistemas ocorre devido à absorção de nutrientes e metais pelas macrófitas; pelo transporte de oxigênio para a rizosfera e pela ação de microrganismos associados ali presentes. A espécie mais estudada é a Eicchornia crassipes, conhecida como aguapé, devido a sua capacidade de resistir a águas altamente poluídas, com grande variação de nutrientes, $\mathrm{pH}$, substâncias tóxicas, metais pesados e variações de temperatura (SALATI, 2000).

A alta capacidade de reprodução e de crescimento associada às características citadas anteriormente permitem que o aguapé se prolifere rapidamente em locais com elevado grau de contaminantes tóxicos e/ou eutrofizantes (SALATI, 2000). Brix (1993) ressalta que essas características são fundamentais para uma boa eficiência de tratamento, já que o ecossistema aquático propicia um ambiente ótimo tanto para a degradação da matéria orgânica como para processos de remoção de nutrientes.

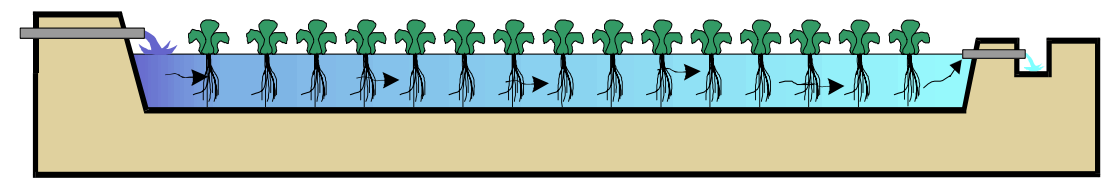

Figura 1: Desenho esquemático de um canal com macrófitas flutuantes. Fonte: SALATI, 2000. 


\subsubsection{Sistemas que utilizam plantas aquáticas emergentes}

Estes alagados utilizam plantas que se desenvolvem tendo o sistema radicular preso ao sedimento, e o caule e as folhas parcialmente submersos. Dependendo da espécie considerada, a profunda penetração do sistema radicular permite a exploração de uma grande área de sedimento (BRIX, 1993; SALATI, 2000). As espécies típicas de macrófitas aquáticas emergentes são conhecidas de forma genérica pelo nome de juncos, sendo as mais utilizadas: Phragmites australis, Typha latifolia e Scirpus lacustris (SALATI, 2000).

Todas as espécies são morfologicamente adaptadas para se desenvolverem em sedimentos inundados, uma vez que possuem um sistema lacunar interno (50-70\% do volume total) que propicia a transferência do oxigênio para o sistema radicular (SALATI, 2000). Parte desse oxigênio pode ainda ser liberada para a área da rizosfera criando condições para o estabelecimento da biota microbiana e também para oxidação do sedimento (BRIX, 1993).

Existem três tipos de sistemas com macrófitas emergentes que variam de acordo com o tipo de fluxo hídrico utilizado: superficial, subsuperficial horizontal e fluxo vertical. Cada tipo de fluxo proporciona um grau diferente de interação do efluente com a raiz, rizomas e componentes do sedimento colonizados pela biota microbiana (SALATI, 2000).

No canal de fluxo superficial, o efluente fica exposto à atmosfera. Esta técnica é uma das mais antigas de alagados construídos, com mais de trinta anos de operação na Holanda (GREINER \& DE JONG 61984 apud BRIX, 1993). Segundo Salati (2000), um projeto típico deste sistema consiste em um canal com 3 - 5 metros de largura e da ordem de 100 metros de comprimento, em que as águas poluídas fluem horizontalmente sobre o sedimento (Fig.2). O solo é cultivado com juncos e uma lâmina de água de 10$40 \mathrm{~cm}$ é mantida sobre a superfície do solo (BRIX, 1993).

${ }^{6}$ GREINER, R.W; DE JONG, J. (1984). The use of Marsh Plants for the Treatment of Wastewater in Áreas Designated for Recreation and Tourism, RIPJ Report no. 225. Lelystad, The Netherland. 


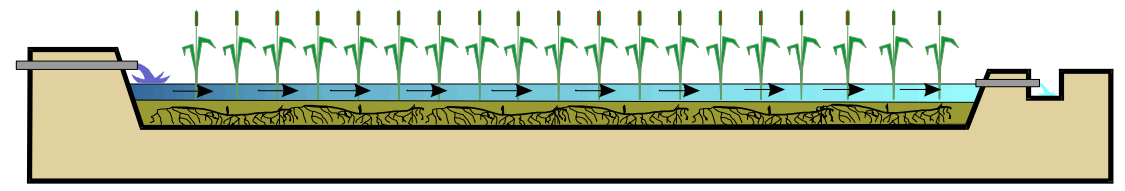

Figura 2: Desenho esquemático de um canal com macrófitas emergentes - fluxo superficial. Fonte: SALATI, 2000.

\subsubsection{Sistemas que utilizam plantas aquáticas submersas}

As macrófitas submersas, assim como o próprio nome diz, têm seus tecidos fotossintéticos totalmente submersos. Essas plantas são capazes de assimilar nutrientes de águas poluídas, mas só crescem bem em águas oxigenadas, e por isso não podem ser utilizadas no tratamento de águas com alta concentração de matéria orgânica. A utilização destas macrófitas é feita em canais estreitos e longos (Fig. 3), com profundidade variável (SALATI, 2000).

Os trabalhos com utilização desta técnica estão ainda em estágio experimental, especialmente com o uso de espécies como: egéria (Egeria densa), elodea (Elodea canadensis e E. nutallii), ceratófilo (Ceratphyllum demersum) e Hydrilla verticillata que são as mais promissoras. Sua utilização tem sido recomendada para os estágios finais de sistemas de combinados (BRIX, 1993).

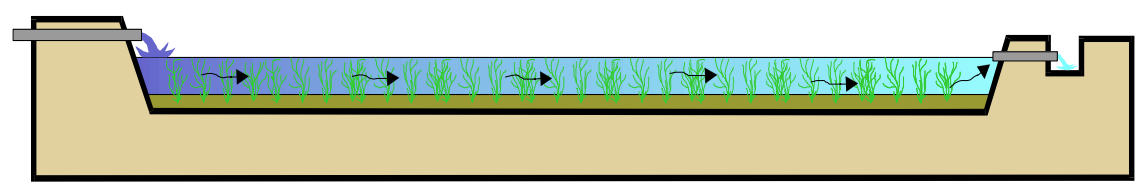

Figura 3: Desenho esquemático de um canal com macrófitas submersas. Fonte: SALATI, 2000.

\subsubsection{Sistemas de despoluição hídrica com solos filtrantes (DHS)}

O sistema DHS é constituído por camadas superpostas de brita, pedrisco e solo cultivado com arroz. As dimensões dos módulos de solos filtrantes, bem como a espessura da camada do solo, variam de acordo com o efluente a ser tratado e com a

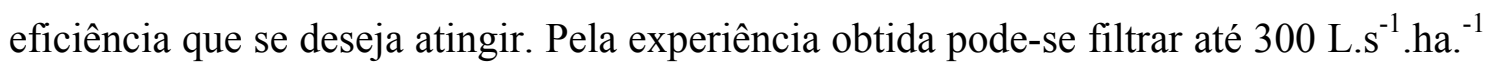
(SALATI, 1998).

A função depuradora dos solos filtrantes ocorre através de sua ação como filtro mecânico, filtro físico-químico e filtro biológico (MANFRINATO, 1989): 
a) filtragem mecânica - depende da estrutura granulométrica do solo e da sua composição;

b) filtragem físico-química - retenção de cátions e ânions, que está intimamente relacionada à capacidade de troca catiônica do solo;

c) filtragem biológica - exercida através dos seguintes mecanismos:

- ação de microrganismos do solo que decompõem a matéria orgânica, ativam os processos biogeoquímicos e atuam sobre os demais organismos;

- ação de plantas que crescem e retiram nutrientes do solo ao mesmo tempo em que mantêm a sua permeabilidade através do sistema radicular (MANFRINATO, 1989).

Os sistemas de solos filtrantes funcionam, dependendo do efluente a ser tratado, com fluxo descendente (Fig. 4) ou ascendente (Fig. 5). Este último é normalmente utilizado no tratamento secundário e terciário de esgoto urbano. Ele apresenta como vantagem a diminuição dos custos com tratamento primário convencional, ao se associar esta tecnologia a fossas sépticas ou simplesmente caixas de decantação, e o não contato direto com o efluente a ser tratado, eliminando desta forma possíveis problemas de mau odor e proliferação de insetos (SALATI, 1998).

Geralmente são implantados no mínimo dois módulos de solos filtrantes para serem utilizados de forma alternada, proporcionando adequado tempo de retenção hidráulica e períodos de pousio entre os solos, e evitando assim sua colmatação (SALATI, 2000).

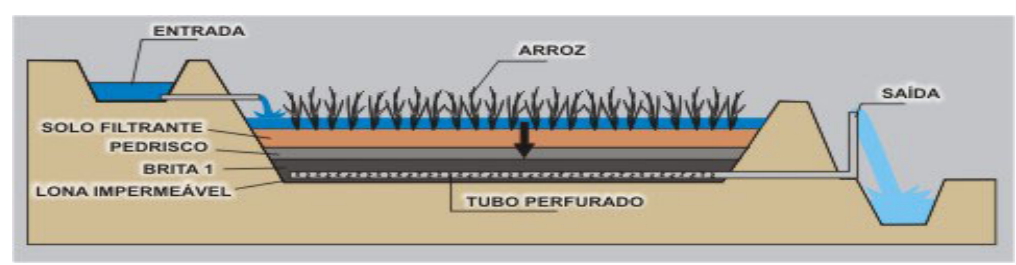

Figura 4: Desenho esquemático da estrutura de um solo filtrante com fluxo descendente. Fonte: SALATI, 2000.

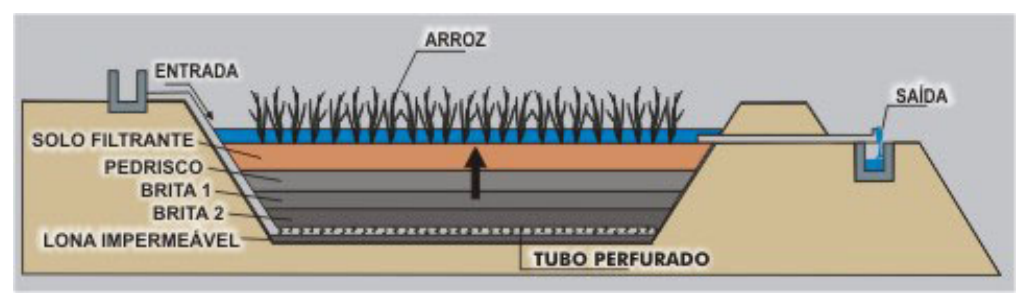

Figura 5: Desenho esquemático da estrutura de um solo filtrante com fluxo ascendente. Fonte: SALATI, 2000. 
São utilizados materiais impermeabilizantes no canal de macrófitas e nos módulos DHS para evitar a contaminação do solo e do lençol freático.

Segundo Cooper (1998), tem crescido o interesse em sistemas de fluxo subsuperficial devido a sua maior capacidade de transferência de oxigênio à medida que o efluente é drenado, favorecendo, desta forma, os processos de decomposição aeróbios e a nitrificação.

\subsubsection{Sistemas de Wetlands combinados}

Tendo em vista que cada técnica de área alagada construída possui maior eficiência para purificação de determinadas variáveis, alguns sistemas de purificação hídrica têm sido projetados utilizando uma combinação de técnicas (BRIX, 1993; SALATI, 2000; KOLTEC, 2004.). Esta combinação pode incluir unidades com diferentes tipos de macrófitas, substratos e sentidos de fluxo (BRIX, 1993).

A utilização de um determinado tipo de wetland ou de uma combinação depende do nível de tratamento a ser atingido, da qualidade dos recursos hídricos, da área disponível, do interesse da utilização da biomassa produzida e até mesmo do interesse paisagístico (KOLTEC, 2004).

No Brasil, vários projetos foram desenvolvidos pelo Instituto de Ecologia Aplicada, atual Instituto Terramax, utilizando uma combinação de sistemas de alagados construídos para purificação de diferentes tipos de efluentes (IEA, 1997).

\subsubsection{Processos de Remoção de Poluentes}

Os alagados construídos podem efetivamente remover ou converter grandes quantidades de poluentes de fontes pontuais (efluentes domésticos e industriais, e percolados de aterro sanitário) e difusas (escoamento urbano, agrícola e de minas) dentre eles, a matéria orgânica, os sólidos suspensos, o nitrogênio, o fósforo, os traços de metais e os patógenos (HAMMER \& BASTIAN, 1989; BRIX, 1993).

A filtração natural, a sedimentação e outros processos ajudam a "limpar a água" desses poluentes. Alguns são físicos e outros são quimicamente imobilizados e permanecem no sistema a menos que perturbados. Reações químicas e decomposição biológica quebram componentes complexos em substâncias simples. Através da absorção e assimilação, as plantas podem remover nutrientes para produção de biomassa adicional (HAMMER \& BASTIAN, 1989). 
O tratamento de águas poluídas em áreas alagadas, segundo Figueiroa (1996) é dependente da própria coluna d’água, do substrato, da vegetação (macrófitas), da população de microrganismos associada a estes elementos e dos animais vertebrados e invertebrados.

Segundo Salati (2000), a hidrologia do sistema tem um papel fundamental no estabelecimento da estrutura das comunidades (diversidade e arranjo dos organismos aquáticos) e nas funções ecológicas (ciclagem de nutrientes e produtividade primária).

A coluna d’água transporta substâncias e gases para a população de microrganismos, fornece meio ambiente e condições para os processos bioquímicos, além de transportar os produtos finais do metabolismo (HAMMER, 1993).

Os substratos variáveis de solo, areia e cascalho fornecem um meio suporte para as plantas; áreas superficiais consideravelmente reativas para cátions, ânions e outros complexos de componentes; e superfície de fixação para a população microbiana (HAMMER, 1993).

As plantas aquáticas são muito importantes para a melhoria da qualidade das águas, uma vez que funcionam como filtros, retendo partículas à medida que a água passa pelas mesmas, e fornecem quantidades substanciais de área de contato para a adesão de microrganismos (BRIX, 1993; HAMMER, 1993). Através dos mecanismos de absorção e assimilação, elas também são capazes de remover uma grande quantidade de nutrientes das águas poluídas, muitos dos quais ficam presos no sistema pelos sucessivos ciclos de crescimento, morte e decomposição (HAMMER \& BASTIAN, 1989, WATSON et al, 1989).

Além disso, as macrófitas (Fig.6) têm a habilidade de transportar gases atmosféricos, incluindo o oxigênio, para suprir a demanda respiratória dos tecidos das raízes, bem como oxigenar a rizosfera (HAMMER \& BASTIAN, 1989).

Essa transferência de oxigênio permite que algumas oxidações químicas ocorram nesta região, no entanto o mais importante é o fato da rizosfera fornecer condições para que uma grande população de bactérias se estabeleça e possa fazer modificações desejáveis de nutrientes, íons metálicos e outros componentes (BRIX, 1993). A justaposição de regiões aeróbicas rodeadas por anaeróbicas é crucial para os processos de nitrificação e desnitrificação, e de outras transformações de poluentes (BRIX, 1994; HAMMER \& BASTIAN, 1989). 


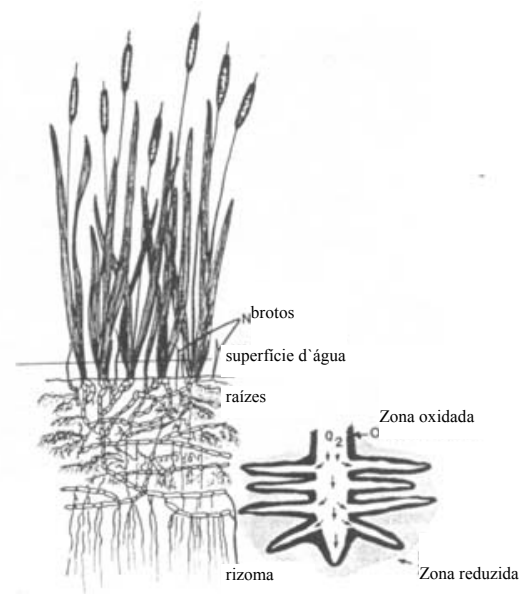

Figura 6: Plantas de áreas alagadas com habilidade de transportar oxigênio para o crescimento das raízes em substratos anaeróbios. Fonte: HAMMER \& BASTIAN, 1989 (modificado).

No entanto, para sustentar a alta produtividade e retirar do sistema os nutrientes incorporados, é necessário também que haja o manejo adequado das plantas, com colheitas periódicas da biomassa (OLIVEIRA, et al. 1998).

As bactérias, os fungos, as algas e os protozoários podem obter nutrientes ou energia para completarem seus ciclos de vida a partir de substâncias contaminantes. Muitos grupos de zooplâncton são predadores e agem sobre os organismos patogênicos. O filme biológico formado na rizosfera e nas raízes das macrófitas é composto por colônias de bactérias, protozoários e micrometazoários que degradam a matéria orgânica e tornam os nutrientes disponíveis.

Os microrganismos ocorrem naturalmente na maioria das águas com nutrientes e fontes de energia (HAMMER, 1993; HAMMER \& BASTIAN, 1989; MARQUES, 1999). No entanto, existem temperaturas máximas e mínimas que determinam os processos químicos, as atividades bioquímicas e as taxas de crescimento microbiano. Cada espécie é caracterizada por uma faixa de temperatura ótima de crescimento. A eficácia das áreas alagadas na purificação da água é dependente do desenvolvimento e manutenção de um meio ambiente ótimo para estas populações pertencentes ao ecossistema (HAMMER, 1993).

Animais vertebrados e invertebrados adquirem nutrientes e energia quando se alimentam da microbiota e das macrófitas, reciclando e, em alguns casos, transportando substâncias para o lado de fora de uma área alagada. Esses componentes têm papel limitado nas transformações dos poluentes, mas podem servir como indicadores da 
saúde e do bem-estar de um alagado, podendo sinalizar quanto a um mau funcionamento no mesmo (HAMMER, 1993).

Um resumo dos mecanismos básicos de remoção de poluentes pode ser visualizado na tabela 2 .

Tabela 2: Mecanismos de remoção de poluentes em alagados construídos.

\begin{tabular}{|c|c|}
\hline $\begin{array}{l}\text { CONSTITUINTES DAS } \\
\text { ÁGUAS RESIDUÁRIAS }\end{array}$ & MECANISMOS DE REMOÇÃO \\
\hline Sólidos Totais & $\begin{array}{l}\text { - Sedimentação/Filtração } \\
\text { - Decomposição } \\
\text { - Precipitação e co-precipitação } \\
\text { - Oxidação pelos microrganismos } \\
\text { - Assimilação pelas plantas }\end{array}$ \\
\hline $\mathrm{DBO}$ e $\mathrm{DQO}$ & $\begin{array}{l}\text { - Degradação microbiana (aeróbia e anaeróbia) } \\
\text { - Sedimentação (acumulação de matéria orgânica } \\
\text { na superfície do sedimento) } \\
\text { - Filtração }\end{array}$ \\
\hline Fósforo & $\begin{array}{l}\text { - Reações de adsorção aos sítios das plantas e } \\
\text { microbiota } \\
\text { - Precipitação com Al, Fe, Ca e argilo minerais do } \\
\text { solo } \\
\text { - Formação de complexos com a matéria orgânica } \\
\text { - Assimilação pelas plantas aquáticas e microbiota }\end{array}$ \\
\hline Nitrogênio & $\begin{array}{l}\text { - Amonificação seguida pela Nitrificação } \\
\text { e Desnitrificação } \\
\text { - Assimilação pelas plantas aquáticas } \\
\text { - Volatilização da amônia }\end{array}$ \\
\hline Sulfato & $\begin{array}{l}\text { - Adsorção (troca catiônica) } \\
\text { - Respiração do sulfato } \\
\text { - Precipitação de sulfetos metálicos }\end{array}$ \\
\hline Metais & $\begin{array}{l}\text { - Sedimentação/Filtração } \\
\text { - Reações de adsorção } \\
\text { - Precipitação com material orgânico e acúmulo no }\end{array}$ \\
\hline Metais & $\begin{array}{l}\text { - Precipitação na forma de hidróxidos e sulfetos } \\
\text { - Assimilação pelas plantas aquáticas } \\
\text { - Transformações microbianas (oxidação) }\end{array}$ \\
\hline Fenol & $\begin{array}{l}\text { - Adsorção a matéria orgânica e partículas do solo } \\
\text { - Degradação microbiana }\end{array}$ \\
\hline Patógenos & $\begin{array}{l}\text { - Sedimentação/Filtração } \\
\text { - Radiação ultravioleta } \\
\text { - Oxidação } \\
\text { - Adsorção a matéria orgânica } \\
\text { - Predação e ataque por vírus } \\
\text { - Morte natural } \\
\text { - Exposição a biocidas excretados por macrófitas }\end{array}$ \\
\hline
\end{tabular}




\subsubsection{DBO e DQO}

A demanda bioquímica de oxigênio retrata a quantidade de oxigênio requerida para estabilizar, através de processos bioquímicos, a matéria orgânica carbonácea (VON SPERLING, 1996). Já a demanda química de oxigênio relata a quantidade de oxidante químico necessária para oxidar compostos orgânicos presentes no efluente (KADLEC et al., 2000).

Os resultados de DQO são, portanto, mais elevados do que os obtidos para $\mathrm{DBO}_{5}$, uma vez que o oxidante químico reage com um amplo grupo de compostos (KADLEC \& KNIGHT, 1996).

Os componentes orgânicos são rapidamente removidos no sistema por sedimentação e filtração. Eles são também degradados aeróbia e anaerobiamente pelas bactérias fixadas nas plantas e presentes na superfície do sedimento (BRIX, 1993). O oxigênio requerido para a degradação aeróbia é fornecido pelas raízes das macrófitas (rizosfera), pela interface ar/água ou pela fotossíntese das algas.

A assimilação da matéria orgânica pelas plantas é desprezível quando comparada com a degradação biológica (WATSON et al., 1989). Estes microrganismos necessitam de uma fonte de energia de carbono para se reproduzirem e manterem suas funções. Como conseqüência a demanda bioquímica é consumida assim que a água passa pelos sistemas de alagados (KADLEC, 1994).

Segundo Kadlec e colaboradores (2000), uma concentração insuficiente de oxigênio dissolvido na água pode diminuir a oxidação biológica e prejudicar a remoção da variável no sistema.

Altas eficiências de remoção são alcançadas em alagados que recebem efluentes com grandes cargas orgânicas enquanto que as menores geralmente ocorrem em sistemas de fluxo superficial que recebem efluentes previamente tratados (WATSON et al., 1989).

\subsubsection{Fósforo}

O fósforo é um constituinte fundamental para os processos do metabolismo dos seres vivos (ATP e fosfolipídeos), mas como constituinte das águas residuárias tem sido apontado como o principal responsável pela eutrofização. 
Nos ambientes aquáticos, o fósforo pode apresentar-se das seguintes formas: ortofosfato $\left(\mathrm{PO}_{4}{ }^{3-}, \mathrm{HPO}_{4}{ }^{2-}, \mathrm{H}_{2} \mathrm{PO}_{4}^{-}, \mathrm{H}_{3} \mathrm{PO}_{4}\right)$, polifosfatos, fósforo orgânico (ESTEVES, 1988).

A remoção de fósforo em áreas alagadas construídas ocorre como conseqüência da adsorção nos sítios das plantas e substrato, formação de complexos com a matéria orgânica, reações de precipitação com alumínio $(\mathrm{Al})$, ferro $(\mathrm{Fe})$, cálcio $(\mathrm{Ca})$ e minerais do sedimento, e absorção pelas macrófitas e fitoplâncton (ESTEVES, 1988; KADLEC et al., 2000; WATSON et al., 1989).

As reações de adsorção e precipitação são os principais mecanismos de remoção quando a água residuária tem oportunidade de entrar em contato com uma parte significativa de solo ou sedimento (REED, CRITES \& MIDDLEBROOKS, 1995).

A ação dos íons de ferro sobre a dinâmica do fosfato depende do seu estado de oxidação, que por sua vez depende da concentração de oxigênio dissolvido e do pH do meio. Em ambientes onde predominam condições de oxidação e $\mathrm{pH}$ próximo do neutro, grande parte dos íons de ferro encontra-se na forma oxidada $\left(\mathrm{Fe}^{3+}\right)$ e desta forma, a grande maioria apresenta-se precipitada ou complexada na forma de hidróxido de ferro hidratado. O hidróxido de ferro hidratado pode adsorver espécies fosfatadas e outros metais em sua superfície (ESTEVES, 1988).

A precipitação pode ocorrer também através das argilas. Entre os componentes principais do solo estão os minerais secundários, e dentre eles, as argilas, que apresentam grande capacidade de adsorção de fosfato, principalmente aqueles que têm na sua constituição ferro e alumínio (hematita e gipsita). A adsorção de fosfato às argilas pode compreender dois processos: a ligação química da carga negativa do fosfato com a positiva das bordas das argilas e a substituição dos silicatos de argila por fosfato (ESTEVES, 1988).

Em solos ácidos, o fósforo é fixado como fosfato férrico ou de alumínio. Já em locais de $\mathrm{pH}$ elevado, o cálcio e o magnésio podem ter um papel mais importante na precipitação do fosfato do que os demais íons (ESTEVES,1988; REDDY \& D'ANGELO, 1994).

Se o solo tornar-se anaeróbio como resultado de inundação, o $\mathrm{Fe}^{3+}$ será reduzido a $\mathrm{Fe}^{2+}$ que conduzirá a uma adsorção menos forte e liberação de fosfato para a coluna d’água (FAULKNER \& RICHARDSON, 1989). 
Em condições redutoras (meio anaeróbio) o enxofre apresenta-se normalmente sob a forma de $\mathrm{H}_{2} \mathrm{~S}$, e nestas condições, o sulfeto normalmente combina-se com o ferro liberando o fósforo (REDDY \& D`ANGELO, 1994).

Em alagados de fluxo superficial, a adsorção ao solo fornece uma remoção inicial do fósforo, mas esse armazenamento parcialmente reversível pode se tornar saturado. Para algumas condições antecedentes, pode acontecer até uma liberação inicial da variável (KADLEC, et al., 2000) e essa difusão do solo para a água depende do gradiente de concentração (DUNNE et. al, 2005; REDDY \& D'ANGELO, 1994). Segundo estes autores, a sustentabilidade da remoção envolve a formação de um novo sedimento e, desta forma, criação de novos sítios ativos de adsorção.

A remoção do fósforo também pode ocorrer através da absorção e assimilação pelas macrófitas e microbiota, no entanto, esta capacidade de assimilação é reduzida com o aumento da concentração de fosfato nos tecidos (ELIAS, 2003).

A vegetação funciona como um armazenamento temporário de nutrientes e durante a estação de crescimento, particularmente, grandes quantidades de nutrientes são absorvidas pelo sistema radicular. Se a vegetação não é colhida, a maioria destes nutrientes acaba voltando ao sistema quando as plantas entram em decomposição. Só uma pequena parte dos nutrientes absorvidos permanece na vegetação armazenados em longo prazo como parte das fibras do colmo ou material de rizoma (WATSON et al., 1989; KADLEC et al., 2000).

No entanto, para alguns sistemas é desejável que as plantas entrem em decomposição e desta forma, haja a deposição de uma nova camada de sedimento (novos sítios ativos de adsorção), como já citado anteriormente (KADLEC et al., 2000).

Segundo Sculthorpe ${ }^{7}$ (1967) citado por ELIAS (2003), as macrófitas aquáticas apresentam ritmos diários de excreção de fosfato. Deste modo, uma parte do fosfato assimilado é devolvida ao meio através de exsudados excretados ativamente.

\subsubsection{Nitrogênio}

O nitrogênio é um dos elementos mais importantes no metabolismo de ecossistemas aquáticos, no entanto, deve estar presente em baixas concentrações na

${ }^{7}$ SCULTHORPE, C.D. (1967). The biology of aquatic vascular plants. Edward Arnold Ltd., London, p. 157-164. 
água potável para proteção da saúde infantil e deve ser limitado nas águas superficiais para proteger a vida dos peixes e evitar a eutrofização (ESTEVES, 1988; VALENTIM, 2003).

Nos ambientes aquáticos, o nitrogênio pode ser encontrado sob várias formas: nitrato $\left(\mathrm{NO}_{3}{ }^{-}\right)$, nitrito $\left(\mathrm{NO}_{2}^{-}\right)$, amônia $\left(\mathrm{NH}_{3}\right)$ ou íon amônio $\left(\mathrm{NH}_{4}{ }^{+}\right)$, óxido nitroso $\left(\mathrm{N}_{2} \mathrm{O}\right)$, nitrogênio molecular $\left(\mathrm{N}_{2}\right)$, nitrogênio orgânico dissolvido (aminoácidos, purinas) e em suspensão - matéria protéica (ESTEVES, 1988). Segundo Pádua (2004), o nitrogênio orgânico pode ser também chamado de nitrogênio albuminóide, e é resultante de excretas, urina, fezes ou da morte dos seres vivos, estando na forma de proteínas, aminoácidos e uréia (VON SPERLING, 1996).

Os principais mecanismos de remoção de nitrogênio em áreas alagadas construídas são os processos seqüenciais de amonificação, nitrificação e desnitrificação (KADLEC et al., 2000).

A amonificação é a formação de amônia durante o processo de decomposição da matéria orgânica particulada e dissolvida. A amônia é resultante da decomposição tanto aeróbia quanto anaeróbia da parte nitrogenada da matéria orgânica por organismos heterotróficos. O sedimento é o principal sítio de realização deste processo (ESTEVES, 1988).

A amônia pode estar presente no sistema em duas formas: amônia molecular $\left(\mathrm{NH}_{3}\right.$ que é tóxica para os peixes) ou íons amônio $\left(\mathrm{NH}_{4}{ }^{+}\right)$, sendo o equilíbrio entre as duas formas na água dependente do $\mathrm{pH}$ e a da temperatura.

Em relação ao pH tem-se:

$$
\begin{array}{ll}
\mathrm{pH}<8 & \text { praticamente toda amônia na forma de } \mathrm{NH}_{4}^{+} \\
\mathrm{pH}=9,5 & \text { aproximadamente } 50 \% \mathrm{NH}_{3} \text { e } 50 \% \mathrm{NH}_{4}^{+} \\
\mathrm{pH}>11 & \text { praticamente toda a amônia na forma de } \mathrm{NH}_{3}
\end{array}
$$

$\mathrm{O}$ pH ótimo para o processo de amonificação varia de 6.5 a 8.5 . A $25^{\circ} \mathrm{C}$ e $\mathrm{pH}$ igual a sete, a porcentagem de amônia não ionizada é de aproximadamente $0,6 \%$ (USEPA $^{8}, 1999$ apud VALENTIM, 2003).

A oxidação da amônia a nitrato através de bactérias nitrificantes em condições aeróbias é denominada nitrificação. A temperatura ótima para a ocorrência da

8 USEPA (1999). Constructed wetlands treatment of municipal wastewaters EPA/625/r-99/010, September /1999, Cincinnati, Ohio. 152p. 
nitrificação é de 20 a $25^{\circ} \mathrm{C}$ (KADLEC et al., 2000). Vymazal ${ }^{9}$ (1995) citado por esses autores disse que a nitrificação é influenciada pela temperatura, $\mathrm{pH}$, alcalinidade, fonte de carbono, população microbiana, concentração de oxigênio dissolvido e amônia. A alcalinidade é consumida e íons hidrogênio são liberados durante o processo de nitrificação. Portanto, altas taxas de nitrificação reduzem os valores de alcalinidade e do pH da água (ESTEVES, 1988).

Segundo Cooper ${ }^{10}$ et al. (1996) citado por Kadlec e colaboradores (2000), as bactérias nitrificantes são organismos sensíveis e extremamente susceptíveis a uma vasta gama de inibidores, inclusive a altas concentrações de nitrogênio amoniacal. Como os processos anaeróbios dominam nos alagados construídos, a nitrificação somente irá ocorrer através da utilização do oxigênio liberado pelas raízes (rizosfera) ou se forem introduzidas zonas abertas para que haja transferência do oxigênio atmosférico para a água através da interface ar/água. O acúmulo de amônia pode ser observado em sistemas anaeróbios devido ao declínio das taxas de nitrificação.

A desnitrificação é um processo de decomposição anaeróbia onde a matéria orgânica é quebrada através de bactérias heterotróficas, que utilizam o nitrato como aceptor de elétrons no lugar do oxigênio. Este processo acontece em duas etapas (ESTEVES, 1988):

a) o nitrato é reduzido a óxido nitroso $\left(\mathrm{N}_{2} \mathrm{O}\right)$;

b) o óxido nitroso é reduzido subseqüentemente a nitrogênio gasoso $\left(\mathrm{N}_{2}\right)$.

Os produtos finais das duas etapas são gases emitidos na atmosfera. $\mathrm{O}$ baixo $\mathrm{pH}$ é inibidor da segunda etapa de desnitrificação, de forma que todo o nitrogênio é liberado na forma de óxido nitroso.

A quantidade de $\mathrm{N}_{2}$ e $\mathrm{N}_{2} \mathrm{O}$ produzida é afetada pela quantidade de oxigênio dissolvido, pela temperatura e pela razão nitrato/amônio. $\mathrm{O}$ pH ótimo varia entre 7 e 8 , no entanto a alcalinidade produzida na desnitrificação pode resultar em um aumento do pH (VYMAZAL ${ }^{11}, 1995$ citado por KADLEC et al., 2000).

\footnotetext{
${ }^{9}$ VYMAZAL, J. (1995). Algae and element cycling in wetlands. Boca Raton: Lewis Publisher.

${ }^{10}$ COOPER et al. (1996). Reed beds and constructed wetlands for wastewater treatment. Medmenham, Marlow: Wrc Publication.

${ }^{11}$ VYMAZAL, J. (1995). Algae and element cycling in wetlands. Boca Raton: Lewis Publisher.
} 
A desnitrificação é o mecanismo mais efetivo de remoção do nitrogênio pelas várzeas naturais e construídas e as temperaturas ótimas estão entre 25 e $65^{\circ} \mathrm{C}$ (KADLEC et al., 2000). O principal local de ocorrência da desnitrificação é o sedimento, pois além das baixas condições de oxigenação, há disponibilidade de grande quantidade de substrato orgânico necessário para decomposição anaeróbia (ESTEVES, 1988).

Segundo Kadlec (1994), a nitrificação é um processo variável no sistema, uma vez que necessita da presença de oxigênio, que às vezes encontra-se com valores muito baixos. Em contraste, a remoção de nitrato parece ser efetiva na maioria dos casos, presumidamente devido a desnitrificação (na presença de substrato orgânico); conseqüentemente o nitrato é raramente encontrado em altas concentrações nos efluentes de descarga dos alagados construídos.

O nitrogênio pode ser também assimilado pela planta (amônia e nitrato), incorporado à biomassa e liberado de volta como nitrogênio orgânico após a decomposição.

O potencial de assimilação de nutrientes pela planta é limitado a sua taxa de crescimento e a concentração de nutrientes no tecido da planta. No entanto, segundo Brix (1994), é importante notar que a quantidade de nutriente, removida pelas macrófitas no tratamento secundário, é geralmente insignificante em comparação a concentração da água residuária (BRIX, 1994). Se a wetland não é manejada (colheita), a grande maioria dos nutrientes que foram incorporados ao tecido das plantas retorna a água após o processo de decomposição.

Outro mecanismo de remoção inclui a volatilização e a adsorção da amônia nos sítios ativos da matriz do solo, entretanto, esses mecanismos são menos importantes do que a nitrificação-desnitrificação (KADLEC et al., 2000). A volatilização ocorre com intensidade em condições de altos valores de $\mathrm{pH}$ e de temperatura (KADLEC \& KNIGHT, 1996).

Reddy e D`Angelo (1994) relataram que a eficiência de remoção de um sistema pode ser reduzida em sistemas que recebem efluentes com baixa concentração de nitrogênio. Nesta situação, a produção interna e a liberação de nitrogênio são maiores do que a assimilação, resultando em taxas negativas de remoção.

O potencial de remoção de nitrogênio pode levar alguns anos para se desenvolver nos sistemas de alagados, uma vez que requer pelo menos de duas a três estações de crescimento das plantas, desenvolvimento dos sistemas de raízes e matérias 
bentônicas, além da deposição de uma nova camada de solo para alcançar o equilíbrio (REED, CRITES \& MIDDLEBROOKS, 1995).

A eficiência de remoção de nitrogênio pode ser reduzida também em função do surgimento de condições limitantes como: baixo tempo de retenção hidráulica, baixas temperaturas, condições de pH muita ácidas ou básicas (inibição do processo de nitrificação e desnitrificação), concentração de oxigênio e alcalinidade insuficientes para o processo de nitrificação e fonte de carbono insuficiente para suportar o processo de nitrificação e desnitrificação (ELIAS, 2003; ESTEVES, 1988; KADLEC et al., 2000; WATSON et al., 1989).

\subsubsection{Sulfato}

O íon sulfato pode ser removido no sistema por processos químicos e biológicos. O processo químico envolve a adsorção do íon sulfato (troca catiônica) nas partículas do solo assim como citado para o fosfato. No entanto, o sulfato adsorvido no solo pode ser deslocado pelo fosfato nos sítios de troca (FAULKNER \& RICHARDSON, 1989).

A remoção do sulfato por processo biológico ocorre em ambientes aquáticos sob condições anaeróbias através de bactérias heterotróficas denominadas dessulfurantes (ESTEVES, 1988; FAULKNER \& RICHARDSON, 1989). O sulfato é utilizado como aceptor final de elétrons (respiração do sulfato) e como resultado, tem-se a produção de $\mathrm{H}_{2} \mathrm{~S}$ e alcalinidade (HEDIN, HAMMACK \& HYAMAN, 1989). O gás sulfídrico formado é liberado para a atmosfera ou se dissolve na água. No segundo caso, ele se ioniza e gera íons sulfeto, que reagem com uma série de íons metálicos precipitando-os (FAULKNER \& RICHARDSON, 1989).

A redução do sulfato em alagados construídos para tratar efluentes ácidos de mineradoras é bastante desejável, uma vez que o $\mathrm{H}_{2} \mathrm{~S}$ formado ioniza e reage com os metais dissolvidos precipitando-os e a alcalinidade produzida é responsável pela neutralização da acidez (HEDIN, HAMMACK \& HYAMAN, 1989).

\subsubsection{Metais}

Os processos de remoção incluem: sedimentação, filtração, adsorção, formação de complexos, precipitação, assimilação pelas plantas e reações bacterianas principalmente de oxidação (FAULKNER \& RICHARDOSN, 1989; KADLEC et al., 2000; REED, CRITES \& MIDDLEBROOKS, 1995; WATSON et al., 1989). 
Traços de metais têm uma grande afinidade por adsorção e formação de complexos com materiais orgânicos e vão sendo acumulados no sedimento dos alagados (WATSON, 1989). Como os sedimentos orgânicos e inorgânicos estão continuamente aumentando nos alagados (em baixa taxa), a disponibilidade de novos sítios de adsorção é também aumentada (REED, CRITES \& MIDDLEBROOKS, 1995).

A presença de bactérias metal-oxidantes nas zonas aeróbias e das bactérias redutoras de sulfato em zonas anaeróbias, causam a precipitação dos óxidos e sulfatos de metal, respectivamente (KADLEC et al., 2000).

A redução do sulfato consome íons sulfato e produz alcalinidade e ácido sulfídrico, como já citado anteriormente. Este ácido dissolvido ioniza e gera íons sulfeto, que reagem com uma grande quantidade de íons de metais produzindo precipitados de sulfeto (ESTEVES; 1988; FAULKNER \& RICHARDSON, 1989; KADLEC et al., 2000).

A oxidação do ferro mediada pela bactéria Thiobacillus ferrooxidans (bactéria metal-oxidante), seguida pela subseqüente precipitação de hidróxido de ferro, é considerado o mais importante mecanismo de remoção do ferro. Estudos similares sugerem também oxidação para outros metais incluindo cobre, chumbo, manganês, níquel, prata e ouro e zinco. As plantas podem estimular o crescimento destas bactérias através da transferência de oxigênio para a rizosfera (KADLEC et al., 2000).

O hidróxido de ferro hidratado pode adsorver espécies fosfatadas e metálicas em sua superfície, precipitando-os, por exemplo, o metal manganês (coprecipitação)(FAULKNER \& RICHARDSON, 1989).

A vegetação pode atuar na remoção de metais pela assistência direta da filtração da matéria orgânica particulada. As espécies de macrófitas com grandes áreas de superfície também se têm mostrado eficientes em reter as partículas de hidróxido de metal que precipitam na solução (KADLEC et al., 2000).

A assimilação pela microbiota e das macrófitas podem ser também consideradas, uma vez que muitos metais são requeridos para o crescimento das mesmas (traços), como por exemplo: bário, boro, cromo, cobalto, cobre, enxofre, ferro, magnésio, manganês, níquel, selênio, e zinco. No entanto, estes mesmos também podem ser tóxicos em altas concentrações. Outros metais como: arsênio, cádmio, chumbo, mercúrio e prata não têm papel biológico conhecido e podem ser tóxicos até em baixas concentrações (ESTEVES, 1988; KADLEC et al., 2000; WATSON et al., 1989). 
Segundo Kadlec e colaboradores (2000), quando a planta entra em decomposição, o conteúdo de metal é liberado para a coluna d’água. A colheita das folhagens pode somente minimizar esse efeito, uma vez que apenas pequenas concentrações estão na parte aérea da planta (KADLEC et al., 2000). Por isso, em alguns casos, é preferível evitar a retirada das folhagens para que ocorra a formação de uma nova camada de matéria morta no sedimento (litter) e desta forma, fornecer novos sítios de adsorção para remoção do metal.

\subsubsection{Fenol}

Os compostos fenólicos são definidos como hidróxidos derivados do benzeno e seus condensados (VON SPERLING, 1996). À origem dos fenóis em uma água pode ser atribuída aos dejetos industriais, hidrólise e oxidação fotoquímica dos agrotóxicos organofosforados e degradação microbiana de herbicidas (LEITÃO et al., 2006).

O fenol pode ser removido do sistema através da adsorção as partículas de matéria orgânica ou através das partículas argilosas do solo e degradação microbiana por bactérias (Pseudomonas) e fungos (Trichosporon e Candida). Alguns compostos fenólicos são resistentes à degradação microbiológica e são transportados a longas distâncias pela água (LEITÃO et al., 2006).

\subsubsection{Sólidos Totais}

A eficiência de remoção dos sólidos totais nos alagados construídos está relacionada aos mecanismos responsáveis pela remoção dos sólidos em suspensão e dos sólidos dissolvidos.

Com relação aos sólidos suspensos, destacam-se os processos de sedimentação, de filtração pelas raízes das macrófitas e pelo substrato e de decomposição aeróbia e anaeróbia. Para os sólidos dissolvidos, a eficiência de remoção está relacionada aos processos de adsorção aos sítios das macrófitas e do solo, precipitação e co-precipitação com componentes insolúveis, oxidação pelos microrganismos e a assimilação pelas plantas e microbiota (KADLEC et al., 2000; WATSON, et al., 1989).

Um número de processos ocorrentes nas wetlands produz matéria particulada: a morte de invertebrados, os fragmentos de detritos de plantas e algas, e a formação de precipitados químicos. As bactérias e fungos podem colonizar esses materiais e adicionar a sua massa (KADLEC et al., 2000). 
Os sedimentos e microdetritos dos alagados são facilmente perturbados, e bioperturbações por peixes, mamíferos e pássaros podem ressuspender este material e levar a um aumento dos sólidos suspensos no efluente (KADLEC et al., 2000).

O processo físico de sedimentação e filtração dos sólidos suspensos também é responsável pela remoção de porções significativas de outros constituintes das águas residuárias como DBO, nutrientes e patógenos (FAULKNER\& RICHARDSON, 1989; WATSON et al., 1989; KADLEC et al., 2000).

\subsubsection{Patógenos}

Os patógenos são removidos nos alagados através de uma combinação de processos físicos, químicos e biológicos.

Como físicos, pode-se citar a sedimentação, radiação ultravioleta e a filtração mecânica pelas plantas (fluxo superficial) e pelo solo (subsuperficial).

A oxidação, a adsorção pela matéria orgânica e a exposição a biocidas excretados por algumas plantas são considerados os processos químicos; e a morte natural ou por antibióticos, predação e ataque por bacteriófagos e outros vírus, os processos biológicos (GERSBERG, GEARHEART \& IVES, 1989; HYDE \& ROSS ${ }^{12}$, 1984 apud WATSON et al., 1989; KADLEC et al., 2000).

\subsection{3. Áreas Alagadas Construídas no Brasil}

A utilização de alagados construídos na melhoria da qualidade das águas, apesar de bem difundida em todo mundo, pode ser ainda considerada uma tecnologia recente no Brasil (SALATI FILHO; SALATI, Eneida \& SALATI, Enéas, 1999).

Segundo Elias (2003), a utilização de alagados artificiais no país é escassa. Apenas alguns pesquisadores têm despendido tempo para aprender e aperfeiçoar aspectos destas técnicas e, desta forma, melhorar a eficiência dos sistemas utilizados para purificação de diversos tipos de efluentes (SALATI FILHO, SALATI, Eneida \& SALATI, Enéas, 1999).

O primeiro projeto de sistemas de wetlands artificiais realizado no Brasil foi feito por Salati e colaboradores em 1982 e baseou-se na construção de um lago artificial nas proximidades de um córrego poluído (Rio Piracicamirim) na ESALQ, em Piracicaba

\footnotetext{
12 HYDE, H.C; ROSS, R.S. (1984). Technology Assessment of Wetlands for Municipal Wastewater Treatment, U.S. EPA Municipal Environmental Research Laboratory, Cincinnati, OH
} 
(SALATI ${ }^{13}$, 1984 apud SALATI, 1998). Os primeiros experimentos obtiveram resultados satisfatórios e o trabalho tem continuado desde 1985 pelo Instituto de Ecologia Aplicada (SALATI, 1998) atual Instituto Terramax.

Outro trabalho foi realizado por Manfrinato (1989) em um estudo para purificação das águas do Rio Piracicaba (pré-tratamento). A autora estudou dois tipos de sistemas: um canal de plantas aquáticas flutuantes seguido por solos filtrantes, e uma seqüência de dois solos filtrantes. No primeiro processo foi alcançada a eficiência média de remoção de $70 \%$ para $\mathrm{DBO}, 99 \%$ para coliformes totais e fecais, $90 \%$ para cor e $95 \%$ para turbidez. No sistema de solos filtrantes em seqüência observou-se um desempenho de $86 \%$ de remoção para DBO, $99 \%$ para coliformes totais e fecais, $95 \%$ para cor e $96 \%$ para turbidez.

Segundo o Instituto de Ecologia Aplicada (1997), os projetos desenvolvidos no país podem ser divididos de acordo com o efluente a ser tratado, em quatro tipos de sistemas:

a) purificação de grandes volumes de água com a finalidade de recuperação dos recursos hídricos ou pré-tratamento para ETA;

b) tratamento de esgoto urbano;

c) tratamento de efluente industrial;

d) abastecimento de água industrial e urbana.

Nesses últimos anos, os órgãos responsáveis pelo tratamento de esgoto e de águas para abastecimento público têm se interessado por este tipo de tecnologia. Dentre eles, a Companhia de Saneamento Básico de São Paulo (SABESP) e a de Saneamento do Paraná (SANEPAR) contrataram o IEA para a elaboração e aplicação de um projeto para "restaurar" os recursos hídricos através de wetlands artificiais e/ou reabilitar os alagados naturais (SALATI FILHO; SALATI, Eneida \& SALATI, Enéas, 1999).

Dentre alguns trabalhos realizados e aplicados pelo IEA (1997) pode-se citar:

- $\quad$ Tratamento e pré-tratamento de água para abastecimento público

Como exemplo da utilização de alagados construídos para tratamento e prétratamento de água para abastecimento público pode-se citar: a SABESP (Carapicuíba e

\footnotetext{
${ }^{13}$ SALATI, E. (1984). Método fitopedológico de despoluição de águas. Fundação Salim Farah Maluf.
} 
Baixo Cotia), SANEPAR e a ETA de Analândia (SALATI FILHO; SALATI, Eneida \& SALATI, Enéas, 1999).

Uma estação experimental (canal de macrófitas flutuantes, emergentes e solos filtrantes) foi construída para avaliar a eficiência do sistema de alagados na melhoria da qualidade das águas do Rio Cotia (pré-tratamento). As águas deste rio são usadas para abastecimento público após o tratamento convencional, e segundo a resolução CONAMA 357/2005 (BRASIL, 2005), deve atingir os parâmetros estabelecidos para rios de classe 2. No entanto, na maior parte do ano, as suas características excedem os valores máximos permitidos para sua classe, chegando a classe 3. Após a passagem pelo sistema de alagados construídos, observou-se uma remoção superior a $85 \%$ para os nutrientes, e superior a 90\% para coliformes totais e fecais (SALATI et al., 1999).

Em Analândia (Fig.7), um sistema combinado de alagados construídos (um canal de plantas aquáticas flutuantes e dois solos filtrantes) é utilizado para tratamento de água para abastecimento público. Após a passagem pelo alagado, a água é clorada (método com hipoclorito), filtrada (filtro de areia) e distribuída para a população (ELIAS, 2003). Segundo este autor, os resultados obtidos para as diversas variáveis relativas à qualidade da água para consumo humano indicam que, em todos os períodos analisados durante um ano, a água tratada se enquadrou nos limites e padrões de qualidade estabelecidos pela Portaria MS No 1.469 do Ministério da Saúde modificada e transformada na atual Portaria MS N 518 (BRASIL, 2004).

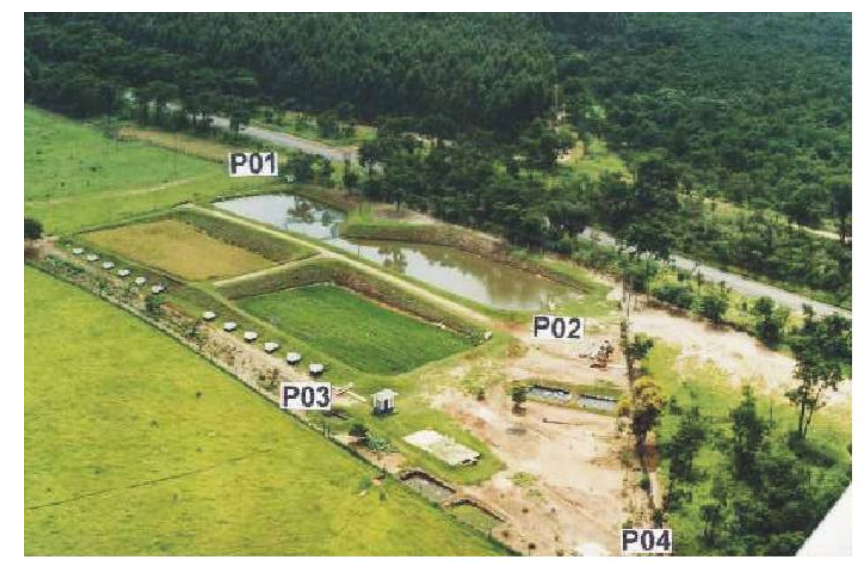

Figura 7: Tratamento de água para abastecimento público - ETA Analândia (SP) 6.480 hab.(15 L.S-1). P01: ponto na entrada do sistema (canal de MAF); P02: ponto de entrada do solo filtrante; P03: ponto na saída do solo; P04: ponto de coleta após a passagem pelo método de cloração e filtragem. Fonte: ELIAS, 2003. 
- Tratamento de esgoto

Como exemplo da utilização de alagados construídos para tratamento de esgoto pode-se citar: a ETE da Mineração Taboca (Vila de Pitinga-AM); ETE da Albrás Alumínio (Barcarena-PA); ETE do Emaús, (Ubatuba-SP) e a ETE do SEMAE Engenho Central I e II (Piracicaba-SP). As estações possuem um tratamento primário (decantação ou biodigestores) e um sistema de alagados com solos filtrantes e canais de plantas aquáticas (SALATI FILHO; SALATI, Eneida \& SALATI, Enéas, 1999).

A ETE da Comunidade de Emaús em Ubatuba utiliza fossa séptica para tratamento primário, sistemas combinados de alagados construídos para tratamento secundário (um módulos de solos filtrantes e dois canais de macrófitas flutuantes em seqüência) e uma composteira para tratamento do lodo e da biomassa produzida (SALATI FILHO; SALATI, Eneida \& SALATI, Enéas, 1999). Durante um estudo realizado por estes autores, sistema apresentou, em um estudo em 1999, uma eficiência de remoção superior 73\% da cor, $96 \%$ da DBO, $94 \%$ da DQO e 95\% da turbidez, promovendo um efluente dentro dos padrões exigidos para Classe 2 do CONAMA 357/2005 (BRASIL, 2005).

A ETE da Albrás Alumínio (Fig. 8) trata o efluente doméstico de 13.000 habitantes e é composta por um tanque de decantação, sistema de solos filtrantes e um canal de macrófitas aquáticas. No início de operação do sistema eficiências superiores a 95\% para $\mathrm{DBO}_{5}$, DQO e coliformes totais e fecais foram alcançadas (SALATI FILHO; SALATI, Eneida \& SALATI, Enéas, 1999).

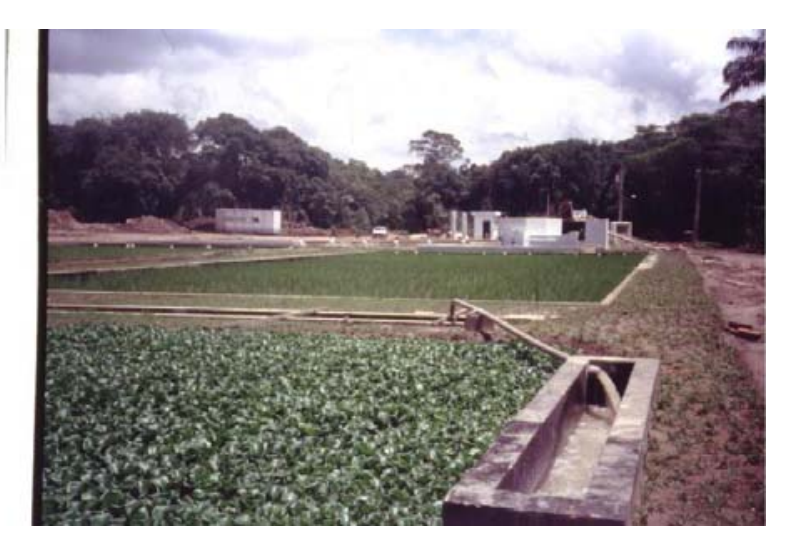

Figura 8: Tratamento de esgoto - ETE da Albrás Alumínio (PA). 13.000 hab $\left(67 \mathrm{~L} \cdot \mathrm{s}^{-1}\right)$. Fonte: SALATI, 2000. 
- Tratamento de efluentes industriais

Como exemplo de indústrias que utilizam o sistema de áreas alagadas para purificação de seu efluente pode-se citar: RIPASA S.A. - Celulose e Papel (Limeira/SP) e a Usina Costa Pinto S. A. (Piracicaba/SP) que possuem como tratamento primário tanque de estabilização e de fermentação, respectivamente. Após o tanque, o efluente passa por um sistema de solos filtrantes e canais de plantas aquáticas.

O primeiro grande projeto de alagados no Brasil, segundo Salati (1998), foi construído na Usina Costa Pinto (Fig.9) totalizando uma área de aproximadamente 1ha. O sistema é responsável por mais de $60 \%$ da remoção de DBO e DQO (SALATI FILHO; SALATI, Eneida \& SALATI, Enéas, 1999).

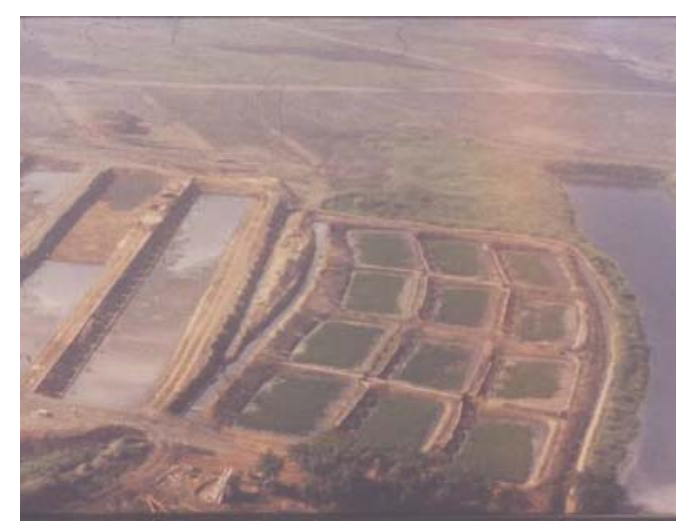

Figura 9: Tratamento de efluente industrial - Usina Costa Pinto (Piracicaba/SP) - 200L.s-1. Fonte: SALATI, 2000.

Outros projetos vêm sendo desenvolvidos por um grupo de pesquisadores da Universidade Federal e da Universidade Estadual do Rio de Janeiro, buscando o tratamento de líquidos percolados de aterro sanitário em áreas alagadas construídas. Campos e colaboradores (2002) desenvolveram um estudo utilizando o chorume proveniente do Aterro Sanitário de Piraí (RJ) e macrófitas emergentes.

Em Pernambuco, o grupo de estudos de resíduos sólidos (GRS) da UFPE, estudou o tratamento do chorume produzido no Aterro Sanitário de Muribeca (PE) através de um canal construído de plantas aquáticas emergentes (JUCÁ, 2003).

Borges e colaboradores (2003) da UNESP de Rio Claro fizeram um estudo para verificar a eficiência de leitos cultivados na remoção da DBO, DQO, dentre outros parâmetros, e de determinados microrganismos da água. A água a ser tratada foi retirada do Rio Corumbataí (Rio Claro/SP), naturalmente contaminada por resíduos industriais e 
esgoto doméstico, e propositadamente por microrganismos como: Saccharomyces cerevisiae, Bacillus subtilis, coliformes totais e Escherichia coli.

A conclusão obtida pelos pesquisadores foi que a aplicação destes sistemas mostrou-se eficiente na descontaminação dos efluentes utilizados, uma vez que os parâmetros analisados enquadraram-se nas exigências estabelecidas pela Resolução CONAMA 20/1986, que estava em vigor no período de estudo (BORGES et al., 2003), após o tratamento.

As pesquisas desenvolvidas pelo Instituto Nacional de Tecnologia (RJ) também podem ser citadas, dentre elas, o estudo sobre a destinação final das macrófitas das wetlands seja como fonte de proteína para alimentação animal (ROQUETE-PINTO \& LIMA, 1998), seja como fonte de energia - biogás (OLIVEIRA et al., 1998), e a remoção de metais pesados do sistema pelo aguapé (ROQUETE-PINTO, 1998).

Pesquisadores da UNICAMP utilizam alagados construídos de fluxo subsuperficial no pós-tratamento de efluentes oriundos de tanques sépticos. Nestes trabalhos, eles também avaliam o desempenho e o manejo das macrófitas utilizadas nos sistemas (VALENTIM, 1999, 2003).

Na Universidade de São Paulo podem ser encontrados estudos relacionados ao balanço de nutrientes e ciclos biogeoquímicos (NOGUEIRA, 2003), e à comunidade de rotíferos (PARESCHI, 2004) em uma área alagada construída em Piracicaba pertencente ao SEMAE (Serviço Municipal de Água e Esgoto) para tratamento de esgoto doméstico. Lautenschlager (2001) trabalhou com modelos matemáticos para simular a remoção de fósforo e nitrogênio total em alagados construídos. Beccato (2004) elaborou uma proposta de utilização de alagados artificiais para tratamento do esgoto da Comunidade do Marujá na Ilha do Cardoso.

Outros trabalhos com alagados construídos vêm sendo desenvolvidos, dentre os quais vale ressaltar os da Universidade Federal do Rio Grande do Sul (GIOVANINNI \& MARQUES 1998) e da Universidade Federal de Santa Catarina (PHILLIPHI \& COSTA 1998).

A utilização de áreas alagadas construídas para tratamento de efluentes apresenta além da alta eficiência de remoção de variáveis da qualidade da água, as seguintes vantagens (BRIX, 1993; KADLEC \& KNIGHT, 1996; SALATI, 2000):

- baixo custo de implantação e consumo de energia elétrica;

- simplicidade de instalação e operação; 
- capacidade de tratar diferentes níveis de poluição através de suas várias formas operacionais (espécies de plantas aquáticas, tipos de substratos, direcionamento de fluxo, dimensão e número de etapas depurativas);

- $\quad$ ausência de produção de lodo;

- geração de uma biomassa que pode ser utilizada na produção de ração animal, energia e biofertilizantes (reciclagem de nutrientes);

- fornecimento de benefícios indiretos como um espaço verde, habitat para animais selvagens e áreas de recreação e educação (HAMMER \& BASTIAN, 1989).

No entanto, segundo Brix (1993), tais sistemas apresentam como dificuldades a sua implantação: a necessidade de grandes áreas para construção, possível problema com pestes (mosquitos) e diminuição da eficiência do tratamento em baixas temperaturas.

Para o Brasil, estas desvantagens não justificam o baixo interesse por esse tipo de tratamento, uma vez que o país tem grandes áreas disponíveis, possui um clima Tropical e Subtropical que proporciona o crescimento da vegetação aquática durante todo o ano (ELIAS, 2003) e, de acordo com Salati (2000) os alagados construídos brasileiros não apresentam nenhum problema com relação aos mosquitos.

A tecnologia de utilização de plantas nos tratamentos de água para consumo humano, tratamento de esgoto e tratamentos de efluentes agrícolas e industriais, é muito importante, uma vez que conduz para um processo integrado auto-sustentável. No entanto, a planta depois de removida do sistema deve ser utilizada para algum fim, seja para a produção de energia, biofertilizantes ou ração animal (DEBUSK \& RYTHER ${ }^{14}$, 1987 conforme ELIAS, 2003).

${ }^{14}$ DEBUSK, T.A. RYTHER, J.M (1987). Biomass production on yields of aquatic plants. In: REEDY, K. R.; SMITH, W. H. (Ed.). Aquatic plants for waste treatment and resource recovery. Magnolia Orlando: Publishing, 


\section{MATERIAL E MÉTODOS}

\subsection{Local de Estudo}

O sistema de alagados construídos estudado situa-se nas dependências do Parque Ecológico do Tietê (PET) em São Paulo e foi criado em 1998 pela parceria entre a SABESP (Companhia de Saneamento Básico de São Paulo), DAEE (Departamento de Águas e Energia Elétrica), PET e demais voluntários (Fig. 10). A iniciativa teve como objetivo demonstrar, na prática, a capacidade dos ecossistemas de várzea em melhorar a qualidade das águas poluídas (FBDS, 2004).

A partir da implantação da estação de tratamento, foi proposta pela SABESP em conjunto com a FEHIDRO (Fundação Estadual de Recursos Hídricos) e o DAEE, a criação do Centro de Educação e Difusão de Tecnologias Ambientais (CEDTA). A criação deste centro foi executada pela Fundação Brasileira para o Desenvolvimento Sustentável (FBDS) com apoio do Instituto Terramax, SEREC e TAKAOKA (FBDS, 2004).

O CEDTA destina-se à Educação Ambiental, exposição e divulgação de tecnologias ambientais para os visitantes do parque e tem como principais atividades desenvolvidas: o tratamento de água com wetlands, geração de energias limpas (energia eólica e solar), biocompostagem, viveiros de mudas e minhocários.

Com relação aos alagados artificiais, devido a um longo período sem monitoramento da estação, foi proposta em 2003, uma restauração do sistema. O solo foi retirado e novamente preparado, assim como as macrófitas, que foram outra vez transplantadas e testadas quanto a sua adaptação.

A região do Parque Ecológico do Tietê pertence à bacia do Alto Tietê, que segundo Köppen está localizada no limite entre as zonas $\mathrm{Cfb}$ (sem estação seca, com verões tépidos) e a Cwb (inverno seco), com total mensal de chuva de 30 a $60 \mathrm{~mm}$ no mês mais seco. De acordo com Thornthwaite, ela encontra-se na faixa de transição entre Bbw (clima úmido mesotermal com inverno seco) e Bbr (clima úmido mesotermal sem época seca). 


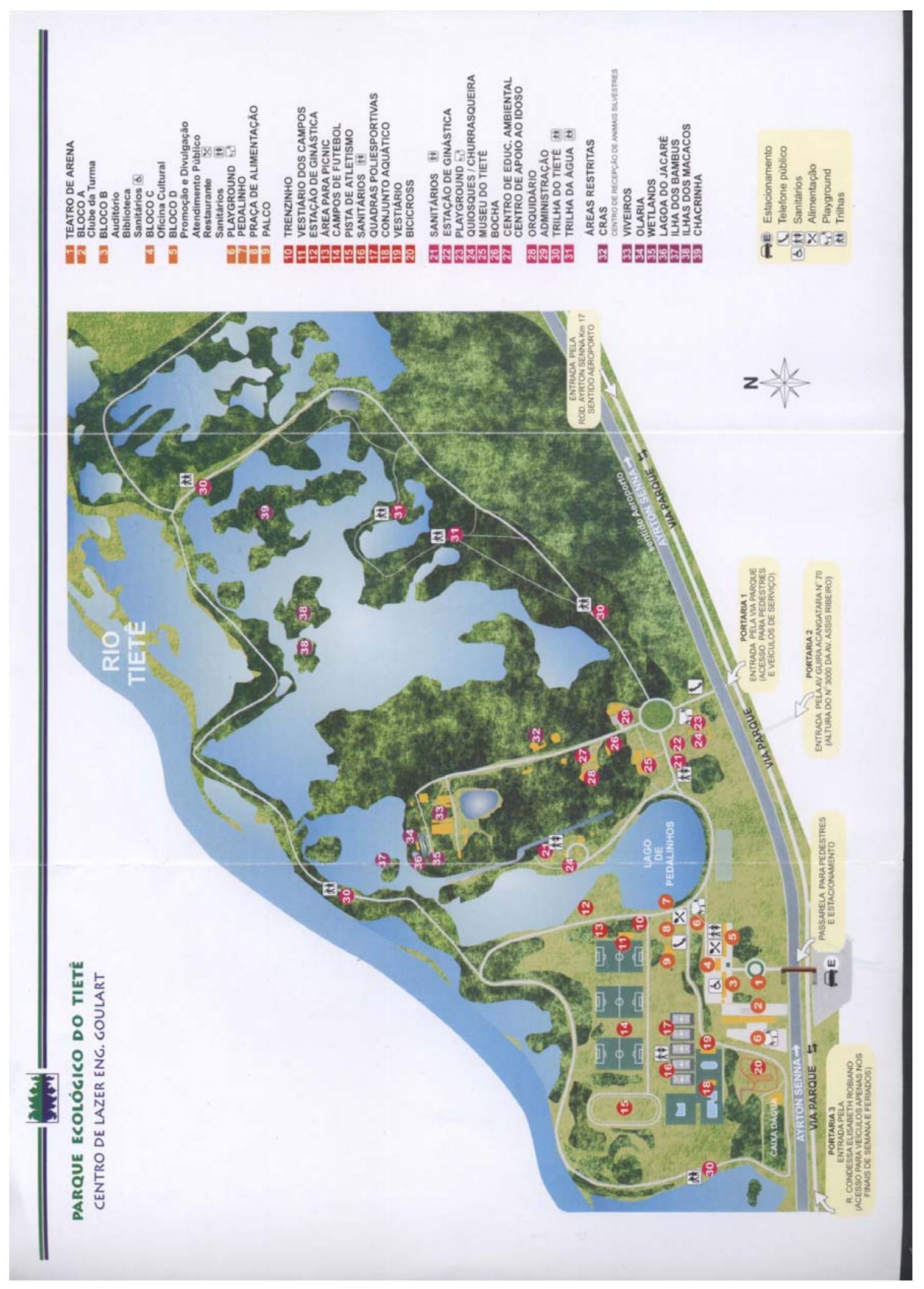

Figura 10: Folheto do Parque Ecológico do Tietê esquematizando a região do parque. O n 35 corresponde à localização da estação de alagados construídos. Fonte: Parque Ecológico do Tietê, 2006. 
A climatologia regional pode ser descrita por dados da Estação Metereológica do Departamento de Ciências Atmosféricas do Instituto Astronômico e Geofísico da Universidade de São Paulo (IAG-USP). A média histórica das chuvas na região mostra que os meses chuvosos (outubro a março) contribuem com $1022 \mathrm{~mm}$ de um total anual de $1372 \mathrm{~mm}$. Percentualmente, esse aporte de chuvas é responsável pelo suprimento de $75 \%$ do total anual. Os restantes $25 \%$, ou $350 \mathrm{~mm}$, ocorrem entre abril e setembro (IAGUSP).

\subsubsection{Descrição da estação de tratamento}

A estação de tratamento é composta por um canal de decantação e sistemas combinados de alagados construídos: um canal de macrófitas aquáticas flutuantes e emergentes, e células de solos filtrantes.

A água a ser tratada é bombeada de um lago adjacente ao Rio Tietê, dentro das dependências do PET, para a caixa de entrada da ETA. O fluxo da água de entrada é primeiramente conduzido para um canal de decantação, depois para um canal de plantas aquáticas e finalmente para os dois módulos de solos filtrantes. Após a passagem pelos canteiros, o fluxo total é conduzido para uma lagoa pertencente ao parque onde são criados jacarés.

A área total do sistema é de $1000 \mathrm{~m}^{2}$, sendo destinados $85 \mathrm{~m}^{2}$ para o canal de decantação, $530 \mathrm{~m}^{2}$ para o canal de macrófitas aquáticas flutuantes e emergentes, e $195 \mathrm{~m}^{2}$ para os solos filtrantes (Fig.12). Cerca $190 \mathrm{~m}^{2}$ foram reservados aos taludes e corredores entre os módulos de tratamento. O sistema foi projetado para trabalhar com uma vazão de $0,5 \mathrm{~L} \cdot \mathrm{s}^{-1}$.

\subsubsection{Canal de macrófitas aquáticas flutuantes e emergentes (MAFE):}

O canal MAFE de fluxo superficial horizontal (Fig. 11) ocupa cerca de $530 \mathrm{~m}^{2}$ de área superficial, com profundidade média de $0,72 \mathrm{~m}$, para a região com flutuantes e de $0,40 \mathrm{~m}$ para a de emergentes. Aproximadamente $89 \%$ do canal foram destinados para as plantas aquáticas (Fig.12) flutuantes (Eichhornia crassipes, Salvinia auriculata e Pistia stratiotes) enquanto que $11 \%$ para as macrófitas emergentes (Typha angustifolia). $\mathrm{O}$ volume estimado é de $400 \mathrm{~m}^{3}$ e o tempo de residência hidráulico teórico (TRH) é de aproximadamente 9 dias. 


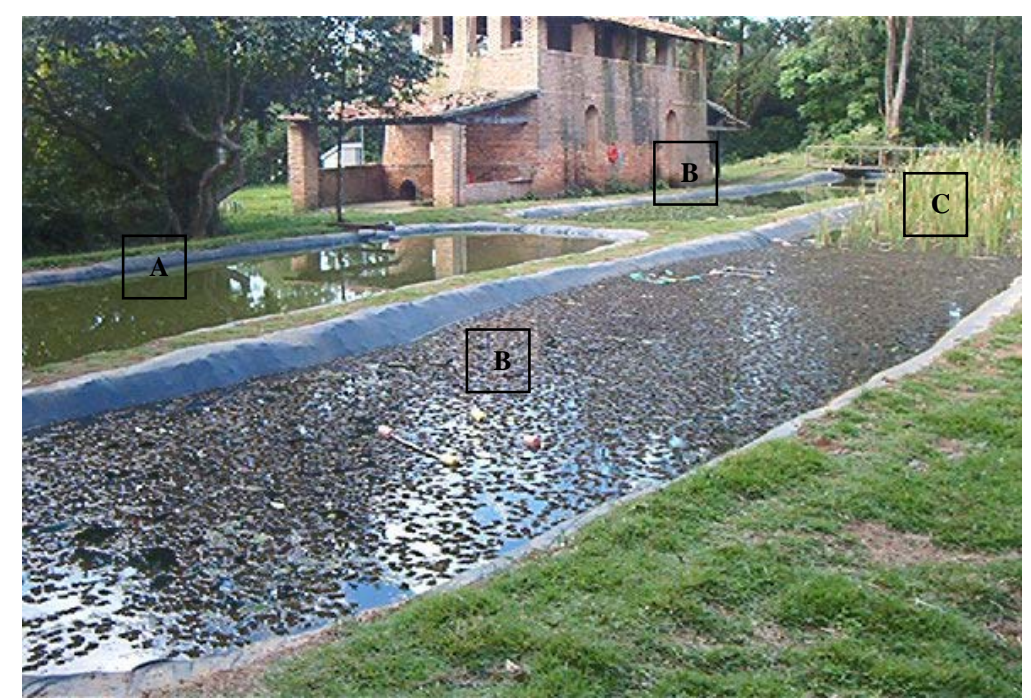

Figura 11: Canal de macrófitas aquáticas flutuantes e emergentes.

A. canal de decantação. B. macrófitas flutuantes. C. macrófitas emergentes. Fonte: FBDS, 2004

Durante o período de 30 de dezembro de 2003 a 27 de agosto de 2004, algumas plantas aquáticas foram testadas objetivando-se selecionar espécies ecologicamente adaptadas às características limnológicas do sistema e desta forma, aumentar a eficiência do tratamento evidenciado pela presença das macrófitas (FBDS, 2004).

- $\quad$ Plantas aquáticas flutuantes

No período de estudos foram transplantados inicialmente $560 \mathrm{~kg}$ de Eichhornia crassipes (aguapé), cerca $45 \mathrm{~m}^{2}$ de área de cobertura do canal. Entretanto, após 137 dias de análises, observou-se um decréscimo de $60 \%$ da área de cobertura inicial. Novamente foram transplantados outros indivíduos saudáveis $(268 \mathrm{~kg}$ ocupando uma área de cobertura de $22 \mathrm{~m}^{2}$ do canal) e um declínio de $27 \%$ da área de cobertura foi observado.

Um banco vegetal de Pistia stratioides (alface d`água) também foi transplantado para o canal de MAFE ( $75 \mathrm{~kg}$ de alface d água ocupando uma área de cobertura de $8 \mathrm{~m}^{2}$ ). Essas macrófitas flutuantes mostraram-se em expansão no primeiro período analisado (30 de dezembro de 2003 a 03 de março de 2004) aumentando em aproximadamente $125 \%$ sua área de cobertura durante o verão. No entanto, a carência de nutrientes, o ataque de ortópteros (gafanhotos) e a queda progressiva da temperatura do ambiente provocaram o declínio total da biomassa, restando menos de $1 \mathrm{~m}^{2}$ constituído de pequenas plantas em 15 de maio de 2004 (FBDS, 2004). 
Outra macrófita flutuante testada foi Salvinia auriculata. Desta planta, foram colocados aproximadamente $15 \mathrm{~kg}$ no canal de MAFE (área de cobertura de $4 \mathrm{~m}^{2}$ ). $\mathrm{O}$ banco vegetal transplantado mostrou-se em expansão durante todo o período analisado com maior taxa de crescimento ocorrendo no verão, aumentando sua área superficial em $138 \mathrm{~m}^{2}$, ou seja, uma expansão de $3450 \%$.

A comunidade de salvinia ao final do período de teste ocupou cerca de $27 \%$ da área superficial total do canal, colonizando áreas de superfície livre e áreas de subbosque consorciando-se com outras espécies como aguapé e taboa (FBDS, 2004).
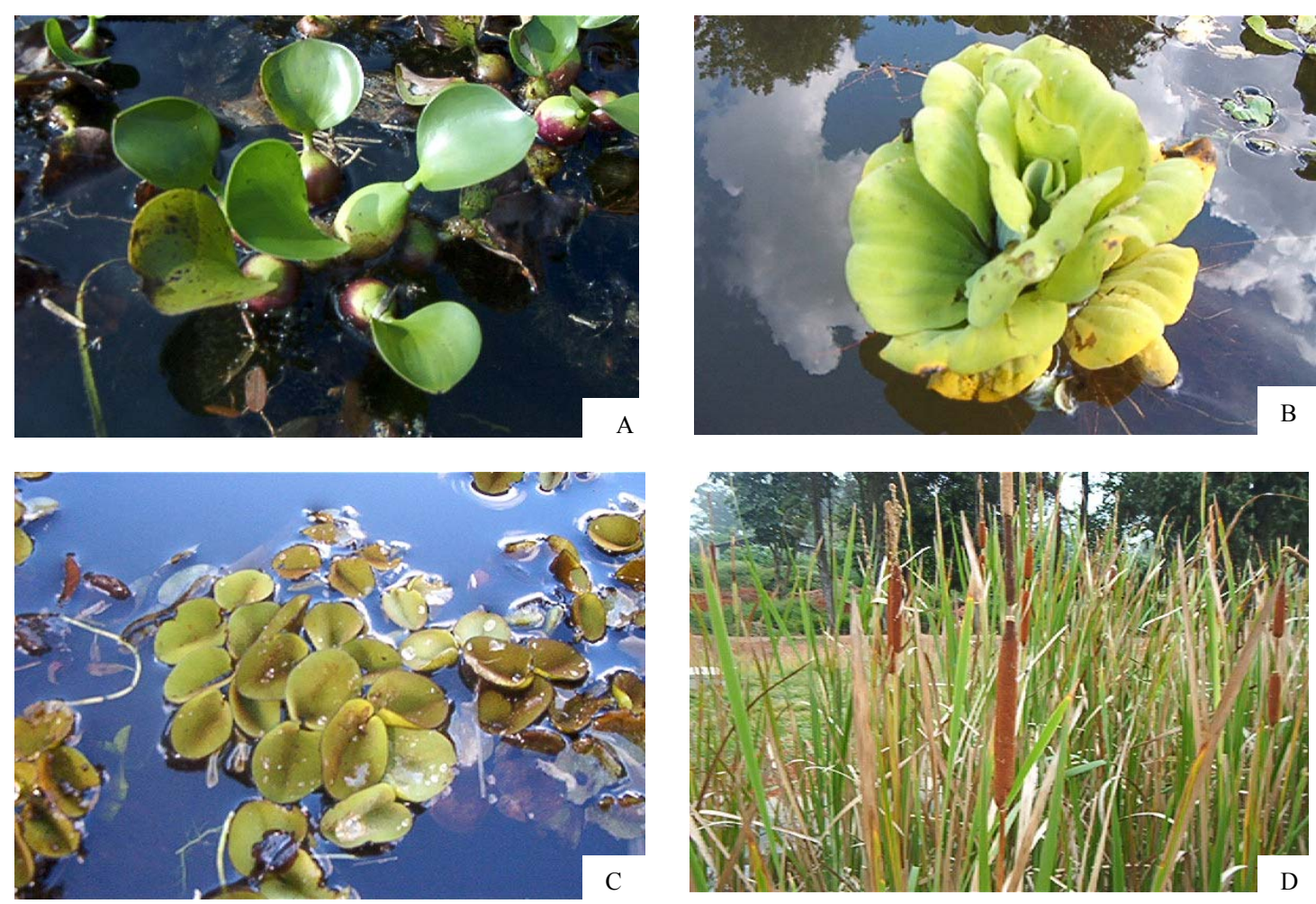

Figura 12: Plantas flutuantes (A-C) e emergentes (D) do canal de macrófitas A. Eicchornia crassipes (aguapé). B. Pistia stratiotes (alface d’água). C. Salvinia auriculata. D. Typha angustifolia. Fonte: FBDS (2004).

- $\quad$ Plantas aquáticas emergentes

Com relação às macrófitas emergentes no canal de MAFE foi testada a espécie Typha angustifólia (taboa). Cerca de 87 plantas de taboa, o equivalente a 1,5plantas $/ \mathrm{m}^{2}$, foram transplantadas para o canal. Essa macrófita mostrou-se em expansão durante todo o período analisado, aumentando o seu número de indivíduos em mais de $200 \%$.

No geral pode-se considerar uma tendência a decréscimos biométricos das plantas transplantadas durante o estagio inicial de adaptação. No entanto, o aguapé e o 
alface d’água mostraram um desenvolvimento insatisfatório no sistema, fato evidenciada pelo declínio de sua área de cobertura superficial (FBDS, 2004).

Essa observação pode ser explicada pela baixa concentração de nutrientes no efluente e exposição a períodos de baixas temperaturas, que desfavorecem o crescimento e o desenvolvimento da planta. No entanto, depois de estabelecido o consórcio entre salvinia, aguapé e pistia (Fig.13), percebeu-se uma expansão destas últimas espécies no canal de macrófitas (FBDS, 2004).

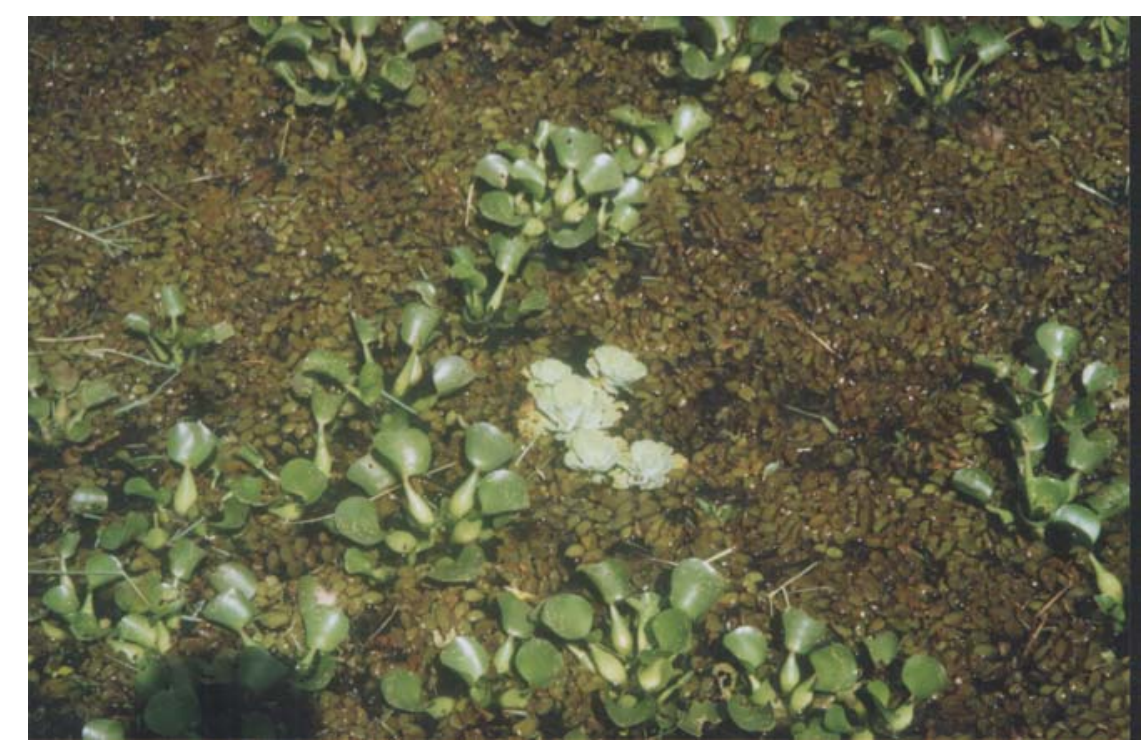

Figura 13: Foto do canal de macrófitas mostrando o consórcio aguapé, pistia e salvinia no ano de 2005.

\subsubsection{Sistema de despoluição hídrica com solos filtrantes (DHS):}

Após a passagem pelo canal MAFE, a água é conduzida para dois módulos de solos filtrantes cultivados com arroz irrigado (Oryza sativa - variedades SCS 112 ou EPAGRI 109) e composto por duas células de fluxo descendente, com uma área útil de $65 \mathrm{~m}^{2}$ cada um (Fig. 14).

O sistema possui três células de DHS, no entanto, os fluxos de água são alternados em duas das três células do módulo, de tal forma a estar sempre uma delas em processo de drenagem e pousio. A alternância é feita a cada 10 dias.

Os solos filtrantes foram projetados para funcionar com um fluxo hidráulico de até $0,5 \mathrm{~L} \cdot \mathrm{s}^{-1}$ com taxa média de aplicação $45 \mathrm{~L} \cdot \mathrm{s}^{-1} \cdot \mathrm{ha}^{-1}$.

O fluxo de entrada para os módulos é dividido em dois sistemas paralelos regulados por registros que conduzem a metade da vazão de saída do canal de MAFE para cada um dos dois solos. 

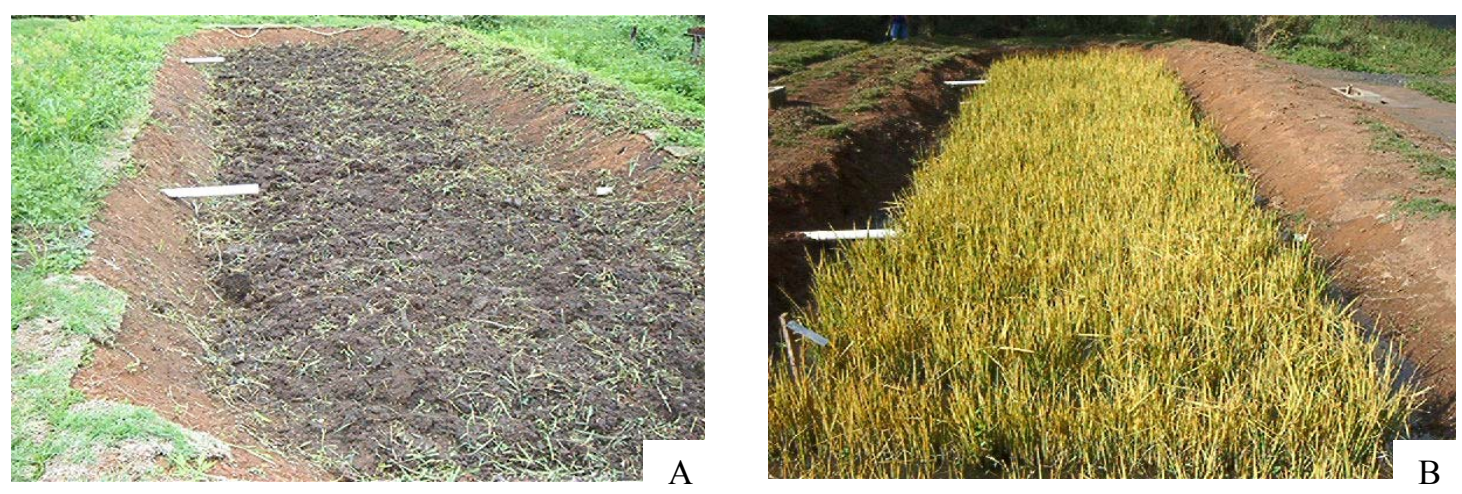

Figura 14: Módulo de solo filtrante. A. solo em preparação para semeadura de duas variedades de arroz irrigado - Oryza sativa. B. solo com 109 dias após a semeadura. Fonte: FBDS, 2004

O sistema de drenagem, assentado sobre lona impermeável, é constituído de tubos de PVC perfurados. As valas foram preenchidas com uma camada de $10 \mathrm{~cm}$ de brita no 1 ( 20 a $40 \mathrm{~mm})$ e acima desta foi colocada uma camada de $10 \mathrm{~cm}$ de pedrisco $(10$ a $20 \mathrm{~mm}$ ) e outra de $25 \mathrm{~cm}$ de substrato. O substrato, como pode ser visualizado na tabela 3, é composto por solo de textura argilosa (FBDS, 2004).

A altura da lâmina da água dentro dos módulos é controlada pelo manejo do sistema de tubos invertidos, que são responsáveis pelo controle da vazão de saída. A altura escolhida depende do estágio de crescimento da cultura de arroz irrigado, chegando a variar de 1 a $25 \mathrm{~cm}$ (FBDS, 2004).

Tabela 3: Características físicas do solo utilizado no sistema de alagados construídos (Outubro de 2003).

\begin{tabular}{ccccc}
\hline Módulos & Areia (\%) & Silte (\%) & Argila (\%) & Classe Textural \\
\hline Solo Filtrante 1 & 50 & 13 & 37 & Solo Argiloso \\
Solo Filtrante 2 & 45 & 11 & 44 & Solo Argiloso \\
Solo Filtrante 3 & 46 & 11 & 43 & Solo Argiloso \\
\hline
\end{tabular}

Fonte: FBDS, 2004

Durante o período de ensaio (30 de dezembro de 2003 a 27 de agosto de 2004), cada módulo do sistema foi preparado e semeado com duas variedades de arroz de cultivo irrigado: SCS-112 e EPAGRI-109. Foram semeadas, em média, 60 sementes por metro linear com espaçamento de $40 \mathrm{~cm}$ entre linhas em ambos os módulos.

Cerca de 30 dias antes da semeadura os solos foram preparados com o objetivo de promover maior aeração, descompactação e incorporação. Após o término dessas operações realizou-se o nivelamento e o sulcamento do solo para a semeadura. $\mathrm{O}$ arroz foi semeado no dia dois de janeiro de 2004 e a germinação e emergência da plântula aconteceu cerca dez dias depois (12/01/04), não havendo diferenças entre as duas 
variedades (FBDS, 2004). O arroz apresentou para as duas variedades testadas, um satisfatório crescimento e desenvolvimento vegetativo durante o período de estudo.

Os dados biométricos das macrófitas e os dados sobre biomassa produzida podem ser verificados no trabalho desenvolvido por Antunes ${ }^{15}$ (fase de elaboração).

As macrófitas retiradas do sistema passam por uma composteira e são utilizadas como adubo para mudas do viveiro do parque.

\subsection{Período de coleta e pontos de amostragem}

As amostras de água foram coletadas mensalmente em dois períodos distintos: fevereiro, março, junho e julho de 2004 (implantação do sistema) e de março a setembro de 2005 (um ano de funcionamento).

Com intuito de se obter dados da qualidade do efluente em todas as etapas do sistema, e conseqüentemente as eficiências parciais e totais da estação de tratamento, as coletas foram realizadas na entrada e saída de cada uma das células conforme ilustrado na figura 15.

- P1 - entrada do sistema (efluente captado na lagoa) (Fig.16);

- P2 - saída do canal de macrófitas aquáticas flutuantes e emergentes (entrada do sistema DHS) (Fig.17);

- P3 - saída final do sistema (Saída do sistema DHS) (Fig.18).

${ }^{15}$ Antunes, R. (em fase de elaboração). Dissertação (Mestrado) - Escola de Engenharia de São Carlos, Universidade de São Paulo, São Carlos. 


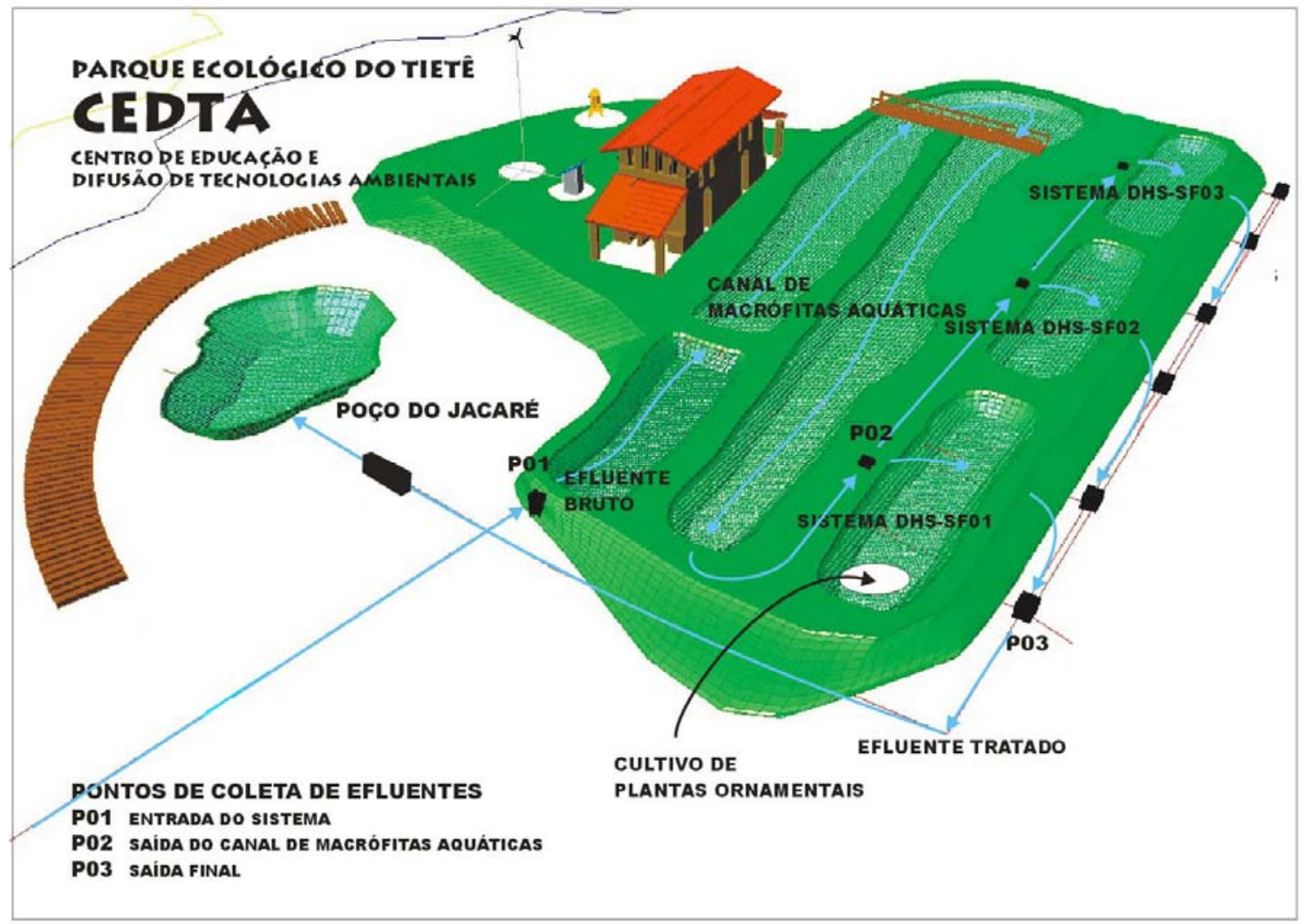

Figura 15: Esquema do sistema combinado de alagados construído implantado em 2003, ilustrando os pontos de coleta. Fonte: FBDS, 2004.

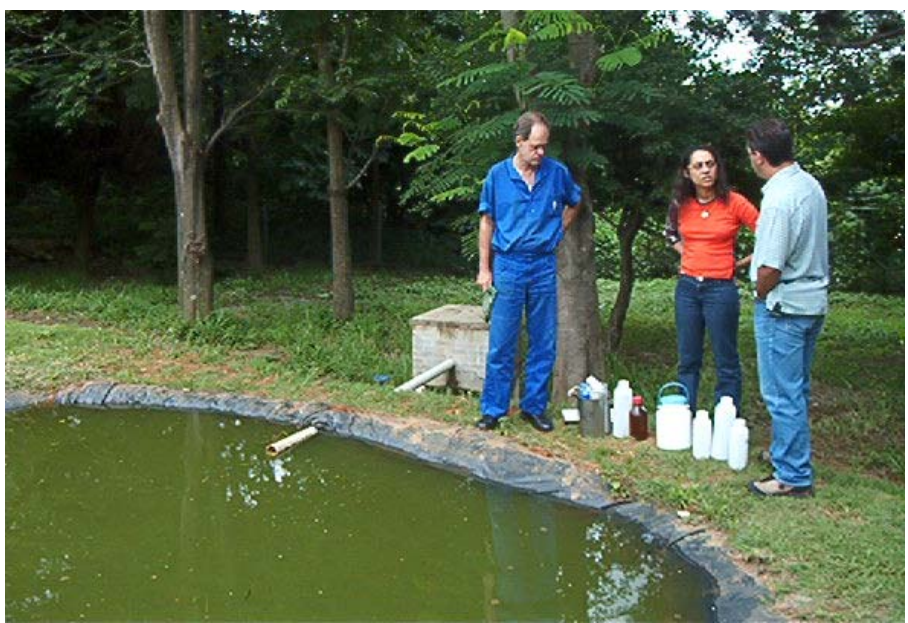

Figura 16: Entrada do sistema de wetlands construídos (P1). Fonte: FBDS, 2004. 


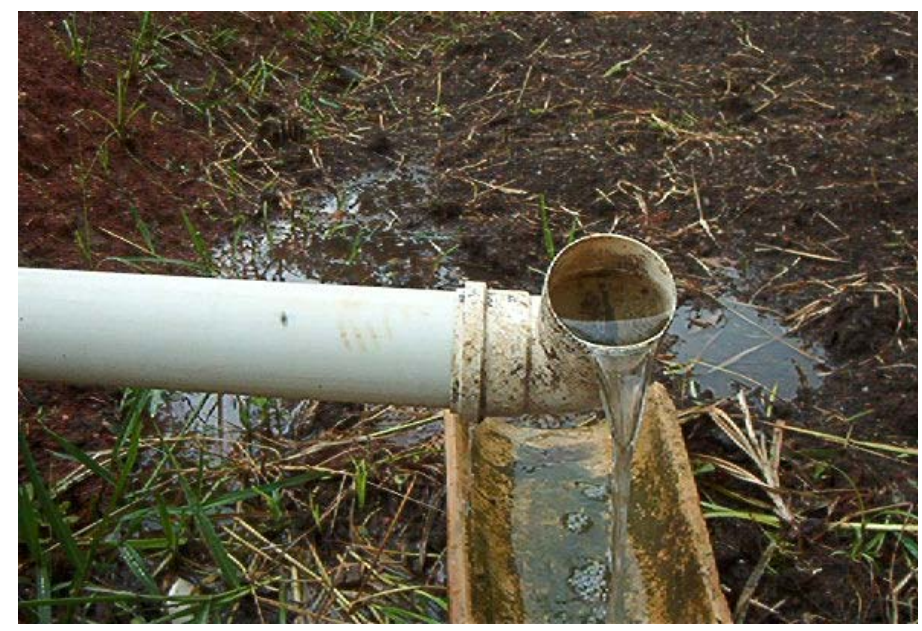

Figura 17: Saída do canal de macrófitas aquáticas flutuantes e emergentes e entrada do sistema de DHS (P2). Fonte: FBDS, 2004.

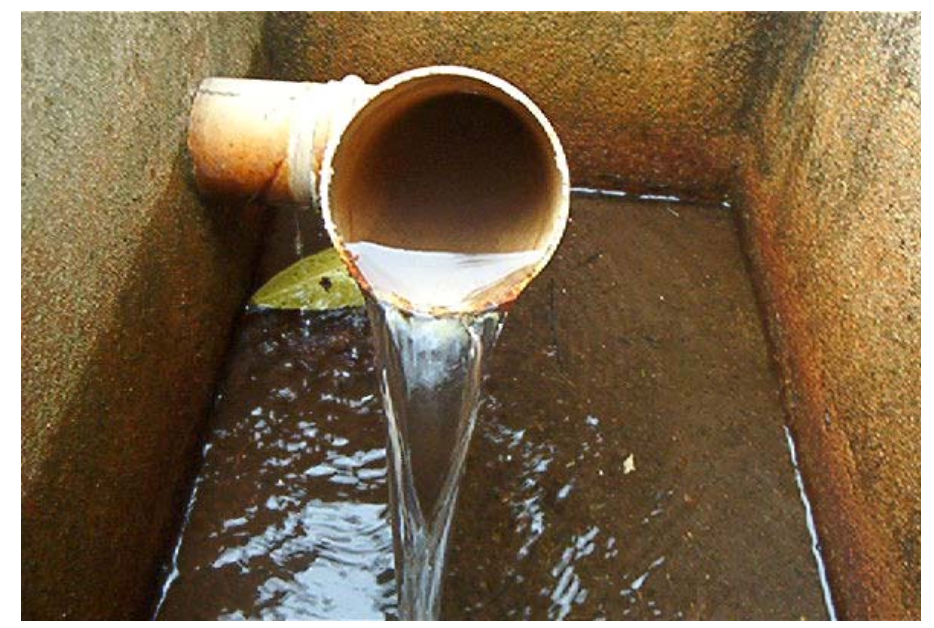

Figura 18: Saída do sistema de wetlands construídos (P3). Fonte: FBDS, 2004.

\subsection{Parâmetros analisados}

\subsubsection{Variáveis climatológicas}

Os dados de precipitação pluviométrica e de temperatura média mensal do ar, em 2004 e 2005, foram obtidos através da Estação Metereológica do Departamento de Ciências Atmosféricas do Instituto Astronômico e Geofísico da Universidade de São Paulo (IAG-USP), situada no Parque Estadual das Fontes do Ipiranga (antigo Parque do Estado) no bairro da Água Funda. Em termos de referência geográfica, a Estação Meteorológica localiza-se nas coordenadas: latitude $23^{\circ} 39^{\prime} \mathrm{S}$, longitude $46^{\circ} 37^{\prime} \mathrm{W}$ e à 800 metros de altitude em relação ao nível do mar. 
As medições, as coletas e as análises das amostras do efluente nas diversas etapas do sistema combinado de alagados construídos foram efetuadas pela SABESP.

\subsubsection{Variáveis hidrológicas}

O sistema foi monitorado através de medições hidrológicas do fluxo de entrada e saída da água $\left(\right.$ L.s $\left.{ }^{-1}\right)$ nas etapas do sistema, e da altura da lâmina d’água no canal de macrófitas e nos solos filtrantes. Através destas medições foram calculados o tempo de residência hidráulico no canal de MAFE, a taxa de aplicação nos solos filtrantes e as taxas estimadas de perda hídrica.

O tempo de residência hidráulico $(\mathrm{TRH})$ no canal de MAFE foi obtido através da fórmula:

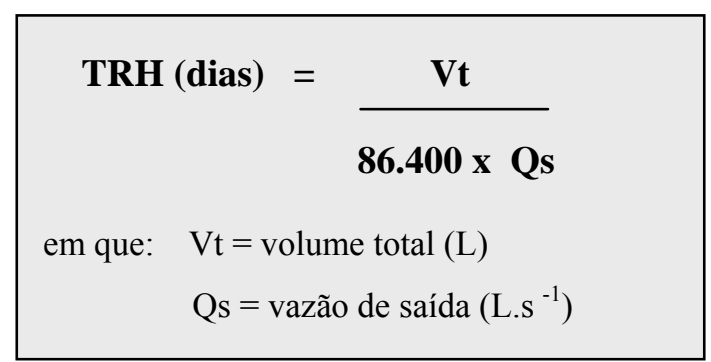

\subsubsection{Variáveis físicas e químicas da água}

Segundo a SABESP, as metodologias utilizadas em coletas e análises seguem a determinação do Ministério da Saúde, através da Portaria MS N 518 (2004), que estabelece os procedimentos e responsabilidades relativas ao controle e vigilância da qualidade da água para consumo humano e seu padrão de potabilidade, em seu artigo 17, conforme segue:

“Art. 17. As metodologias analíticas para determinação dos parâmetros físicos, químicos microbiológicos e de radioatividade devem atender as especificações das normas nacionais que disciplinem a matéria, da edição mais recente da publicação Standart Methods for the Examination of Water and Wastewater, de autoria das instituições American Public Health Association (APHA), American Water Works Association (AWWA) e Water Environment Federation (WEF), ou das normas publicadas pela ISO (International Standartization Organization).

As variáveis físicas e químicas analisadas nas várias etapas e os métodos de determinação estão apresentadas na tabela 4. As análises químicas foram realizadas pelo 
Laboratório de Inorgânicos da Divisão de Laboratório Central de Controle e Desenvolvimento (TTHL) da SABESP.

Tabela 4: Variáveis físicas e químicas analisadas e os métodos de determinação realizados pela SABESP - Laboratório de Inorgânicos.

\begin{tabular}{|c|c|c|c|c|}
\hline VARIÁVEIS & UNIDADE & MÉTODO & 2004 & 2005 \\
\hline Temperatura do ar & ${ }^{\circ} \mathrm{C}$ & \multirow{2}{*}{ Termômetro } & $\mathrm{X}$ & $\mathrm{X}$ \\
\hline Temperatura da água & ${ }^{\circ} \mathrm{C}$ & & $\mathrm{X}$ & $\mathrm{X}$ \\
\hline Oxigênio Dissolvido & $\mathrm{mg} \mathrm{O}_{2} / \mathrm{L}$ & Titulometria (Iodo) & $\mathrm{X}$ & \\
\hline $\mathrm{pH}$ & - & Potenciometria & $\mathrm{X}$ & $\mathrm{X}$ \\
\hline Alcalinidade Total & $\mathrm{mg} \mathrm{CaCO} / \mathrm{L}$ & Titulação potenciométrica & $\mathrm{X}$ & \\
\hline Dureza & $\mathrm{mg} \mathrm{CaCO} / \mathrm{L}$ & Titulometria & $\mathrm{X}$ & \\
\hline Cloreto & $\mathrm{mg} \mathrm{Cl} / \mathrm{L}$ & Cromatografia de íons & $\mathrm{X}$ & $\mathrm{X}$ \\
\hline Sulfato & $\mathrm{mg} \mathrm{SO}_{4} / \mathrm{L}$ & Cromatografia de íons & $\mathrm{X}$ & \\
\hline Condutividade Elétrica & $\mu \mathrm{mho} / \mathrm{cm}$ & Potenciometria & $\mathrm{X}$ & $\mathrm{X}$ \\
\hline Cor & $\mathrm{UC}$ & Comparação Visual (Pt/Co) & $\mathrm{X}$ & $X$ \\
\hline Turbidez & UNT & Nefelometria & $\mathrm{X}$ & $\mathrm{X}$ \\
\hline Sólidos Totais & $\mathrm{mg} / \mathrm{L}$ & Gravimetria & $\mathrm{X}$ & \\
\hline DBO & $\mathrm{mg} \mathrm{O}_{2} / \mathrm{L}$ & Respirométrico & $\mathrm{X}$ & \\
\hline DQO & $\mathrm{mg} \mathrm{O}_{2} / \mathrm{L}$ & Colorimetria & $\mathrm{X}$ & $\mathrm{X}$ \\
\hline Fósforo Total & $\mathrm{mg} \mathrm{P/L}$ & $\begin{array}{c}\text { Colorimetria } \\
\text { (Cloreto estanoso) }\end{array}$ & $\mathrm{X}$ & $X$ \\
\hline Nitrogênio Albuminóide & $\mathrm{mg} / \mathrm{L}$ & Destilação com colorimetria & $\mathrm{X}$ & \\
\hline Nitrogênio Amoniacal & $\mathrm{mg} / \mathrm{L}$ & Destilação com colorimetria & $\mathrm{X}$ & $\mathrm{X}$ \\
\hline Nitrato & $\mathrm{mg} / \mathrm{L}$ & Cromatografia de íons & $\mathrm{X}$ & \\
\hline Nitrito & $\mathrm{mg} / \mathrm{L}$ & Cromatografia de íons & $\mathrm{X}$ & \\
\hline Bário & $\mathrm{mg} \mathrm{Ba} / \mathrm{L}$ & \multirow{10}{*}{$\begin{array}{l}\text { Absorção atômica } \\
\text { (Espectrofotômetro) }\end{array}$} & $\mathrm{X}$ & $\mathrm{X}$ \\
\hline Cádmio & $\mathrm{mg} \mathrm{Cd} / \mathrm{L}$ & & $\mathrm{X}$ & \\
\hline Chumbo & $\mathrm{mg} \mathrm{Pb/L}$ & & $\mathrm{X}$ & \\
\hline Cobre & $\mathrm{mg} \mathrm{Cu} / \mathrm{L}$ & & $\mathrm{X}$ & $\mathrm{X}$ \\
\hline Cromo & $\mathrm{mg} \mathrm{Cr} / \mathrm{L}$ & & $\mathrm{X}$ & $\mathrm{X}$ \\
\hline Ferro Total & $\mathrm{mg} \mathrm{Fe} / \mathrm{L}$ & & $\mathrm{X}$ & $\mathrm{X}$ \\
\hline Manganês total & $\mathrm{mg} \mathrm{Mn} / \mathrm{L}$ & & $\mathrm{X}$ & $\mathrm{X}$ \\
\hline Mercúrio & $\mathrm{mg} \mathrm{Hg} / \mathrm{L}$ & & $\mathrm{X}$ & $\mathrm{X}$ \\
\hline Prata & $\mathrm{mg} \mathrm{Ag} / \mathrm{L}$ & & $\mathrm{X}$ & $X$ \\
\hline Zinco & $\mathrm{mg} \mathrm{Zn/L}$ & & $\mathrm{X}$ & $X$ \\
\hline Fenol & mg Fenol/L & $\begin{array}{l}\text { Extração com colorimetria } \\
\text { (ferricianeto de potássio) }\end{array}$ & & $X$ \\
\hline
\end{tabular}

\subsubsection{Variáveis biológicas da água}

As análises dos coliformes totais e termotolerantes foram realizadas pelo Laboratório de Microbiologia da Divisão de Laboratório Central de Controle e Desenvolvimento (TTHL) da SABESP. O método utilizado foi o do substrato cromogênico - COLILERT IDEXX (APHA, 1998). 


\subsection{Cálculo das Taxas de Eficiência de Remoção}

\subsubsection{Taxa de Eficiência de Remoção Total}

A taxa de eficiência de remoção total avaliada no sistema de alagados foi calculada pela diferença entre as concentrações na entrada (P1) e na saída do sistema (P3), dividida pela concentração medida entrada, e finalmente multiplicada por 100 (para ser expressa em porcentagem).

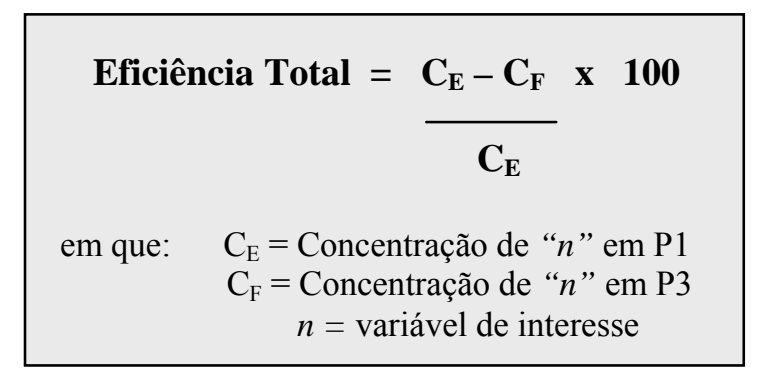

\subsubsection{Taxa de Eficiência de Remoção Parcial}

A taxa de eficiência de remoção do canal de MAFE foi calculada pela diferença entre as concentrações na entrada do sistema (P1) e na saída do canal de macrófitas aquáticas (P2), dividida pela concentração medida na entrada da célula e multiplicada por 100 (valor em porcentagem).

Para a eficiência de remoção dos solos filtrantes, foi utilizado o mesmo procedimento, no entanto com a variável analisada na entrada e na saída dos módulos do sistema DHS (P2 e P3, respectivamente).

\subsection{Interpretação dos dados}

Para interpretação e análise dos resultados foram realizadas análises exploratórias multivariadas (MANOVA) e univariadas (ANOVA-SAS), além dos testes de hipótese sobre o conjunto de dados.

Os resultados obtidos na análise das variáveis na saída do sistema de tratamento foram também comparados com as condições e padrões de qualidade da água para águas doces classe 2 segundo a Resolução CONAMA 357 de 2005 (BRASIL, 2005).

Os valores medidos para cada variável nos períodos de coleta e os valores limites estabelecidos para águas de classe 2, segundo o CONAMA 357/2005 (BRASIL, 
2005) e os dados de desvio padrão podem ser visualizados no Apêndice A (Tabelas 35 a 42)

As taxas de eficiência parcial e total do sistema estão representadas no Apêndice B (Tabelas de 43 a 48).

\subsubsection{Análises Estatísticas}

\subsubsection{MANOVA e Testes de hipótese}

Foram realizadas no trabalho, de acordo com a disponibilidade dos dados, três análises de variância multivariada (MANOVA) seguidas pelos testes de hipótese.

A primeira análise foi realizada sobre a matriz 2004/05 contendo os meses (março, junho e julho) e variáveis limnológicas em comum aos dois anos de estudo: temperatura da água; $\mathrm{pH}$, cloreto, condutividade elétrica, cor, turbidez, cloreto, DQO, fósforo total, nitrogênio amoniacal, ferro total, manganês total. Para este conjunto de dados, testou-se os anos de coleta para verificar se havia variabilidade anual (sob a condição de nível significância de $5 \%$ - $\mathrm{p}<0,05)$.

A segunda análise foi realizada sobre a matriz de dados de 2004 contendo as variáveis limnológicas: temperatura da água, oxigênio dissolvido, $\mathrm{pH}$, alcalinidade, dureza, cloreto, sulfato, condutividade elétrica, cor, turbidez, sólidos totais, DBO, DQO, fósforo total, nitrogênio albuminóide, nitrogênio amoniacal, cádmio, chumbo, ferro total, manganês total, coliformes totais e coliformes termotolerantes. Para este conjunto de dados, testou-se o efeito da remoção entre os pontos 1, 2 e 3 para verificar se havia diferença estatística entre os mesmos $(p<0,05)$.

A última análise multivariada foi realizada sobre a matriz de dados de 2005, contendo as variáveis limnológicas: temperatura da água; $\mathrm{pH}$, cloreto, condutividade elétrica, cor, turbidez, cloreto, DQO, fósforo total, nitrogênio amoniacal, ferro total, manganês total e fenol. Para este conjunto de dados, testou-se o efeito da remoção entre os pontos 1, 2 e 3 para verificar se havia diferença estatística entre os mesmos $(p<0,05)$.

\subsubsection{SAS e Teste de Tukey}

Os dados foram analisados através do programa estatístico SAS, que possibilitou a observação dos comportamentos das variáveis limnológicas consideradas, em relação aos pontos de coleta. O Teste de Tukey foi utilizado para verificar a possível existência de diferença entre as concentrações médias nos pontos de coleta. O Teste de Tukey é 
baseado na amplitude total estudentizada (studentized range). $\mathrm{O}$ conjunto de dados utilizado foi o mesmo da análise multivariada e testes de hipótese.

Com a aplicação do teste estatístico SAS e do Teste de Tukey, observou-se as variações, ao nível de 5\% de significância, para cada parâmetro.

\section{RESULTADOS E DISCUSSÃO}

Na análise de variância multivariada (MANOVA) realizada sobre a matriz 2004/05, composta por doze variáveis e pelos meses de março, junho e julho, testou-se o efeito interanual (ano 2004 e 2005) sobre o conjunto de dados (Apêndice C).

Como resultado, verificou-se que há uma diferença significativa entre os anos de 2004 e 2005 com um nível de significância de 5\% (p=0,022). Resultado que está de acordo com o que diz a literatura para o período de estabilização do sistema e o comportamento do mesmo nos dois anos de monitoramento.

Desta forma, optou-se por analisar as matrizes dos dados em função do ano de 2004 e de 2005 separadamente.

O período inicial de um sistema de alagado construído envolve o plantio e preenchimento do canal e solos com as macrófitas, e é um momento em que os solos, as plantas e os microrganismos se adaptam as condições hidrológicas do sistema. Os alagados construídos, assim como todos os sistemas, são capazes de tolerar melhor as mudanças, se tiverem tempo para se estabilizar; e por isso, durante o período de estudo, foi utilizada uma vazão menor do que a calculada para elaboração do projeto (KADLEC et al., 2000).

Apesar de alguns processos de remoção necessitarem de apenas alguns meses para se estabilizar, outros podem requerer de meses a anos. A vegetação e o biofilme levam de 1 a 2 anos para se estabelecerem em alagados de fluxo superficial. Já os processos de adsorção e lixiviação do alagado de fluxo subsuperficial podem necessitar de um ano ou mais para alcançar um equilíbrio (KADLEC et al., 2000).

Quando o solo é inundado, uma série de alterações é desencadeada e é caracterizado pelo aparecimento de uma cor mais escura e um baixo potencial redox do solo (REDDY \& D`ANGELO, 1994).

O longo hidroperíodo dos wetlands construídos para tratamento de água é proveitoso para o estabelecimento dos orgânicos: primeiramente a matéria orgânica morta (litter) e os microdetritos, depois o sedimento formado pela decomposição destes, 
e finalmente, os solos orgânicos originados por esse sedimento juntamente com a deposição de sólidos minerais (KADLEC et al., 2000).

Com relação às plantas, elas têm que se adequar a qualidade da água, se desenvolverem e preencherem o canal. Um período pequeno de 3 a 4 meses ou de até 2 anos pode ser necessário para cobertura completa do alagado. Durante o período de estudo, cerca de 14 meses após o plantio, o canal já estava totalmente preenchido. No entanto, o desenvolvimento do sistema de raiz e rizoma pode necessitar de mais de uma estação de crescimento, cerca de 3 a 5 anos para se completar (KADLEC et al., 2000).

Segundo estes autores, durante o período inicial de um sistema de alagado construído, as condições antecedentes são importantes porque regem o desempenho do alagado em curto prazo (dois anos). O funcionamento do alagado após esta adaptação não será então mais dependente das condições anteriores do tipo de solo, hidrologia e biota, vai ser totalmente dependente dos novos solos formados, da hidrologia e da biota que se adaptaram a esse tipo de sistema.

Apesar de o trabalho ter sido desenvolvido durante o período de estabilização do sistema, é importante notar que são dois períodos distintos, uma vez que durante o primeiro ano de operação (2004), as macrófitas estavam sendo testadas, com a não adaptação inicial de certas plantas (aguapé e alface d’água) e aumento conseqüente da taxa de matéria orgânica em decomposição; o canal e os solos filtrantes não estavam ainda totalmente preenchidos de macrófitas (fase de crescimento); os solos (MAFE e DHA) estavam sofrendo as alterações iniciais ao serem saturados com água e o biofilme estava no início do seu desenvolvimento.

$\mathrm{Na}$ análise de variância multivariada (MANOVA), realizada sobre a matriz 2004 composta por vinte variáveis, testou-se o efeito da remoção pelas etapas do sistema sobre o conjunto de dados (Apêndice D) para verificar se houve diferença estatística entre os pontos 1, 2 e 3 (nível de significância de 5\%). No entanto, em função da multicolinearidade dos dados, optou-se pelas análises univariadas (ANOVA).

Para o conjunto de dados de 2005 (Apêndice E), composto por treze variáveis abióticas, admitindo-se que o nível de corte de probabilidade aceito foi de 5\%, os resultados indicaram que as etapas do sistema foram significativas na remoção das variáveis para esse conjunto de dados $(\mathrm{p}=0,000)$.

Com a análise univariada (ANOVA - SAS) para cada variável em cada período de estudo seguida do teste de Tukey, observou-se uma diferença significativa das 
concentrações médias de algumas variáveis, entre os pontos de coleta, tanto para 2004 quanto para 2005.

No ano de 2004, remoções significativas foram observadas para as variáveis dureza, sulfato, cor, turbidez, DQO, fósforo total, nitrogênio albuminóide após a passagem pelo sistema de alagados construídos.

Para o período de estudo de 2005, além das variáveis citadas para 2004 (cor, turbidez, DQO e fósforo total), remoções significativas para nitrogênio amoniacal e manganês total também foram verificadas.

Os resultados do teste de Tukey estão apresentados no decorrer do texto (valores médios de cada variável para pontos de amostragem). As letras presentes ao lado de cada média são indicativas. Médias seguidas por letras diferentes diferem significativamente ao nível $\alpha=5 \%$. A melhor forma para ler é sempre olhando os grupos que formam os grupos de médias, como por exemplo, com a letra (A) e os grupos de (B). Quando as letras (AB) aparecem juntas, significa que aquela média pertence tanto ao Grupo (A) e quanto ao Grupo(B).

Durante o período de estudo, não houve manejo no sistema e por isso, acreditase que taxas maiores de remoção poderiam ter sido alcançadas se tivessem sido realizadas colheitas periódicas das macrófitas e houvesse a alternância de funcionamento dos solos filtrantes.

O manejo adequado no canal de macrófitas consiste na retirada de uma parte das plantas aquáticas que cobrem totalmente o sistema. Desta forma, evita-se que haja um retorno da maioria dos nutrientes assimilados para a coluna d’água com a morte e decomposição das plantas. Além disso, serão liberadas superfícies livres para incidência de raios ultravioleta (reduzir os coliformes) e difusão do oxigênio atmosférico para a água. Com o aumento de oxigênio na água serão otimizados os processos aeróbios de remoção: decomposição, nitrificação, oxidação de metais, precipitação e co-precipitação com hidróxidos de ferro e manganês.

A alternância do funcionamento das células de 10 a 15 dias, é necessária para evitar a colmatação do solo e permitir a aeração do sistema DHS. Durante os períodos de aplicação do efluente, ocorre a saída do ar do solo, enquanto que no período de pousio e drenagem, o ar atmosférico é movido para dentro dos espaços intersticiais do solo, aumentando assim a sua oxigenação (SALATI, 1998). No período de estudo, não foi realizada esta alternância e o que se observou foi uma baixa concentração de 
oxigênio dissolvido no efluente e um baixo desempenho dos solos nos processos aeróbios.

\subsection{Variáveis climatológicas}

\subsubsection{Precipitação pluviométrica}

Os valores totais mensais de precipitação pluviométrica em cada mês do ano de 2004 e 2005 podem ser visualizados na tabela 5.

Tabela 5: Variação dos valores mensais de precipitação pluviométrica (mm) no Parque Estadual de Água Funda durante o ano de 2004 e 2005. Os valores em destaque correspondem aos meses de coleta.

\begin{tabular}{|c|c|c|c|c|c|c|c|c|c|c|c|c|}
\hline & \multicolumn{12}{|c|}{ Precipitacão Mensal (mm) } \\
\hline & Jan & Fev & Mar & Abr & Mai & Jun & Jul & Ago & Set & Out & Nov & Dez \\
\hline 2004 & 209,7 & 269,8 & 158,6 & 191,9 & 87,1 & 70,5 & 102,4 & 2,8 & 23,5 & 110,1 & 289,6 & 223,9 \\
\hline 2005 & 385,8 & 79 & 103,5 & 82,6 & 174,7 & 23,1 & 18,3 & 7,3 & 143,2 & 162,7 & 92,8 & 188,6 \\
\hline
\end{tabular}

Fonte: Estação Meteorológica do IAG/USP.

É possível observar que a maior precipitação, no período de estudo em 2004, ocorreu no mês de fevereiro seguido pelo de março, como era esperado, enquanto que os meses de junho e julho apresentaram uma menor precipitação.

No ano de 2005, a maior precipitação mensal ocorreu nos meses de maio, setembro e março, enquanto que a menor nos meses de agosto, junho e julho. Pode-se dizer que o mês de abril apresentou uma média de precipitação intermediária em relação aos demais meses de estudo.

A partir de uma análise da média histórica de chuvas (1933 a 2002) para a região (IAG/USP), os meses de outubro a março correspondem à estação chuvosa enquanto que os meses de abril a setembro, à seca. A variação dos valores mensais de precipitação pluviométrica durante os anos de coleta e a média mensal histórica (19332002) podem ser visualizadas na figura 19. 
2004

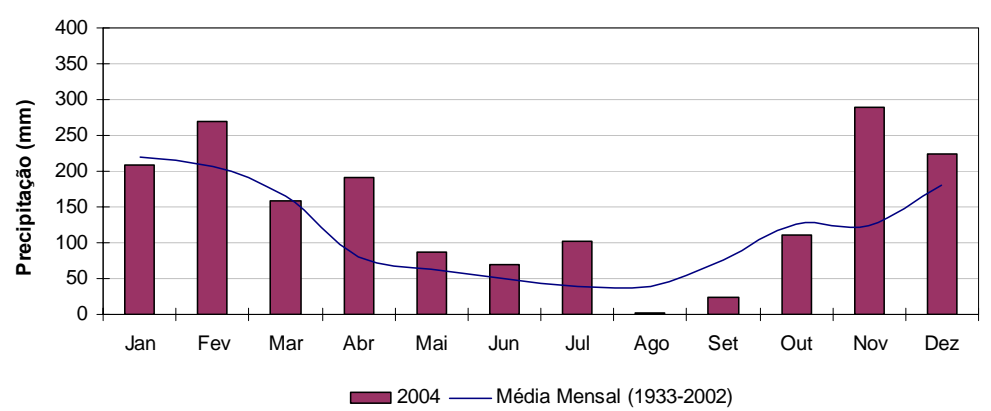

2005

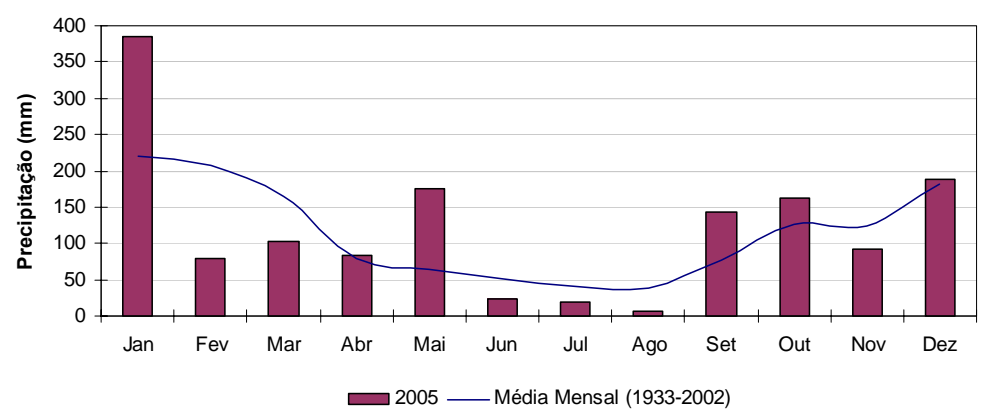

Figura 19: Variação dos valores mensais de precipitação pluviométrica $(\mathrm{mm})$ no Parque Estadual de Água Funda durante o ano de 2004 e 2005 e a média mensal histórica. Fonte: Estação Meteorológica do $\mathrm{IAG} / \mathrm{USP}$.

Ao se comparar a precipitação dos meses de estudo de 2004 com a precipitação média de referência, foi verificado um aumento na quantidade de chuvas principalmente nos meses de fevereiro e julho.

Com relação aos dados obtidos nos meses de coleta de 2005, pode-se dizer que houve um aumento na quantidade de chuvas em maio e setembro, e uma diminuição nos meses de junho, julho e agosto. Não existiu neste ano uma estação chuvosa e seca bem definida.

Apesar do aumento da precipitação pluviométrica em determinados meses de 2004, durante os dias de coleta deste ano não houve ocorrência de chuvas. Com relação ao ano de 2005, foi observada a presença de chuvas fortes na coleta de março e de chuvas fracas na de julho, como pode ser observado na tabela 6 . 
Tabela 6: Variação dos valores de precipitação diária $(\mathrm{mm})$ durante o período de coleta no Parque Estadual de Água Funda. Os valores em destaque correspondem aos dias de coleta.

\begin{tabular}{|c|c|c|c|c|c|c|c|c|c|c|c|}
\hline \multicolumn{12}{|c|}{ Precipitação diária no período de coleta $(\mathrm{mm})$} \\
\hline \multicolumn{3}{|c|}{ Fevereiro/2004 } & \multicolumn{3}{|c|}{ Março/2004 } & \multicolumn{3}{|c|}{ Junho/2004 } & \multicolumn{3}{|c|}{ Julho/2004 } \\
\hline $10 / 02$ & $11 / 02$ & $12 / 02$ & $30 / 03$ & $31 / 03$ & $1 / 04$ & $14 / 06$ & $15 / 06$ & $16 / 06$ & $5 / 07$ & $6 / 07$ & $7 / 07$ \\
\hline 0,1 & 0 & 1,5 & 0 & 0 & 0 & 0 & 0 & 0 & 0 & 0 & 0 \\
\hline \multicolumn{3}{|c|}{ Março/2005 } & \multicolumn{3}{|c|}{ Abril/2005 } & \multicolumn{3}{|c|}{ Maio/2005 } & \multicolumn{3}{|c|}{ Junho/2005 } \\
\hline $17 / 03$ & $18 / 03$ & $19 / 03$ & $14 / 04$ & $15 / 04$ & $16 / 04$ & $12 / 05$ & $13 / 05$ & $14 / 05$ & $09 / 06$ & $10 / 06$ & $11 / 06$ \\
\hline 13,2 & 7,6 & 0 & 0 & 0 & 0 & 0 & 0 & 0 & 0 & 0 & 0 \\
\hline \multicolumn{3}{|c|}{ Julho/2005 } & \multicolumn{3}{|c|}{ Agosto/2005 } & \multicolumn{3}{|c|}{ Setembro/2005 } & & & \\
\hline $07 / 07$ & $08 / 07$ & $09 / 07$ & $11 / 08$ & $12 / 08$ & $13 / 08$ & $08 / 09$ & $09 / 09$ & $10 / 09$ & & & \\
\hline 0,4 & 1,1 & 0,1 & 0,1 & 0 & 0 & 0 & 0 & 0 & & & \\
\hline
\end{tabular}

Fonte: Estação Meteorológica do IAG/USP.

\subsubsection{Temperatura do ar}

A variação dos valores da temperatura do ar nos dias de coleta e a média mensal obtida junto ao IAG/USP em 2004 e 2005 estão representadas na figura 20.

Com relação à temperatura do ar em 2004, o maior valor encontrado durante as coletas foi em março $\left(24^{\circ} \mathrm{C}\right)$ e o menor em junho $\left(13^{\circ} \mathrm{C}\right)$. Na coleta de fevereiro e de julho, a temperatura do ar registrada foi de $21^{\circ} \mathrm{C}$ e $19^{\circ} \mathrm{C}$ respectivamente. Contudo, segundo as médias mensais de temperatura do ar, o mês de coleta considerado mais quente em 2004 foi o de fevereiro $\left(20,8^{\circ} \mathrm{C}\right)$ e o mais frio, o de julho $\left(15,3^{\circ} \mathrm{C}\right)$. Os meses de março e junho apresentaram médias mensais de $20,3^{\circ} \mathrm{C}$ e $16^{\circ} \mathrm{C}$ respectivamente (IAG-USP).

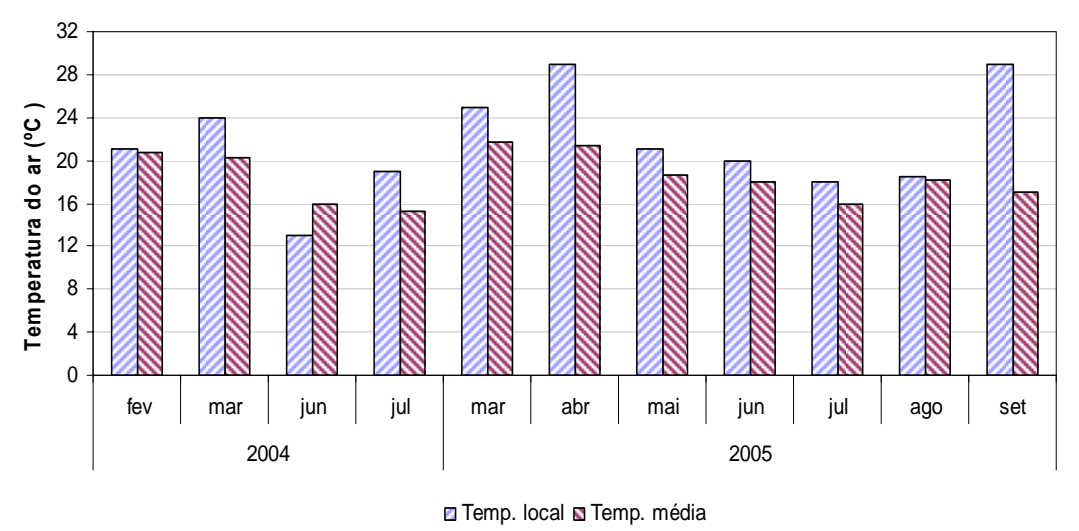

Figura 20: Variação dos valores de temperatura na hora da coleta e de temperatura média mensal do ar em 2004 e 2005. Fonte: FBDS (2004) e Estação Meteorológica do IAG/USP.

No período de coleta do ano de 2005, o maior valor de temperatura do ar encontrado foi em abril e setembro $\left(29^{\circ} \mathrm{C}\right)$ e o menor em julho $\left(18^{\circ} \mathrm{C}\right)$. No entanto, segundo as médias mensais de temperatura do ar, o mês de coleta considerado mais 
quente em 2005 foi o de março $\left(21,7^{\circ} \mathrm{C}\right)$. O mês com média de temperatura mais baixa corresponde, assim como o da coleta, ao de julho $\left(16^{\circ} \mathrm{C}\right)$ (IAG-USP).

\subsection{Variáveis hidrológicas}

Os dados das diversas variáveis hidrológicas, durante o período de fevereiro a agosto de 2004, nas diferentes etapas do sistema de alagados construídos estão representados na tabela 7 .

Tabela 7: Dados das variáveis hidrológicas nas diferentes etapas do sistema durante o período de estudo de 2004.

\begin{tabular}{|c|c|c|c|}
\hline \multicolumn{2}{|c|}{ Balanço Hídrico 2004} & Valores Médios & unid. \\
\hline \multicolumn{2}{|c|}{ Vazão de entrada do sistema (P1) } & 0,139 & L.s ${ }^{-1}$ \\
\hline \multicolumn{2}{|c|}{ Vazão de saída do Canal Macrófitas (P2) } & 0,137 & L.s ${ }^{-1}$ \\
\hline \multicolumn{2}{|c|}{ Taxa de Perda Parcial (P1-P2) } & 1,4 & $\%$ \\
\hline \multicolumn{2}{|c|}{ Vazão de Saída Solo filtrante (P3) } & 0,126 & ${\mathrm{~L} . \mathrm{S}^{-1}}^{-1}$ \\
\hline \multicolumn{2}{|c|}{ Taxa de Perda Parcial (P2-P3) } & 8 & $\%$ \\
\hline \multicolumn{2}{|c|}{ Taxa de Perda Total (P1-P3) } & 9,4 & $\%$ \\
\hline \multicolumn{2}{|c|}{ Volume (Decantação + Canal de MAFE) } & 482 & $\mathrm{~m}^{3}$ \\
\hline \multirow{2}{*}{$\begin{array}{c}\text { Altura da } \\
\text { Lâmina d'água do } \\
\text { canal de MAFE }\end{array}$} & Mínima & 70 & \multirow[b]{2}{*}{$\mathrm{cm}$} \\
\hline & Máxima & 72 & \\
\hline \multicolumn{2}{|c|}{ Altura da Lâmina d`água do Solo filtrante } & 8 & $\mathrm{~cm}$ \\
\hline \multicolumn{2}{|c|}{ Tempo de Retenção Hidráulico nos Canais } & 40,7 & dias \\
\hline \multicolumn{2}{|c|}{ Taxa de aplicação nos solos } & 9,7 & L.s. $^{-1} \cdot$ ha. $^{-1}$ \\
\hline
\end{tabular}

Fonte: FBDS (2004).

Os resultados obtidos, durante o monitoramento hidrológico do alagado construído em 2004 indicam que a vazão média de entrada no sistema foi de 0,139 L.s e a vazão média de saída do canal de MAFE foi de $0,137 \mathrm{~L} \cdot \mathrm{s}^{-1}$. Com taxa de perda parcial de 1,4\%. A altura mínima da lâmina d’água foi de $70 \mathrm{~cm}$ enquanto que a máxima foi de $72 \mathrm{~cm}$. O Tempo de Retenção Hidráulico médio do efluente no tanque de decantação e canal de macrófitas durante o período de estudo foi de 41 dias.

Com relação ao sistema de solos filtrantes, a vazão média de entrada nos módulos foi de $0,137 \mathrm{~L} .{ }^{-1}$, com uma taxa de aplicação média de $9,7{\mathrm{~L} . \mathrm{s}^{-1}}$ ha. $^{-1}$. A taxa de perda parcial foi de $8 \%$. A altura média da lâmina d’água mantida nos solos filtrantes foi de aproximadamente $8 \mathrm{~cm}$.

Durante o estudo, houve uma perda hídrica total de $9,4 \%$.

Os dados das variáveis hidrológicas, durante o período de março a setembro de 2005, nas diferentes etapas do sistema de alagados podem ser visualizados na tabela 8 . 
Tabela 8: Dados das variáveis hidrológicas nas diferentes etapas do sistema durante o período de estudo de 2005.

\begin{tabular}{|c|c|c|c|}
\hline \multicolumn{2}{|c|}{ Balanço Hídrico 2005} & Valores Médios & unid \\
\hline \multicolumn{2}{|c|}{ Vazão de entrada do sistema (P1) } & 0,137 & L.s ${ }^{-1}$ \\
\hline \multicolumn{2}{|c|}{ Vazão de saída do Canal Macrófitas (P2) } & 0,135 & L.s ${ }^{-1}$ \\
\hline \multicolumn{2}{|c|}{ Taxa de Perdas Parcial (P1-P2) } & 1,5 & $\%$ \\
\hline \multicolumn{2}{|c|}{ Vazão de Saída Solo filtrante (P3) } & 0,126 & L.s ${ }^{-1}$ \\
\hline \multicolumn{2}{|c|}{ Taxa de Perdas Parcial (P2-P3) } & 6,6 & $\%$ \\
\hline \multicolumn{2}{|c|}{ Taxas de Perdas Totais (P1-P3) } & 8 & $\%$ \\
\hline \multicolumn{2}{|c|}{ Volume (Decantação + Canal de MAFE) } & 482 & $\mathrm{~m}^{3}$ \\
\hline \multirow{2}{*}{$\begin{array}{c}\text { Altura da } \\
\text { Lâmina d`água do } \\
\text { canal de MAFE }\end{array}$} & Mínima & 70 & \multirow{2}{*}{$\mathrm{cm}$} \\
\hline & Máxima & 72 & \\
\hline \multicolumn{2}{|c|}{ Altura da Lâmina d’água do Solo filtrante } & 8 & $\mathrm{~cm}$ \\
\hline \multicolumn{2}{|c|}{ Tempo de Retenção Hidráulico nos Canais } & 41,3 & dias \\
\hline \multicolumn{2}{|c|}{ Taxa de aplicação nos solos } & 9,6 & dias \\
\hline
\end{tabular}

Os resultados obtidos, durante o monitoramento hidrológico do alagado construído em 2004 indicam que a vazão média de entrada no sistema foi de 0,137 L.s e a vazão média de saída foi de 0,135 L.s ${ }^{-1}$. Com taxa de perda parcial de 1,5\%. A altura mínima da lâmina d’água foi de $70 \mathrm{~cm}$ enquanto que a máxima foi de $72 \mathrm{~cm}$. O Tempo de Retenção Hidráulico médio do efluente no conjunto canal de decantação e de macrófitas durante o período de estudo foi de 41 dias.

Com relação ao sistema de solos filtrantes, a vazão média de entrada nos módulos foi de $0,135 \mathrm{~L} . \mathrm{s}^{-1}$, com uma taxa de aplicação média de 9,6 L.s ${ }^{-1}$ ha. $^{-1}$. A taxa de perda parcial foi de $6,6 \%$. A altura média da lâmina d’água mantida nos solos filtrantes foi de aproximadamente $8 \mathrm{~cm}$. Como a vazão trabalhada no estudo foi menor do que a projetada para o sistema $\left(0,5 \mathrm{~L} \cdot \mathrm{s}^{-1}\right)$, não se atingiu a variação de $1 \mathrm{a} 26 \mathrm{~cm}$ recomendada.

Durante o estudo, houve uma perda hídrica total de $8 \%$.

O tempo de retenção hidráulico do canal de decantação e de macrófitas (média de 41 dias), durante o período de estudo, foi maior do que o estipulado no projeto (média 9 dias) devido a taxa de vazão de entrada do sistema que foi regulada abaixo do valor proposto de $0,5 \mathrm{~L} \cdot \mathrm{s}^{-1}$. Por causa da menor taxa de vazão, não se atingiu a variação de 1 a $26 \mathrm{~cm}$ recomendada nos solos e a taxa de aplicação média também foi mais baixa.

Segundo Kadlec e colaboradores (2000), devido à estreita relação entre a performance do sistema (para quase todas as variáveis limnológicas) e a taxa de aplicação recomenda-se que a taxa de aplicação inicial do sistema de tratamento seja regulada abaixo dos valores recomendados no projeto conceitual. Esta medida visa alcançar melhores resultados de eficiência no período inicial de funcionamento do sistema e proporcionar melhores condições para estabilização da biota. 
As perdas hídricas nos canais podem ser atribuídas aos processos de evaporação e evapotranspiração no sistema wetlands, onde em geral para aquelas condições (superfície de água livre e agrupamentos de plantas aquáticas), perdas de 1,0 a 2,5\% são consideradas aceitáveis (FBDS, 2004). Já no sistema DHS entre os pontos de entrada e saída dos solos filtrantes houve, em média, perdas superiores à $6 \%$, indicando que além das perdas por processos naturais (evaporação e evapotranspiração), ocorreram perdas por infiltração (FBDS, 2004).

Outros sistemas combinados de alagados construídos apresentaram uma perda hídrica superior à encontrada no estudo. Como exemplo pode-se citar a estação para tratamento de água de Analândia, com registro de 18\% (ELIAS, 2003) e a estação para tratamento de esgoto do SEMAE de Piracicaba (NOGUEIRA, 2003), com uma média de 42 a 55\%. Cecconello (2005), ao trabalhar com tratamento de percolados de aterro sanitário com canais de macrófitas emergentes, verificou uma perda hídrica que variou de 10,8 a $16,3 \%$.

\subsection{Variáveis físicas e químicas da água}

\subsubsection{Temperatura da água}

A variação dos valores de temperatura da água no período de coletas e nas etapas do sistema de alagados em 2004 e 2005 está representada na figura 21.

Os maiores valores de 2004 foram obtidos no mês de março, seguidos pelos de fevereiro, julho e junho. A maior temperatura da água foi observada no P2 na coleta de março $\left(24^{\circ} \mathrm{C}\right)$ e a menor, nos três pontos de coleta do mês de junho $\left(13^{\circ} \mathrm{C}\right)$.

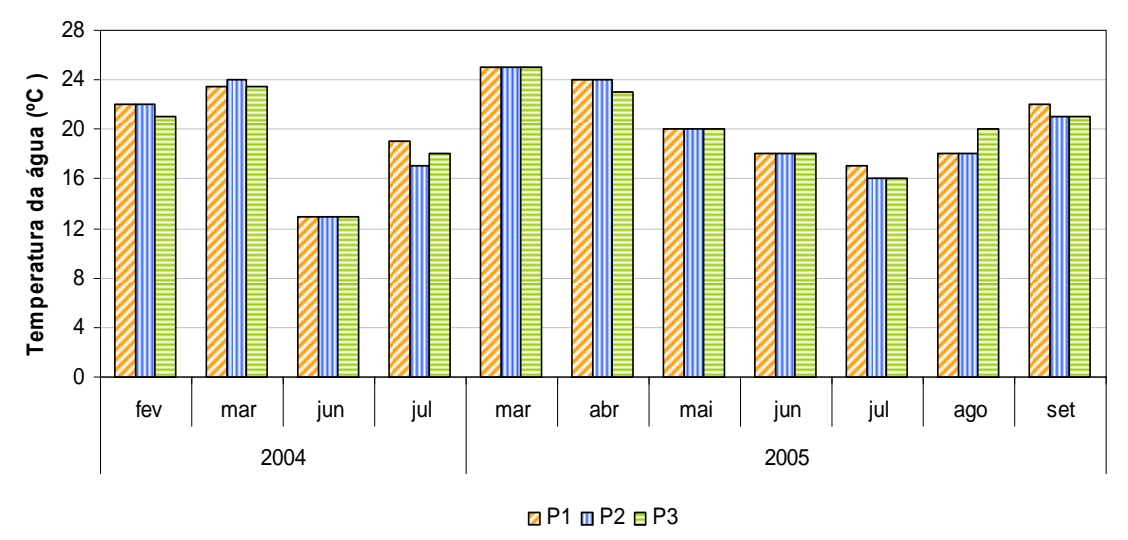

Figura 21: Variação dos valores de temperatura da água durante o período de coleta de 2004 e 2005 nas etapas do sistema de alagados construídos. 
As temperaturas mais altas encontradas na água no período de coleta de 2005 foram obtidas no mês de março $\left(25^{\circ} \mathrm{C}\right.$ em todos os pontos), seguidas pelas de abril, setembro e maio. Os valores de temperatura mais baixos do efluente foram encontrados no mês de julho e junho. No ponto 2 e 3 de julho a temperatura medida foi de $16^{\circ} \mathrm{C}$, menor valor de 2005 .

Os resultados obtidos com a análise estatística SAS e Teste de Tukey podem ser observados na tabela 9. Letras distintas indicam diferenças significativas pelo Teste de Tukey a $5 \%(\mathrm{p} \leq 0,05)$.

Tabela 9: Resultado do Teste de Tukey para a variável temperatura da água

\begin{tabular}{ccc}
\hline \multirow{2}{*}{ Pontos } & \multicolumn{2}{c}{ Média $\left({ }^{\mathbf{0}} \mathbf{C}\right)$} \\
& $\mathbf{2 0 0 4}$ & $\mathbf{2 0 0 5}$ \\
\hline 1 & $19,4 \mathrm{a}$ & $20,6 \mathrm{X}$ \\
2 & $19,0 \mathrm{a}$ & $20,3 \mathrm{X}$ \\
3 & $18,9 \mathrm{a}$ & $20,5 \mathrm{X}$ \\
\hline
\end{tabular}

Com relação ao comportamento da temperatura da água ao longo do sistema, não foi observada nenhuma diferença significativa entre os pontos de coleta nos dois anos de estudo.

Segundo Kadlec (1998), em sistemas de fluxo superficial e subsuperficial, o aquecimento solar é rapidamente dissipado pelo resfriamento através da evapotranspiração. Os processos de transformações microbiológicos, por sua vez são tipicamente dependentes da temperatura da água (KADLEC \& KNIGHT, 1996), no entanto, como era de se esperar para as regiões localizadas nos trópicos, as temperaturas máximas e mínimas encontradas no sistema não forma limitantes a decomposição da matéria orgânica nem aos processos de ciclagem do nitrogênio e fósforo (CARDOSO ${ }^{16}$ et al., 1992 apud NOGUEIRA, 2003). A temperatura, juntamente com os valores de $\mathrm{pH}$ só foram limitantes aos processos de volatilização da amônia.

\subsubsection{Oxigênio Dissolvido}

Os valores da concentração de oxigênio dissolvido em cada um dos pontos de coleta durante o período de estudo de 2004 estão representados na figura 22.

\footnotetext{
${ }^{16}$ CARDOSO, E.J.B.N.; TSAI, S.M.; NEVES, M.C.P. Microbiologia do solo. Campinas: Sociedade Brasileira de Ciência do Solo, 1992. 360p.
} 
Observou-se que a medida que as águas afluentes passavam pelos canais, a concentração de oxigênio aumentava, sendo o seu maior acréscimo na coleta do mês de junho $\left(0,97 \mathrm{mg} \cdot \mathrm{L}^{-1}\right.$ para $\left.4,14 \mathrm{mg} \cdot \mathrm{L}^{-1}\right)$.

Com relação aos solos filtrantes, após a passagem pelos módulos, a concentração de OD manteve-se alta $\left(6,75 \mathrm{mg} . \mathrm{L}^{-1}\right)$ somente no mês de fevereiro. A partir do mês de março foi observada uma queda brusca dos valores. Nas coletas realizadas neste mês e nos meses de março e julho, não foi detectada a presença de oxigênio dissolvido na água e no mês de junho, o valor encontrado foi muito baixo $\left(0,49 \mathrm{mg} \cdot \mathrm{L}^{-1}\right)$.

A concentração de oxigênio dissolvido na entrada do sistema (P1) variou entre 1,0mg. $\mathrm{L}^{-1}$ (jun) e $7,7 \mathrm{mg} . \mathrm{L}^{-1}$ (jul); no ponto 2 , de $4,1 \mathrm{mg} . \mathrm{L}^{-1}$ (jun) e $7,9 \mathrm{mg} . \mathrm{L}^{-1}$ (jul) e , na saída dos alagados (P3), de 0,5mg.L $\mathrm{L}^{-1}$ (jun) e $6,8 \mathrm{mg} \cdot \mathrm{L}^{-1}$ (fev).

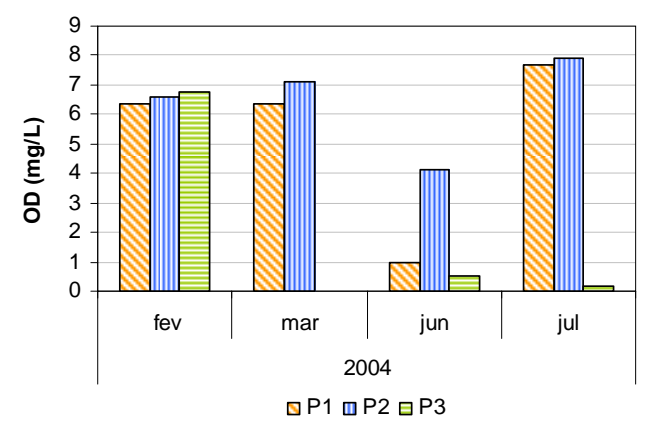

Figura 22: Variação dos valores do oxigênio dissolvido da água durante o período de coleta de 2004 nas etapas do sistema de alagados construídos.

Os resultados obtidos com a análise estatística SAS e Teste de Tukey podem ser observados na tabela 10. Letras distintas indicam diferenças significativas pelo Teste de Tukey a $5 \%(\mathrm{p} \leq 0,05)$.

Tabela 10: Resultado do Teste de Tukey para a variável oxigênio dissolvido

\begin{tabular}{cc}
\hline Pontos & $\begin{array}{c}\text { Média (mg.L } \\
\mathbf{2}\end{array}$ \\
& $\mathbf{2 0 0 4}$ \\
\hline 1 & $5,4 \mathrm{a}$ \\
2 & $6,5 \mathrm{a}$ \\
3 & $1,8 \mathrm{a}$ \\
\hline
\end{tabular}

Ao se comparar os valores médios não foi observada diferença significativa entre os pontos, apesar da redução da concentração de oxigênio dissolvido após a passagem pelos solos filtrantes, $\mathrm{O}$ fato de não ter havido diferença significativa entre P1 e P2 em relação ao $\mathrm{P} 3$, deve estar relacionado à alta concentração de oxigênio dissolvido verificada no mês de fevereiro neste último ponto, que proporcionou um aumento no valor médio encontrado. 
O aumento da concentração de oxigênio, após a passagem pelos canais, provavelmente ocorreu devido produção pelas algas (fotossíntese) e à maior difusão de oxigênio para a coluna d’água pela interface ar/água, uma vez que neste período as macrófitas estavam sendo testadas e ainda não tinham ocupado totalmente o canal. Durante o ano de 2004, o oxigênio produzido e o que entrou por difusão superaram o consumo de oxigênio pela respiração, decomposição da matéria orgânica do efluente e das plantas que não se adaptaram ao sistema (aguapé e alface d’água), nitrificação e oxidação de íons metálicos.

Nos módulos de solos filtrantes, a partir do mês de março foi observada uma queda brusca da concentração de oxigênio dissolvido. Essa redução pode estar relacionada à decomposição da matéria orgânica, respiração dos organismos aquáticos, dentre outros fatores já citados, mas principalmente ao mau funcionamento dos solos filtrantes, que teoricamente deveriam proporcionar uma maior oxigenação do efluente.

A redução da concentração de oxigênio dissolvido após a passagem pelos solos filtrantes também foi observada por Elias (2003) na estação de tratamento de água de Analândia, por Nogueira (2003) na estação para tratamento de esgoto em Piracicaba, e por Salati e colaboradores (1999) na estação piloto para pré-tratamento das águas do Rio Cotia.

Segundo Kadlec (1997), essa concentração de oxigênio diminui na maioria dos solos inundados por causa do metabolismo e oxidação química de substâncias reduzidas.

No entanto, de acordo com Nogueira (2003), o fato de um sistema de áreas alagadas construídas produzir um efluente com baixa concentração de oxigênio dissolvido pode ser corrigido com a implantação de estratégias simples em sua saída, como por exemplo, cascatas e corredeiras.

Para as coletas dos meses de fevereiro, março e julho de 2004, as concentrações de oxigênio dissolvido medidas nos pontos de entrada do sistema e saída do canal de macrófitas atendem a Resolução CONAMA 357/2005 (BRASIL, 2005) apresentando valores acima de $5 \mathrm{mg} . \mathrm{L}^{-1}$. No entanto, todos os valores encontrados na saída do sistema (exceto a coleta de fevereiro) ficaram abaixo do limite estabelecido pela legislação para águas doces de classe 2 . Na coleta do mês de junho, a concentração medida no ponto de entrada do sistema já apresentava um valor abaixo do permitido provavelmente devido a um aumento da taxa de decomposição aeróbia ou da taxa de nitrificação no lago. A 
maior concentração de nitrato observada durante o período de estudo em 2004 ocorreu neste mês.

\subsubsection{Potencial Hidrogeniônico}

Os valores do $\mathrm{pH}$ da água em cada um dos pontos de coleta durante o período de estudo estão representados na figura 23.

$\mathrm{O}$ pH na entrada dos alagados construídos (P1) em 2004 variou entre 7,1 (fev) e 7,6 (mar); no ponto 2 entre 6,9 (fev) e 7,3 (mar) e, na saída do sistema, (P3) entre 6,4 (mar) e 7,0 (fev).

Com relação ao período de 2005, os valores de P1 variaram entre 7,3 (jul) e 7,7 (mai/set); no ponto 2, entre 6,7 (abr/jun/jul) e 7,0 (ago/set) e, na saída do sistema, de $6,1($ jun) a 6,7 (set).

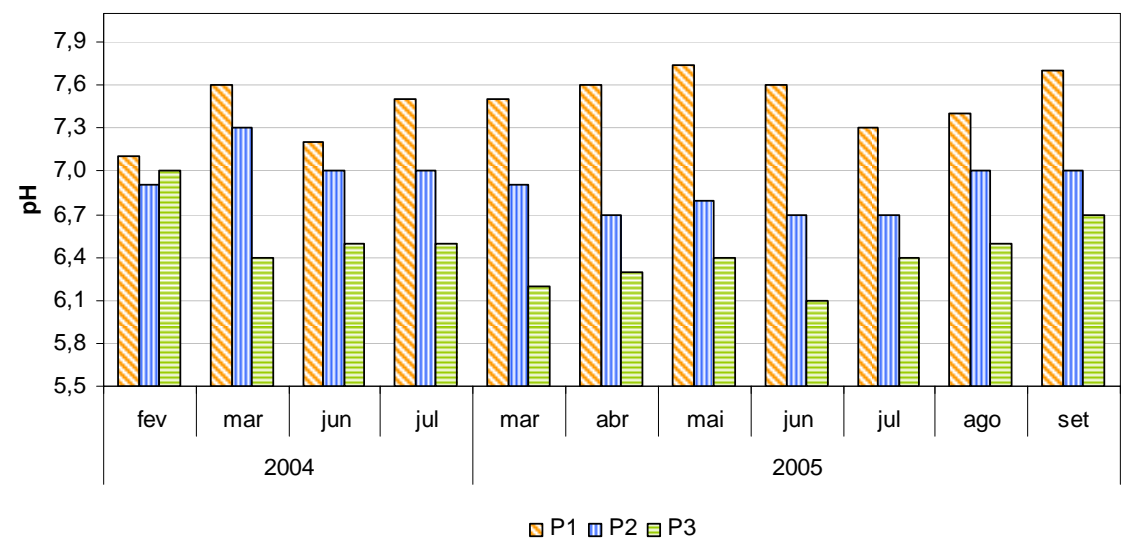

Figura 23: Variação dos valores do pH da água durante o período de coleta de 2004 e 2005 nas etapas do sistema de alagados construídos.

Os resultados obtidos com a análise estatística SAS e Teste de Tukey podem ser observados na tabela 11. Letras distintas indicam diferenças significativas pelo Teste de Tukey a $5 \%(\mathrm{p} \leq 0,05)$.

Tabela 11: Resultado do Teste de Tukey para a variável $\mathrm{pH}$

\begin{tabular}{ccc}
\hline \multirow{2}{*}{ Pontos } & \multicolumn{2}{c}{ Média } \\
& $\mathbf{2 0 0 4}$ & $\mathbf{2 0 0 5}$ \\
\hline 1 & $7,4 \mathrm{a}$ & $7,6 \mathrm{X}$ \\
2 & $7,1 \mathrm{ab}$ & $6,8 \mathrm{Y}$ \\
3 & $6,6 \mathrm{~b}$ & $6,4 \mathrm{Z}$ \\
\hline
\end{tabular}


Ao se analisar as flutuações do $\mathrm{pH}$ durante o período de estudo, verificou-se que, apesar do efluente bruto ser caracteristicamente mais básico, ao atravessar as etapas do sistema, tornou-se mais ácido. Em 2004, ao se comparar as médias dos valores de pH entre os pontos, pode-se afirmar, com um nível de significância de 5\%, que P1 é difere significativamente de $\mathrm{P} 3$, mas não de $\mathrm{P} 2$, e P2 não é significativamente diferente de $\mathrm{P} 3$. A maior média de pH encontrada foi no P1 $(7,4)$ e a menor no P3 $(6,6)$.

Já para o ano de 2005, os valores encontrados no P1, P2 e P3 foram significativamente diferentes um do outro, sendo o maior $(7,6)$ encontrado no ponto 1 , efluente de entrada, e o menor $(6,4)$ valor no ponto 3 , efluente de saída do sistema.

Essa ligeira acidificação da água deve-se ao fato de que as substâncias geradas dentro de uma área alagada por crescimento (liberação de substâncias orgânicas metabólitos), morte e decomposição são fontes naturais de acidificação (KADLEC \& KNIGHT, 1996).

Segundo Watson e colaboradores (1989), vários processos metabólicos que ocorrem nas águas podem gerar íons hidrogênio e abaixar o pH do meio. Entre estes se destacam: os processos de oxidação biológica e fermentação, trocas catiônicas e o processo de hidrólise de cátions. Outras fontes de íons são os ácidos orgânicos e inorgânicos formados, que no meio aquoso, se dissociam em $\mathrm{H}^{+}$e ânions.

Essa acidificação do efluente após a passagem pelo sistema de alagados construídos também foi observada no tratamento de águas residuárias de escoamento rural (NEWMAN, CLAUSEN \& NEAFSEY, 2000), de esgoto doméstico (NOGUEIRA, 2003), de destilarias (BILLORE et al., 2000), e no tratamento de água para abastecimento público (ELIAS, 2003).

Durante todo o período de estudo de 2004 e 2005, os valores encontrados em todos os pontos de coleta atendem a resolução CONAMA 357/2005 para águas doces de classe 2 (BRASIL, 2005), apresentando valores de $\mathrm{pH}$ entre 6 e 9.

Para os parâmetros discutidos a seguir serão mostrados os resultados da concentração das variáveis em cada uma das etapas do sistema, além da eficiência de remoção parcial e total do sistema combinado de alagados construídos. Os valores de remoção citados para a primeira etapa do sistema - canal - correspondem à eficiência do conjunto: canal de decantação e canal de macrófitas. 


\subsubsection{Alcalinidade}

A alcalinidade é um fator importante, pois mede a quantidade de íons na água que reagirão para neutralizar os íons de hidrogênio (capacidade de tamponamento). Os principais constituintes da alcalinidade são os bicarbonatos, carbonatos e hidróxidos, e a distribuição entre estas três formas ocorre em função do $\mathrm{pH}$. No período de estudo, como os valores de $\mathrm{pH}$ encontrados ficaram na faixa de 4,4 e 8,3, segundo Von Sperling (1996), a maior composição era de bicarbonatos.

Os valores da alcalinidade da água obtidos nos pontos de coleta em 2004 estão representados na figura 24 .

A alcalinidade medida na entrada do sistema (P1) variou entre $36,3 \mathrm{mgCaCO} / \mathrm{L}$ (fev) e $54,5 \mathrm{mgCaCO}_{3} / \mathrm{L}$ (jun), na faixa de $25,7 \mathrm{mgCaCO}_{3} / \mathrm{L}$ (fev) a 49,2 $\mathrm{mgCaCO}_{3} / \mathrm{L}$ (jul) no ponto 2 , e na saída do sistema (P3), os valores ficaram entre $25,9 \mathrm{mgCaCO}_{3} / \mathrm{L}$ (fev) e 50,8 $\mathrm{mgCaCO}_{3} / \mathrm{L}$ (jul).

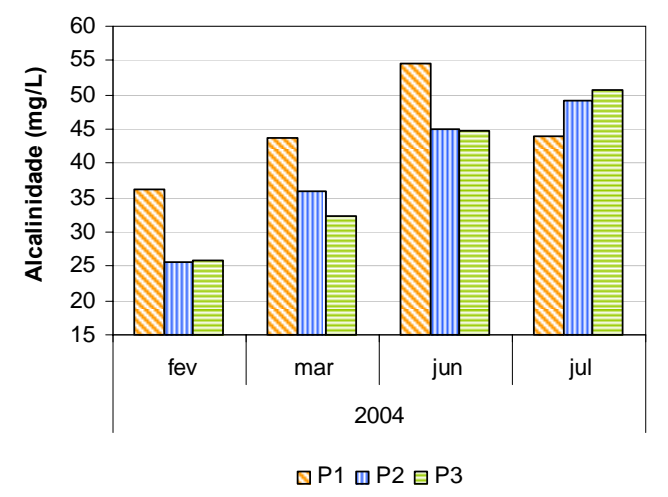

Figura 24: Variação dos valores de alcalinidade da água durante o período de coleta de 2004 nas etapas do sistema de alagados construídos.

Os resultados obtidos com a análise estatística SAS e Teste de Tukey podem ser observados na tabela 12. Letras distintas indicam diferenças significativas pelo Teste de Tukey a $5 \%(\mathrm{p} \leq 0,05)$.

Tabela 12: Resultado do Teste de Tukey para a variável alcalinidade.

\begin{tabular}{cc}
\hline Pontos & $\begin{array}{c}\text { Média (mg. } \mathbf{L}^{\mathbf{1}} \text { ) } \\
\text { 2004 }\end{array}$ \\
\hline 1 & $44,6 \mathrm{a}$ \\
2 & $39,0 \mathrm{a}$ \\
3 & $38,5 \mathrm{a}$ \\
\hline
\end{tabular}

Observou-se que na maioria dos meses de coleta, a alcalinidade total medida na entrada do sistema de alagados (P1) apresentou valores mais altos do que o ponto de 
saída (P3). Este fato só não foi evidenciado no mês de julho em que houve um aumento após a passagem pelo alagado construído, fato que contribuiu com o aumento da concentração média no P2 e P3, possivelmente sendo responsável para que não houvesse diferença significativa entre o P1 e os demais pontos.

As eficiências de remoção parcial e total da alcalinidade da água, durante o período de estudo em 2004, podem ser visualizadas na figura 25.

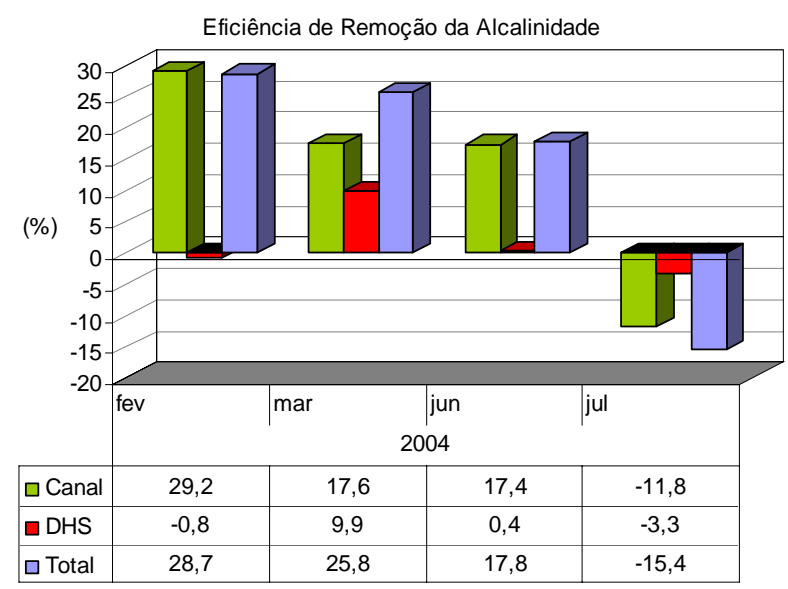

Figura 25: Eficiência total e de cada uma das etapas do sistema de alagados construídos na remoção da alcalinidade durante o período de coleta de 2004.

Após a passagem pelos canais de decantação e de macrófitas observou-se uma redução da alcalinidade da água na maioria dos meses de coleta, exceto no mês de julho em que a concentração aumentou cerca de $12 \%$ do valor de entrada do sistema. A eficiência de remoção para esta etapa variou entre 17,4\% (jun) e 29,2\% (fev).

Com relação aos solos filtrantes, somente a coleta do mês de março apresentou uma boa eficiência de remoção $(9,9 \%)$. Nos meses de fevereiro e junho não foi observada uma redução da alcalinidade e no mês de julho a concentração aumentou cerca de $3,3 \%$.

A maior eficiência de remoção total do sistema foi observada no mês de fevereiro $(28,7 \%)$ seguido pelo mês de março $(25,8 \%)$ e junho $(17,8 \%)$. No mês de julho verificou-se um aumento da alcalinidade em todas as etapas do sistema, e por isso obteve-se uma eficiência de remoção negativa, ou seja, um acréscimo de 15,4\% no valor medido na entrada do alagado construído.

A redução dos valores de alcalinidade provavelmente está relacionada com as reações de neutralização dos íons de hidrogênio liberados pelos processos de 
crescimento e pela decomposição das macrófitas (fontes de acidificação naturais), como já citado anteriormente. A alcalinidade é consumida também no processo de nitrificação da amônia (Watson et al., 1989). Segundo estes mesmos autores, como produção de alcalinidade pode-se citar os processos de redução do sulfato e do nitrato.

A taxa de remoção média em 2004 foi de 14,2\%. São poucos os trabalhos de alagados construídos que abordam o comportamento da variável alcalinidade no sistema. Como exemplo, pode-se citar o trabalho desenvolvido por Jucá (2003) em Pernambuco. O autor, ao pesquisar a utilização de alagados construídos para tratamento de chorume proveniente do Aterro de Muribeca, observou uma taxa de remoção de $23,1 \%$ após a passagem por um canal de macrófitas emergentes.

\subsubsection{Dureza}

A dureza da água é medida pela concentração de íons multimetálicos em solução. Os cátions mais freqüentemente associados à dureza são os bivalentes $\mathrm{Ca}^{2+} \mathrm{e}$ $\mathrm{Mg}^{2+}$ (VON SPERLING, 1996).

Os valores da dureza da água obtidos nos pontos de coleta em 2004 estão representados na figura 26.

A dureza medida na entrada do sistema (P1) variou de $34,1 \mathrm{mgCaCO}_{3} / \mathrm{L}$ (fev) a $46,7 \mathrm{mgCaCO}_{3} / \mathrm{L}$ (jun), no ponto de 2 de $28,2 \mathrm{mgCaCO}_{3} / \mathrm{L}$ (fev) a $39,9 \mathrm{mgCaCO}_{3} / \mathrm{L}$ (jul), e na saída do sistema (P3), os valores ficaram na faixa de $24,6 \mathrm{mgCaCO}_{3} / \mathrm{L}$ (fev) a $37 \mathrm{mgCaCO}_{3} / \mathrm{L}$ (jul).

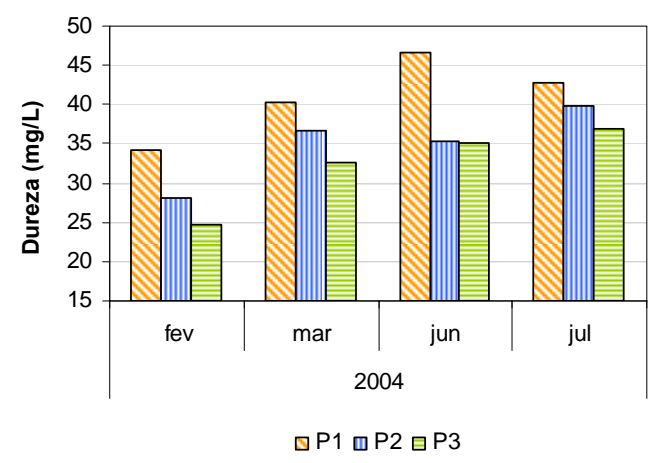

Figura 26: Variação dos valores da dureza da água durante o período de coleta de 2004 nas etapas do sistema de alagados construídos.

Os resultados obtidos com a análise estatística SAS e Teste de Tukey podem ser observados na tabela 13. Letras distintas indicam diferenças significativas pelo Teste de Tukey a $5 \%(\mathrm{p} \leq 0,05)$. 
Tabela 13: Resultado do Teste de Tukey para a variável dureza.

\begin{tabular}{cc}
\hline Pontos & $\begin{array}{c}\text { Média (mg.L } \mathbf{L}^{-1} \text { ) } \\
\mathbf{2 0 0 4}\end{array}$ \\
\hline 1 & $40,9 \mathrm{a}$ \\
2 & $35,0 \mathrm{ab}$ \\
3 & $32,3 \mathrm{~b}$ \\
\hline
\end{tabular}

Observou-se que em todos os meses de coleta, a dureza total medida na entrada do sistema de alagados (P1) apresentou os maiores valores enquanto que o ponto de saída do sistema (P3), os menores. No entanto, ao se comparar os valores médios encontrados em cada um dos pontos de coleta durante o período de 2004, pode-se afirmar que P1 é significativamente diferente de P3, mas não de P2. O valor médio encontrado em P2 não é significativamente diferente do P3. Ou seja, após a passagem pelo sistema de alagados construídos, houve uma redução significativa da dureza da água.

As eficiências de remoção parcial e a total da dureza da água, durante o período de estudo em 2004, podem ser visualizadas na figura 27.

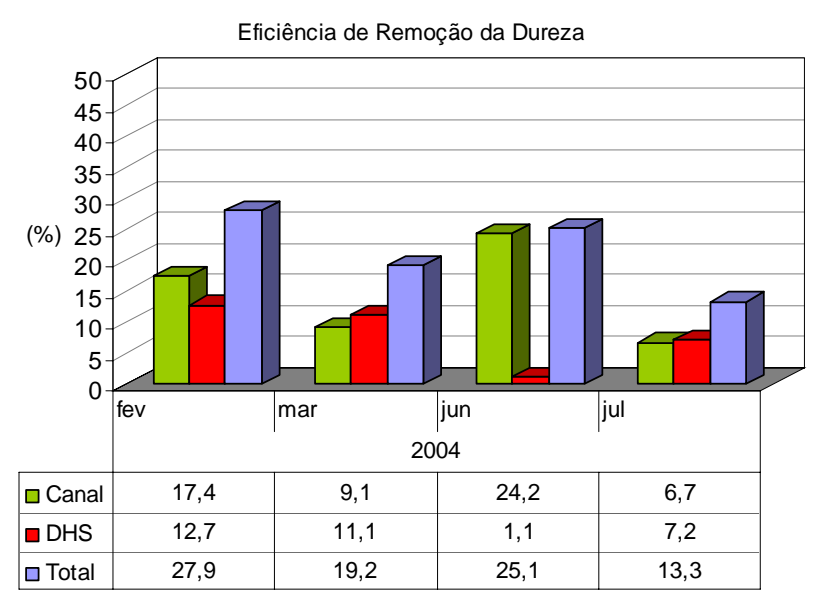

Figura 27: Eficiência total e de cada uma das etapas do sistema de alagados construídos na remoção da dureza durante o período de coleta de 2004.

Após a passagem pelo canal de decantação e de macrófitas aquáticas houve uma redução da dureza da água em todos os meses de coleta. A eficiência de remoção para esta etapa variou entre $6,7 \%$ (jul) e $24,2 \%$ (fev).

Com relação aos solos filtrantes, somente a coleta do mês de junho apresentou uma baixa eficiência de remoção $(1,1 \%)$. Nos outros meses a taxa de remoção variou entre $7,2 \%$ (jul) e 12,7 (fev). 
A eficiência de remoção total do sistema combinado de alagados construídos variou de 13,3 (jul) a 27,9\% (fev).

Essa redução provavelmente ocorreu devido à assimilação dos íons, principalmente cálcio e magnésio, pela microbiota e pelas macrófitas, uma vez que estes íons têm um importante papel na produtividade global (ESTEVES, 1988), além das reações de troca catiônica (KADLEC at al., 2000).

O cálcio é essencial para o crescimento das algas, macrófitas e muitos animais (manutenção da membrana celular). Ele pode ser encontrado na água em duas formas principais: carbonato e bicarbonato de cálcio. Nestas formas (alcalinidade) há, portanto, uma interferência no pH (efeito tampão) e também nos processos de nitrificação da amônia. O consumo dos carbonatos e bicarbonatos nos processos citados anteriormente e a neutralização dos íons de hidrogênio podem estar relacionados à remoção da dureza no sistema (ESTEVES, 1988; WATSON et al. 1989).

Com relação ao magnésio, sua importância está na formação da molécula de clorofila e na participação de processos metabólicos - metabolismo do nitrogênio, dentre outros (ESTEVES, 1988).

O aumento da dureza no sistema em julho no canal de macrófitas pode estar relacionado com a morte e decomposição das plantas aquáticas, principalmente do aguapé e do alface d’água. Com a decomposição destas plantas haveria, portanto, uma liberação dos íons para a coluna d’água.

Nos solos filtrantes, o aumento da dureza, assim como o aumento da alcalinidade, pode estar relacionado com os processos de redução do sulfato e com a decomposição da matéria orgânica.

A taxa de eficiência total média do sistema em 2004 foi de 21,4\%. Não há na literatura dados sobre a dureza em alagados construídos, somente alguns trabalhos medindo a quantidade de íons presentes em cada etapa do sistema.

Kadlec e colaboradores (2000) obtiveram eficiências de remoção de 39\% para cálcio, 4\% para potássio e um acréscimo de $23 \%$ na concentração de sódio de um efluente de escoamento urbano após a passagem por um sistema de alagados composto por dois canais de macrófitas.

\subsubsection{Cloretos}

A variação dos valores de cloretos da água em cada um dos pontos de coleta em 2004 e 2005 está representada na Figura 28. 
Os valores medidos em 2004 na entrada do sistema (P1) variaram entre $24,5 \mathrm{mgCl} . \mathrm{L}^{-1}$ (mar) e $29 \mathrm{mgCl} / \mathrm{L}$ (jun), no $\mathrm{P} 2$ variaram entre $18,8 \mathrm{mgCl} . \mathrm{L}^{-1}$ (fev) e $28,5 \mathrm{mgCl} \cdot \mathrm{L}^{-1}$ (jul) e na saída do sistema (P3), os valores ficaram na faixa de $18,7 \mathrm{mgCl} \cdot \mathrm{L}^{-1}$ (fev) à $28,4 \mathrm{mgCl} \cdot \mathrm{L}^{-1}$ (jul).

No ano de 2005, os valores em P1 variaram entre 24,6mgCl. $\mathrm{L}^{-1}$ (jul) e $29,3 \mathrm{mgCl} . \mathrm{L}^{-1}$ (mai), no P2 variaram entre $21 \mathrm{mgCl} . \mathrm{L}^{-1}$ (mar) e $28,7 \mathrm{mgCl} . \mathrm{L}^{-1}$ (mai) e no $\mathrm{P} 3$, os valores ficaram na faixa de $17,3 \mathrm{mgCl} \cdot \mathrm{L}^{-1}$ (jun) à $29 \mathrm{mgCl} . \mathrm{L}^{-1}$ (mai).

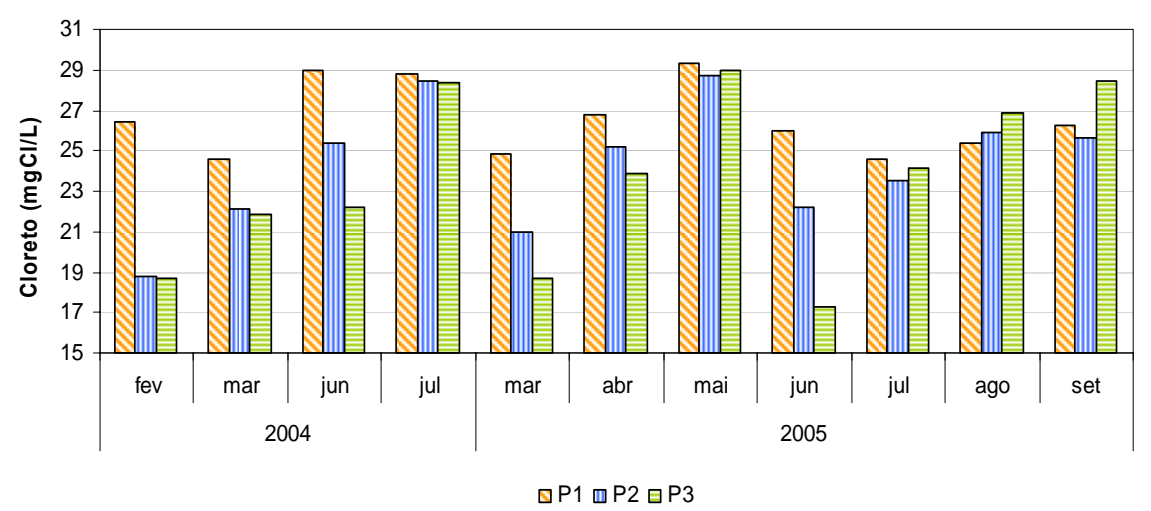

Figura 28: Variação dos valores de cloretos da água durante o período de coleta de 2004 e 2005 nas etapas do sistema de alagados construídos.

Os resultados obtidos com a análise estatística SAS e Teste de Tukey podem ser observados na tabela 14. Letras distintas indicam diferenças significativas pelo Teste de Tukey a $5 \%(\mathrm{p} \leq 0,05)$.

Tabela 14: Resultado do Teste de Tukey para a variável cloretos.

\begin{tabular}{ccc}
\hline \multirow{2}{*}{ Pontos } & \multicolumn{2}{c}{ Média (mg. - $^{\mathbf{1}}$ ) } \\
& $\mathbf{2 0 0 4}$ & $\mathbf{2 0 0 5}$ \\
\hline 1 & $27,2 \mathrm{a}$ & $26,2 \mathrm{X}$ \\
2 & $23,7 \mathrm{a}$ & $24,6 \mathrm{X}$ \\
3 & $22,8 \mathrm{a}$ & $24,1 \mathrm{X}$ \\
\hline
\end{tabular}

A maior concentração média de cloretos, durante os dois períodos de estudos, foi encontrada na entrada do sistema (P1) e a menor no ponto de saída (P3). No entanto, com um nível de significância de 5\%, pode-se afirmar que não há diferença significativa entre os pontos de coleta.

As eficiências de remoção parcial de cloretos da água, durante o período de estudo em 2004 e 2005, podem ser visualizadas na figura 29. 


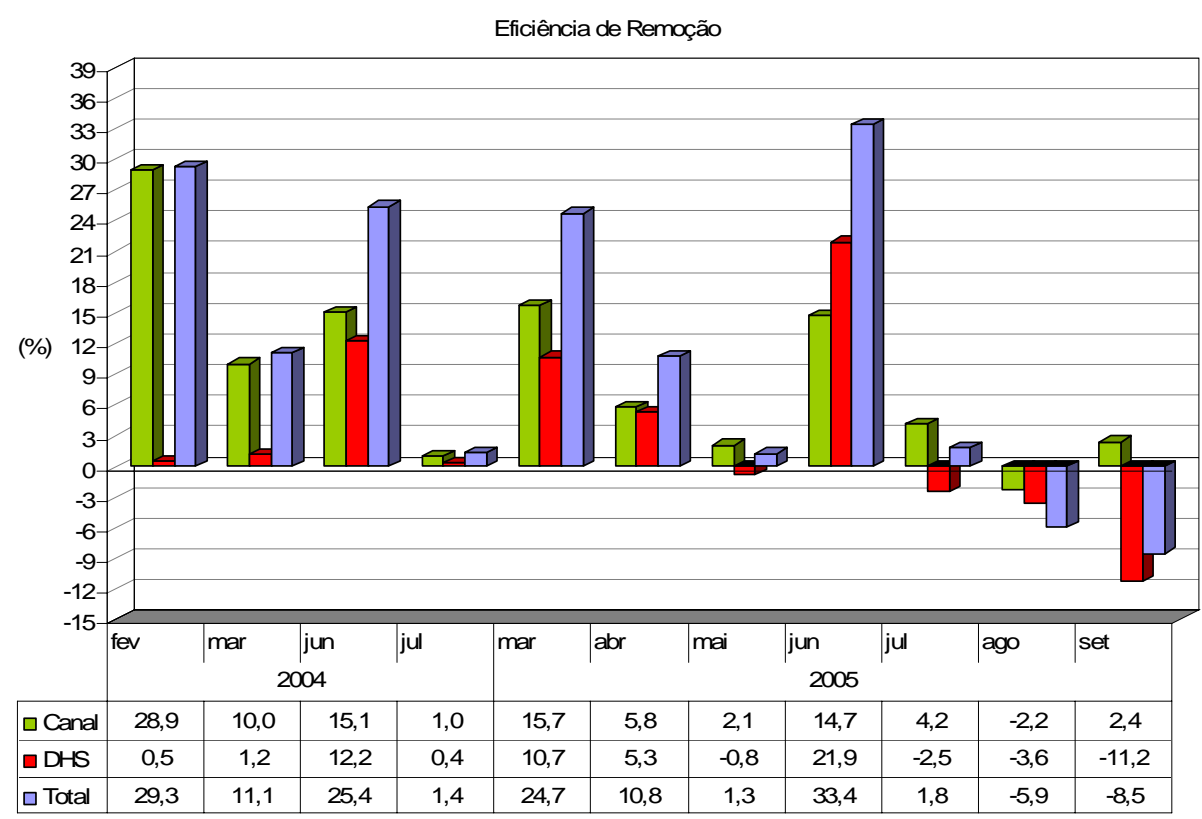

Figura 29: Eficiência total e de cada uma das etapas do sistema de alagados construídos na remoção de cloretos durante o período de coleta de 2004 e 2005.

Após a passagem pelo canal de decantação e de macrófitas aquáticas houve uma redução da concentração de cloretos na água em todos os meses de coleta, exceto na coleta de agosto de 2005 (-2,2\%). A eficiência de remoção variou entre 1,0\% (jul/04) e $28,9 \%(\mathrm{fev} / 04)$.

Com relação aos solos filtrantes no ano de 2004, os meses de coleta apresentaram, em sua maioria, uma baixa eficiência de remoção (menor que 1,2\%), exceto mês de junho em que se verificou uma taxa de remoção de 12,2\%.

Em 2005 foi observado um desempenho de remoção positivo dos solos somente nos meses março, abril e junho, com uma taxa que variou de 5,3\% (abr) e 21,9\% (jun). Para os outros meses a eficiência foi negativa, com um acréscimo que variou entre $0,8 \%$ (mai) e $11,2 \%$ (set).

Após a passagem pelo sistema combinado de alagados construídos, observou-se uma redução da concentração de cloretos da água na maioria do período de estudo, co exceção para a coleta do mês de agosto $(-5,9 \%)$ e setembro $(-8,5 \%)$ de 2005 . A eficiência de remoção total do sistema variou de 1,3\% (mai/05) a 33,4\% (jun/05).

A remoção pode ter ocorrido provavelmente pela absorção dos íons pela microbiota e macrófitas, e também pela formação de complexos com os íons metálicos (LEITÃO et al., 2006). 
O aumento da concentração de íons cloretos provavelmente ocorreu devido à morte e decomposição das macrófitas, com o retorno dos cloretos assimilados.

A taxa de remoção total média foi de 16,8\% em 2004 e de 8,2\% em 2005. Poucos são os trabalhos que analisam esta variável. Dentre eles, pode-se citar o trabalho desenvolvido por Salati e colaboradores (1999) que observaram um aumento de $27 \%$ na concentração de cloretos das águas do Rio Cotia após a passagem pelo sistema de alagados. Um outro estudo envolvendo o tratamento de águas de escoamento urbano também apresentou um acréscimo de cloretos de 189\% após o sistema de alagados construídos (KADLEC et al., 2000).

Campos (2000) e Cecconelo (2005), ao tratarem percolados de aterro sanitário utilizando um sistema de alagados construídos com macrófitas emergentes, verificou uma remoção de cloretos que variou de 50 a $80 \%$ e de 14,1 a $68,7 \%$ respectivamente.

Durante todo o período de estudo de 2004 e 2005, a concentração de cloretos medida em todos os pontos de coleta atende a Resolução CONAMA 357/2005 (BRASIL, 2005) para águas doces de classe 2, apresentando valores bem abaixo do limite estipulado de $250 \mathrm{mg} . \mathrm{L}^{-1}$.

\subsubsection{Sulfato}

Os valores da concentração de sulfato da água obtidos nos pontos de coleta em 2004 estão representados na figura 30 .

Observa-se que em todos os meses de coleta, a concentração de sulfato medida na entrada do sistema de alagados (P1) apresentou valores mais altos do que o ponto de saída (P3).

A concentração medida em 2004 na entrada do alagado (P1) variou entre 11,4mg. $\mathrm{L}^{-1}$ (jul) e $13 \mathrm{mg} . \mathrm{L}^{-1}$ (mar); no ponto 2, entre $9,6 \mathrm{mg} \cdot \mathrm{L}^{-1}$ (jun) e $12 \mathrm{mg} \cdot \mathrm{L}^{-1}$ (mar) e, na saída do sistema (P3), entre 2,5mg.L $\mathrm{L}^{-1}$ (jul) e 9,7mg.L $\mathrm{L}^{-1}$ (fev).

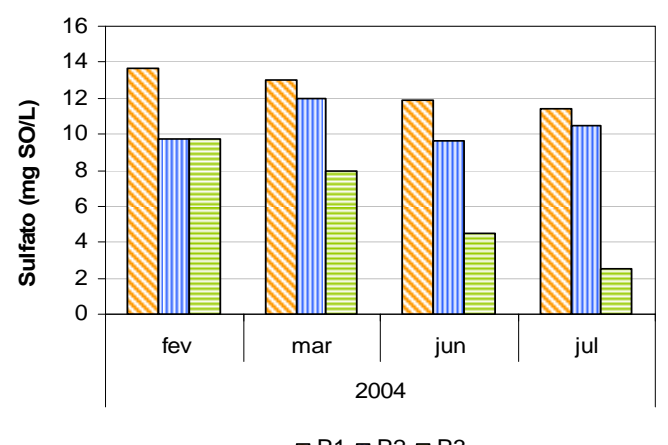

Figura 30: Variação dos valores de sulfato da água durante o período de coleta de 2004 nas etapas do sistema de alagados construídos. 
Os resultados obtidos com a análise estatística SAS e Teste de Tukey podem ser observados na tabela 15. Letras distintas indicam diferenças significativas pelo Teste de Tukey a $5 \%(\mathrm{p} \leq 0,05)$.

Tabela 15: Resultado do Teste de Tukey para a variável sulfato.

\begin{tabular}{cc}
\hline Pontos & $\begin{array}{c}\text { Média (mg. } \mathbf{L}^{-1} \text { ) } \\
\mathbf{2 0 0 4}\end{array}$ \\
\hline 1 & $12,5 \mathrm{a}$ \\
2 & $10,5 \mathrm{a}$ \\
3 & $6,2 \mathrm{~b}$ \\
\hline
\end{tabular}

Ao se comparar os valores médios da concentração de sulfato nos pontos de coleta em 2004, verificou-se uma remoção tanto pelos canais quanto pelos solos filtrantes, no entanto somente a última etapa apresentou uma eficiência significativa. $\mathrm{O}$ menor valor médio foi encontrado no P3 $\left(6,2 \mathrm{mg} \cdot \mathrm{L}^{-1}\right)$.

As eficiências de remoção parcial e a total de sulfato da água, durante o período de estudo em 2004, podem ser visualizadas na figura 31.

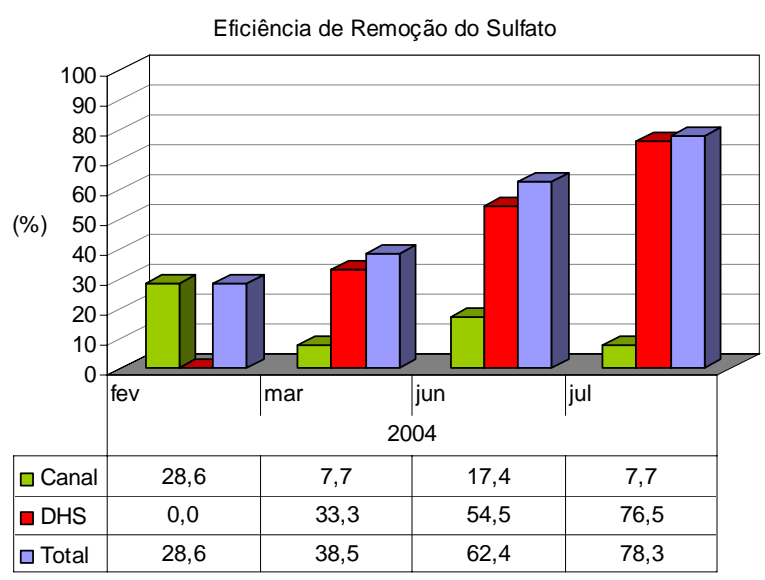

Figura 31: Eficiência total e de cada uma das etapas do sistema de alagados construídos na remoção de sulfato durante o período de coleta de 2004.

Após a passagem pelo canal de decantação e de macrófitas aquáticas houve uma redução dos valores de sulfato da água que variou entre 7,7\% (mar/jul) e 28,6\% (fev).

Com relação aos solos filtrantes, a maioria das coletas também apresentou uma remoção positiva de sulfato que variou entre 33,3\% (mar) e 76,5\% (jul). Somente a coleta do mês de fevereiro não apresentou redução da concentração da variável.

A eficiência de remoção total do sistema de alagados variou entre 28,6\% (fev) e $78,3 \%$ (jul). 
Segundo Faulkner e Richardson (1989), o íon sulfato pode ser removido no sistema por processos químicos e biológicos. O processo químico envolve a adsorção do íon sulfato nas partículas do solo (troca catiônica) e a formação de complexos com os íons metálicos (LEITÃO et al., 2006).

A redução do sulfato por processo biológico ocorre em ambientes aquáticos sob condições anaeróbias, através de bactérias heterotróficas denominadas dessulfurantes (ESTEVES, 1988). O sulfato é utilizado como aceptor final de elétrons (respiração do sulfato) e como resultado tem-se a produção de $\mathrm{H}_{2} \mathrm{~S}$ e alcalinidade (HEDIN, HAMMACK \& HYAMAN, 1989). O gás sulfídrico formado é perdido para a atmosfera ou se dissolve e ioniza para gerar íons sulfeto, que reagem com uma série de íons metálicos e precipitam (FAULKNER \& RICHARDSON, 1989).

Durante o estudo, pode-se inferir que a remoção significativa do sulfato tenha ocorrido nos solos filtrantes por causa da condição de anaerobiose.

A taxa de remoção total média do sistema em 2004 foi de 52\%. Como pôde ser observado, a eficiência de remoção aumentou ao longo dos meses de estudo, provavelmente devido ao estabelecimento das bactérias heterotróficas dessulfurantes e pela condição de anaerobiose dos solos em março, junho e julho. Como no mês de fevereiro, a concentração de oxigênio dissolvido encontrada no efluente dos solos filtrantes era alta $\left(6,8 \mathrm{mg} . \mathrm{L}^{-1}\right)$ houve limitação do processo.

Eficiências de remoção de $56 \%$ e de $77 \%$ foram obtidas em experimentos em pântanos nos Estados Unidos (FAULKER \& RICHARDSON, 1989). Jucá (2003), utilizando um canal de macrófitas emergentes para tratar percolados de aterro sanitário, verificou uma eficiência de remoção de $97,7 \%$ do sulfato.

Durante todo o período de estudo de 2004, todos os pontos de coleta apresentaram uma concentração de sulfatos abaixo do limite estipulado de $250 \mathrm{mg} . \mathrm{L}^{-1}$, atendendo a Resolução CONAMA 357/2005 (BRASIL, 2005) para águas doces de classe 2.

\subsubsection{Condutividade}

A variação dos valores de condutividade elétrica da água em cada um dos pontos de coleta em 2004 e 2005 está representada na Figura 32.

Os dados obtidos em 2004 na entrada do sistema de alagados (P1) variaram entre $184 \mu \mathrm{mho} / \mathrm{cm}$ (fev) a $229 \mu \mathrm{mho} / \mathrm{cm}$ (jul), no P2 entre $138 \mu \mathrm{mho} / \mathrm{cm}$ (fev) e $235 \mu \mathrm{mho} / \mathrm{cm}$ 
(jul), e no ponto de saída (P3) de $137 \mu \mathrm{mho} / \mathrm{cm}$ (fev) a 196,3 $\mu \mathrm{mho} / \mathrm{cm}$ (jul). Os menores valores, dentro de um mesmo mês de coleta, foram encontrados em fevereiro e os maiores, em julho.

No ano de 2005, os valores em P1 variaram entre 180,2 $\mu \mathrm{mho} / \mathrm{cm}$ (mar) e $276 \mu \mathrm{mho} / \mathrm{cm}$ (jul), no P2 entre $166,2 \mu \mathrm{mho} / \mathrm{cm}$ (jun) e $245 \mu \mathrm{mho} / \mathrm{cm}$ (jul), e no P3 de $155 \mu \mathrm{mho} / \mathrm{cm}$ (mar) a $229 \mu \mathrm{mho} / \mathrm{cm}$ (set).

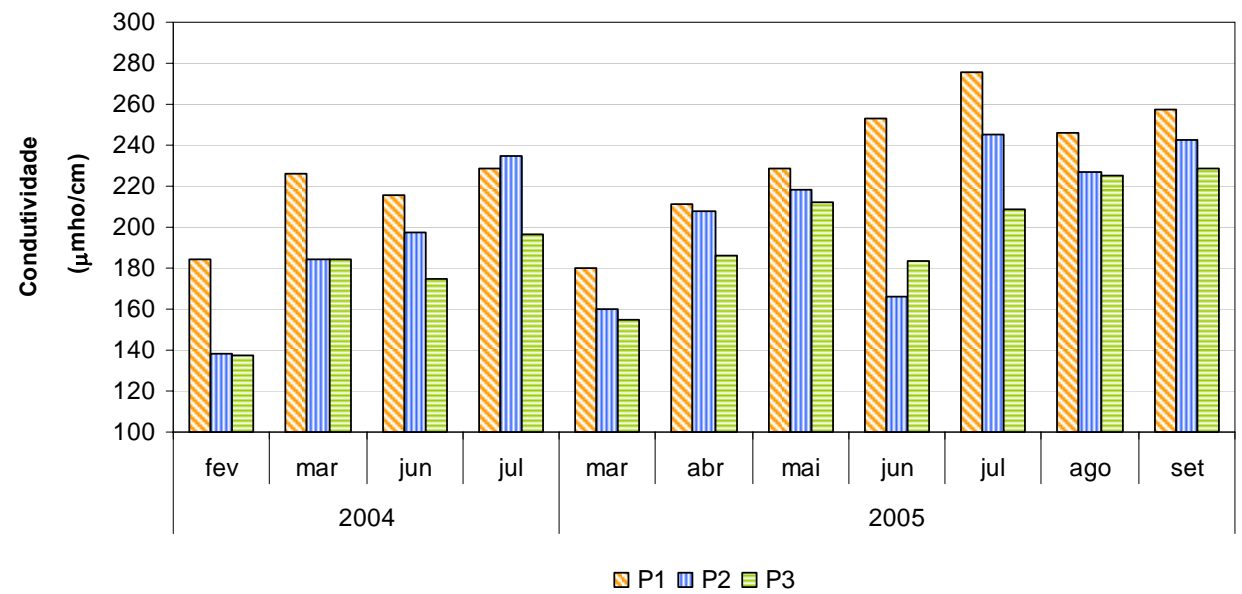

Figura 32: Variação dos valores da condutividade da água durante o período de coleta de 2004 e 2005 nas etapas do sistema de alagados construídos.

Os resultados obtidos com a análise estatística SAS e Teste de Tukey podem ser observados na tabela 16. Letras distintas indicam diferenças significativas pelo Teste de Tukey a $5 \%(\mathrm{p} \leq 0,05)$.

Tabela 16: Resultado do Teste de Tukey para a variável condutividade

\begin{tabular}{ccc}
\hline \multirow{2}{*}{ Pontos } & \multicolumn{2}{c}{ Média $(\boldsymbol{\mu m h o / c m )}$} \\
& $\mathbf{2 0 0 4}$ & $\mathbf{2 0 0 5}$ \\
\hline 1 & $213,8 \mathrm{a}$ & $236,0 \mathrm{X}$ \\
2 & $188,7 \mathrm{a}$ & $209,6 \mathrm{X}$ \\
3 & $173,1 \mathrm{a}$ & $199,9 \mathrm{X}$ \\
\hline
\end{tabular}

Ao se observar a condutividade elétrica, no ano de 2004 e 2005, foi possível verificar que, em sua maioria, os maiores valores foram encontrados nas amostras coletadas em P1 e os menores em P3 (exceto jul/04 e jun/05). No entanto, por este teste tratar os dados através da comparação dos valores médios, não foram observadas diferenças significativas entre os pontos de coleta.

As eficiências de remoção parcial e a total da condutividade da água, durante o período de estudo em 2004 e 2005, podem ser visualizadas na figura 33. 


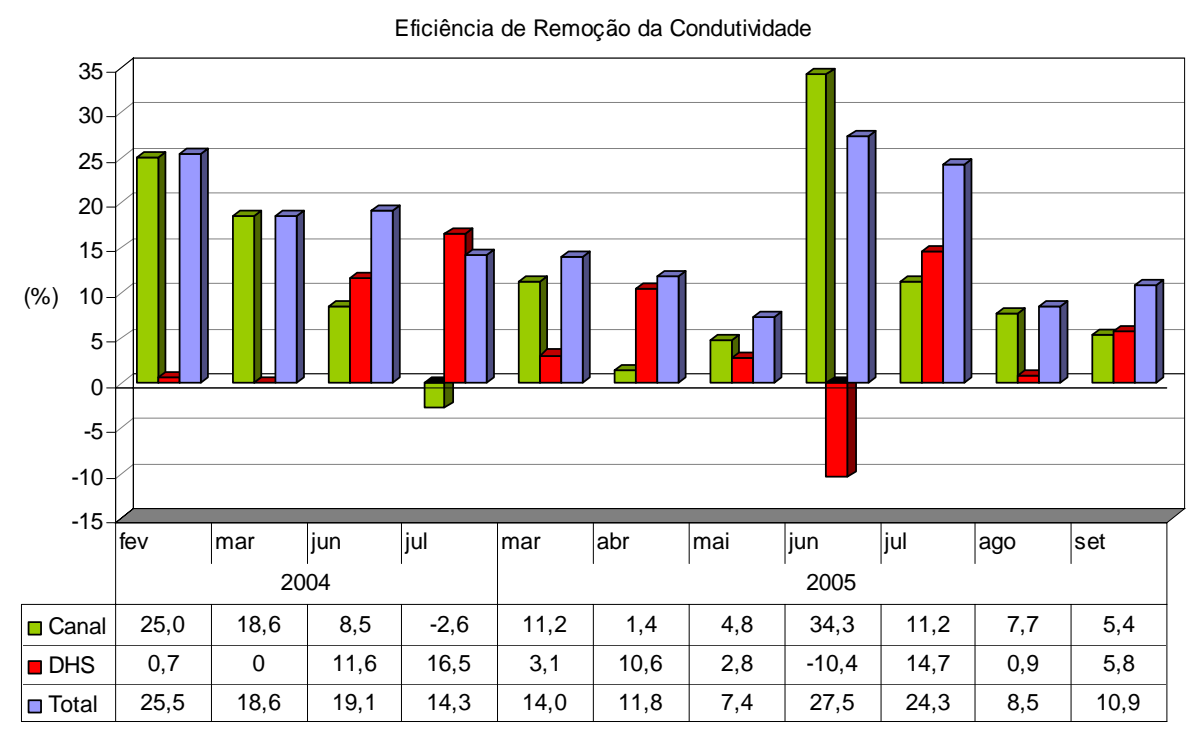

Figura 33: Eficiência total e de cada uma das etapas do sistema de alagados construídos na remoção da condutividade durante o período de coleta de 2004 e 2005.

O conjunto de canais mostrou-se eficiente na remoção da condutividade da água em todos os meses de coleta. A taxa de remoção variou na faixa de 1,4\% (abr/05) a $34,3 \%$ (jun/05). Apenas na coleta do mês de julho de 2004, foi observado um acréscimo da condutividade da água após a passagem pelo canais $(2,6 \%)$.

Com relação aos solos filtrantes, exceto para a coleta do mês de fevereiro, março e de junho de 2004 e agosto de 2005, a eficiência foi positiva, com uma remoção que variou de $0,7 \%$ (fev/04) a $14,7 \%$ (jul).

Pode-se observar uma redução dos valores de condutividade da água, após a passagem pelo sistema de alagados construídos, em todo o período de estudo. A eficiência de remoção total do sistema variou de 7,4\% (mai/05) a 27,5\% (jun/05).

Segundo Esteves (1988), os íons mais diretamente responsáveis pelos valores de condutividade elétrica em águas interiores são os macronutrientes (cálcio, magnésio, potássio, sódio, carbonato, sulfato e cloreto, dentre outros), enquanto que o nitrato, nitrito e ortofosfato têm pouca importância.

Como já foi observado anteriormente nos dados de alcalinidade (bicarbonato), e dureza (cálcio e magnésio) em 2004 e nos de cloretos em 2004 e 2005, a concentração destes íons em sua maioria reduziram após a passagem pelo sistema (exceto a alcalinidade em julho e os cloretos em agosto e setembro de 2005).

A remoção pode ter ocorrido provavelmente pela absorção dos íons pela microbiota e macrófitas e também pelos processos de adsorção e troca catiônica. As cargas positivas do íon na solução (cálcio, magnésio, potássio) se ligam aos sítios 
carregados negativamente na superfície do material de adsorção, seja no solo ou nas próprias plantas.

O aumento da concentração de íons provavelmente ocorreu devido a morte e decomposição das macrófitas, com o retorno dos macronutrientes acumulados para a coluna d’água.

O sistema de alagados construídos apresentou uma eficiência de remoção total de 19,4\% em 2004 e de 14,9\% em 2005. Nogueira (2003) obteve 25\% de remoção após a passagem pelo sistema composto por solos filtrantes e canal de macrófitas. No tratamento secundário do chorume proveniente do aterro sanitário de Passo Fundo, Cecconello (2005), verificou uma eficiência de remoção que variou de 19,9 a 58,4\%.

\subsubsection{Cor}

Os valores da cor da água obtidos nos pontos de coleta em 2004 e 2005 estão representados na figura 34.

A cor medida na entrada do sistema em 2004 (P1) variou entre 100 UC (jul) e 175 UC (fev). Nas amostras coletadas no ponto 2 (P2), a cor da água variou entre 50 UC (jun) e 80 UC (jul) e na saída do sistema (P3), os valores encontrados ficaram na faixa de 50 UC (fev) a 150 UC (jun).

Em 2005, a cor no P1 variou entre 70 UC (mai) e 250 UC (mar), maior valor encontrado durante todo o trabalho. Nas amostras coletadas no ponto 2, a cor da água variou entre $30 \mathrm{UC}$ (jun/jul) e $130 \mathrm{UC}$ (abr) e no P3, os valores encontrados ficaram na faixa de 35 UC (jul) a $140 \mathrm{UC}$ (mai).

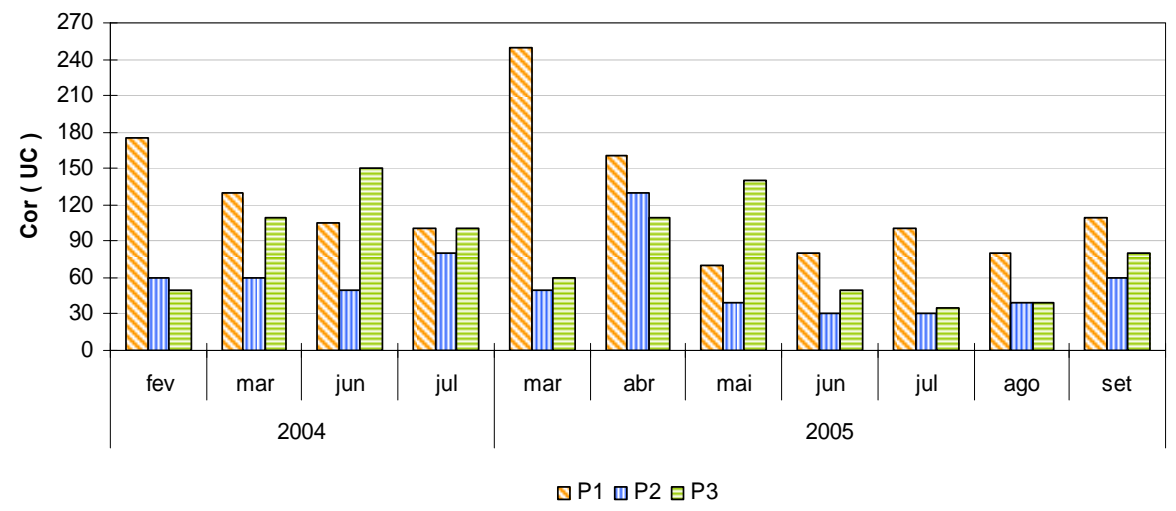

Figura 34: Variação dos valores de cor da água durante o período de coleta de 2004 e 2005 nas etapas do sistema de alagados construídos. 
Os resultados obtidos com a análise estatística SAS e Teste de Tukey podem ser observados na tabela 17. Letras distintas indicam diferenças significativas pelo Teste de Tukey a $5 \%(\mathrm{p} \leq 0,05)$.

Tabela 17: Resultado do Teste de Tukey para a variável cor

\begin{tabular}{ccc}
\hline \multirow{2}{*}{ Pontos } & \multicolumn{2}{c}{ Média (UC) } \\
& 2004 & 2005 \\
\hline 1 & $127,5 \mathrm{a}$ & $121,4 \mathrm{X}$ \\
2 & $62,5 \mathrm{~b}$ & $54,3 \mathrm{Y}$ \\
3 & $102,5 \mathrm{ab}$ & $73,6 \mathrm{XY}$ \\
\hline
\end{tabular}

Em 2004 e 2005, ao se comparar os valores médios da cor entre os pontos de coleta, pode-se afirmar, com um nível de significância de 5\%, que houve uma redução significativa somente após a passagem pelo conjunto de canais. P1 é diferente significativamente de $\mathrm{P} 2$, mas não de $\mathrm{P} 3$. O valor médio encontrado em P3 não é significativamente diferente do obtido em P2. A maior média de cor encontrada foi no P1, entrada do sistema, e a menor no P2, saída do canal de macrófitas.

As eficiências de remoção parcial e a total da cor da água, durante o período de estudo em 2004 e 2005, podem ser visualizadas na figura 35.

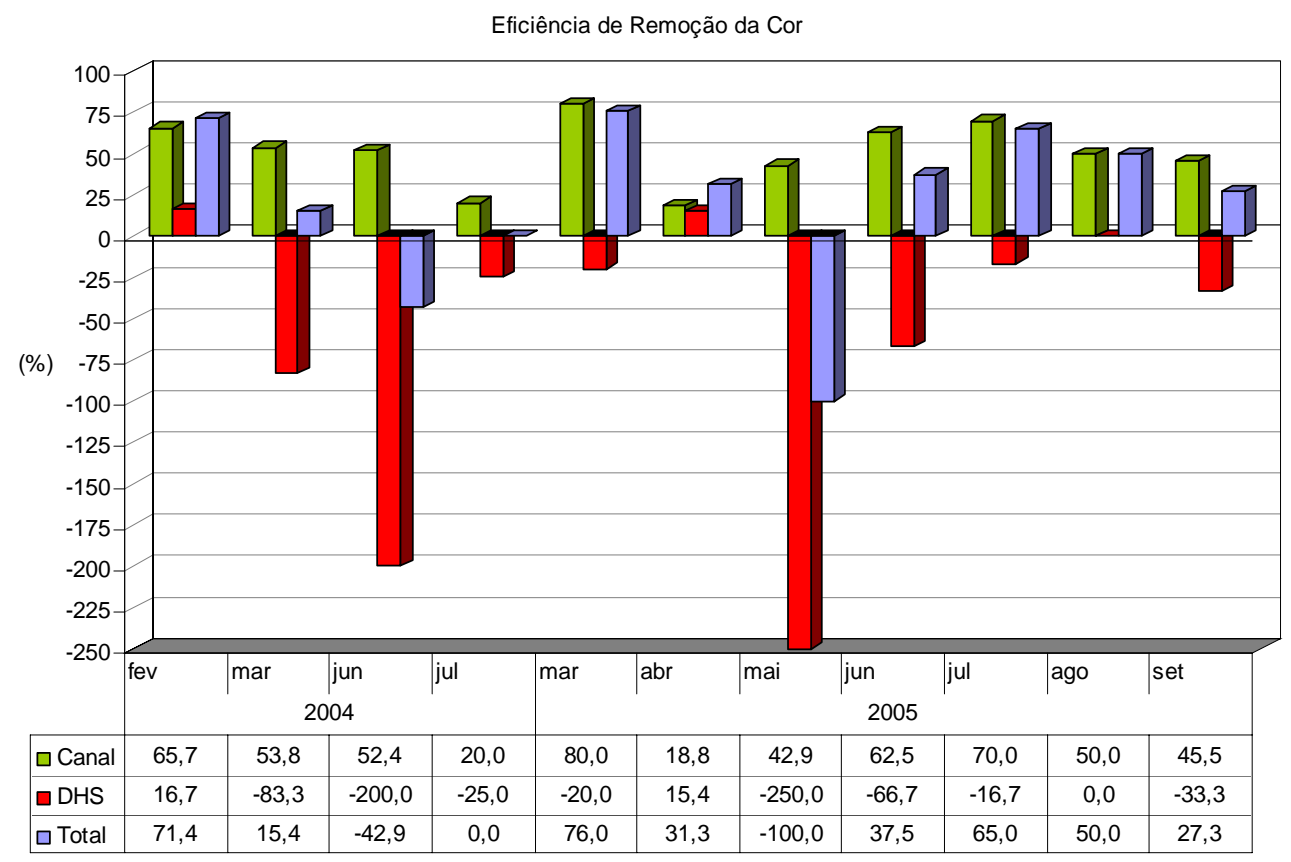

Figura 35: Eficiência total e de cada uma das etapas do sistema de alagados construídos na remoção da cor durante o período de coleta de 2004 e 2005. 
Após a passagem pelo canal de decantação e de macrófitas aquáticas houve uma redução da cor da água em todos os meses de coleta, com uma remoção que variou de $18,8 \%(\mathrm{abr} / 05)$ a $80 \%(\mathrm{mar} / 05)$.

Com relação aos solos filtrantes, exceto para a coleta do mês de fevereiro de $2004(16,7 \%)$ e abril de 2005 (15,4\%), a eficiência foi negativa, com um aumento na faixa de $16,7 \%$ (jul/05) a 250\% (mai/05) da cor da água na entrada no sistema DHS.

No entanto, ao se verificar a eficiência de remoção total do sistema, observou-se uma redução dos valores de cor após a passagem pelos alagados construídos na maioria dos meses de coleta, exceto para junho (-42,9\%) de 2004 e maio $(-100 \%)$ de 2005 . A eficiência total do sistema variou de $15,4 \%(\mathrm{mar} / 04)$ a $76 \%(\mathrm{mar} / 05)$. No mês de julho de 2004 não houve redução da cor.

As baixas eficiências de remoção para os meses de março (2004) e para a eficiência nula (jul/04) e negativa do sistema estão relacionadas ao baixo desempenho dos solos filtrantes para esta variável durante o estudo (falta de manejo)

O constituinte responsável pela cor da água são os sólidos dissolvidos, e, portanto, a diminuição dos valores desta variável na água ocorre devido aos processos de adsorção dos sólidos dissolvidos aos sítios das plantas e do solo, precipitação e coprecipitação com componentes insolúveis, oxidação pelos microrganismos e assimilação pelas plantas e microbiota (WATSON, et al., 1989).

$\mathrm{O}$ aumento da cor da água observado após a passagem pelos solos filtrantes provavelmente está relacionado à decomposição da matéria orgânica da água de entrada do sistema e da proveniente da morte das plantas e solubilização dos precipitados e das demais partículas, que voltam para a coluna de água com a ressuspensão do sedimento. (KADLEC et al., 2000). Segundo estes mesmo autores, os sedimentos e microdetritos dos alagados são facilmente perturbados pelos animais. No sistema de estudo, os animais do parque são atraídos pelo arroz e causam o revolvimento do solo.

No entanto, por ser um sistema combinado, a redução realizada pelo canal de decantação e de macrófitas contribuiu para uma remoção positiva total na maioria dos meses de coleta. A eficiência média de remoção total do sistema foi de 10,9\% para 2004 e de $26,7 \%$ para 2005.

Eficiências altas de remoção da cor são características dos alagados construídos, com taxas de remoção que chegam a ser superiores a 80\% (MANFRINATO, 1989). Salati e colaboradores (1999) reportaram eficiências de $46 \%$ para o sistema de Analândia e 75\% para a estação piloto de pré-tratamento da águas do Rio Cotia. 
A estação composta por um sistema de solos filtrantes e canal de macrófitas, utilizada para tratamento secundário do esgoto de um bairro de Ubatuba, é responsável pela remoção de $73 \%$ da cor do efluente (SALATI FILHO; SALATI, Eneida \& SALATI, Enéas, 1999).

A água coletado no ponto de entrada do sistema apresentou durante todo o período de estudo, valores acima dos estipulados para águas doces de classe 2 pela Resolução CONAMA 357/2005 (BRASIL, 2005). No entanto, após a passagem pelo conjunto de canais (2004 e 2005), o efluente atendeu em sua maioria a resolução (cor $<75$ UC). Em 2004, os solos não foram eficientes e somente a coleta de fevereiro apresentou um valor para cor inferior a 75UC. Em 2005, a maioria dos meses (exceto abril) apresentou um efluente que atendeu a resolução para classe 2.

\subsubsection{Turbidez}

A variação dos valores de turbidez da água em cada um dos pontos de coleta em 2004 e 2005 está representada na Figura 36.

Observa-se que na maioria dos meses de coleta, a turbidez medida na entrada do sistema de alagados (P1) apresentou valores mais altos quando comparados com os do efluente de saída (P3). Este fato só não foi evidenciado no mês de junho de 2004, em que a turbidez aumentou cerca de 4,1UNT após a passagem pelo alagado construído.

Em todos os meses de coleta de 2005, exceto abril, os valores encontrados na saída do canal de macrófitas (P2) foram os mais baixos quando comparados com os demais pontos.

A turbidez medida em 2004 na entrada do sistema (P1) variou entre 22,4 UNT (jun) e 69,8 UNT (jul), no ponto 2 entre 6,3 UNT (jun) e 11,1 UNT (fev) e na saída do sistema (P3), os valores ficaram na faixa de 6 UNT (fev) e 28,5 UNT (jun).

No ano de 2005, os valores em P1 variaram entre 17 UNT (ago) e 59,7 UNT (mai), no P2 entre 1,25 UNT (jun) e 23,6 UNT (abr), e no P3, os dados obtidos variaram entre 2,39 UNT (ago) e 10,5 UNT (abr). 


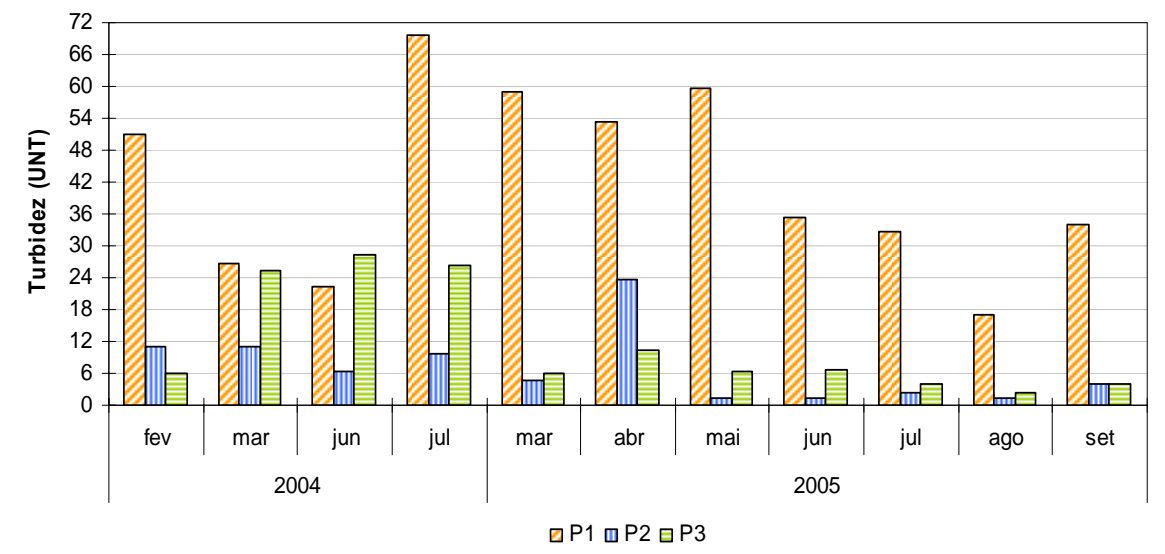

Figura 36: Variação dos valores de turbidez da água durante o período de coleta de 2004 e 2005 nas etapas do sistema de alagados construídos.

Os resultados obtidos com a análise estatística SAS e Teste de Tukey podem ser observados na tabela 18. Letras distintas indicam diferenças significativas pelo Teste de Tukey a $5 \%(\mathrm{p} \leq 0,05)$.

Tabela 18: Resultado do Teste de Tukey para a variável turbidez

\begin{tabular}{ccc}
\hline \multirow{2}{*}{ Pontos } & \multicolumn{2}{c}{ Média (UNT) } \\
& $\mathbf{2 0 0 4}$ & $\mathbf{2 0 0 5}$ \\
\hline 1 & $42,5 \mathrm{a}$ & $41,6 \mathrm{X}$ \\
2 & $9,48 \mathrm{~b}$ & $5,5 \mathrm{Y}$ \\
3 & $21,6 \mathrm{ab}$ & $5,7 \mathrm{Y}$ \\
\hline
\end{tabular}

Em 2004, ao se comparar os valores médios de turbidez entre os pontos, pode-se afirmar, com um nível de significância de 5\%, que houve uma remoção significativa somente após a passagem pelo canal de decantação e de MAFE, e um acréscimo após a passagem pelos solos filtrantes. A maior média encontrada foi no P1, entrada do sistema, e a menor no P2, saída do canal de macrófitas.

Já em 2005, observou-se, que o canal de decantação e o de macrófitas foram responsáveis por uma redução significativa da turbidez e os solos filtrantes foram indiferentes. Novamente, a maior média encontrada foi no ponto 1.

As eficiências de remoção parcial e total da turbidez da água, durante o período de estudo em 2004 e 2005, podem ser visualizadas na figura 37. 


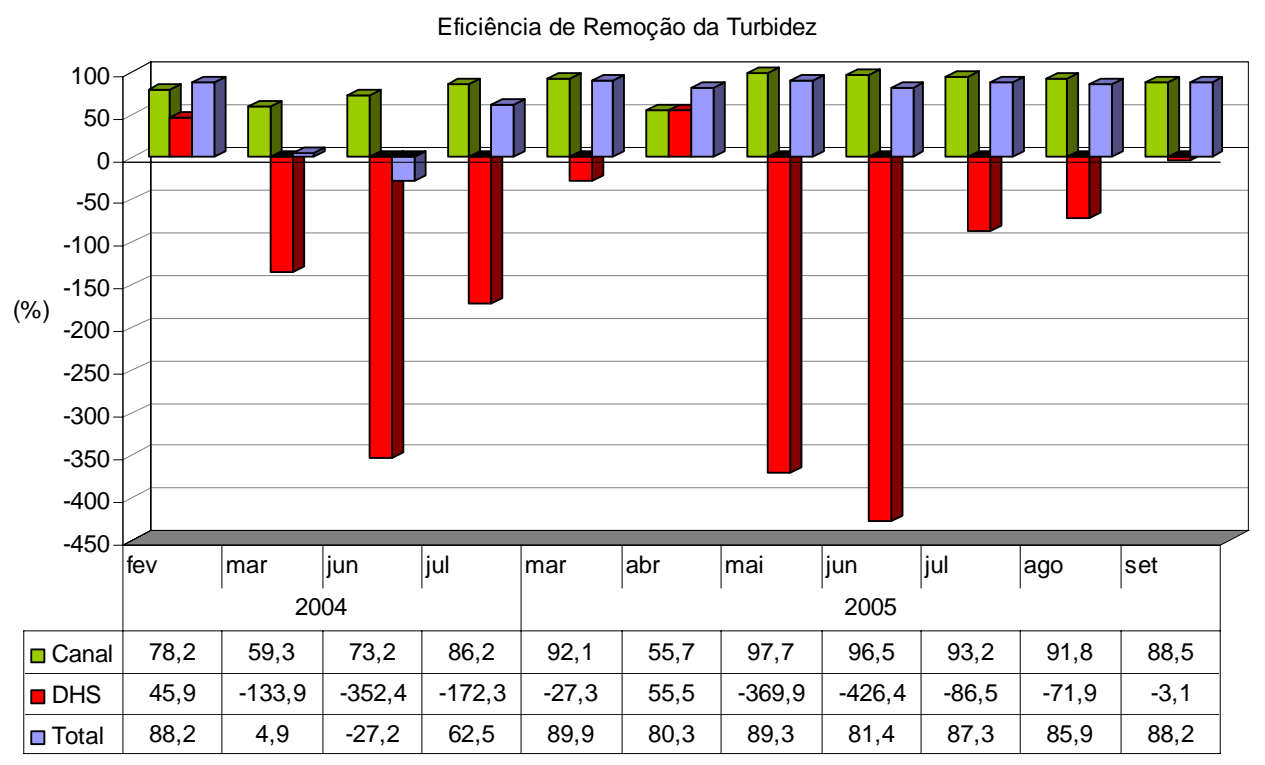

Figura 37: Eficiência total e de cada uma das etapas do sistema de alagados construídos na remoção da turbidez durante o período de coleta de 2004 e 2005.

Após a passagem pelos canais, houve uma redução da turbidez da água em todos os meses de coleta. A eficiência de remoção variou entre 55,7\% (abr/05) e 97,7\% (mai/05).

Com relação aos solos filtrantes, exceto para a coleta do mês de fevereiro de 2004 (taxa de remoção de 45,9\%) e abril de 2005 (55,5\%), o desempenho foi negativa, com um aumento na faixa de $3,1 \%$ (set/05) a 426,4\% (jun/05) do valor de entrada dos canteiros.

Pode-se observar uma redução dos valores da turbidez da água, após a passagem pelo sistema de alagados construídos, para todo período de estudo, exceto para a coleta do mês de junho de 2004 (-27,2\%). A eficiência de remoção total do sistema variou de $4,9 \%(\mathrm{mar} / 04)$ a $89,9 \%(\mathrm{mar} / 05)$.

As baixas eficiências de remoção para o mês de março (2004) e para a eficiência negativa do sistema em junho (2004) estão relacionadas ao desempenho não satisfatório dos solos filtrantes para esta variável durante o estudo (falta de manejo do sistema), enquanto a que performance do sistema, com eficiência média superior a $80 \%$ para os demais meses, está relacionada ao grande desempenho do canal de decantação e de macrófitas no início do sistema. 
A remoção da turbidez ocorre através dos processos de filtragem, sedimentação, assimilação pelas plantas e metabolismo microbiano (KADLEC et al., 2000; WATSON et al., 1989). Já o aumento da turbidez da água, observado após a passagem pelos solos filtrantes, provavelmente está relacionado à decomposição da matéria orgânica (principalmente vegetais - ácidos húmicos - que não foram retirados do sistema), fragmentação de detritos de plantas e algas, formação de precipitados químicos e principalmente ao revolvimento do solo (KADLEC et. al, 2000) pelos animais do parque que visitam o sistema além dos macroinvertebrados bentônicos.

Acredita-se que interferência dos animais do parque ecológico, atraídos pelo arroz (macaco-prego, quatis, pacas) também possa ter sido responsável pelo revolvimento do sedimento e ressuspensão das partículas, uma vez que o sistema encontra-se aberto. Segundo Kadlec e colaboradores (2000), os sedimentos e microdetritos dos alagados são facilmente perturbados e os animais podem ser fortes determinantes para o aumento da concentração de sólidos suspensos totais.

A eficiência média de remoção total do sistema foi de 32,1\% para 2004 e de $86 \%$ para 2005. Eficiências altas de remoção da turbidez também são características dos alagados construídos. Manfrinato (1989), estudando o tratamento de esgoto doméstico em Piracicaba, obteve eficiências positivas em todo o período de estudo com uma taxa que variou de 50 a 94,4\%. Salati e colaboradores (1999) reportaram eficiência de 100\% para a estação piloto de pré-tratamento da águas do Rio Cotia enquanto que Elias (2003), alcançou taxas de remoção que variaram de 70 a 91\% de acordo com a estação do ano na ETA de Analândia.

A estação para tratamento secundário de esgoto doméstico, do bairro de Emaús em Ubatuba, apresentou uma redução de 95\% da turbidez (SALATI FILHO; SALATI, Eneida \& SALATI, Enéas, 1999). O estudo realizado por Valentim (2003), no tratamento de efluentes de tanque séptico com canais de macrófitas emergentes, apresentou taxas de remoção que variaram de 39 a 85\%. Jucá (2003), por sua vez, observou uma taxa de remoção média de $27,9 \%$ da turbidez do efluente do aterro sanitário de Muribeca após a passagem por um canal de macrófitas emergentes.

Durante o período de estudo de 2004 e 2005, os dados encontrados para turbidez em todos os pontos de coleta atendem a Resolução CONAMA 357/2005 (BRASIL, 2005) para águas doces de classe 2, apresentando valores abaixo de 100UNT. 


\subsubsection{Sólidos Totais}

Os valores da concentração de sólidos totais da água obtidos nos pontos de coleta em 2004 estão representados na figura 38. Segundo a SABESP, os ensaios de fevereiro foram prejudicados.

A concentração medida em 2004 na entrada do alagado (P1) variou entre 158mg.L $\mathrm{L}^{-1}$ (jun) e $194 \mathrm{mg} . \mathrm{L}^{-1}$ (mar), entre $164 \mathrm{mg} . \mathrm{L}^{-1}$ (mar) e $308 \mathrm{mg} . \mathrm{L}^{-1}$ (jul) no ponto 2 e, na saída do sistema (P3), entre 112mg. $\mathrm{L}^{-1}$ (jul) e 194mg.L $\mathrm{L}^{-1}$ (jun).

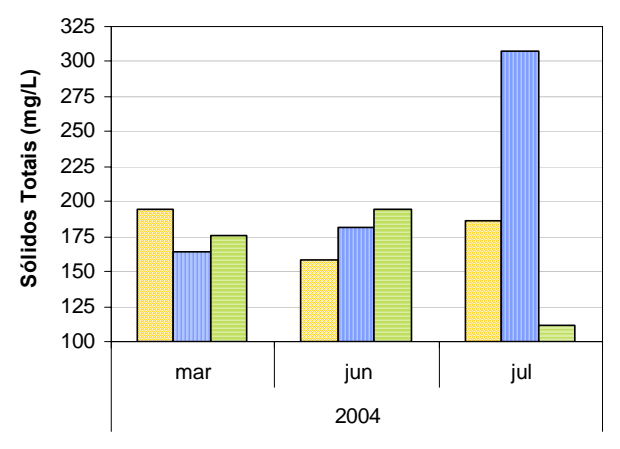

口P1 वP2 वP3

Figura 38: Variação dos valores de sólidos totais da água durante o período de coleta de 2004 nas etapas do sistema de alagados construídos.

Os resultados obtidos com a análise estatística SAS e Teste de Tukey podem ser observados na tabela 19. Letras distintas indicam diferenças significativas pelo Teste de Tukey a $5 \%(\mathrm{p} \leq 0,05)$.

Tabela 19: Resultado do Teste de Tukey para a variável sólidos totais.

\begin{tabular}{cc}
\hline Pontos & $\begin{array}{c}\text { Média (mg.L } \\
\mathbf{2 1}\end{array}$ \\
& $\mathbf{2 0 0 4}$ \\
\hline 1 & $179 \mathrm{a}$ \\
2 & $185 \mathrm{a}$ \\
3 & $127 \mathrm{a}$ \\
\hline
\end{tabular}

Os valores médios, encontrados em cada ponto de coleta, mostram um aumento da concentração de sólidos totais após a passagem pelos canais e uma redução após os solos filtrantes. Segundo o teste estatístico não há diferença significativa entre as médias encontradas, no entanto, percebe-se um aumento considerável de sólidos totais após a passagem pelo sistema de canais em julho, e uma remoção também considerável por parte dos solos filtrantes.

As eficiências de remoção parcial e a total de sólidos totais da água, durante o período de estudo em 2004, podem ser visualizadas na figura 39. 


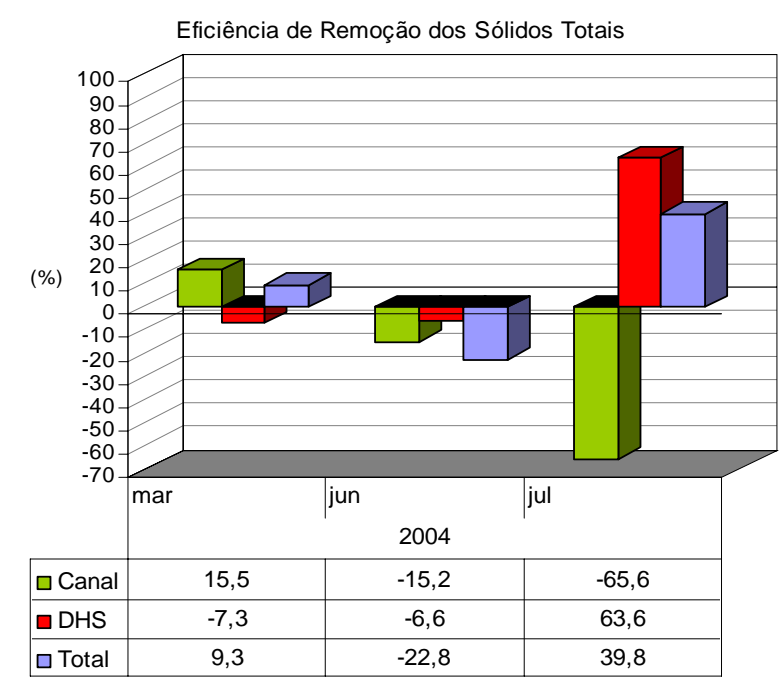

Figura 39: Eficiência total e de cada uma das etapas do sistema de alagados construídos na remoção de sólidos totais durante o período de coleta de 2004.

O canal de decantação e o de macrófitas apresentaram um desempenho positivo de remoção somente no mês de março $(15,5 \%)$. Nos meses de junho e julho foi observado um acréscimo da concentração de sólidos totais na água, taxa de 15,2\% e $65,6 \%$ respectivamente.

Com relação aos solos filtrantes, notou-se uma eficiência de remoção dos sólidos totais somente na coleta de julho $(63,6 \%)$. Um acréscimo da concentração foi observado nas coletas em março $(17,3 \%)$ e junho $(6,6 \%)$.

A taxa de remoção total do sistema foi positiva para os meses de março $(9,3 \%)$ e de julho $(39,8 \%)$. No entanto para a coleta do mês de junho, observou-se um acréscimo concentração de sólidos totais $(22,8 \%)$ após a passagem pelos alagados construídos.

A remoção dos sólidos totais ocorre através da sedimentação, filtração pelas raízes das macrófitas e pelo substrato (KADLEC et al., 2000) e decomposição dos sólidos suspensos, como já citado anteriormente para a variável turbidez. E também através da assimilação pelas plantas e microbiota, adsorção ao solo e aos sítios das macrófitas, precipitação e co-precipitação com componentes insolúveis, oxidação pelos microrganismos e assimilação pelas plantas e microbiota (WATSON, et al., 1989).

$\mathrm{O}$ aumento da concentração nos canais e nos solos filtrantes pode estar relacionado com a morte dos invertebrados, fragmentação e decomposição de plantas e algas, e formação de precipitados químicos (sulfetos, hidróxidos) que voltam para a coluna de água com o revolvimento do solo. Durante o período de estudo, não foi 
encontrado nenhum fator que explicasse esse aumento em julho após a passagem pelo sistema de canais que o diferenciasse dos demais meses, por isso acredita-se que tenha ocorrido um erro na análise da amostra.

A eficiência de remoção total média do sistema foi de 8,8\%. Salati e colaboradores (1999) ao analisarem a eficiência da estação de Analândia verificaram uma remoção de $45 \%$ após a passagem pelo sistema de alagados. O tratamento de águas residuárias provenientes do escoamento rural da pecuária leiteira, com alagados construídos foi responsável pela remoção de 28 a 35\% dos sólidos totais (KADLEC et al., 2000). Cecconello (2005), trabalhando com tratamento de percolados de aterro sanitário, verificou uma taxa de remoção que variou de 15,1 a 76,2\% após a passagem por canais de macrófitas emergentes.

No entanto, os trabalhos envolvendo a eficiência de remoção de sólidos estão mais relacionados aos sólidos suspensos do que totais. No pré-tratamento das águas do Rio Cotia, uma taxa superior a 48,7\% foi encontrada (SALATI et al., 1999). Já para a remoção de sólidos suspensos totais de efluentes domésticos, observam taxas que variam de 40 a 93,5\% (DEBUSK \& MERRICK ${ }^{17}, 1989$ apud KADLEC, et al., 2000; VALENTIM, 2003).

Apesar de não haver na Resolução CONAMA 357/2005, um limite estabelecido para sólidos totais, pode-se encontrar o parâmetro sólidos em suspensão (limite até 500mg. $\left.\mathrm{L}^{-1}\right)$. Por isso, é possível inferir neste trabalho, que com relação aos sólidos, o efluente pode ser enquadrado em corpos de água de classe 2, uma vez que apresenta concentração para sólidos totais abaixo de $500 \mathrm{mg} \cdot \mathrm{L}^{-1}$.

\subsubsection{Demanda Bioquímica de Oxigênio $\left(\mathrm{DBO}_{5}\right)$}

A variação dos valores de $\mathrm{DBO}_{5}$ da água em cada um dos pontos de coleta em 2004 está representada na Figura 40.

Os dados obtidos nas análises mostram que na maioria dos meses de coleta, o ponto de entrada do sistema (P1) apresentou valores mais altos da variável, enquanto que o ponto de saída (P3) apresentou os mais baixos. Este fato só não pode ser evidenciado no mês de julho, no qual a $\mathrm{DBO}_{5}$ da água aumentou após a passagem pelos solos filtrantes.

${ }^{17}$ DEBUSK, T; MERRICK, P. (1989). Summary of operational and research data for the Reddy Creek improvement district wetland-based wastewater treatment system (WTS2). Report of March. 
A $\mathrm{DBO}_{5}$ medida na entrada do alagado (P1) variou entre $13,5 \mathrm{mg} \cdot \mathrm{L}^{-1}$ (jul) e $15,2 \mathrm{mg} . \mathrm{L}^{-1}$ (mar), entre $6 \mathrm{mg} . \mathrm{L}^{-1}$ (jul) e $10 \mathrm{mg} . \mathrm{L}^{-1}$ (fev) no ponto 2 e, na saída do sistema (P3), ficou na faixa de $7 \mathrm{mg} . \mathrm{L}^{-1}$ (fev e jul) a $8,1 \mathrm{mg} \cdot \mathrm{L}^{-1}$ (mar).

A $\mathrm{DBO}_{5}$ medida na coleta do mês de junho apresentou em todos os pontos um valor inferior a $5 \mathrm{mg} . \mathrm{L}^{-1}$ (limite de quantificação do método).

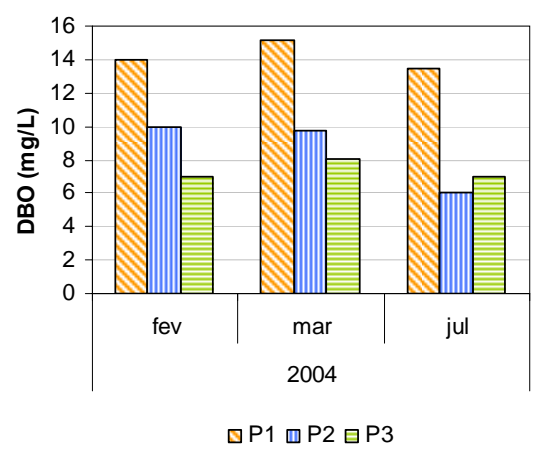

Figura 40: Variação dos valores de $\mathrm{DBO}_{5}$ durante o período de coleta de 2004 nas etapas do sistema de alagados construídos.

Os resultados obtidos com a análise estatística SAS e Teste de Tukey podem ser observados na tabela 20. Letras distintas indicam diferenças significativas pelo Teste de Tukey a $5 \%(\mathrm{p} \leq 0,05)$.

Tabela 20: Resultado do Teste de Tukey para a variável $\mathrm{DBO}_{5}$

\begin{tabular}{cc}
\hline Pontos & $\begin{array}{c}\text { Média (mg. } \mathbf{L}^{-\mathbf{1}} \text { ) } \\
\mathbf{2 0 0 4}\end{array}$ \\
\hline 1 & $11,7 \mathrm{a}$ \\
2 & $7,5 \mathrm{a}$ \\
3 & $6,0 \mathrm{a}$ \\
\hline
\end{tabular}

Apesar do maior valor médio de $\mathrm{DBO}_{5}$ ter sido encontrado no ponto de entrada $\left(11,7 \mathrm{mg} . \mathrm{L}^{-1}\right)$ e o menor no ponto de saída do sistema $\left(6,0 \mathrm{mg} \cdot \mathrm{L}^{-1}\right)$, pode-se afirmar com um nível de 5\% de significância, que não há diferença significativa entre os pontos de coleta.

As eficiências de remoção parcial e a total da dureza da água, durante o período de estudo em 2004, podem ser visualizadas na figura 41. 


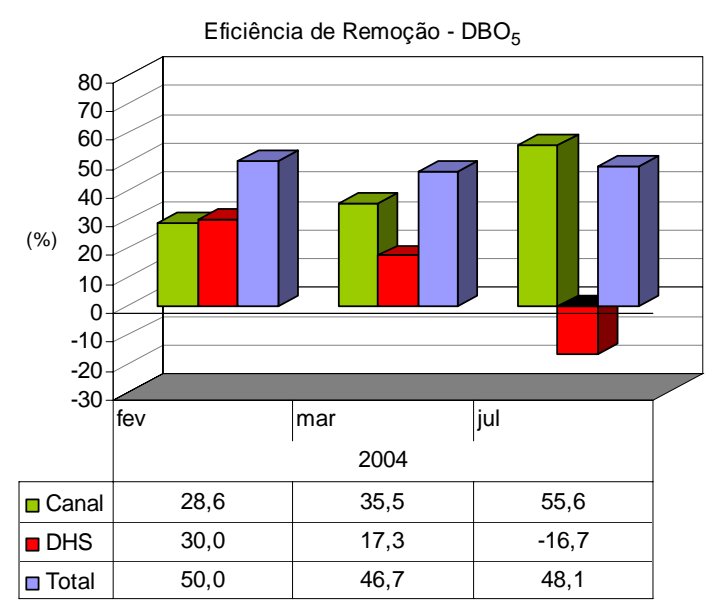

Figura 41: Eficiência total e de cada uma das etapas do sistema de alagados construídos na remoção da $\mathrm{DBO}_{5}$ durante o período de coleta de 2004.

O conjunto de canais apresentou um desempenho satisfatório de remoção durante o período de estudo, com uma eficiência que variou entre 28,6\% (fev) e 55,6\% (jul).

Os solos filtrantes apresentaram uma taxa de remoção positiva nos meses de fevereiro e março, $30 \%$ e $17,3 \%$ respectivamente. No entanto, foi observado um acréscimo de $16,7 \%$ do valor da $\mathrm{DBO}_{5}$ no efluente após a passagem pelos solos filtrantes no mês de julho.

A eficiência de remoção total do sistema variou de 46,7\% (março) a 50\% (fevereiro). Como pode ser observado, o valor encontrado após a passagem pelo sistema de alagados construídos é cerca de 50\% mais baixo. Por isso, apesar do teste mostrar que os pontos não são significativamente diferentes, aceita-se que há uma remoção significativa após a passagem pelo sistema.

Segundo Kadlec e colaboradores (2000), a redução da $\mathrm{DBO}_{5}$ nos alagados ocorre através dos processos de filtração e deposição das partículas orgânicas sedimentáveis, e degradação microbiana (aeróbia e anaeróbia) dos componentes orgânicos solúveis. O oxigênio necessário para a degradação aeróbia é fornecido diretamente pela atmosfera por difusão ou liberado pelas raízes das macrófitas (rizosfera). A assimilação da matéria orgânica pelas macrófitas é desprezível quando comparada com a degradação biológica (Watson et al., 1989).

O acréscimo, após a passagem pelos solos filtrantes, possivelmente está relacionado ao revolvimento do solo (já citado anteriormente para turbidez e cor), a morte e decaimento das plantas e condição de anaerobiose das células. Há um aumento 
da matéria orgânica morta no sistema, mas a falta de oxigênio limita a degradação aeróbia.

Provavelmente a remoção no sistema de estudo não tenha sido significativa devido ao fato do aguapé e do alface d’água não terem se adaptado no período de teste de 2004 (aumento da carga orgânica em decomposição), e também por ser um sistema ainda jovem (iniciante).

Segundo Kadlec e demais colaboradores (2000), o período de adaptação do sistema inclui o preenchimento dos canais com macrófitas, o desenvolvimento das raízes, aumento da matéria morta sedimentada (litter) e o estabelecimento da comunidade microbiana, no entanto, a presença de um sistema coberto por plantas crescidas e maduras, embora necessária, não é o suficiente para a redução da $\mathrm{DBO}_{5}$.

A eficiência média de remoção do sistema foi de 48,2\% em 2004. Existem muitos estudos com relação à eficiência de sistemas de alagados para remoção da $\mathrm{DBO}_{5}$. Como exemplo, pode-se citar os trabalhos desenvolvidos por Gersberg e colaboradores (1989) e Steiner e Combs (1993) para tratamento secundário de efluentes domésticos com macrófitas emergentes, que apresentaram eficiências médias de remoção de $90 \%$ e $89 \%$.

No bairro de Emaús, cerca de 96,3\% da $\mathrm{DBO}_{5}$ foi removida (SALATI FILHO; SALATI, Eneida \& SALATI, Enéas, 1999). Newman e colaboradores (2000) e Nogueira (2003) verificaram uma remoção média superior a 70\% em efluentes de escoamento rural (produção leiteira) e doméstico, respectivamente, após a passagem por um sistema de alagados construídos.

A estação de tratamento de água de Analândia apresentou taxas de remoção que variaram entre 7,4\% (inverno) e 31,8\% (primavera)(ELIAS, 2003). No tratamento de percolados de aterro sanitário, Jucá (2003) e Cecconello (2005) observaram taxas de remoção superiores a $41 \%$.

Dados operacionais das wetlands em banco de dados indicam que a média da concentração desta variável no efluente de saída dos alagados é de aproximadamente 10,5mg. $\mathrm{L}^{-1}$, com valores na faixa de 1 a $50 \mathrm{mg} . \mathrm{L}^{-1}$. A eficiência de remoção é de $70 \%$ ou mais para cargas de entrada acima de $280 \mathrm{~kg} / \mathrm{ha}$./dia. Taxas mais baixas podem ocorrer, especialmente quando as cargas são menores do que 50kg/ha./dia (Knight et al., 1993).

Durante o período de estudo de 2004, a maioria das coletas (exceto junho) apresentou valores de $\mathrm{DBO}_{5}$ acima do limite $\left(5 \mathrm{mg} . \mathrm{L}^{-1}\right)$ estabelecido pela Resolução CONAMA 357/2005 (BRASIL, 2005) para águas doces classe 2. 


\subsubsection{Demanda Química de Oxigênio (DQO)}

Os valores da DQO da água obtidos nos pontos de coleta em 2004 e 2005 estão representados na figura 42 .

Os dados obtidos nas análises mostram que em todos os meses de coleta, houve uma redução da DQO na água após a passagem pelo sistema de alagados construídos.

Os valores em 2004 na entrada do alagado (P1) variaram entre $65 \mathrm{mg} . \mathrm{L}^{-1}$ (jun) e $108 \mathrm{mg} . \mathrm{L}^{-1}$ (jul). Nas amostras coletadas no ponto 2, a DQO variou entre $52 \mathrm{mg} . \mathrm{L}^{-1}$ (jun) e $68 \mathrm{mg} . \mathrm{L}^{-1}(\mathrm{jul})$ e, na saída do sistema (P3), ficaram na faixa de $38 \mathrm{mg} . \mathrm{L}^{-1}$ (jun) a $56 \mathrm{mg} . \mathrm{L}^{-1}(\mathrm{fev})$.

Em 2005, a DQO no P1 variou entre 43mg. $\mathrm{L}^{-1}$ (ago) e $98 \mathrm{mg} . \mathrm{L}^{-1}$ (mar), maior valor encontrado durante todo o trabalho. Nas amostras coletadas no ponto 2, a DQO da água variou entre $23 \mathrm{mg} . \mathrm{L}^{-1}$ (jul) e $73 \mathrm{mg} . \mathrm{L}^{-1}$ (abr) e no P3, os valores encontrados ficaram na faixa de $7 \mathrm{mg} . \mathrm{L}^{-1}$ (abr) a $42 \mathrm{mg} . \mathrm{L}^{-1}$ (mai).

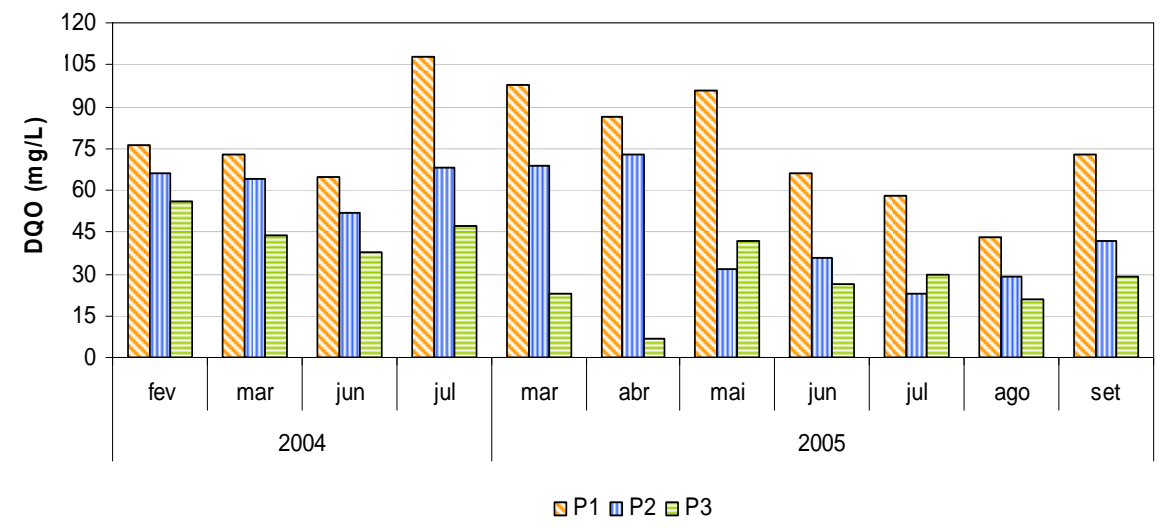

Figura 42: Variação dos valores de DQO da água durante o período de coleta de 2004 e 2005 nas etapas do sistema de alagados construídos.

Os resultados obtidos com a análise estatística SAS e Teste de Tukey podem ser observados na tabela 21. Letras distintas indicam diferenças significativas pelo Teste de Tukey a $5 \%(\mathrm{p} \leq 0,05)$.

Tabela 21: Resultado do Teste de Tukey para a variável DQO.

\begin{tabular}{ccc}
\hline \multirow{2}{*}{ Pontos } & \multicolumn{2}{c}{ Média (mg. $\mathbf{L}^{\mathbf{- 1}}$ ) } \\
& $\mathbf{2 0 0 4}$ & $\mathbf{2 0 0 5}$ \\
\hline 1 & $80,5 \mathrm{a}$ & $74,3 \mathrm{X}$ \\
2 & $62,5 \mathrm{ab}$ & $43,4 \mathrm{Y}$ \\
3 & $46,3 \mathrm{~b}$ & $25,4 \mathrm{Y}$ \\
\hline
\end{tabular}


Em 2004, ao se comparar os valores médios de DQO entre os pontos, pode-se afirmar com um nível de significância de 5\%, que houve uma redução significativa somente após a passagem pelo sistema. Uma vez que P1 é significativamente diferente de P3, mas não de P2, e o valor médio encontrado em P2 não é significativamente diferente ao obtido em P3. A maior média encontrada foi no P1 e a menor no P3.

Em 2005, observou-se que o P2 e o P3 não são significativamente diferentes entre si, mas se diferem do P1, havendo, portanto, uma remoção significativa da DQO após a passagem pelos canais. Novamente, a maior média encontrada foi no P1 e a menor no P3.

As eficiências de remoção parcial e a total da DQO da água, durante o período de estudo em 2004 e 2005, podem ser visualizadas na figura 43.

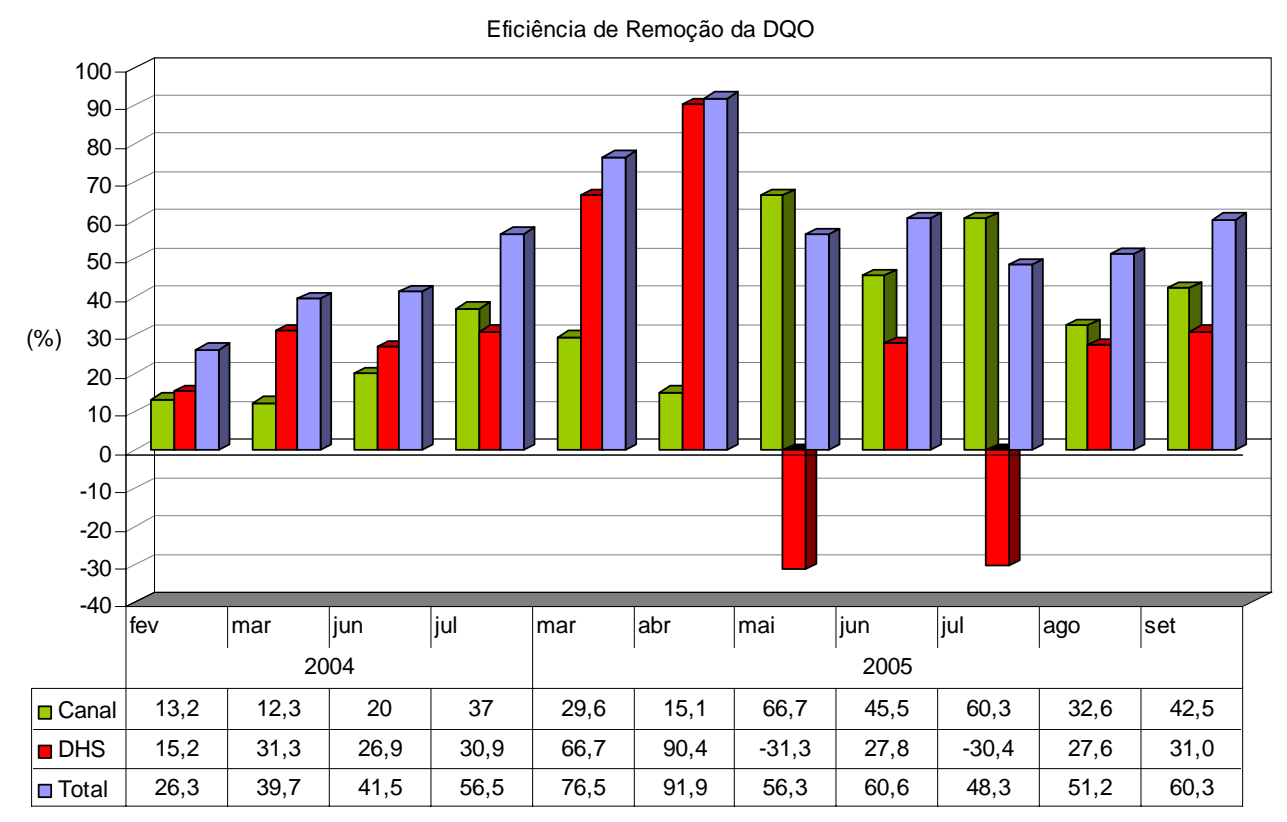

Figura 43: Eficiência total e de cada uma das etapas do sistema de alagados construídos na remoção da DQO durante o período de coleta de 2004 e 2005.

Os canais de decantação e de macrófitas apresentaram uma eficiência de remoção positiva da DQO para todos os meses de coleta. A taxa de remoção variou na faixa de $12,3 \%(\mathrm{mar} / 04)$ a $66,7 \%(\mathrm{mai} / 05)$.

O sistema de solos filtrantes mostrou-se eficiente na remoção da DQO da água para a maioria dos meses de coleta. A taxa de remoção variou na faixa de $15,2 \%$ (fev/04) a 90,4\% (abr/05). Apenas nas coletas do mês de maio (-31,3\%) e julho(-30,4\%) de 2005, foi observado um acréscimo da DQO. 
Todos os meses de coleta apresentaram uma taxa de eficiência de remoção total positiva. A taxa de remoção variou entre 26,3\% (fev/04) e 91,9\% (abr/05).

Os processos de remoção da matéria orgânica já foram citados anteriormente para $\mathrm{DBO}_{5}$. No entanto, o aumento da DQO observada após a passagem pelos solos filtrantes pode estar relacionado à ressuspensão do material sedimentado no solo (presença de animais por causa do arroz), à morte e decaimento das macrófitas somadas a possível ausência de oxigênio, limitando a degradação aeróbia.

A eficiência média de remoção foi de 41,5\% em 2004 e 63,6\% em 2005. Salati e colabores (1999) reportaram uma taxa de remoção 26,1\% da DQO das águas do Rio Cotia após a passagem por uma estação combinada de alagados construídos com canal de macrófitas e solos filtrantes.

Netter (1993), Nogueira (2003) e Valentim (2003) em seus estudos com águas de esgoto, tratadas primariamente com tanque séptico, observaram taxas de remoção superiores a $95 \%, 76 \%$ e $50 \%$ da DQO, respectivamente após a passagem por alagados construídos.

Elias (2003) também observou um acréscimo de 16,7\% e 48,4\% da DQO após a passagem pelo canal de macrófitas (primavera) e pelos solos filtrantes (outono) respectivamente, em Analândia.

\subsubsection{Nutrientes}

\subsubsection{Fósforo Total}

A variação dos valores de fósforo total da água em cada um dos pontos de coleta em 2004 e 2005 está representada na Figura 44.

A concentração de fósforo medida na entrada do sistema (P1) variou entre 0,067mg.L-1 (jun) e $0,128 \mathrm{mg} . \mathrm{L}^{-1}$ (fev), na faixa de $0,031 \mathrm{mg} / \mathrm{L}^{-1}$ (fev) a $0,053 \mathrm{mg} . \mathrm{L}^{-1}$ (mar) no ponto $2 \mathrm{e}$, na saída do sistema (P3) variou entre $0,04 \mathrm{mg} . \mathrm{L}^{-1}$ (jun) a 0,058mg. $\mathrm{L}^{-1}(\mathrm{fev})$.

No ano de 2005, os valores em P1 variaram entre $0,084 \mathrm{mg} / \mathrm{L}^{-1}$ (jul/ago) e $0,14 \mathrm{mg} / \mathrm{L}^{-1}$ (mar), no P2 entre $0,023 \mathrm{mg} / \mathrm{L}^{-1}$ (jul) e $0,143 \mathrm{mg} / \mathrm{L}^{-1}$ (mar), e no P3 de 0,024 $\mathrm{mg} / \mathrm{L}^{-1}$ (jul) a $0,046 \mathrm{mg} / \mathrm{L}^{-1}$ (abr). 


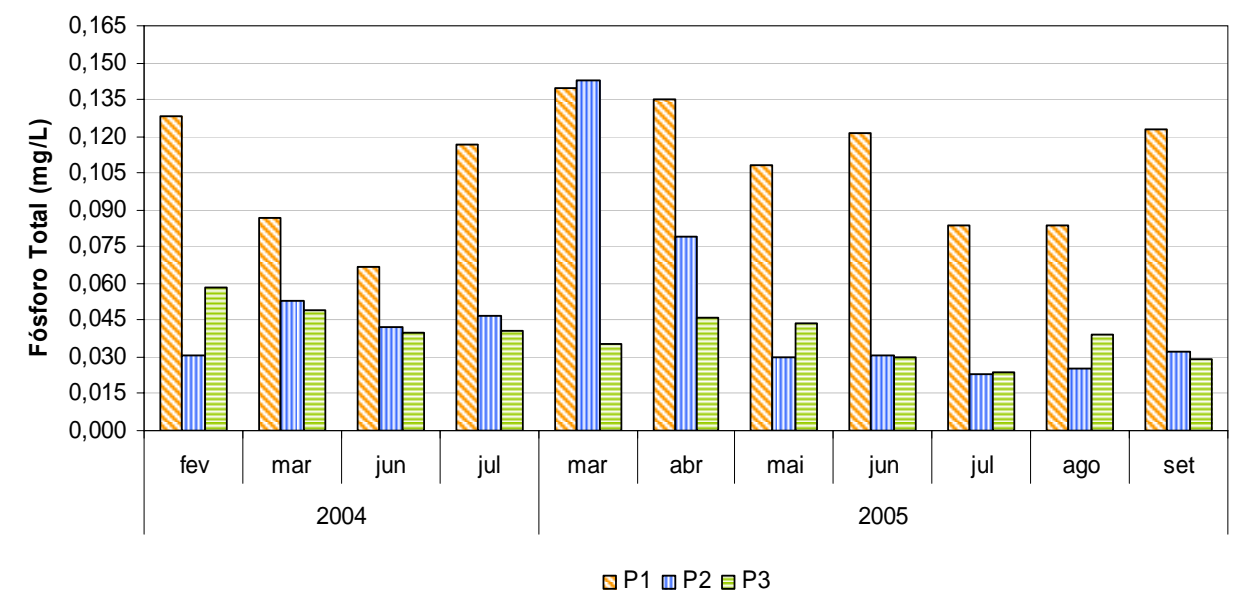

Figura 44: Variação dos valores de fósforo total da água durante o período de coleta de 2004 e 2005 nas etapas do sistema de alagados construídos.

Observou-se que em todos os meses de coleta de 2004 e 2005, o ponto de entrada do sistema (P1) foi o que apresentou a maior concentração de fósforo total quando comparado com os demais pontos. Este fato só não foi evidenciado no mês de março de 2005, período em que o valor encontrado no ponto 2 foi superior.

Os resultados obtidos com a análise estatística SAS e Teste de Tukey podem ser observados na tabela 22. Letras distintas indicam diferenças significativas pelo Teste de Tukey a $5 \%(\mathrm{p} \leq 0,05)$.

Tabela 22: Resultado do Teste de Tukey para a variável fósforo total

\begin{tabular}{ccc}
\hline \multirow{2}{*}{ Pontos } & \multicolumn{2}{c}{ Média (mg.L $\mathbf{L}^{\mathbf{- 1}}$ ) } \\
& $\mathbf{2 0 0 4}$ & $\mathbf{2 0 0 5}$ \\
\hline 1 & $0,100 \mathrm{a}$ & $0,114 \mathrm{X}$ \\
2 & $0,043 \mathrm{~b}$ & $0,052 \mathrm{Y}$ \\
3 & $0,047 \mathrm{~b}$ & $0,035 \mathrm{Y}$ \\
\hline
\end{tabular}

Os valores médios da concentração de fósforo total nos pontos de coleta mostram uma remoção significativa após a passagem pelos canais tanto em 2004 quanto em 2005. Apesar do aumento observado no ano de 2004 após a passagem pelos solos filtrantes e a redução em 2005, não há diferenças significativas entre o P2 e o P3. A maior média encontrada foi de $0,10 \mathrm{mg} . \mathrm{L}^{-1}$ para 2004 e $0,114 \mathrm{mg} . \mathrm{L}^{-1}$ para 2005. O menor valor encontrado em 2004 foi no P2, efluente de saída do canal de macrófitas (0,043mg.L $\left.\mathrm{L}^{-1}\right)$ e em 2005, foi no P3, efluente de saída do sistema de alagados construídos $\left(0,035 \mathrm{mg} \cdot \mathrm{L}^{-1}\right)$. 
As eficiências de remoção parcial e a total de fósforo total da água, durante o período de estudo em 2004 e 2005, podem ser visualizadas na figura 45.

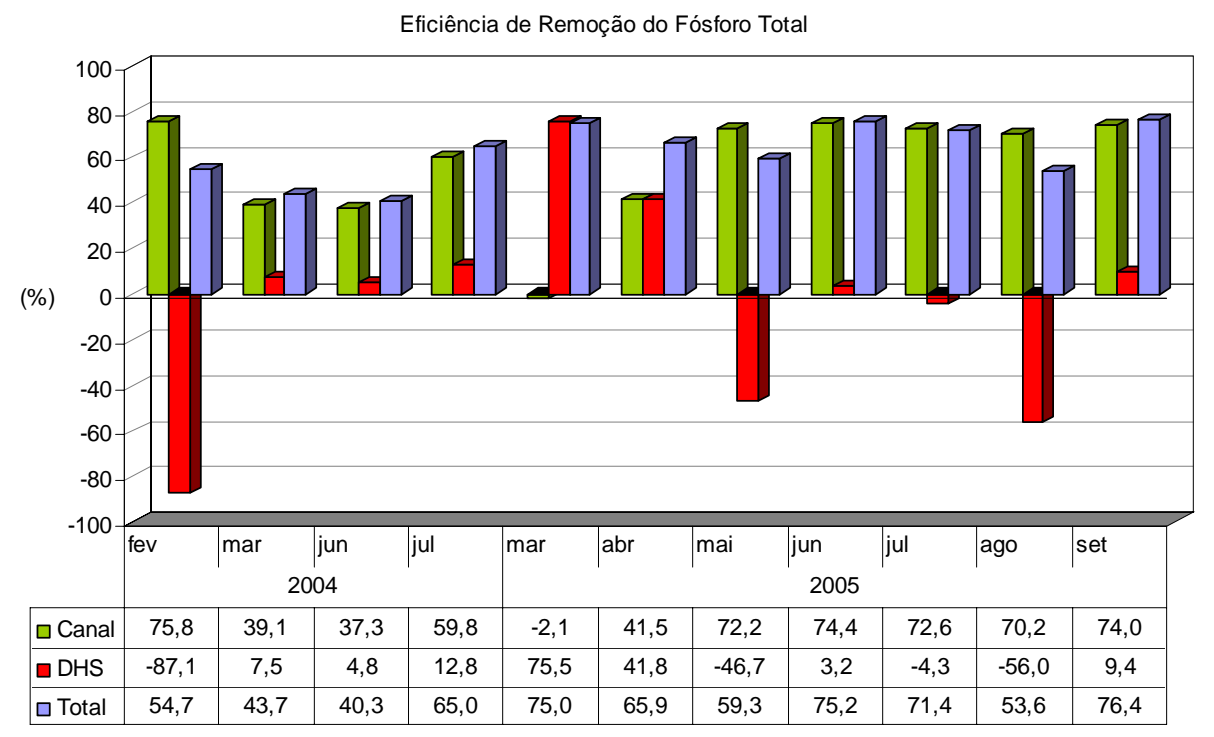

Figura 45: Eficiência total e de cada uma das etapas do sistema de alagados construídos na remoção de fósforo total durante o período de coleta de 2004 e 2005.

Os canais de decantação e de macrófitas apresentaram uma eficiência positiva de remoção da concentração de fósforo total da água para todos meses de coleta, com exceção o do mês de março, em que foi observado um acréscimo de $2,1 \%$. A taxa de remoção variou na faixa de 37,3\% (jun/04) a 75,8\% (fev/04).

O sistema de solos filtrantes também apresentou uma taxa positiva de remoção para a maioria dos meses de coleta. A eficiência de remoção variou na faixa de 3,2\% (jun/05) a 75,5\% (mar/05). Apenas nas coletas do mês de fevereiro de 2004 (-87,1\%), maio $(-46,7 \%)$ e agosto $(-56 \%)$ de 2005 , foram observados acréscimos da concentração de fósforo total da água após a passagem pelos canteiros de arroz.

Todos os meses de coleta apresentaram uma taxa de eficiência total de remoção positiva após a passagem pelo sistema combinado de alagados construídos. A taxa de remoção variou entre 40,3\% (jun/04) e 76,4\% (set/05).

As reações de adsorção e precipitação são os principais mecanismos de remoção do fósforo total da água, quando esta tem oportunidade de entrar em contato com uma parte significativa do sedimento (REED, CRITES \& MIDDLEBROOKS, 1995). No sedimento, o fosfato pode ser precipitado na forma insolúvel de fosfato férrico, de alumínio ou cálcio ou adsorvido nas partículas de argila (ESTEVES, 1988). 
Durante o período de estudo, apesar do fluxo no canal de macrófitas ser superficial, pode-se dizer que a água residuária teve oportunidade de entrar em contato com o solo, uma vez que o tempo de retenção hidráulica que foi maior do que 30 dias.

Acredita-se que a precipitação com hidróxido de ferro e carbonato de cálcio, a adsorção aos minerais de argila do sedimento e a formação de complexos com a matéria orgânica (ESTEVES, 1988; REED, CRITES \& MIDDLEBROOKS, 1995) tenham sido responsáveis pela remoção do fósforo total. No entanto, é justo considerar também para este estudo, a remoção de fósforo por absorção e assimilação pelas macrófitas e microbiota (na fase de crescimento).

Em fevereiro de 2004, o acréscimo de fósforo total na água, que ocorreu após a passagem pelos solos filtrantes, pode estar relacionado com a lixiviação do fósforo presente do sedimento (difusão do P no solo quando a coluna d’água apresenta uma concentração menor) (REDDY \& D'ANGELO, 1994). Já para o ano de 2005, esse acréscimo pode estar relacionado à uma possível condição de anaerobiose do solo, impedindo assim a remoção por precipitados de hidróxido de ferro hidratado; ao aumento da concentração de fósforo no tecido das plantas (limitando a assimilação) somados aos ritmos diários de excreção e a desadsorção do fosfato precipitado com hidróxido de ferro (presença de sulfeto).

Outros fatores que podem ter contribuído também com a concentração encontrada no sistema são: o fluxo de retorno do fósforo com a decomposição da matéria orgânica sedimentada, a morte e decomposição das macrófitas e microbiota e a ressuspensão com o possível revolvimento do solo (ESTEVES, 1988; REDDY \& D'ANGELO, 1994; WATSON et al., 1989).

Apesar da absorção pelas macrófitas e microbiota ser uma ação de remoção rápida, é também um mecanismo reversível, uma vez que o ciclo através do crescimento, morte e decomposição faz retornar a maioria do que foi assimilado via lixiviação. No entanto, segundo Kadlec e colaboradores (2000), essa é uma contribuição residual importante, em longo prazo, para a eficiência dos alagados, uma vez que há o acréscimo de um novo sedimento e, desta forma, de novos sítios de adsorção.

A taxa de remoção total do sistema foi de 51\% em 2004 e de $68 \%$ em 2005. Outros autores estudando sistemas de alagados construídos também observaram remoções significativas do fósforo total da água. Salati e colabores (1999) reportaram uma taxa de remoção de $95 \%$ das águas do Rio Cotia após a passagem por uma estação combinada de alagados construídos com canal de macrófitas e solos filtrantes. 
Watson e demais autores (1989) pesquisaram e agruparam os resultados de eficiência dos sistemas de alagados construídos, da América do Norte e da Europa, na remoção das variáveis de efluentes domésticos de pequenos municípios. Para a variável fósforo total, as taxas de remoção variaram de 12 a 91\%.

Netter (1993) e outros autores, e os pesquisadores Phillipi e Costa (1998) em seus estudos com águas de esgoto, tratadas primariamente com tanque séptico, observaram taxas de remoção superiores a 97\% e 69\% do fósforo total, respectivamente, após a passagem por alagados construídos.

Elias (2003) também observou um grande aporte de fósforo após a passagem da água pelos solos filtrantes. $\mathrm{O}$ autor considerou que as adubações feitas no solo para o plantio e crescimento do arroz, e a própria natureza físico-química do solo podem ter sido responsáveis por esse acréscimo. No entanto, um outro estudo composto por um sistema de canal macrófitas emergentes de fluxo subsuperficial vertical (quatro canais), foi utilizado para tratamento secundário de efluentes domésticos de uma vila na Áustria, e obteve, durante cinco anos de operação, uma taxa média de remoção de $71 \%$ (KADLEC et al., 2000).

Durante todo o período de estudo de 2004 e 2005, os dados obtidos no ponto de entrada do sistema apresentaram valores acima do estabelecido pela Resolução CONAMA 357/2005 para águas doces classe 2 (BRASIL, 2005). No entanto, após a passagem pelo sistema combinado de alagados construídos, todo o efluente analisado (exceto fev/04) apresentou concentrações abaixo de $0,05 \mathrm{mg} \cdot \mathrm{L}^{-1}$.

\subsubsection{Nitrogênio Albuminóide}

A variação dos valores de nitrogênio albuminóide da água em cada um dos pontos de coleta em 2004 está representada na Figura 46.

Observou-se que, em todos os meses de coleta, a concentração de nitrogênio albuminóide na água reduziu após a passagem pelo sistema de alagados construídos.

Os valores obtidos na entrada do alagado (P1) variaram entre $1,03 \mathrm{mg} . \mathrm{L}^{-1}$ (jun) e 2,28mg. $\mathrm{L}^{-1}$ (jul), no ponto 2 , entre $0,79 \mathrm{mg} \cdot \mathrm{L}^{-1}$ (jun) e $1,15 \mathrm{mg} \cdot \mathrm{L}^{-1}$ (fev) e, na saída do sistema (P3), permaneceu na faixa de $0,52 \mathrm{mg} \cdot \mathrm{L}^{-1}$ (jun) a $0,98 \mathrm{mg} \cdot \mathrm{L}^{-1}$ (fev). 


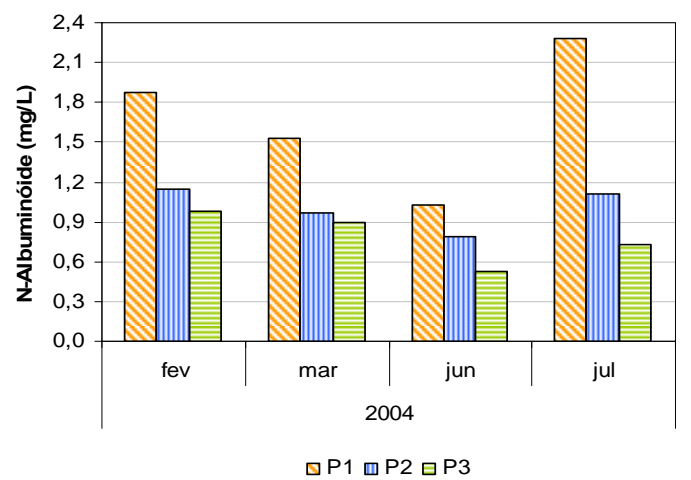

Figura 46: Variação dos valores de nitrogênio albuminóide da água durante o período de coleta de 2004 nas etapas do sistema de alagados construídos.

Os resultados obtidos com a análise estatística SAS e Teste de Tukey podem ser observados na tabela 23. Letras distintas indicam diferenças significativas pelo Teste de Tukey a $5 \%(\mathrm{p} \leq 0,05)$.

Tabela 23: Resultado do Teste de Tukey para a variável nitrogênio albuminóide

\begin{tabular}{cc}
\hline Pontos & $\begin{array}{c}\text { Média (mg.L } \\
\text { 2004 }\end{array}$ \\
\hline 1 & $1,68 \mathrm{a}$ \\
2 & $1,00 \mathrm{ab}$ \\
3 & $0,78 \mathrm{~b}$ \\
\hline
\end{tabular}

Durante o período de estudo em 2004, com um nível de significância de 5\%, observou-se uma remoção significativa de nitrogênio albuminóide após a passagem pelo sistema (P1 é significativamente diferente de P3). A maior média de nitrogênio albuminóide foi encontrada no P1 (1,68mg. $\left.\mathrm{L}^{-1}\right)$ e a menor em P3 $\left(0,78 \mathrm{mg} \cdot \mathrm{L}^{-1}\right)$.

As eficiências de remoção parcial e a total de nitrogênio albuminóide da água, durante o período de estudo em 2004, podem ser visualizadas na figura 47.

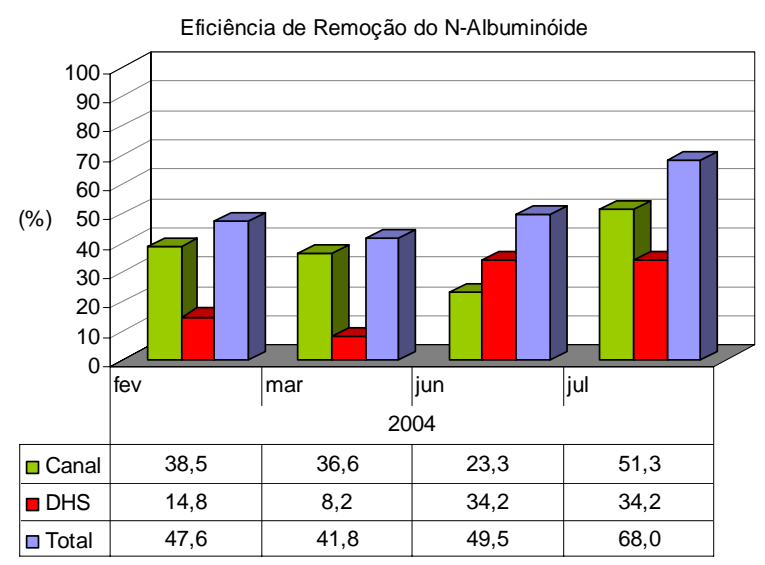

Figura 47: Eficiência total e de cada uma das etapas do sistema de alagados construídos na remoção de nitrogênio albuminóide durante o período de coleta de 2004. 
O conjunto de canais apresentou uma taxa positiva de remoção durante o período de estudo, com uma eficiência que variou entre 23,3\% (jun) e 51,3\% (jul).

Os solos filtrantes também se mostraram eficientes em todo o período de coleta, com uma taxa de remoção de $8,2 \%$ (mar) a 34,2\% (jun/jul).

A eficiência de remoção total do sistema combinado de alagados construídos variou de $41,8 \%$ (mar) a $68 \%$ (jul).

Nitrogênio albuminóide é a medida do nitrogênio orgânico (dissolvido e em suspensão) no corpo d água, e é resultante da degradação das proteínas. Sua remoção no sistema se dá pela transformação em nitrogênio amoniacal (hidrólise ou degradação microbiana) e depois pelos processos de nitrificação e desnitrificação (ESTEVES, 1988; KADLEC et al., 2000).

A taxa de remoção média do sistema durante o período de 2004 foi de $51,7 \%$. Kadlec e Knight (1996), em uma pesquisa que fizeram sobre a eficiência dos alagados norte-americanos, reportaram uma média de remoção de $46 \%$ do nitrogênio orgânico para sistemas de fluxo superficial e de 60\% para os de fluxo subsuperficial. Thut (1989) verificou uma taxa de remoção média superior a 30\% em canais de macrófitas emergentes durante três anos de estudo.

\subsubsection{Nitrogênio Amoniacal}

Os valores de nitrogênio amoniacal da água obtidos nos pontos de coleta em 2004 e 2005 estão representados na figura 48.

A concentração medida em 2004 na entrada do alagado (P1) variou entre 0,28mg. $\mathrm{L}^{-1}$ (fev) e $1,71 \mathrm{mg} . \mathrm{L}^{-1}$ (jun), entre $0,11 \mathrm{mg} . \mathrm{L}^{-1}$ (mar) e $1,68 \mathrm{mg} . \mathrm{L}^{-1}$ (jul) no ponto 2 e, na saída do sistema (P3), entre $0,12 \mathrm{mg} . \mathrm{L}^{-1}$ (fev/mar) e $0,90 \mathrm{mg} \cdot \mathrm{L}^{-1}$ (jul).

Em 2005, a concentração de fósforo total no P1 variou entre $0,10 \mathrm{mg} \cdot \mathrm{L}^{-1}$ (abr) e 2,35mg. $\mathrm{L}^{-1}$ (ago), maior valor encontrado durante todo o trabalho. Nas amostras coletadas no ponto 2 , os valores variaram de $0,16 \mathrm{mg} . \mathrm{L}^{-1}$ (mar/ago) a $1,24 \mathrm{mg} . \mathrm{L}^{-1}$ (jul) e no ponto 3 , de $0,04 \mathrm{mg} . \mathrm{L}^{-1}$ (jul) a $0,46 \mathrm{mg} . \mathrm{L}^{-1}$ (abr). 


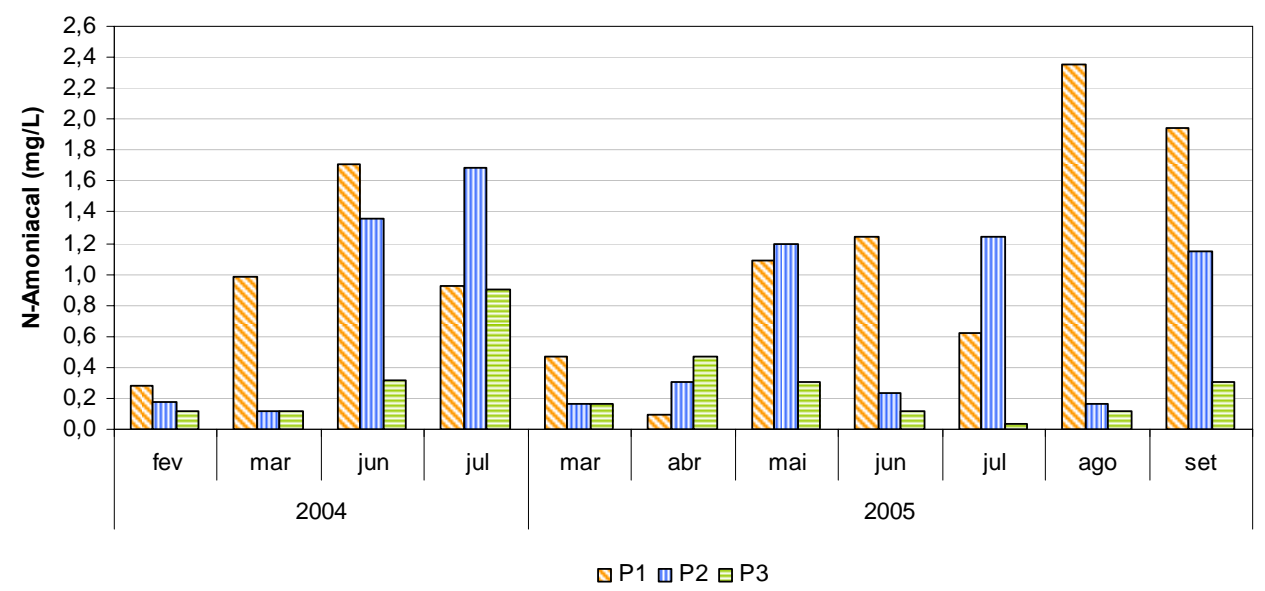

Figura 48: Variação dos valores de nitrogênio amoniacal da água durante o período de coleta de 2004 e 2005 nas etapas do sistema de alagados construídos.

Os resultados obtidos com a análise estatística SAS e Teste de Tukey podem ser observados na tabela 24. Letras distintas indicam diferenças significativas pelo Teste de Tukey a $5 \%(\mathrm{p} \leq 0,05)$.

Tabela 24: Resultado do Teste de Tukey para a variável nitrogênio amoniacal.

\begin{tabular}{ccc}
\hline \multirow{2}{*}{ Pontos } & \multicolumn{2}{c}{ Média (mg. $\mathbf{L}^{\mathbf{- 1}}$ ) } \\
& $\mathbf{2 0 0 4}$ & $\mathbf{2 0 0 5}$ \\
\hline 1 & $0,97 \mathrm{a}$ & $1,12 \mathrm{X}$ \\
2 & $0,83 \mathrm{a}$ & $0,63 \mathrm{XY}$ \\
3 & $0,36 \mathrm{a}$ & $0,22 \mathrm{Y}$ \\
\hline
\end{tabular}

De acordo com o resultado do teste, as concentrações médias de nitrogênio amoniacal encontradas, em cada um dos pontos de coleta em 2004, não são diferentes significativamente. $\mathrm{O}$ teste de Tukey trabalha com a comparação das médias e por isso não conseguiu demonstrar estatisticamente alterações bruscas de valores mensais. $\mathrm{O}$ mês de fevereiro pode ser considerado como o único a não apresentar concentrações significativamente diferentes ao longo do sistema. Na coleta de março e de junho, observou-se uma remoção significativa de mais de $80 \%$ da variável, já no mês de julho de 2004, o acréscimo foi de mais de $80 \%$ após a passagem pelo sistema de canais. Por isso, aceita-se que houve uma remoção significativa da concentração de nitrogênio amoniacal após a passagem pela estação de tratamento, assim como um acréscimo após a passagem pelo sistema de canais.

Para o ano de 2005 pode-se afirmar, com um nível de 5\% de significância, que houve uma remoção significativa da concentração de nitrogênio amoniacal após a 
passagem pelo sistema combinado de alagados construídos. A maior média encontrada em 2005 foi no ponto $1\left(1,12 \mathrm{mg} \cdot \mathrm{L}^{-1}\right)$ e a menor no ponto $3\left(0,22 \mathrm{mg} \cdot \mathrm{L}^{-1}\right)$.

As eficiências de remoção parcial e a total de nitrogênio amoniacal da água, durante o período de estudo em 2004 e 2005, podem ser visualizadas na figura 49.

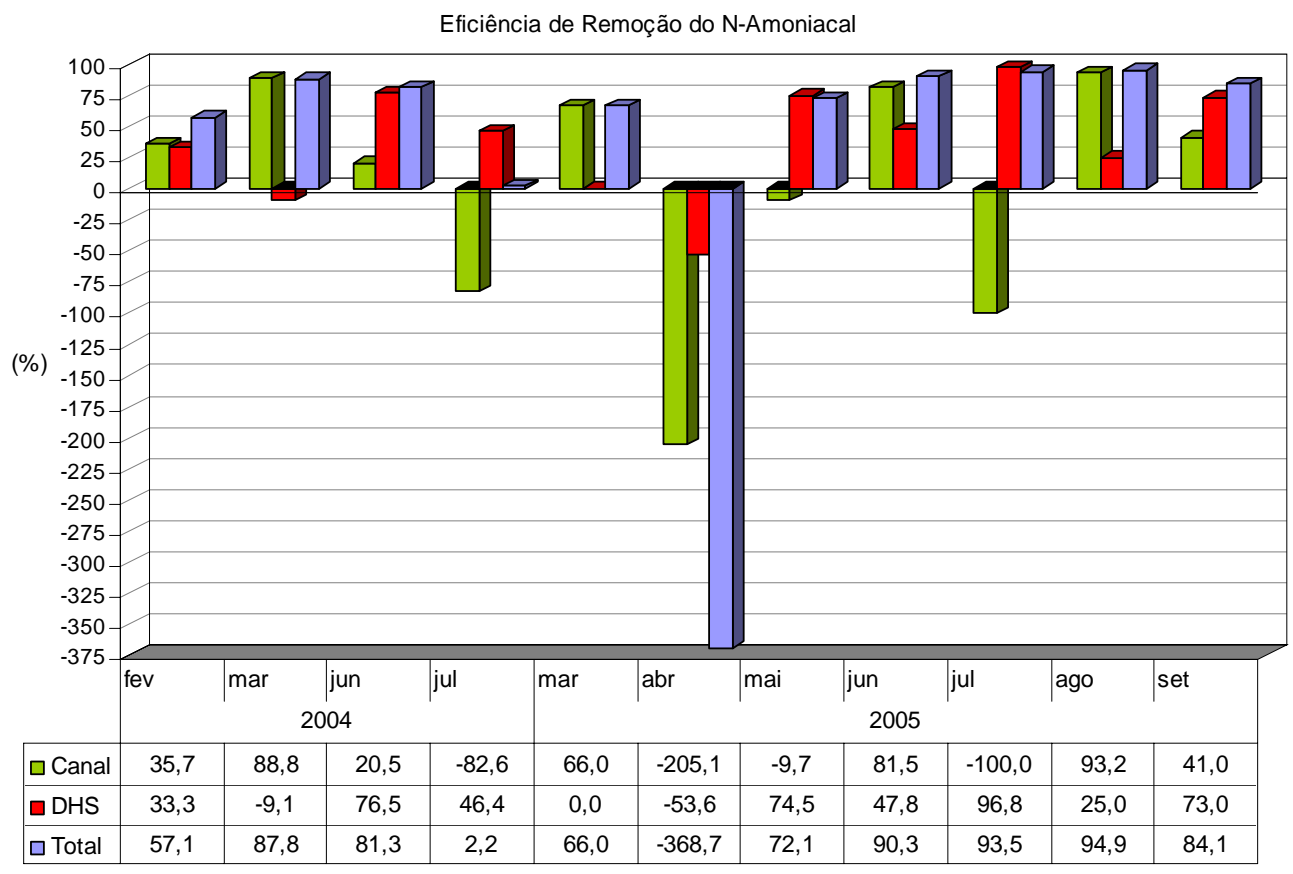

Figura 49: Eficiência total e de cada uma das etapas do sistema de alagados construídos na remoção de nitrogênio amoniacal durante o período de coleta de 2004 e 2005.

Os canais apresentaram, em sua maioria, uma taxa de remoção positiva que variou entre 20,5\% (jun/04) a 93,2\% (ago/05). No entanto, foi observado um acréscimo da concentração amoniacal nos meses de julho de 2004, abril, maio e julho de 2005 após a passagem pelos canais. A taxa de acréscimo variou de 9,7\% (mai/04) a 205,1\% $(\mathrm{abr} / 05)$.

Com relação aos solos filtrantes, a eficiência de remoção variou entre $25 \%$ (ago/04) e 96,8\% (jul/05). Entretanto, no mês de março de 2004 e abril de 2005, foi observado um acréscimo de $9,1 \%$ e 53,6\% respectivamente, do valor da concentração de nitrogênio amoniacal.

O sistema combinado de alagados construídos mostrou-se eficiente, com uma taxa de remoção que variou entre 57,1\% (fev/04) e 94,9\% (ago/05). No entanto, na coleta do mês de julho de 2004, observou-se uma pequena porcentagem de remoção 
(2,2\%) e na coleta do mês de abril de 2005 , um acréscimo $(368,7 \%)$ da concentração após a passagem pela estação.

A remoção do nitrogênio amoniacal pode ser atribuída ao processo de nitrificação (aeróbio) seguido da desnitrificação (anaeróbio), a absorção e assimilação pelas macrófitas e microbiota, e a adsorção (troca iônica) as partículas do solo (REDDY \& D'ANGELO, 1994). A remoção por volatilização, no entanto, é considerada por Reddy e Patrick ${ }^{18}$ (1984) apud Kadlec e colaboradores (2000) como sendo insignificante em alagados com $\mathrm{pH}$ abaixo de 9,3.

O acréscimo observado nas etapas do sistema pode ser resultante tanto da mineralização da matéria orgânica proveniente do efluente de entrada quanto da decomposição das plantas que não se adaptaram em 2004. Uma baixa taxa de nitrificação nos canais também pode ter contribuído com a concentração encontrada, uma vez que as bactérias nitrificantes são organismos sensíveis e extremante susceptíveis a uma grande variedade de inibidores, incluindo altas concentrações de nitrogênio amoniacal (COOPER ${ }^{19}$ et al., 1996 apud KADLEC et al., 2000).

O nitrogênio amoniacal, assim como já citado para o fósforo, também pode ter sido liberado do solo para a coluna d’água em resposta ao gradiente de concentração (REDDY \& D'ANGELO, 1994).

Em 2005, a alta concentração da variável no canal de decantação e de macrófitas pode ter sido conseqüência dos fatores já citados para 2004 e também a possível baixa concentração de oxigênio presente, devido à barreira exercida pelas macrófitas (ocupam toda a superfície do canal de MAFE) para difusão de oxigênio (interface ar/água). O transporte de oxigênio realizado pelas plantas através do aerênquima e das raízes não é suficiente para satisfazer a demanda utilizada pelas bactérias heterotróficas resultando, desta forma, em condições de anaerobiose e limitando o processo de nitrificação da amônia (BRIX, 1993). Segundo Bitton ${ }^{20}$ (1994) apud Kyambadde e colaboradores (2005), as bactérias nitrificantes têm menos afinidade por oxigênio do que as bactérias heterotróficas aeróbias e por isso, na competição por oxigênio, elas são desfavorecidas.

\footnotetext{
18 REDDY, K.R; PATRICK, W.H. (1984) Nitrogen transformation and loss in flooded soil and sediments. CRC. Crit. Rev. Envir. Control. v.13, p.273-309.

${ }^{19}$ COOPER et al. (1996). Reed beds and constructed wetlands for wastewater treatment. Medmenham, Marlow: Wrc Publication.

${ }^{20}$ BITTON, G. (1994). Wastewater Microbiology, Wiley-Liss, New York.
} 
Com relação ao funcionamento do sistema, um acréscimo da concentração de nitrogênio amoniacal, só foi observado na coleta de abril de 2005, devido ao desempenho negativo tanto do conjunto de canais quanto dos solos filtrantes. A baixa concentração de nitrogênio amoniacal presente no efluente de entrada pode também, segundo Kadlec e Knight (1996), resultar em uma queda da eficiência de remoção ou em uma remoção negativa do sistema, uma vez que a produção interna de amônia (amonificação), a excreção e a liberação pelo solo acaba sendo maior do que a assimilação, adsorção e nitrificação. Em abril de 2005 a concentração de nitrogênio amoniacal no ponto de entrada do sistema foi $0,1 \mathrm{mg} / \mathrm{L}$, a menor encontrada durante todo o período de estudo.

Segundo Reed e colaboradores (1995), o potencial de remoção de nitrogênio pode levar alguns anos para se estabilizar, uma vez que requer mais de uma estação de crescimento das plantas, com desenvolvimento completo do sistema de raízes, a criação e uma nova camada de solo (litter) e o estabelecimento da microbiota e dos organismos bentônicos.

A eficiência total do sistema foi de 57,1\% em 2004 e de 83,5\% em 2005 (sem o mês de abril). No pré-tratamento das águas do Rio Cotia, uma taxa de remoção total de 88\% foi observada após a passagem pelo sistema de alagados (SALATI et al., 1999).

Gersberg e colaboradores (1989), Netter (1993) e os pesquisadores Steiner e Combs (1993) observaram, respectivamente, taxas de remoção na faixa de 28 a 78\%, de 71 a $97 \%$ e de $44 \%$ do nitrogênio amoniacal de efluentes domésticos primariamente tratados com tanque séptico após a estação de alagados.

O tratamento secundário de efluentes domésticos com wetlands na Áustria obteve uma taxa média de remoção de $99 \%$ de nitrogênio amoniacal em cinco anos de monitoramento (KADLEC et al., 2000). Estes mesmos autores, em um estudo sobre as eficiências de remoção nos sistemas norte americanos, observaram uma taxa média de remoção de 54\% em sistemas de fluxo superficial.

Elias (2003) obteve uma taxa de redução mínima de 61,5\% (verão) e máxima de 92,8\% (primavera) nos alagados construídos de Analândia e Nogueira (2003) reportou taxas de 32\% em Piracicaba. Cecconello (2005) observou no seu estudo uma remoção que variou de 28 a $87,1 \%$ da concentração amoniacal do chorume.

Valentim (2003) verificou, durante seus estudos, que grande parte dos valores de nitrogênio amoniacal encontrado no efluente dos alagados superou os do afluente, taxa de acréscimo de 4 a $73 \%$. O autor considerou que isto tenha sido resultado da hidrólise 
do material particulado retido formando amônia e a insuficiência de oxigênio liberado pelas raízes das macrófitas para oxidá-la.

Durante os anos de 2004 e 2005, todos os pontos de coleta apresentaram uma concentração de nitrogênio amoniacal que atende o limite estabelecido pela Resolução CONAMA 357/2005 para águas doces classe 2 (BRASIL, 2005). Os valores encontrados ficaram abaixo de $3,7 \mathrm{mg} \cdot \mathrm{L}^{-1}(\mathrm{pH} \leq 7,5)$ e de $2,0 \mathrm{mg} \cdot \mathrm{L}^{-1}(7,5<\mathrm{pH}<8,0)$.

\subsubsection{Nitrato e Nitrito}

As concentrações de nitrato e nitrito na água durante o período de estudo em 2004 ficaram, em sua maioria, abaixo do limite de quantificação do método utilizado, não sendo possível realizar a análise estatística.

Os valores da concentração de nitrato e nitrito nas etapas do sistema podem ser visualizados nas tabelas 25 e 26 respectivamente.

Tabela 25: Variação dos valores de nitrato na água durante o período de coleta de 2004 nas etapas do sistema de alagados construídos.

\begin{tabular}{ccccc}
\hline & \multicolumn{4}{c}{ Nitrato (mg/L) } \\
& fev & mar & jun & jul \\
\hline P1 & $<0,1$ & $<0,1$ & 0,15 & $<0,1$ \\
P2 & $<0,1$ & $<0,1$ & $<0,1$ & $<0,1$ \\
P3 & $<0,1$ & $<0,1$ & $<0,1$ & $<0,1$ \\
\hline
\end{tabular}

Tabela 26: Variação dos valores de nitrito na água durante o período de coleta de 2004 nas etapas do sistema de alagados construídos.

\begin{tabular}{ccccc}
\hline & \multicolumn{4}{c}{ Nitrito (mg/L) } \\
& fev & mar & jun & jul \\
\hline P1 & $<0,001$ & 0,003 & 0,012 & 0,004 \\
P2 & $<0,001$ & $<0,001$ & $<0,001$ & $<0,001$ \\
P3 & $<0,001$ & $<0,001$ & $<0,001$ & $<0,001$ \\
\hline
\end{tabular}

Como a maioria dos valores encontrados está abaixo do limite de quantificação do método, pôde-se calcular somente a taxa de remoção do conjunto de canais e de remoção total do sistema de alagados construídos. Os valores encontrados no P2 e no P3 são numericamente similares, e por isso, a taxa de remoção total do sistema pode ser considerada como sendo igual à taxa de remoção do canal de decantação e de macrófitas (Fig.50). 


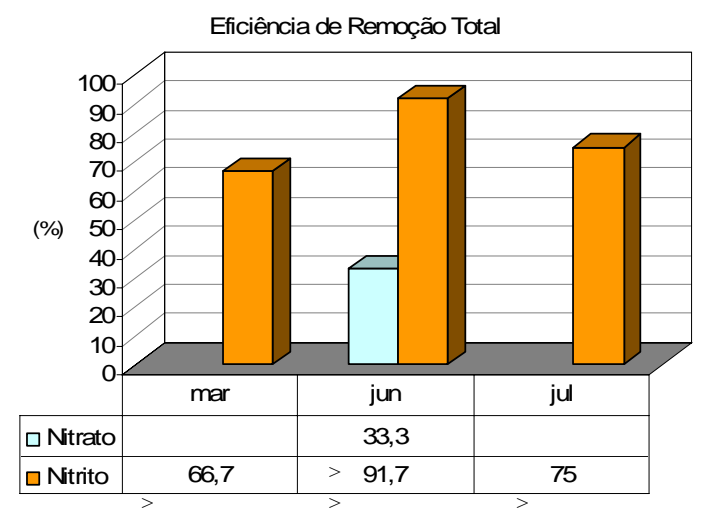

Figura 50: Eficiência total do sistema de alagados construídos na remoção de nitrato e nitrito durante o período de coleta de 2004.

Após a passagem pelo sistema de alagados construídos, verificou-se uma taxa de remoção de nitrato positiva para o mês de junho (>33,3\%). Com relação ao nitrito, também foi verificada uma eficiência de remoção positiva, superior a $66,7 \%$.

O nitrato é removido nos sistemas pela absorção por macrófitas e microbiota e pelo processo de desnitrificação. A baixa concentração de nitrato medida no sistema pode ser explicada pela rapidez com que esses elementos, ao serem formados, são utilizados como aceptores de elétrons em ambientes anaeróbios ou por não terem sido formados em virtude da insuficiência de oxigenação no meio e pela presença de condições inibidoras às bactérias nitrificantes.

Para se explicar a remoção no canal de macrófitas em junho, sugere-se duas hipóteses: a absorção pelas macrófitas (estação de crescimento) e a presença de zonas anaeróbias próximas ao sedimento, favorecendo a desnitrificação.

Valentim (2003) verificou uma baixa capacidade de desnitrificação em alagados de fluxo subsuperficial. No entanto, outros autores trabalhando com tratamento de águas residuárias com concentrações maiores de nitrato verificaram taxas de remoção superiores a 70\% (HUETT et al., 2005; SALATI et al., 1999).

Elias (2003), no tratamento das águas do Rio Retiro, obteve uma eficiência de remoção que variou de 60\% (outono) a 100\% (verão). Jucá (2003) e Cecconello (2005), no tratamento secundário do chorume, observaram uma remoção superior a 16\%.

O nitrito, por sua vez, devido a sua condição energética intermediária, não se apresenta quimicamente estável na maioria dos sistemas de alagados construídos, e é geralmente encontrado em taxas muito baixas (KADLEC, 1997).

Quando o nitrito foi encontrado em concentrações maiores no efluente bruto, o sistema de alagados mostrou-se eficiente em sua remoção. As águas do Rio Retiro 
(ELIAS, 2003) tiveram uma remoção que variou de 47,2\% (inverno) a 90,5\% (primavera) e as do Rio Cotia (SALATI et al., 1999), uma eficiência de remoção de 99\% do nitrito após a passagem pelos alagados construídos. No tratamento de percolados de aterro sanitário, Jucá (2003) alcançou eficiências de remoção de 26,1\%.

Durante o período de estudo, todos os pontos de coleta apresentaram concentrações de nitrato e nitrito que atendem o limite estabelecido pela Resolução CONAMA 357/2005 para águas doces classe 2 (BRASIL, 2005). Os valores encontrados foram menores que $10 \mathrm{mg} . \mathrm{L}^{-1}$ para nitrato e menores que $1 \mathrm{mg} . \mathrm{L}^{-1}$ para nitrito.

\subsubsection{Metais}

\subsubsection{Cádmio}

Os valores de cádmio da água obtidos nos pontos de coleta em 2004 estão representados na figura 51.

A concentração medida em 2004 na entrada do alagado (P1) variou entre $<0,0005 \mathrm{mg}$. $\mathrm{L}^{-1}$ (fev) e $0,0012 \mathrm{mg} . \mathrm{L}^{-1}$ (jul); no ponto 2 , entre $0,0006 \mathrm{mg} . \mathrm{L}^{-1}$ (fev) e 0,001 (jul) e, na saída do sistema (P3), entre $<0,0005 \mathrm{mg} \cdot \mathrm{L}^{-1}$ (fev) e $0,0008 \mathrm{mg} \cdot \mathrm{L}^{-1}$ (jun).

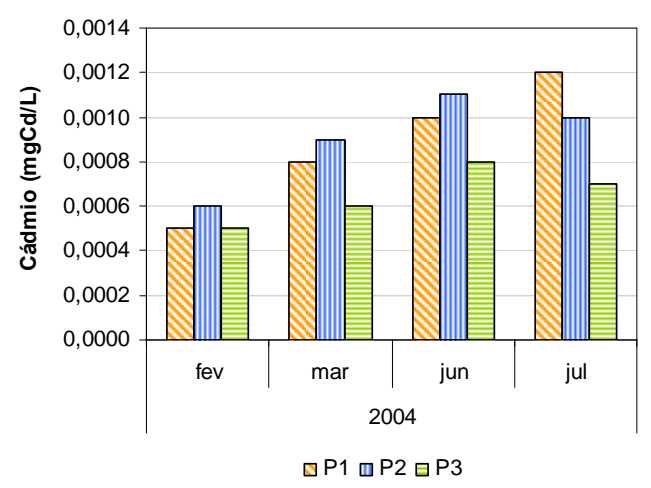

Figura 51: Variação dos valores de cádmio da água durante o período de coleta de 2004 nas etapas do sistema de alagados construídos.

Os resultados obtidos com a análise estatística SAS e Teste de Tukey podem ser observados na tabela 27. Letras distintas indicam diferenças significativas pelo Teste de Tukey a $5 \%(\mathrm{p} \leq 0,05)$. 
Tabela 27: Resultado do Teste de Tukey para a variável cádmio.

\begin{tabular}{cc}
\hline Pontos & $\begin{array}{c}\text { Média (mg.L } \mathbf{L}^{-1} \text { ) } \\
\mathbf{2 0 0 4}\end{array}$ \\
\hline 1 & $0,0008 \mathrm{a}$ \\
2 & $0,0009 \mathrm{a}$ \\
3 & $0,0005 \mathrm{a}$ \\
\hline
\end{tabular}

De acordo com os valores médios de cádmio, a concentração do metal aumentou após a passagem pelos canais e reduziu após os solos filtrantes, no entanto, segundo o teste realizado, não há diferença significativa entre eles.

As eficiências de remoção parcial e a total de cádmio da água, durante o período de estudo em 2004, podem ser visualizadas na figura 52.

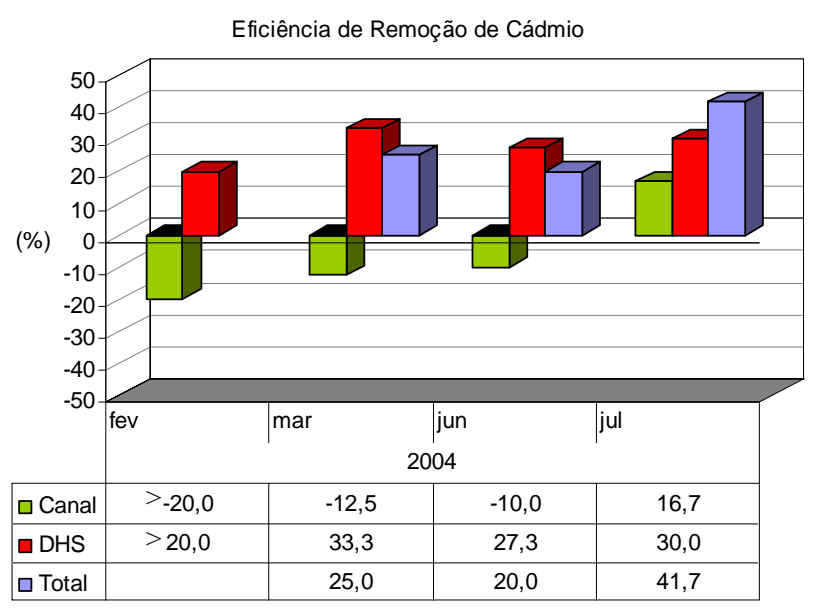

Figura 52: Eficiência total e de cada uma das etapas do sistema de alagados construídos na remoção de cádmio durante o período de coleta de 2004. Como o valor encontrado em P1 e P3 está abaixo do limite de quantificação não foi possível calcular a taxa de remoção total em fevereiro.

Os canais de decantação e de macrófitas apresentaram um desempenho positivo de remoção somente na coleta do mês de julho, com uma eficiência de 16,7\%. Nos demais meses ocorreu um acréscimo superior a $10 \%$ do valor encontrado no efluente bruto.

Com relação aos solos filtrantes, verificou-se um desempenho positivo de remoção em todas as coletas, a eficiência encontrada foi superior a $20 \%$.

O sistema combinado de alagados construídos apresentou uma taxa de remoção de cádmio que variou entre $20 \%$ (jun) e $41,7 \%$ (jul). No mês de fevereiro, o valor medido na entrada e saída do sistema de alagados construídos foi menor que $2 \mathrm{mgCd} / \mathrm{L}$, devido ao limite de quantificação e por isso não há como afirmar se a concentração aumentou ou reduziu. 
O cádmio pode ser removido do sistema através dos processos de adsorção às plantas e microrganismos, formação de complexos com a matéria orgânica e precipitação na forma de hidróxidos e sulfetos (anaerobiose) e co-precipitação com hidróxidos de ferro e manganês e carbonatos de cálcio (KADLEC et al., 2000; LEITÃO et al., 2006; VYMAZAL, 1998). A assimilação pelas macrófitas também pode acontecer. Obarska-Pempkowiak (2000) em seu trabalho com tratamento de secundário de esgoto doméstico, observou uma acumulação de 14,8\% do cádmio na biomassa dos macrófitas emergentes (juncos).

O aumento da concentração após a passagem pelos canais pode estar relacionado ao processo de desadsorção destes metais com a competição com os demais íons nos sítios de troca catiônica, e a quebra dos complexos formados com a matéria orgânica e partículas de argila, e possivelmente ao cádmio liberado pela decomposição das macrófitas.

A eficiência de remoção obtida após a passagem pelo sistema foi de $28,9 \%$. Salati e colaboradores (1999) observaram um aumento da concentração de cádmio (26,7\%) nas águas do Rio Cotia após a passagem pelo canal de macrófitas e solos filtrantes com tempo de retenção hidráulico de 5 dias. No entanto, em um outro estudo com tempo de retenção de 2,5 dias, foi observada uma taxa de remoção de $20,7 \%$ devido à eficiência dos solos, já que ocorreu um acréscimo após a passagem pelo canal de macrófitas flutuantes.

O sistema utilizado por Obarska-Pempkowiak (2000), um canal de macrófitas emergentes de fluxo superficial seguido por dois canais de fluxo vertical (ascendente e descendente), para tratamento secundário apresentou uma taxa de remoção de 92,3\%. Segundo o autor, a maior remoção ocorreu nos sistemas de fluxo vertical pelo mecanismo de adsorção.

O monitoramento de uma área alagada construída para remoção de percolados de aterro sanitário em Minnesota (EUA) apresentou dados de remoção de $65 \%$ do cádmio (KADLEC et al., 2000). Cheng e demais autores (2002), utilizando um sistema composto por duas células de fluxo vertical (descendente e ascendente), alcançaram eficiências de $100 \%$ de remoção de cádmio durante 5 meses de operação.

Durante o período de estudo, o efluente de saída do sistema apresentou concentrações de cádmio que atenderam a Resolução CONAMA 357/2005 para águas doces classe 2 (BRASIL, 2005), apresentado valores abaixo de $0,001 \mathrm{mg} \cdot \mathrm{L}^{-1}$. 


\subsubsection{Chumbo}

A variação da concentração de chumbo na água em cada um dos pontos de coleta de 2004 está representada na Figura 53.

Como nos meses de fevereiro e março, a concentração encontrada em todos os pontos de coleta ficou abaixo do limite de quantificação $\left(<0,005 \mathrm{mg} . \mathrm{L}^{-1}\right)$, não foi possível representá-los no gráfico.

Considerando somente os meses de junho e julho, os valores obtidos, na entrada do alagado (P1) foram 0,0062mg. $\mathrm{L}^{-1}$ (junho) e $0,015 \mathrm{mg} \cdot \mathrm{L}^{-1}$ (jul), no ponto 2 foram 0,0096mg. $\mathrm{L}^{-1}$ (jun) e 0,0180mg. $\mathrm{L}^{-1}$ (jul) e, na saída do sistema (P3), 0,0058mg.L $\mathrm{L}^{-1}$ (jun) e $0,0150 \mathrm{mg} \cdot \mathrm{L}^{-1}(\mathrm{jul})$.

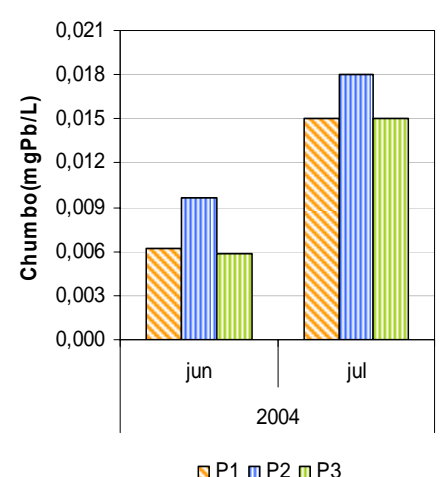

Figura 53: Variação dos valores de chumbo da água durante o período de coleta de 2004 nas etapas do sistema de alagados construídos.

Os resultados obtidos com a análise estatística SAS e Teste de Tukey podem ser observados na tabela 28. Letras distintas indicam diferenças significativas pelo Teste de Tukey a $5 \%(\mathrm{p} \leq 0,05)$.

Tabela 28: Resultado do Teste de Tukey para a variável chumbo

\begin{tabular}{cc}
\hline Pontos & $\begin{array}{c}\text { Média (mg.L } \\
\text { 2004 }\end{array}$ \\
\hline 1 & $0,0106 \mathrm{a}$ \\
2 & $0,0138 \mathrm{a}$ \\
3 & $0,0104 \mathrm{a}$ \\
\hline
\end{tabular}

Observou-se que, nos meses de coleta (junho e julho de 2004), a concentração média de chumbo na saída do canal de macrófitas (P2) foi a mais alta enquanto que a do ponto de saída (P3) foi a mais baixa. No entanto, segundo o teste realizado, não há diferença significativa entre os pontos. 
As eficiências de remoção parcial e a total de chumbo da água, durante o período de estudo em 2004, podem ser visualizadas na figura 54.

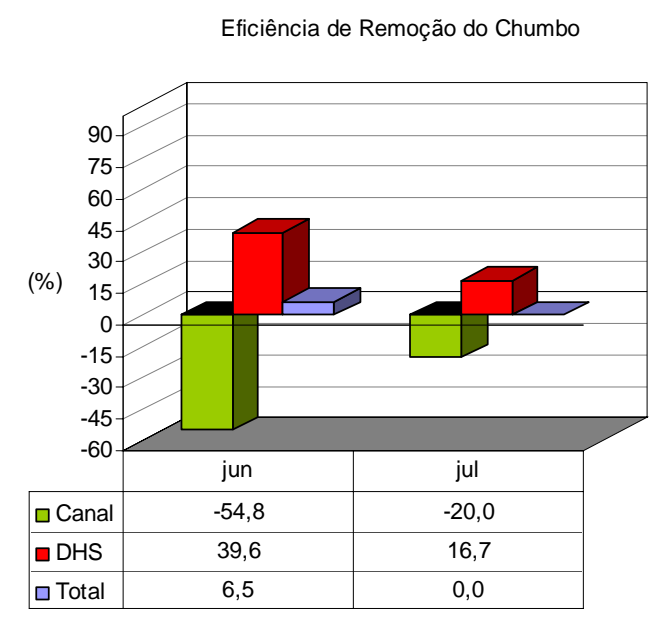

Figura 54: Eficiência total e de cada uma das etapas do sistema de alagados construídos na remoção de chumbo durante o período de coleta de 2004.

Após a passagem pelos canais, foi observado um aumento da concentração de chumbo na água. A taxa de acréscimo foi de 58,4\% em junho e $20 \%$ em julho.

Com relação aos solos filtrantes, uma porcentagem de remoção positiva em junho $(39,6 \%)$ e em julho $(16,7 \%)$ foi verificada.

No entanto, o sistema só se apresentou eficiente na coleta do mês de junho, com uma taxa de remoção de $6,5 \%$. Como são poucos os dados para esta variável, não se pode afirmar com certeza qual o desempenho do sistema.

A remoção do chumbo, assim como já citado para a variável cádmio, ocorre devido aos processos de adsorção, formação de complexos com a matéria orgânica, precipitação na forma de hidróxidos e sulfetos, co-precipitação com hidróxidos de ferro, manganês, carbonato de cálcio e retenção por parte da vegetação dos hidróxidos de metal formados e possível assimilação pela vegetação (VYMAZAL, 1998; KADLEC et al., 2000; OBARSKA-PEMPKOWIAK, 2000).

O aumento da concentração após a passagem pelos canais de macrófitas pode estar relacionado, principalmente, ao processo de desadsorção (competição com os demais íons pelos sítios) e a quebra dos complexos formados com a matéria orgânica e com as partículas de solo.

A eficiência de remoção obtida após a passagem pelo sistema foi de $6,5 \%$. No entanto, outros sistemas têm apresentado eficiências melhores. Meiorin (1989), estudando um sistema de alagados para tratamento de águas residuárias de escoamento 
urbano, obteve uma taxa de remoção que variou de 30 a $83 \%$. A estação de tratamento com alagados construídos utilizada por Obarska-Pempkowiak (2000) apresentou eficiências de $87,8 \%$. Segundo o autor, a maior remoção ocorreu nos sistemas de fluxo vertical pelo mecanismo de adsorção.

Kadlec e colaboradores (2000) observaram uma eficiência média de remoção de $80 \%$ da concentração de chumbo nos percolados do aterro sanitário em Minnesota (EUA). Cheng e demais autores (2002), em cinco meses de operação, alcançaram eficiências de remoção de $100 \%$ durante cinco meses de operação.

O estudo desenvolvido com as águas do Rio Cotia, entretanto, também apresentou acréscimos $(51,7 \%)$ na concentração após a passagem pelos alagados com tempo de residência de cinco dias. Trabalhando com um tempo de retenção menor (dois dias), uma eficiência de remoção total de $15 \%$ foi obtida, no entanto, novamente o conjunto de canais apresentou um desempenho negativo (SALATI et al., 2000).

Durante o período de estudo, somente a coleta de julho não apresentou uma concentração de chumbo que atendesse a Resolução CONAMA 357/2005 para águas doces classe 2 (BRASIL, 2005). Nos outros meses, os valores encontrados ficaram abaixo do limite estabelecido pela resolução de $0,01 \mathrm{mg} \cdot \mathrm{L}^{-1}$.

\subsubsection{Ferro Total}

A variação dos valores de ferro total da água em cada um dos pontos de coleta em 2004 e 2005 está representada na Figura 55.

Somente na coleta do mês de fevereiro, a concentração de ferro total medida na entrada do sistema de alagados (P1) apresentou valores mais altos do que o ponto de saída (P3).

A concentração de ferro total medida na entrada do sistema (P1) variou entre 0,49mg.L $\mathrm{L}^{-1}$ (jun) e $0,89 \mathrm{mg} \cdot \mathrm{L}^{-1}$ (fev), na faixa de $0,31 \mathrm{mg} / \mathrm{L}^{-1}$ (mar) a $0,52 \mathrm{mg} \cdot \mathrm{L}^{-1}$ (jul) no ponto 2 e, na saída do sistema (P3) variou entre $0,21 \mathrm{mg} . \mathrm{L}^{-1}$ (fev) a 2,36mg.L $\mathrm{L}^{-1}$ (mar).

No ano de 2005, os valores em P1 variaram entre $0,36 \mathrm{mg} / \mathrm{L}^{-1}$ (mar) e $0,79 \mathrm{mg} / \mathrm{L}^{-1}$ (mai), no ponto 2 entre $0,41 \mathrm{mg} / \mathrm{L}^{-1}$ (ago) e $3,05 \mathrm{mg} / \mathrm{L}^{-1}$ (mar), e na saída do sistema (P3) ficaram na faixa de $0,68 \mathrm{mg} / \mathrm{L}^{-1}$ (jul) a $2,29 \mathrm{mg} / \mathrm{L}^{-1}$ (abr). 


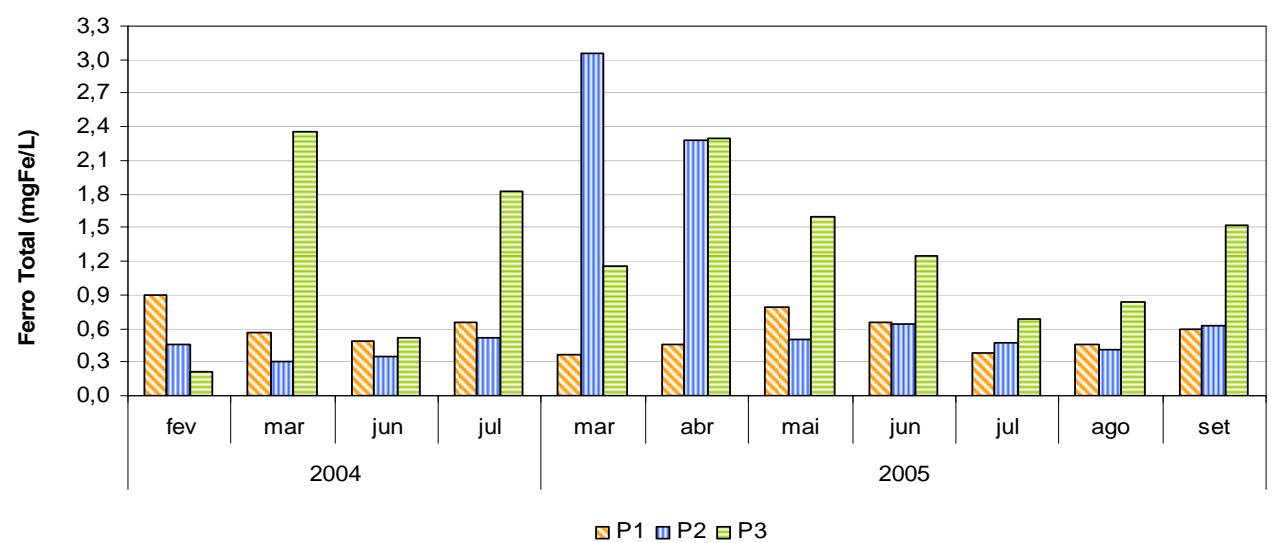

Figura 55: Variação dos valores de ferro total da água durante o período de coleta de 2004 e 2005 nas etapas do sistema de alagados construídos.

Os resultados obtidos com a análise estatística SAS e Teste de Tukey podem ser observados na tabela 29. Letras distintas indicam diferenças significativas pelo Teste de Tukey a $5 \%(\mathrm{p} \leq 0,05)$.

Tabela 29: Resultado do Teste de Tukey para a variável ferro total.

\begin{tabular}{ccc}
\hline \multirow{2}{*}{ Pontos } & \multicolumn{2}{c}{ Média (mg. . $^{-\mathbf{1}}$ ) } \\
& 2004 & 2005 \\
\hline 1 & $0,65 \mathrm{a}$ & $0,53 \mathrm{X}$ \\
2 & $0,41 \mathrm{a}$ & $1,14 \mathrm{X}$ \\
3 & $1,23 \mathrm{a}$ & $1,34 \mathrm{X}$ \\
\hline
\end{tabular}

Durante o ano de 2004, foi observada uma redução na concentração média de ferro total após a passagem pelos canais e um acréscimo após os solos filtrantes. No entanto, em 2005, as duas etapas do sistema apresentaram um desempenho negativo. Todavia não há diferenças significativas entre os pontos de coleta em 2004 e 2005.

Como a concentração de ferro total no sistema é muito baixa, o teste utilizado não foi sensível para o acréscimo observado durante o período de estudo. Por isso, acredita-se que houve um aumento significativo da variável após a passagem pelo sistema de alagados tanto em 2004 quanto em 2005, apresentando um acréscimo médio de mais de $50 \%$.

As eficiências de remoção parcial e a total de ferro total da água, durante o período de estudo em 2004 e 2005, podem ser visualizadas na figura 56. 


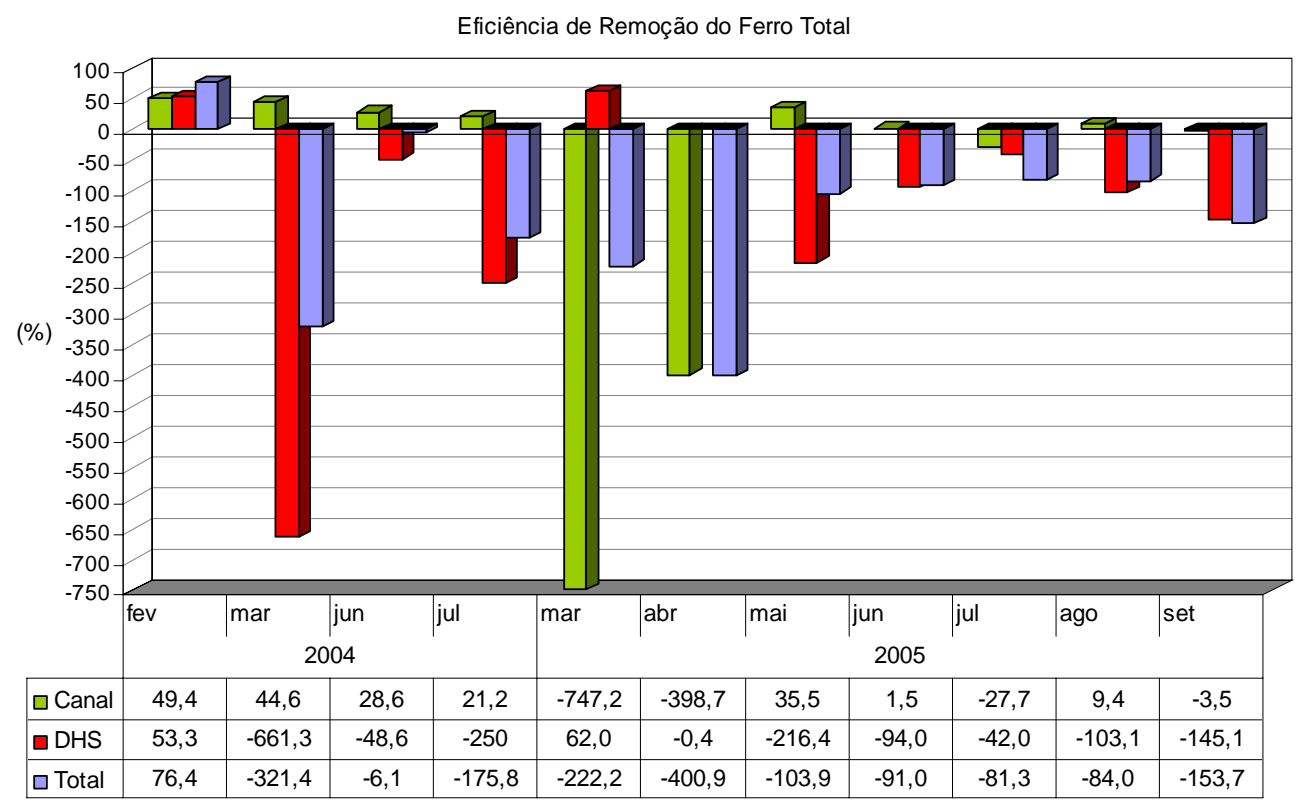

Figura 56: Eficiência total e de cada uma das etapas do sistema de alagados construídos na remoção de ferro total durante o período de coleta de 2004 e 2005.

O canal de decantação e o canal de macrófitas apresentaram, em sua maioria, uma taxa de remoção positiva que variou entre 1,5\% (jun/05) a 49,4\% (fev/05). No entanto, foi observado um acréscimo da concentração de ferro total nos meses de março, abril, julho e setembro de 2005 após a passagem pelos canais. A taxa de acréscimo variou de 3,5\% (set/05) a 747,2\% (mar/05).

Com relação aos solos filtrantes, a eficiência de remoção foi negativa para a maioria dos meses de coleta. Observou-se um acréscimo da concentração de ferro total após a passagem pelo sistema DHS que variou entre 42\% (jul/05) e 661,3\% (mar/04). Entretanto, no mês de fevereiro de 2004 e março de 2005, foi observada uma taxa positiva de remoção de $53,3 \%$ e $62 \%$ respectivamente. Na coleta do mês de abril, a variação da concentração foi quase nula.

O sistema combinado de alagados construídos mostrou-se eficiente somente na coleta do mês de fevereiro (76,4\%). Nos demais meses, foi observado um aporte de ferro total que variou entre $6,1 \%$ (jun/04) e 400,9\% (abr/05).

A remoção do ferro pode ocorrer através dos processos de adsorção das partículas ou substâncias dissolvidas em sítios nas plantas, microbiota e na matriz do solo, formação de complexos com a matéria orgânica, precipitação na forma de hidróxidos (ambientes aeróbios) e de sulfetos (anaeróbios), retenção por parte da vegetação dos hidróxidos de ferro formados, co-precipitação com óxidos de manganês e 
carbonato de cálcio e assimilação pela vegetação (principalmente na estação de crescimento) (ESTEVES, 1988; KADLEC et al., 2000; LEITÃO et al., 2006; OBARSKA-PEMPKOWIAK, 2000; VYMAZAL, 1998).

$\mathrm{O}$ aumento da concentração de ferro total da água deve estar relacionado à morte e decomposição das macrófitas (aguapé e alface d’água), as quais possuem elevados valores de ferro (acima de $8500 \mathrm{ppm}$ ) em seus tecidos (ANTUNES ${ }^{21}$, em fase de elaboração). Outra possível fonte de ferro que possa justificar tal aumento é a lixiviação do ferro existente no solo (sistema DHS), verificado antes do plantio do arroz, que variou de 106 a 183ppm, para o ano de 2004. Pode ter ocorrido também a lixiviação do ferro acumulado no sedimento durante a operação do sistema.

A taxa de remoção total do sistema foi negativa em 2004 e 2005, apresentando um acréscimo de $106,7 \%$ e 162,4\% respectivamente. Outros estudos relacionados com a remoção de ferro através de alagados construídos apresentaram eficiências positivas. Nos Estados Unidos, sistemas combinados utilizados para tratar percolados de aterro sanitário apresentaram eficiências de 89,7\% na Flórida (DEBUSK\& MERRICK ${ }^{22}, 1989$ apud KADLEC et al., 2000), 97\% em Minnesota (KADLEC et al., 2000) e variou de 43,6 a 81,9\% em Nova Iorque (SURFACE et al., 1993).

No Brasil, Jucá (2003) obteve uma eficiência de remoção 25,6\% do ferro total do chorume, com a utilização de apenas um canal de macrófitas emergentes de fluxo subsuperficial. Cecconello (2005), trabalhando também com percolados, verificou taxas de remoção de 71 a $93 \%$.

Manfrinato (1989), no tratamento de efluentes domésticos, observou uma eficiência de remoção positiva após a passagem do efluente pelo sistema de macrófitas e solos filtrantes. A eficiência de remoção total variou de 36,7 a $97,3 \%$. No tratamento do mesmo efluente, só que com um sistema de solos filtrantes, a autora verificou taxas de 66,9 a $90,6 \%$.

\footnotetext{
${ }^{21}$ Antunes, R. (em fase de elaboração). Dissertação (Mestrado) - Escola de Engenharia de São Carlos, Universidade de São Paulo, São Carlos.

${ }^{22}$ DEBUSK, T; MERRICK, P. (1989). Summary of operational and research data for the Reddy Creek improvement district wetland-based wastewater treatment system (WTS2). Report of March.
} 


\subsubsection{Manganês Total}

Os valores de manganês total da água obtidos nos pontos de coleta em 2004 e 2005 estão representados na figura 57.

A concentração medida em 2004 na entrada do alagado (P1) variou entre 0,06mg. $\mathrm{L}^{-1}$ (mar) e $0,37 \mathrm{mg} . \mathrm{L}^{-1}$ (jun), no ponto 2 entre $0,03 \mathrm{mg} \cdot \mathrm{L}^{-1}$ (fev/mar) e $0,09 \mathrm{mg} . \mathrm{L}^{-}$ ${ }^{1}$ (jun) e, na saída do sistema (P3), entre $<0,02 \mathrm{mg} \cdot \mathrm{L}^{-1}$ (fev) e $0,4 \mathrm{mg} \cdot \mathrm{L}^{-1}$ (jun).

Em 2005, a concentração de manganês total no P1 variou entre $0,09 \mathrm{mg} . \mathrm{L}^{-1}$ (jul) e $0,18 \mathrm{mg} \cdot \mathrm{L}^{-1}$ (mai). Nas amostras coletadas no ponto 2 , os valores variaram de $0,03 \mathrm{mg} \cdot \mathrm{L}^{-1}$ (jul) e $0,31 \mathrm{mg} \cdot \mathrm{L}^{-1}$ (mar) e no ponto 3 , de $0,02 \mathrm{mg} \cdot \mathrm{L}^{-1}$ (ago) a $0,07 \mathrm{mg} \cdot \mathrm{L}^{-1}$ (abr).

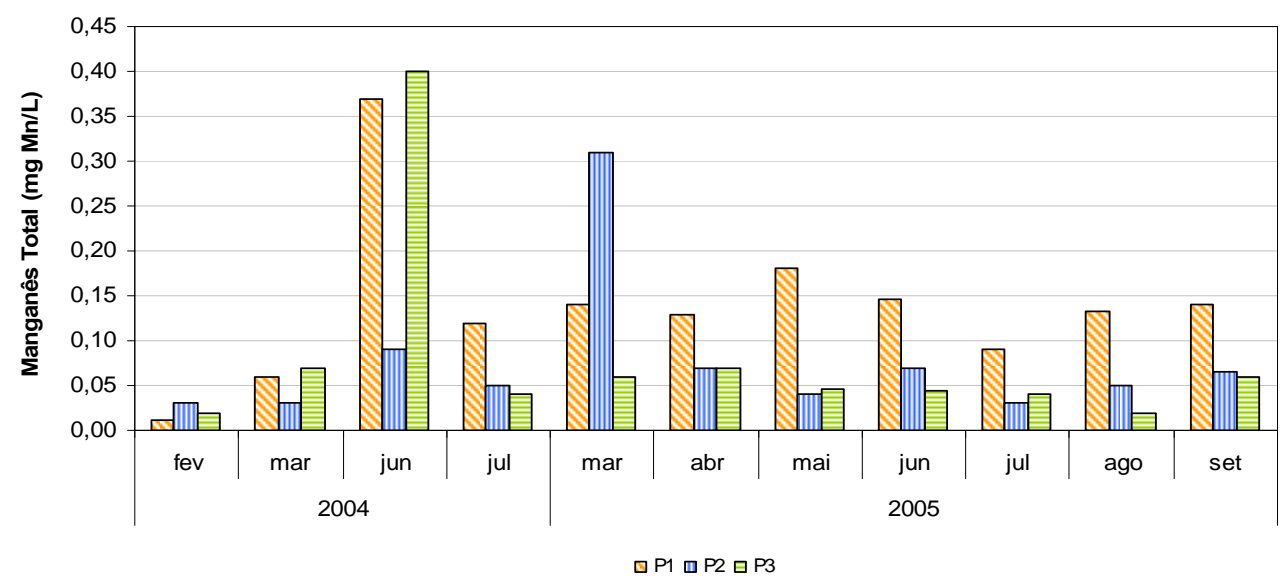

Figura 57: Variação dos valores de manganês total da água durante o período de coleta de 2004 e 2005 nas etapas do sistema de alagados construídos. Em fevereiro de 2004, o valor encontrado para o P3 foi inferior a $0,02 \mathrm{mg} \cdot \mathrm{L}^{1}$.

Os resultados obtidos com a análise estatística SAS e Teste de Tukey podem ser observados na tabela 30. Letras distintas indicam diferenças significativas pelo Teste de Tukey a $5 \%(\mathrm{p} \leq 0,05)$.

Tabela 30: Resultado do Teste de Tukey para a variável manganês total

\begin{tabular}{ccc}
\hline \multirow{2}{*}{ Pontos } & \multicolumn{2}{c}{ Média (mg. L $^{\mathbf{1}}$ ) } \\
& $\mathbf{2 0 0 4}$ & $\mathbf{2 0 0 5}$ \\
\hline 1 & $0,17 \mathrm{a}$ & $1,14 \mathrm{X}$ \\
2 & $0,05 \mathrm{a}$ & $0,09 \mathrm{XY}$ \\
3 & $0,13 \mathrm{a}$ & $0,05 \mathrm{Y}$ \\
\hline
\end{tabular}

Durante o ano de 2004, foi observada uma redução na concentração média de manganês total após a passagem pelos canais e um acréscimo após os solos filtrantes. 
No entanto, segundo o teste estatístico, os valores médios encontrados nos pontos de coleta não são significativamente diferentes.

Em 2005, observou-se uma remoção da concentração média do manganês ao longo das etapas do sistema. E com um nível de 5\% de significância, pode-se afirmar que houve uma remoção significativa após a passagem pelos alagados construídos.

As eficiências de remoção parcial e a total de manganês total da água, durante o período de estudo em 2004 e 2005, podem ser visualizadas na figura 58.

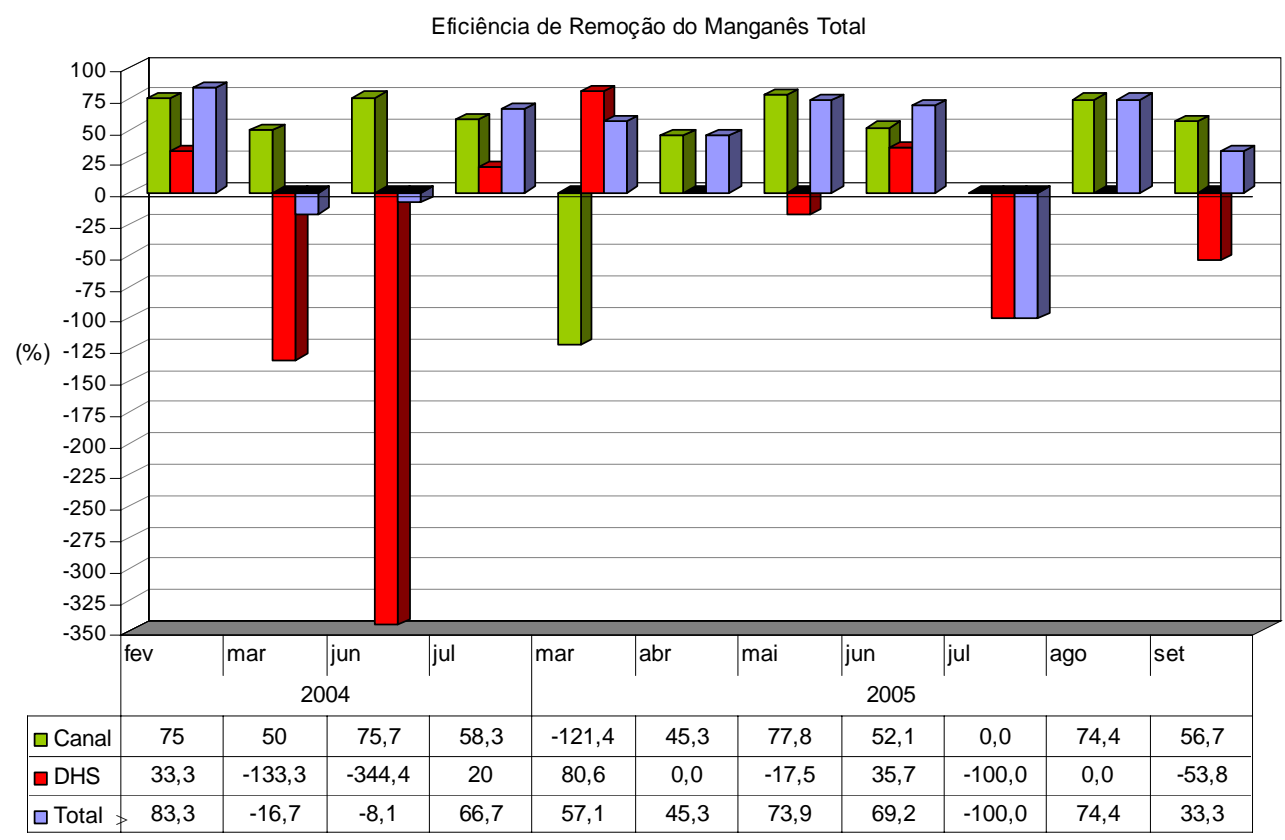

Figura 58: Eficiência total e de cada uma das etapas do sistema de alagados construídos na remoção de manganês total durante o período de coleta de 2004 e 2005.

O conjunto de canais (decantação e macrófitas) apresentou uma taxa positiva de remoção na maioria dos meses de coleta, que variou entre 45,3\% (abr/05) e 77,8\% (mai/05). Somente na coleta de março de 2005 que foi verificado um aumento da concentração $(121,4 \%)$ de manganês total. No mês de julho de 2005 não houve remoção.

O sistema de solos filtrantes mostrou-se eficiente para a maioria dos meses de coleta. A taxa de remoção variou na faixa de $20 \%$ (jul/04) a 80,6\% (mar/05). Nas coletas do mês de março e junho de 2004 e maio e julho de 2005, foram observados acréscimos, que variaram entre 17,5\% (mai/05) e 344,4\% (jun/04).

Após a passagem pelo sistema combinado de alagados construídos, foi observada uma redução da concentração de manganês total da água na maioria dos 
meses de estudo. Uma taxa de acréscimo na concentração de manganês total da água foi verificada nas coletas do mês de março $(16,7 \%)$ e junho $(8,1 \%)$ de 2004 e julho (100\%) de 2005. A eficiência de remoção total do sistema variou de 33,3\% (set/05) a mais de $83,3 \%(\mathrm{fev} / 04)$.

A remoção do manganês, assim como já citado para o ferro total, pode ocorrer através dos processos de adsorção das partículas ou substâncias dissolvidas em sítios das plantas, microbiota e matriz do solo, formação de complexos com a matéria orgânica, precipitação na forma de hidróxidos (ambientes aeróbios) e de sulfetos (anaeróbios), co-precipitação com hidróxidos de ferro, retenção por parte da vegetação dos hidróxidos formados e assimilação pela vegetação (principalmente na estação de crescimento) e microbiota (ESTEVES, 1988; KADLEC et al., 2000; LEITÃO et al., 2006; OBARSKA-PEMPKOWIAK, 2000; VYMAZAL, 1998).

$\mathrm{O}$ aumento da concentração de manganês total da água, no conjunto de canais em março de 2005, deve estar relacionado à morte e decomposição das macrófitas (aguapé e alface d’água), as quais possuem valores altos de manganês (acima de 250 ppm) em seus tecidos. Somado a este fator, pode também ter ocorrido uma possível perda do manganês retido nos solos durante o funcionamento do sistema.

No sistema DHS, é possível que tenha ocorrido uma solubilização das partículas de manganês do solo com a inundação do sistema (MEIORIN, 1989), além da liberação para a coluna d’água do manganês retido durante o seu funcionamento. Pode ter ocorrido também uma liberação do manganês que estava adsorvido nas plantas e na microbiota na competição com outros íons pelo s sítios de troca catiônica.

A taxa de remoção total do sistema foi superior a 31,3\% em 2004 e de 36,2\% em 2005 (valor reduzido devido ao desempenho negativo do sistema em julho).

Outros estudos relacionados com a remoção de manganês total através de alagados construídos apresentaram taxas de eficiência mais altas. Nos Estados Unidos, os sistemas combinados utilizados para tratar percolados de aterro sanitário apresentaram eficiências de 52\% na Flórida (DEBUSK \& MERRICK ${ }^{23}, 1989$ apud KADLEC et al., 2000), 91\% em Minnesota (KADLEC et al., 2000) e variou de 20,6 a $70,2 \%$ em Nova Iorque (SURFACE et al., 1993).

${ }^{23}$ DEBUSK, T; MERRICK, P. (1989). Summary of operational and research data for the Reddy Creek improvement district wetland-based wastewater treatment system (WTS2). Report of March. 
No Brasil, Jucá (2003) obteve uma eficiência de 64,2\% do manganês total do chorume, com a utilização de apenas um canal de macrófitas emergentes de fluxo subsuperficial.

Manfrinato (1989), trabalhando com efluentes domésticos, obteve taxas de remoção que variaram de 10 a 95,2\% após a passagem do efluente pelo sistema de macrófitas e solos filtrantes. No entanto, depois de sete meses de estudos com taxas positivas de remoção, a autora começou a observar um aumento da concentração de manganês após a passagem pelos solos filtrantes, verificando um acréscimo na faixa de 367 a 1900\%. No tratamento do mesmo efluente, só que com um sistema de solos filtrantes consecutivos, foram obtidas taxas de remoção superiores a $80 \%$ durante os três primeiros meses de estudo. Nos outros meses, foi observado um aporte de manganês para a coluna d’água $(5,9$ a $341 \%)$.

A utilização de sistemas com dois solos filtrantes para tratamento de águas contaminadas por metais alcançou uma eficiência de remoção de $100 \%$ durante os primeiros 2 meses de monitoramento e depois começou a decair atingindo uma taxa de 42,2\% no final de 5 meses (CHENG et al., 2002). Salati e colaboradores (1999), no tratamento das águas do Rio Cotia, observaram uma taxa de remoção superior a $87 \%$. No entanto, um acréscimo de $46,5 \%$ foi observado após a passagem pelos canais com tempo de retenção hidráulico de 5 dias.

Os dados obtidos para o ponto de entrada do sistema mostram, que na maioria dos meses de estudo, a concentração de manganês total medida apresentou valores acima do estabelecido pela Resolução CONAMA 357/2005 para águas doces classe 2 (BRASIL, 2005). Após a passagem pelo sistema de alagados construídos, no entanto, o efluente atendeu a resolução, apresentando valores abaixo de $0,1 \mathrm{mg} \cdot \mathrm{L}^{-1}$.

\subsubsection{Bário, Cobre, Cromo, Mercúrio, Prata e Zinco}

Como a concentração dos metais na água: bário, cobre, cromo, mercúrio, prata, e zinco, ficaram abaixo do limite de quantificação do método utilizado durante o período de estudos de 2004 e 2005, optou-se por representar os valores em uma tabela (Tab. 31). 
Tabela 31: Variação dos valores de bário, cobre, cromo, mercúrio, prata e zinco na água durante o período de coleta de 2004 e 2005 nas etapas do sistema de alagados construídos.

\begin{tabular}{|c|c|c|c|c|c|c|c|c|c|}
\hline & \multirow{2}{*}{\multicolumn{2}{|c|}{$\begin{array}{l}\text { Período de } \\
\text { estudo }\end{array}$}} & \multicolumn{7}{|c|}{ METAIS (mg. $\left.\mathrm{L}^{-1}\right)$} \\
\hline & & & Bário & Cobre & Cromo & Mercúrio & Prata & Selênio & Zinco \\
\hline \multirow{12}{*}{$\begin{array}{l}2 \\
0 \\
0 \\
4\end{array}$} & \multirow{3}{*}{ Fevereiro } & P1 & $<0,05$ & $<0,02$ & $<0,003$ & $<0,0005$ & $<0,001$ & 0,01 & $<0,05$ \\
\hline & & P2 & 0,05 & $<0,02$ & $<0,003$ & $<0,0005$ & $<0,001$ & 0,01 & $<0,05$ \\
\hline & & P3 & $<0,05$ & $<0,02$ & $<0,003$ & $<0,0005$ & $<0,001$ & 0,01 & $<0,05$ \\
\hline & \multirow{3}{*}{ Março } & $\mathrm{P} 1$ & $<0,05$ & $<0,02$ & $<0,003$ & $<0,0005$ & 0,001 & $<0,001$ & $<0,05$ \\
\hline & & P2 & 0,05 & $<0,02$ & $<0,003$ & $<0,0005$ & $<0,001$ & $<0,001$ & $<0,05$ \\
\hline & & $\mathrm{P} 3$ & $<0,05$ & $<0,02$ & $<0,003$ & $<0,0005$ & $<0,001$ & $<0,001$ & $<0,05$ \\
\hline & \multirow{3}{*}{ Junho } & P1 & $<0,05$ & $<0,02$ & $<0,003$ & $<0,0005$ & $<0,001$ & $<0,001$ & $<0,05$ \\
\hline & & P2 & $<0,05$ & $<0,02$ & $<0,003$ & $<0,0005$ & $<0,001$ & $<0,001$ & $<0,05$ \\
\hline & & $\mathrm{P} 3$ & $<0,05$ & $<0,02$ & $<0,003$ & $<0,0005$ & $<0,001$ & $<0,001$ & $<0,05$ \\
\hline & \multirow{3}{*}{ Julho } & P1 & 0,05 & $<0,02$ & $<0,003$ & $<0,0005$ & $<0,001$ & $<0,001$ & $<0,05$ \\
\hline & & $\mathrm{P} 2$ & 0,05 & $<0,02$ & $<0,003$ & $<0,0005$ & $<0,001$ & $<0,001$ & $<0,05$ \\
\hline & & $\mathrm{P} 3$ & $<0,05$ & $<0,02$ & $<0,003$ & $<0,0005$ & $<0,001$ & $<0,001$ & $<0,05$ \\
\hline \multirow{4}{*}{$\begin{array}{l}2 \\
0 \\
0 \\
5\end{array}$} & \multirow{4}{*}{ Junho } & & & & & & & & \\
\hline & & P1 & $<0,05$ & $<0,02$ & $<0,003$ & $<0,0005$ & 0,001 & $<0,001$ & $<0,05$ \\
\hline & & $\mathrm{P} 2$ & $*$ & $*$ & $*$ & $*$ & $*$ & $*$ & $*$ \\
\hline & & P3 & $<0,05$ & $<0,02$ & $<0,003$ & $<0,0005$ & $<0,001$ & $<0,001$ & $<0,05$ \\
\hline
\end{tabular}

Como a maioria dos valores encontrados está abaixo do limite de quantificação, não foi possível calcular as taxa de remoção do sistema.

No entanto, outros trabalhos com concentrações mais elevadas destes metais apresentaram taxas de remoção positiva. Kadlec e colaboradores (2000), durante o primeiro ano de operação de uma estação em Minnesota, reportaram uma eficiência de remoção de 19\% para cobre, $67 \%$ para cromo, $75 \%$ para mercúrio e de $93 \%$ para zinco.

$\mathrm{Na}$ simulação de águas contaminadas com metais pesados, realizada por Cheng e outros autores (2002), foi verificada uma remoção de $100 \%$ para cobre e zinco durante 5 meses de monitoramento.

Jucá (2003) e Cecconello (2005), no tratamento de lixiviados de aterro sanitário, observaram taxas de remoção de $46,9 \%$ e na faixa de 44 a 99,5\% respectivamente.

Segundo Kadlec e colaboradores (2000), os processos de remoção destes metais são semelhantes aos já descritos para cádmio e chumbo.

Durante o período de estudo, todos os pontos de coleta apresentaram concentrações de bário, cobre, cromo, prata, selênio e zinco que atenderam a Resolução CONAMA 357/2005 para águas doces classe 2 (BRASIL, 2005). No entanto, com relação ao parâmetro mercúrio, a resolução estabelece o limite de $0,0002 \mathrm{mg} . \mathrm{L}^{-1}$ e os valores encontrados ficaram abaixo de $0,0005 \mathrm{mg} . \mathrm{L}^{-1}$, não sendo possível afirmar se o efluente atende ou não a resolução. 


\subsubsection{Fenol}

A variação dos valores de fenol da água em cada um dos pontos de coleta em 2005 está representada na Figura 59.

A concentração de fenóis medida na entrada do sistema (P1) variou entre 0,0001 mg.L-1 (abr) e 0,0091 mg. $\mathrm{L}^{-1}$ (ago); no ponto 2 , na faixa de $0,0006 \mathrm{mg} / \mathrm{L}^{-1}$ (mai) a 0,0058mg. $\mathrm{L}^{-1}$ (mar/set) e, na saída do sistema (P3) variou entre 0,0005mg.L $\mathrm{L}^{-1}$ (jul) e 0,0044mg. $\mathrm{L}^{-1}$ (mar). Na coleta de abril, não foi detectada a presença de fenol na água no P3.

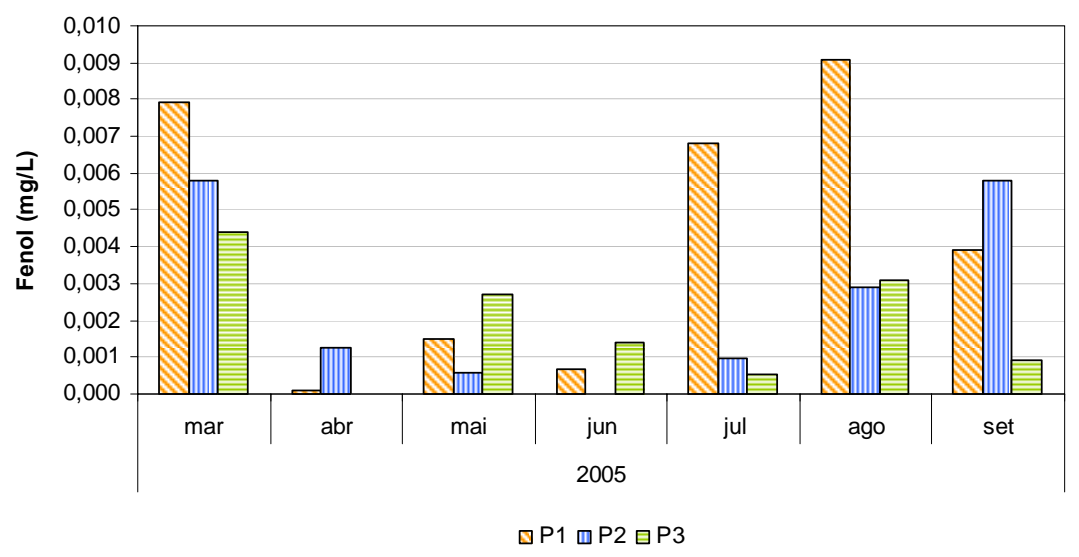

Figura 59: Variação dos valores de fenol da água durante o período de coleta de 2005 nas etapas do sistema de alagados construídos. A coleta no P2 em junho foi prejudicada.

Os resultados obtidos com a análise estatística SAS e Teste de Tukey podem ser observados na tabela 32. Letras distintas indicam diferenças significativas pelo Teste de Tukey a $5 \%(\mathrm{p} \leq 0,05)$.

Tabela 32: Resultado do Teste de Tukey para a variável fenol.

\begin{tabular}{cc}
\hline Pontos & $\begin{array}{c}\text { Média (mg. } \mathbf{L}^{\mathbf{1}} \text { ) } \\
\text { 2004 }\end{array}$ \\
\hline 1 & $0,0043 \mathrm{a}$ \\
2 & $0,0025 \mathrm{a}$ \\
3 & $0,0019 \mathrm{a}$ \\
\hline
\end{tabular}

Durante o período de estudo foi observada uma redução as concentração de fenol após a passagem pelas etapas do sistema, no entanto, segundo o teste estatístico, não há diferenças significativas entre pontos de coleta. Apesar do resultado do teste, aceita-se que houve uma remoção significativa da concentração de fenol após a passagem pelo sistema de alagados nos meses de março, julho, agosto e setembro de 2005 (remoção superior a 50\%). 
As eficiências de remoção parcial e a total de fenol da água, durante o período de estudo em 2005, podem ser visualizadas na figura 60 .

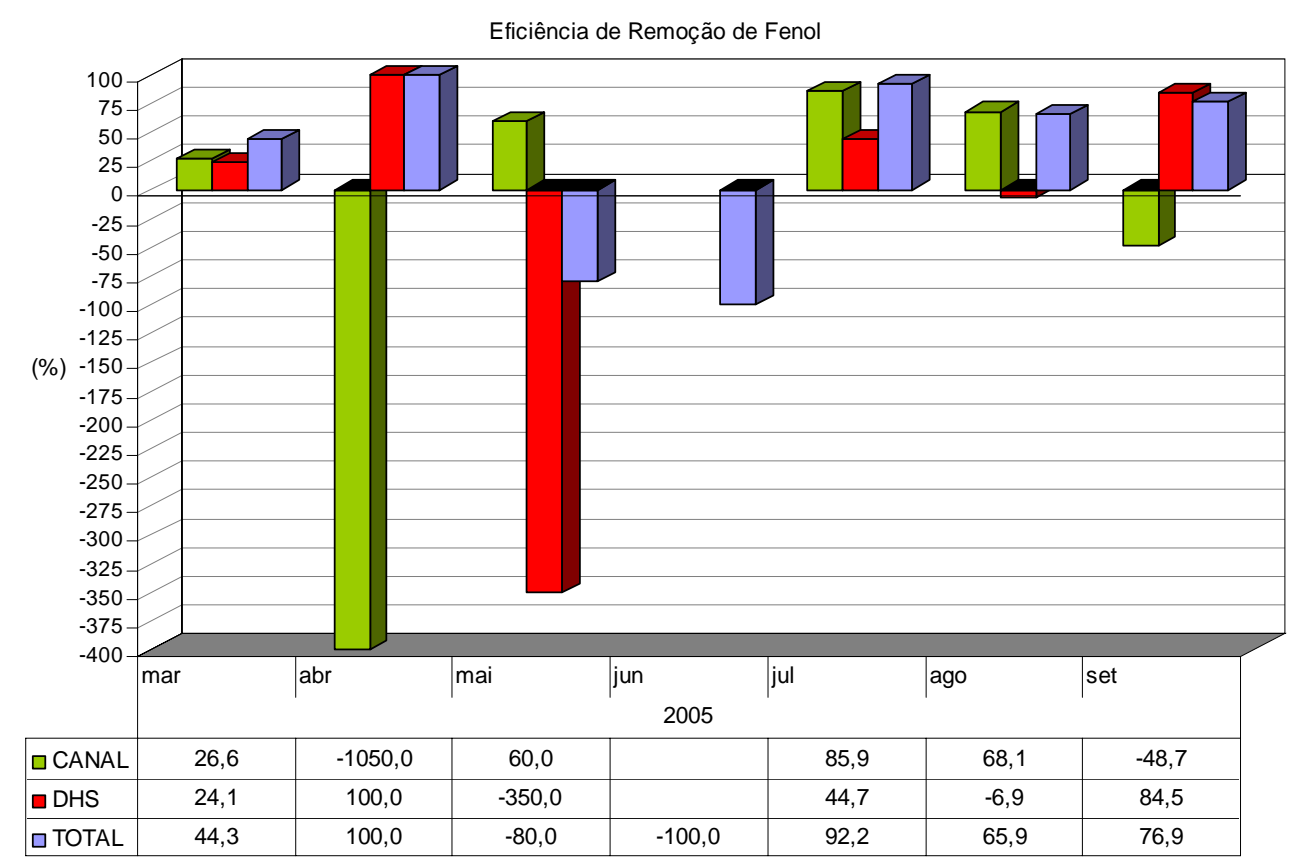

Figura 60: Eficiência total e de cada uma das etapas do sistema de alagados construídos na remoção de fenol durante o período de coleta de 2005.

O conjunto de canais (decantação e macrófitas) apresentou uma taxa positiva de remoção na maioria dos meses de coleta, que variou entre 26,6\% (mar) e 85,9\% (jul). Somente na coleta de abril e setembro foi verificado uma taxa de acréscimo de $1050 \%$ e $48,7 \%$ respectivamente, na concentração de fenol.

O sistema de solos filtrantes também se mostrou eficiente para a maioria dos meses de coleta. A taxa de remoção variou na faixa de 24,1\% (mar) a 100\% (abr). Nas coletas do mês de maio e de agosto foram observados, respectivamente, acréscimos de $350 \%$ e $6,9 \%$ na concentração de fenol na água.

Após a passagem pelo sistema combinado de alagados construídos, verificou-se uma redução da concentração de fenol da água na maioria dos meses de estudo. Exceto para as coletas do mês de maio $(-80 \%)$ e junho $(-100 \%)$. A eficiência de remoção total do sistema variou de 44,3\% (mar) a 100\% (abr).

O fenol pode ser removido do sistema através da adsorção as partículas de matéria orgânica e partículas argilosas do solo e degradação microbiana por bactérias (Pseudomonas) e fungos (LEITÃO et al., 2006).

A eficiência de remoção total do sistema em 2005 foi de $28,5 \%$ devido aos acréscimos observados na coleta de maio e junho. Não existem muitos trabalhos sobre a 
remoção de fenóis em sistemas de alagados construídos, a maioria é com relação a reatores. No Brasil pode-se citar o estudo desenvolvido para tratamento do efluente doméstico, industrial e de escoamento da indústria Cyanamid Química (Iracemápolis/SP), com uma taxa de remoção de 96\% (SALATI FILHO, SALATI Eneida \& SALATI Enéas).

Salati e colaboradores, no pré-tratamento das águas do Rio Cotia (SP) alcançaram eficiências de 37,5\% (2,5 dias de retenção) e 100\% (5 dias de retenção).

Durante todo o período de estudo em 2005, exceto na coleta do mês de abril, o efluente coletado na lagoa apresentou uma concentração de fenol superior à estabelecida pela Resolução CONAMA 357/2005 para águas doces de classe 2 (BRASIL, 2005). Após a passagem pelo sistema combinado de alagados construídos, somente as coletas dos meses de abril, julho e setembro atenderam ao limite proposto pela resolução, apresentando concentrações menores do que $0,003 \mathrm{mg} \cdot \mathrm{L}^{-1}$.

\subsection{Variáveis hidrobiológicas}

\subsubsection{Coliformes Totais}

Os valores obtidos para coliformes totais nos pontos de coleta em 2004 estão representados na figura 61 .

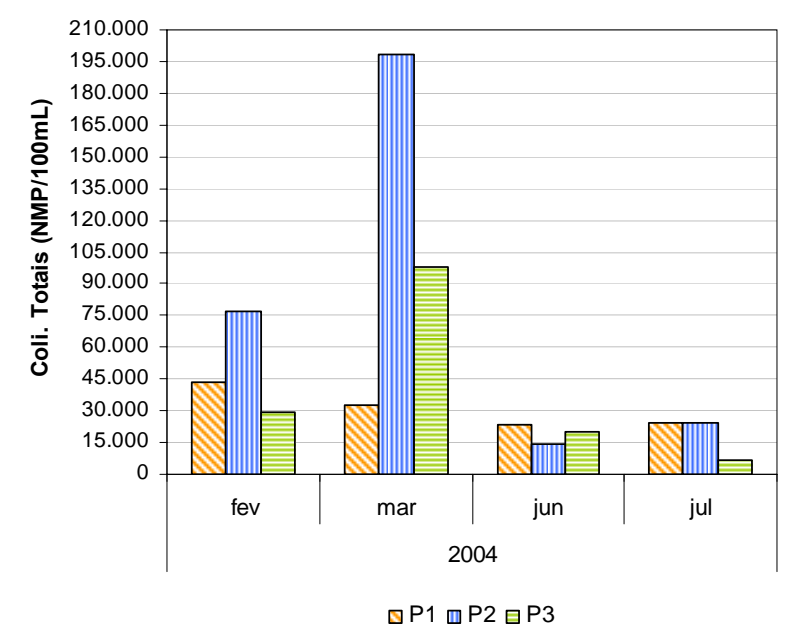

Figura 61: Variação dos valores de coliformes totais da água durante o período de coleta de 2004 nas etapas do sistema de alagados construídos. 
A quantidade de coliformes totais encontrada na água no ponto 1 variou entre $23.590 \mathrm{NMP} / 100 \mathrm{ml}$ (jun) e $43.520 \mathrm{NMP} / 100 \mathrm{ml}$ (fev). No ponto 2, o número variou entre 14.136NMP/100ml (jun) a 198.630NMP/100ml (mar), maior valor encontrado durante o período de estudo.

Os resultados obtidos com a análise estatística SAS e Teste de Tukey podem ser observados na tabela 33. Letras distintas indicam diferenças significativas pelo Teste de Tukey a $5 \%(\mathrm{p} \leq 0,05)$.

Tabela 33: Resultado do Teste de Tukey para a variável coliformes totais.

\begin{tabular}{cc}
\hline Pontos & $\begin{array}{c}\text { Média } \\
\text { (NMP/100ml) } \\
\text { 2004 }\end{array}$ \\
\hline 1 & $31031 \mathrm{a}$ \\
2 & $78492 \mathrm{a}$ \\
3 & $38465 \mathrm{a}$ \\
\hline
\end{tabular}

A análise dos resultados mostra um aumento da quantidade de coliformes totais após a passagem pelos canais e uma redução após os solos filtrantes, no entanto, essas variações não foram significativas segundo o teste estatístico utilizado.

Ao se observar os valores mensais encontrados em cada um dos pontos de coleta separadamente, acredita-se que houve um aumento significativo da concentração de coliformes totais após a passagem pelo sistema de canais e uma redução, também significativa, após a passagem pelos solos filtrantes em fevereiro e março de 2004. A maior média encontrada foi no P2 e a menor no P1.

Durante todo o período de estudo de 2004, nenhum ponto de coleta apresentou uma quantidade de coliformes totais abaixo do limite de 5.000NMP/100ML, estipulado pela Resolução CONAMA 357/2005 para águas doces de classe 2 (BRASIL, 2005).

As eficiências de remoção parcial e a total de coliformes totais da água, durante o período de estudo em 2004, podem ser visualizadas na figura 62 . 


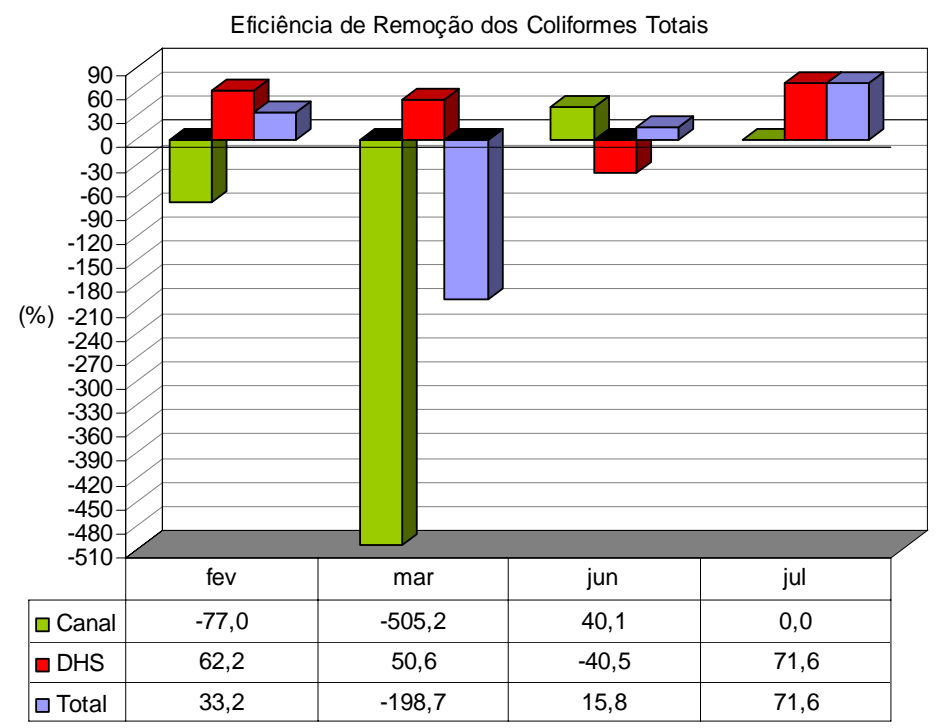

Figura 62: Eficiência total e de cada uma das etapas do sistema de alagados construídos na remoção de coliformes totais durante o período de coleta de 2004.

Os canais apresentaram um desempenho satisfatório de remoção somente na coleta realizada no mês de junho (40,1\%). Nos meses de fevereiro e março, a eficiência de remoção foi negativa, com um acréscimo de $77 \%$ e $505,2 \%$ respectivamente. No mês de julho não ocorreu remoção.

Os solos filtrantes apresentaram em sua maioria uma eficiência de remoção positiva que variou entre $50,6 \%$ (mar) e $71,6 \%$ (jul). No entanto, foi observado um acréscimo de $40,5 \%$ de coliformes totais no efluente após a passagem pelos solos filtrantes no mês de junho.

A eficiência de remoção total do sistema variou entre 15,8\% (jun) e 71,6\% (jul). Contudo, na coleta do mês de março o desempenho não foi satisfatório, com uma taxa de acréscimo de 198,7\%, possivelmente devido ao grande aumento da quantidade de coliformes totais após a passagem do efluente pelos canais.

\subsubsection{Coliformes Termotolerantes}

A variação dos valores de coliformes termotolerantes em cada um dos pontos de coleta em 2004 está representada na Figura 63.

A quantidade encontrada na água no ponto 1 variou entre 26NMP/100ml (mar) e $850 \mathrm{NMP} / 100 \mathrm{ml}$ (fev), maior valor encontrado no período de estudo. No ponto 2 , o número variou entre 20NMP/100ml (mar/jun) e 155NMP/100ml (fev). No ponto localizado na saída do alagado construído, a quantidade de coliformes variou entre 
3NMP/100ml (fevereiro - menor valor encontrado no período de estudo) e $630 \mathrm{NMP} / 100 \mathrm{ml}$ (mar).

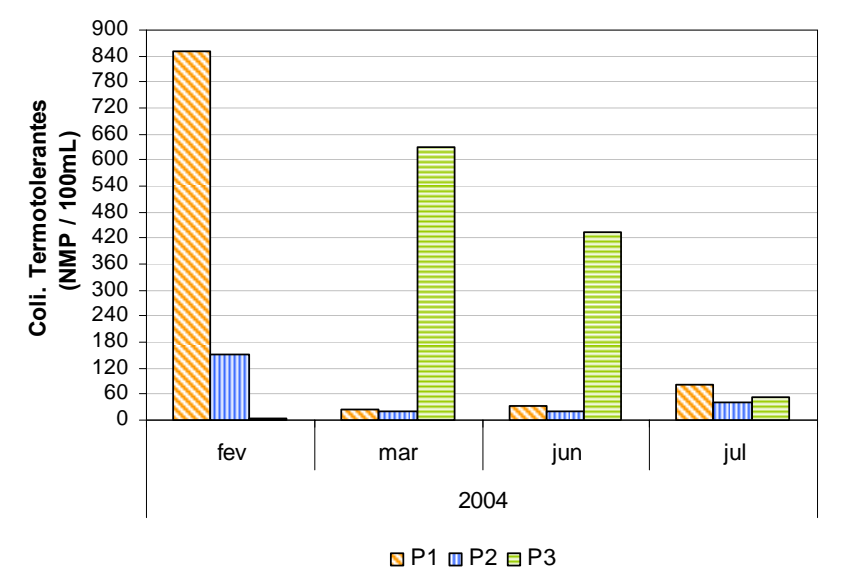

Figura 63: Variação dos valores de coliformes termotolerantes da água durante o período de coleta de 2004 nas etapas do sistema de alagados construídos.

Os resultados obtidos com a análise estatística SAS e Teste de Tukey podem ser observados na tabela 34. Letras distintas indicam diferenças significativas pelo Teste de Tukey a $5 \%(\mathrm{p} \leq 0,05)$.

Tabela 34: Resultado do Teste de Tukey para a variável coliformes termotolerantes

\begin{tabular}{cc}
\hline Pontos & $\begin{array}{c}\text { Média } \\
\text { (NMP/100ml) } \\
\text { 2004 }\end{array}$ \\
\hline 1 & $247 \mathrm{a}$ \\
2 & $58 \mathrm{a}$ \\
3 & $279 \mathrm{a}$ \\
\hline
\end{tabular}

Os valores médios da quantidade de coliformes termotolerantes em cada um dos pontos de coleta mostram uma redução após a passagem pelos canais e uma aumento após os solos filtrantes, no entanto, não há diferença significativa entre os pontos de coleta. Segundo a análise dos dados é possível observar que houve uma remoção significativa após a passagem pelo sistema de canais somente no mês de fevereiro, enquanto que o acréscimo ocorreu nos meses de março e junho de 2004 após a passagem pelos solos filtrantes. A maior média encontrada foi no P3 e a menor no P2.

Durante todo o período de estudo de 2004, todos os pontos de coleta apresentaram uma quantidade de coliformes termotolerantes abaixo do limite de 1.000NMP/100ML, estipulado pela Resolução CONAMA 357/2005 para águas doces de classe 2 (BRASIL, 2005). 
As eficiências de remoção parcial e a total de coliformes termotolerantes da água, durante o período de estudo em 2004, podem ser visualizadas na figura 64 .

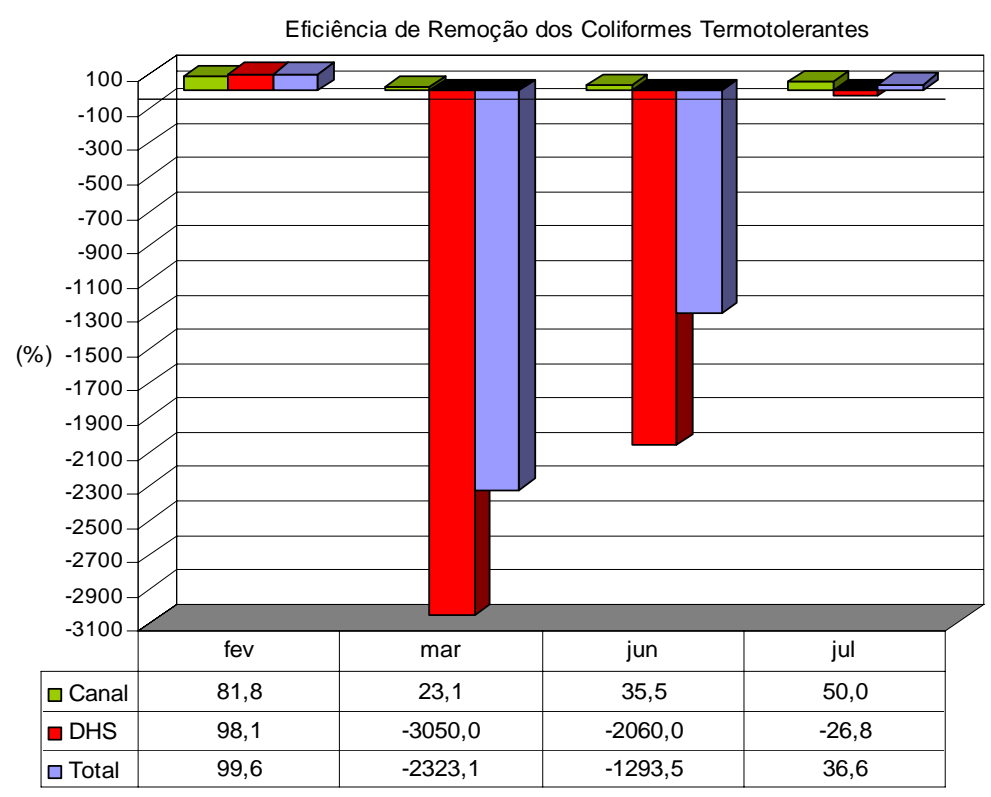

Figura 64: Eficiência total e de cada uma das etapas do sistema de alagados construídos na remoção de coliformes termotolerantes durante o período de coleta de 2004.

O canal de decantação e o de macrófitas apresentaram em todas as coletas uma taxa positiva de remoção que variou entre $23,1 \%$ (mar) e $81,8 \%$ (fev).

Os solos filtrantes apresentaram em sua maioria uma eficiência de remoção negativa, com uma taxa de acréscimo que variou de entre $26,8 \%$ (jul) e $3050 \%$ (mar). Somente a coleta do mês de fevereiro apresentou uma taxa de remoção positiva $(98,1 \%)$.

A eficiência de remoção total do sistema foi positiva para os meses de fevereiro $(99,6 \%)$ e julho (36,6\%). E para as coletas em março e junho, foi observado um aumento de $2323,1 \%$ e $1293,5 \%$ respectivamente após a passagem pelos alagados construídos.

A remoção de coliformes nos alagados está relacionada a processos físicos, químicos e biológicos. Como físicos têm-se a filtração, sedimentação e exposição aos raios ultravioleta. A oxidação, exposição a biocidas excretados por certas plantas e adsorção a matéria orgânica e a biomassa radicular são os processos químicos. Os processos biológicos são morte natural, ataque por vírus e outras bactérias e predação 
são os biológicos. (GERSBERG, GEARHEART \& IVES, 1989; HYDE \& ROSS $^{24}$, 1984 apud WATSON et al., 1989; KADLEC et al., 2000).

O aumento da concentração de coliformes encontrada após a passagem pelos canais pode estar relacionado à liberação para o meio das bactérias filtradas pelas plantas transplantadas e até mesmo a proliferação das bactérias presentes, além dos pássaros que visitam as plantas. Segundo a Resolução CONAMA 357/2005 (BRASIL, 2005), os coliformes termotolerantes, além de estarem presentes nas fezes humanas e de animais homeotérmicos, ocorrem em solos, plantas e outras matrizes ambientais que não tenham sido contaminadas por material fecal.

Nos solos filtrantes, o aumento da quantidade de coliformes fecais provavelmente ocorreu devido à presença de animais atraídos pelo arroz (macacos, quatis, pacas, pássaros) e o depósito direto de fezes.

No entanto, apesar de baixas eficiências de remoção e de grandes acréscimos após a passagem pelo sistema combinado de alagados construídos em 2004, é válido ressaltar que a estimativa média de remoção de microrganismos patogênicos nestes tipos de sistema supera os 90\% (FBDS, 2004), assim como observado em fevereiro de 2004.

Manfrinato (1989) ao estudar um sistema composto por canal de macrófitas e solos filtrantes para tratamento de esgoto observou uma remoção na faixa de 75,3 a 99,9\%. Ao tratar esse mesmo efluente com um sistema de solos filtrantes em seqüência, a autora alcançou taxas de 46,5 a 99,9\% para coliformes totais e de 94,3 a 99,9\% para coliformes fecais.

A utilização de um sistema de alagados construídos composto por dois canais de macrófitas emergentes para purificação do efluente de uma indústria alimentícia (efluente do processamento, doméstico e de escoamento) obteve uma eficiência de remoção média de $99,6 \%$ para coliformes totais e 94,7\% para coliformes fecais (VRHOVSEK, KUKANJA \& BULC, 1996).

Kadlec e colaboradores (2000) e os pesquisadores Steiner e Combs (1993), utilizando um sistema de alagados construídos para tratamento secundário de águas de esgoto, observaram uma remoção de 99\% para coliformes fecais.

${ }^{24}$ HYDE, H.C; ROSS, R.S. (1984). Technology Assessment of Wetlands for Municipal Wastewater Treatment, U.S. EPA Municipal Environmental Research Laboratory, Cincinnati, OH 
Na purificação das águas do Rio Retiro para abastecimento público, Elias (2003) verificou taxas de remoção superiores a $81,2 \%$ para coliformes totais e $95 \%$ para fecais. Cecconello (2005), no tratamento de chorume, alcançou taxas de remoção que variaram de $68,6 \%$ a $99,9 \%$ para totais e de 82,9 a $99,9 \%$ para fecais.

Uma estação experimental composta por solos filtrantes e um canal de macrófitas em Barueri, São Paulo (SALATI FILHO, SALATI Eneida \& SALATI Enéas, 1999), apresentou uma eficiência de 98\% para coliformes totais e $100 \%$ para coliformes fecais. Valentim (2003) observou uma taxa de remoção que variou de 51 a 99\% para coliformes totais e de 70 a 94\% para E.coli. no tratamento secundário de esgotos domésticos.

Salati e demais autores (1999) verificaram uma taxa de remoção total de $88 \%$ para coliformes totais e $99,9 \%$ para coliformes fecais no pré-tratamento das águas do Rio Cotia. No entanto, foi observado um acréscimo da quantidade de coliformes fecais após a passagem pelos canais.

\section{CONCLUSÕES}

- De um modo geral, os resultados obtidos nas coletas durante o período de estudo de 2004 e de 2005, nas diferentes etapas do sistema, indicam o alcance de taxas de eficiência acima de 50\% para diversas variáveis analisadas, em especial para os elementos químicos responsáveis pela eutrofização dos corpos de água (nitrogênio albuminóide, nitrogênio amoniacal, nitrito e fósforo total) e para DQO, sulfato e turbidez.

- Quando analisado o conjunto de dados como um todo foi observado uma diferença significativa entre os dois anos de coleta $(p=0,022)$, com um nível de significância de 5\%. É importante salientar também que quando são analisadas as remoções nos pontos de coleta para cada variável, observa-se que as mesmas são diferentes entre os anos.

- O conjunto canal de decantação e canal de macrófitas flutuantes e emergentes foi eficiente na remoção média da maioria das variáveis analisadas no trabalho, contribuindo com a maior taxa de remoção total do sistema. No entanto, os canais apresentaram um desempenho médio negativo no ano de 2004, para 
coliformes totais e em 2005, para nitrogênio amoniacal e ferro total. Esta etapa do sistema apresentou uma eficiência positiva de remoção destas variáveis para a maioria dos meses de coleta, no entanto, as taxas de acréscimo observadas nos demais meses foram maiores do que as de remoção, contribuindo assim, para um valor negativo de eficiência.

- Apesar do mau funcionamento dos solos filtrantes, conseqüência provável da falta de manejo das macrófitas e de alternância das células (condição necessária para utilização dos solos), o sistema combinado de alagados construídos apresentou uma taxa de remoção total positiva para a maioria das variáveis, excetuando-se coliformes totais e termotolerantes e ferro total.

- Mesmo com eficiências de remoção positivas para a maioria das variáveis, reduções significativas, após a passagem pelo sistema, segundo o teste de Tukey (que utiliza valores médios), foram observadas apenas para $\mathrm{pH}$, dureza, sulfato, DQO, fósforo total e nitrogênio albuminóide em 2004. No período de 2005, foram as variáveis : $\mathrm{pH}$, turbidez, DQO, fósforo total, nitrogênio amoniacal e manganês total. Para cor (2004 e 2005) e turbidez (2004), os canais apresentaram uma remoção significativa, mas o possível revolvimento do solos e ressuspensão do material sedimentado nos solos filtrantes acarretaram em um aumento do valor medido na saída do sistema.

- É possível que uma maior taxa de remoção total das variáveis pela estação teria sido observada, se o canal de macrófitas e os solos filtrantes tivessem sido manejados corretamente (colheita/poda e alternância dos solos), como proposto inicialmente no projeto, e seus processos característicos de remoção mantidos. Como por exemplo, os processos aeróbios dos solos filtrantes: decomposição, nitrificação, oxidação de metais e formação de precipitados com hidróxidos ferro e manganês.

- As variáveis analisadas na entrada do sistema, que não atenderam os limites estabelecidos pela Resolução CONAMA 357/2005 para águas doces de classe 2 (BRASIL, 2005) foram: oxigênio dissolvido (jun/04), cor, $\mathrm{DBO}_{5}$, fósforo total, 
cádmio (jun/04), chumbo (jul/04), fenol e coliformes totais. Após a passagem pelo sistema não foi observado o enquadramento das variáveis: oxigênio dissolvido, $\mathrm{DBO}_{5}$, fenol (meses de março, maio, junho e agosto de 2005) e coliformes totais.

- O aumento de matéria orgânica em decomposição, resultante da não adaptação das plantas aquáticas no canal de macrófitas, provavelmente contribuiu para o aumento da concentração de muitas variáveis (cor, $\mathrm{DBO}_{5}$, fósforo total, nitrogênio albuminóide, ferro total, manganês total, dentre outros) na coluna d’água e, conseqüentemente, com uma redução da eficiência do sistema.

- Com relação aos coliformes totais e termotolerantes, o aumento observado provavelmente está relacionado com a visita dos pássaros e mamíferos do parque atraídos pelo arroz cultivado nas células de solos filtrantes. Além disso, pode também ser resultado dos coliformes presentes nos solos e plantas que foram lixiviados para a coluna d’água quando o sistema foi inundado e com o plantio das macrófitas.

- Conclui-se, no geral, para a maior parte das variáveis analisadas, que a água tratada se enquadrou dentro dos limites e padrões estabelecidos pela Resolução CONAMA 357/2005 para águas doces de classe 2 (BRASIL, 2005). Contudo, em função dos dados obtidos, não se pode enquadrar totalmente o efluente tratado nos padrões e limites estabelecidos pela resolução, embora seja esperado que, com a estabilização do sistema e um manejo adequado, o efluente consiga alcançar as características exigidas para águas doces de classe 2 .

\section{RECOMENDAÇÕES}

Para um melhor funcionamento do sistema combinado de alagados construídos e conseqüente melhoria da qualidade das águas, algumas recomendações são sugeridas:

- É necessário que haja um manejo adequado no canal de macrófitas com retirada de uma parte das plantas aquáticas que cobrem totalmente o sistema. Desta forma, serão liberadas superfícies livres para incidência de raios ultravioleta 
(reduzir os coliformes) e a difusão do oxigênio atmosférico para a água. Com o aumento de oxigênio na água serão otimizados os processos aeróbios de remoção: decomposição, nitrificação, oxidação de metais, precipitação e coprecipitação com hidróxidos de ferro e manganês. Recomenda-se que apenas $80 \%$ do canal permaneça coberto por macrófitas.

- Colheitas periódicas das macrófitas, tanto do canal de MAFE quanto dos solos filtrantes são também importantes para evitar que os nutrientes retirados do sistema voltem para coluna d’água após a decomposição das plantas.

- O manejo adequado dos solos filtrantes, fazendo a alternância do funcionamento das células de 10 a 15 dias é necessário para evitar a colmatação do solo e permitir a aeração do sistema DHS. Durante os períodos de aplicação do efluente, ocorre a saída do ar do solo, enquanto que no período de pousio e drenagem, o ar atmosférico é movido para dentro dos espaços intersticiais do solo, aumentando assim a sua oxigenação. Logo, as condições alternadas de redução e oxigenação no substrato estimulam as seqüências de nitrificação/desnitrificação e a adsorção do fósforo.

- A vazão de entrada do sistema deve ser aumentada para 0,5L.s ${ }^{-1}$ (conforme previsto no projeto inicial) para que o sistema funcione com o tempo de retenção hidráulico do canal e taxa de aplicação dos solos para qual ele foi projetado.

- Seria interessante isolar o sistema com grades, de forma a impedir a visita dos macacos, quatis e guaxinins do parque às células de solos filtrantes. Com isso se espera uma maior remoção do sistema com relação as variáveis: cor, turbidez, sólidos totais, coliformes totais e termotolerantes.

- A baixa concentração de oxigênio dissolvido na água após a saída dos solos filtrantes pode ser resolvida com a implantação de estratégias simples na saída do sistema, como por exemplo, cascatas e corredeiras. 
- Espera-se que com essas recomendações, maiores taxas de remoção sejam alcançadas e as águas da lagoa do Parque Ecológico do Tietê sejam enquadradas nas águas de classe 2 da Resolução CONAMA 357/2005 (BRASIL, 2005), podendo assim serem utilizadas, não só para abastecimento do lago de criação de jacarés, mas também para irrigação de hortaliças, plantas frutíferas, jardins e campos de esporte e lazer do próprio parque.

- Sugere-se a realização de novas coletas, no período de um ano, com coletas quinzenais ou mensais para análise das variáveis: oxigênio dissolvido, $\mathrm{pH}, \mathrm{DBO}$, DQO, cor, turbidez, sólidos totais, nutrientes (fósforo total e nitrogênio amoniacal), metais (ferro total e chumbo), fenol e coliformes totais e termotolerantes. Dentre estas variáveis estão as consideradas de grande importância para a caracterização do sistema e as que não atenderam os limites estabelecidos pelo CONAMA 357/05 (BRASIL, 2005). Através deste monitoramento será possível observar alterações na qualidade da água tratada nas diferentes estações do ano além de compreender o funcionamento do sistema. 


\section{REFERÊNCIAS BIBLIOGRÁFICAS}

AMERICAN PUBLIC HEALTH ASSOCIATION (1998). Standard Methods for the Examination of Water and Wastewater. 20Ed. Washington: American Public Health Association, AWWA, WPCF, 1569p.

ANDRADE, A.A.S. (2005). Análise da eficiência da várzea do Ribeirão Parelheiros na melhoria de qualidade das águas que afluem à represa do Guarapiranga, São Paulo. Dissertação (Mestrado), Escola de Engenharia de São Carlos, Universidade de São Paulo, São Carlos, 2005, 75p.

ANJOS, J.A.S.A. (2003). Avaliação da eficiência de uma zona alagadiça (wetland) no controle da poluição por metais pesados: o caso da Plumbum em Santo Amaro da Purificação/BA. Tese (Doutorado). Escola Politécnica, Universidade de São Paulo, São Carlos, 2003, 327p. Disponível em: $<$ http://www.teses.usp.br/teses/disponiveis/3/3134/tde-28042004-094552/> Acesso em: 10 dez. 2005.

BASTIAN, R.K; HAMMER, D.A. (1993). The Use of Constructed Wetlands for Wastewater Treatment and Recycling In: MOSHIRI, A. (Ed) Constructed Wetlands for Water Quality Improvement. Boca Raton: Lewish Publishers. Cap.5, p.59-68

BENASSI, R.F. (no prelo). Avaliação da Capacidade Redutora de Carga de um Sistema de Áreas Alagadas Naturais em Microbacia do Ribeira do Iguape, SP. Tese (Doutorado). Escola de Engenharia de São Carlos, Universidade de São Paulo, São Carlos.

BECCATO, M.A.B. (2004). Elaboração Participativa de uma Proposta de Reestruturação do Sistema de Tratamento de Esgoto da Comunidade do Marujá Parque Estadual da Ilha do Cardoso/SP. Dissertação (Mestrado). Escola de Engenharia de São Carlos, Universidade de São Paulo, São Carlos, 2004, 292p.

BILLORE, S.K; SINGH, N; RAM, H.K; SHARMA, J.K; SINGH, V.P; NELSON, R.M; DASS, P. (2000). Treatment performance of a molasses based distillery effluent in a biofilm-reed bed constructed wetland in Central India. In: INTERNATIONAL 
CONFERENCE ON WETLAND SYSTEMS FOR WATER POLLUTION CONTROL, 7., 2000, Lake Buena Vista. Proceedings. Lake Buena Vista: IWA. v.3, p.1227-1237.

BORGES, K. B; TAUK-TORNISIELO, S.M; DOMINGOS, R.N; ANGELIS, D.F. (2003). Tratamento de Águas Contaminadas com Microorganismos por Leitos Cultivados. Revista Arquivos do Instituto Biológico, v.70, n. 3, p.799-802.

BRASIL (2004). Portaria MS N $\mathrm{N}^{\mathrm{O}}$ 518/2004. Estabelece os procedimentos e responsabilidades relativos ao controle e vigilância da qualidade da água para consumo humano e seu padrão de potabilidade e dá outras providências. Diário Oficial de República Federativa do Brasil. Brasília. Disponível em: <http://www.mma.gov.br/port/conama/> Acesso em: 29 mar. 2005.

BRASIL (2005). Resolução CONAMA 357/2005. Dispõe sobre a classificação dos corpos de água e diretrizes ambientais para seu enquadramento, bem como estabelece as condições e padrões de lançamento de efluentes, e dá outras providências. Diário Oficial de República Federativa do Brasil. Brasília. Disponível em: $<$ http://www.mma.gov.br/port/conama/> Acesso em: 29 mar. 2005.

BRIX, H. (1993). Wastewater Treatment in Constructed Wetlands System: Design, Removal Processes and Treatment Performance. In: MOSHIRI, A. (Ed) Constructed Wetlands for Water Quality Improvement. Boca Raton: Lewish Publishers. Cap.2, p.9-22.

. (1994). Constructed Wetlands for Municipal Wastewater Treatment in Europe. In: MITSH, W. J. (Ed) Global Wetlands: Old World and New. New York: Elsevier Science. p. 325-333

CALIJURI, M. C. e BUBEL, A. P. M. (2006). Conceituação de Microbacias. In: LIMA, W. P. \& ZAKIA, M. J. B (eds) Manejo Ambiental de Florestas Plantadas: Operacionalizando o Conceito de Microbacia como Unidade de Planejamento. São Carlos: RIMA. Cap. 4, p.45-60.

CAMPOS, J. C; FERREIRA, J.A; MANNARINO, C.F; SILVA, H.R; BORBA, S.M.P. (2002). Tratamento do Chorume do Aterro Sanitário de Piraí (RJ) utilizando Wetlands. In: SIMPÓSIO ÍTALO-BRASILEIRO DE ENGENHARIA SANITÁRIA E AMBIENTAL, 6., Vitória. Proceedings. Vitória: ABES. III-019, 12p. 
CECCONELLO, M.C. (2005). Pós-tratamento de lixiviados de aterro de resíduos sólidos urbanos utilizando leitos cultivados. Dissertação (Mestrado) Faculdade de Engenharia e Arquitetura, Universidade de Passo Fundo, Passo Fundo, 2005, 149 p. Disponível em: <http://www.ppgeng.upf.br/download/2003CatianeCecconello.pdf > Acesso em: 13 jul. 2005.

CHENG, S; GROSSE, W; KARRENBROCK, F; THOENNESSEN, M. (2002). Efficiency of constructed wetlands in decontamination of water polluted by heavy metals. Ecological Engineering, v.18, p. 317-325.

COOPER, P. (1998). A review of the design and performance of vertical flow and hybrid reed bed treatment systems. In: INTERNATIONAL CONFERENCE ON WETLANDS SYSTEMS FOR WATER POLLUTION CONTROL, 6., 1998, Águas de São Pedro, Proceedings. Águas de São Pedro: UNESP, IWA. p.229-242.

COSTELlO, C. J. (1989). Wetlands Treatment of Dairy Animal Wastes in Irish Drumlin Landscape In: HAMMER, D. A. (Ed) Constructed Wetland for Waste Water Treatment: Municipal, Industrial e Agricultural. Michigan: Lewis Publishers, INC. Cap. 40e, p. 702-709.

DUNNE, E.J; CUlletON, N; O`DONOVAN, G; HARRINGTON, R; DALY, K. (2005). Phosphorus retention and sorption by constructed wetland soils in Southeast Ireland. Water Research, v.39, p. 4355-4362.

EGER, P; MELCHERT, G; ANTONSON, D; WAGNER, J. (1993). The use of Wetland Treatment to Remove Trace Metals from Mine Drainage. In: MOSHIRI, A. (Ed) Constructed Wetlands for Water Quality Improvement. Boca Raton: Lewish Publishers. Cap.17, p. 171-178.

ELIAS, J.M. (2003). Análise da Eficiência Global do Sistema de "Wetlands" Construído na Estação de Tratamento de Água para Abastecimento Público no Município de Analândia. Dissertação (Mestrado) Centro de Estudos Ambientais, Universidade Estadual Paulista, Rio Claro, 2003, 214 p.

ESTEVES, F.(1988). Fundamentos de Limnologia. Rio de Janeiro: FINEP, 575p. 
FAULKNER, S.P; RICHARDSON, C.J. (1989). Physical and Chemical Characteristics of Freshwater Wetland Soils. In: HAMMER, D.A. (Ed) Constructed Wetlands for Wastewater Treatment: municipal, industrial and agricultural. Michigan: Lewis Publishers, INC. Cap. 27, p. 319-352.

FIGUEIROA, F.E.V. (1996). Avaliação Econômica de Ambientes Naturais. O Caso das Áreas Alagadas: uma proposta para a Represa do Lobo (Broa). Itirapina-SP. Dissertação (Mestrado), Escola de Engenharia de São Carlos, Universidade de São Paulo, São Carlos, 1996, 143p.

FERREIRA, J.A; GIORDANA, G; RITTER, E; ROSSO, T.C.A; CAMPOS, J.C; LIMA, P.Z.M. (2001). Uma Revisão das Técnicas de Tratamento de Chorume e a Realidade do Estado do Rio de Janeiro. In: CONGRESSO BRASILEIRO DE ENGENHARIA SANITÁRIA E AMBIENTAL, 21., 2001, João Pessoa. Proceedings. João Pessoa: ABES. III-108, 9p.

FUNDAÇÃO BRASILEIRA PARA O DESENVOLVIMENTO SUSTENTÁVEL FBDS (2004). Relatório Final do Centro de Educação e Difusão de Tecnologias Ambientais. Termo de Contrato CSS n. 18320/02.

GERSBERG, R. M; GEARHEART, R.A; IVES, M. (1989). Pathogen Removal in Constructed Wetlands. In: HAMMER, D. A. (Ed) Constructed Wetland for Waste Water Treatment: Municipal, Industrial e Agricultural. Michigan: Lewis Publishers, INC. Cap. 35, p. 431-445.

GERSBERG, R.M; STEPHEN, R.L; BRENNER, R \& ELKINS, B.V. (1989). Integrated Wastewater Treatment Using Artificial Wetlands: A gravel Marsh Case Study. In: HAMMER, D. A. (Ed) Constructed Wetland for Waste Water Treatment: Municipal, Industrial e Agricultural. Michigan: Lewis Publishers, INC. Cap. 10, p. 145-152.

GIOVANINNI, S.G.T; MARQUES, D.M.L.M. (1998). Establishment of Three Emergent Macrophytes Under Different Water Regimes. In: INTERNATIONAL CONFERENCE ON WETLANDS SYSTEMS FOR WATER POLLUTION CONTROL, 6., 1998, Águas de São Pedro. Proceedings. Águas de São Pedro: UNESP, IWA. p.95 
HAMMER. D.A. (1993). Designing Constructed Wetlands Systems to Treat Agricultural Nonpoint Source Pollution. In: OLSON, R.K. (Ed) Created and Natural Wetlands for Controlling Nonpoint Source Pollution. Boca Raton: C.K. Smoley. Cap.4, p.71-111.

HAMMER, D.A.; BASTIAN, R.K. (1989). Wetlands Ecosystems: Natural Water Purifiers? In: HAMMER, D.A. (Ed) Constructed Wetlands for Wastewater Treatment: municipal, industrial and agricultural. Michigan: Lewis Publishers, INC. Cap. 2, p. 5-19.

HAMMER, D.A; PULLIN, B.P; MCMURRY, D.K; LEE, J.W. (1993). Testing Color Removal from Pulp Mill Wastewaters with Constructed Wetlands. In: MOSHIRI, A. (Ed) Constructed Wetlands for Water Quality Improvement. Boca Raton: Lewish Publishers. Cap.48, p. 449-452.

HEDIN, R.S; HAMMACK, R; HYMAN, D. (1989) Potential Importance of Sulfate Reduction Processes in Wetlands Constructed to Treat Mine Drainage. In: HAMMER, D.A. (Ed) Constructed Wetlands for Wastewater Treatment: municipal, industrial and agricultural. Michigan: Lewis Publishers, INC. Cap. 38b, p. 508-14.

HOWARD, E. A; EMERICK, J.C; WILDEMAN, T.R. (1989). Design and Construction of a Research Site for Passive Mine Drainage Treatment in Idaho Springs, Colorado. In: HAMMER, D.A. (Ed) Constructed Wetlands for Wastewater Treatment: municipal, industrial and agricultural. Michigan: Lewis Publishers, INC. Cap. 42b, p. 761-764.

HUETT, D.O; MORRIS, S.G; SMITH, G; HUNT, N. (2005). Nitrogen and phosphorus removal from plant nursery runoff in vegetated and unvegetated subsurface flow wetlands. Water Research, v.39, p. 3259-3272.

HUNTER, R.; BIRKBECK, A. E.; COOMBS, G. (1993). Innovative Marsh Treatment For Control of Leachate and Fish Hatchery Wastewaters. In: MOSHIRI, A. (Ed) Constructed Wetlands for Water Quality Improvement. Boca Raton: Lewish Publishers. Cap.52, p. 477-484.

INSTITUTO DE ECOLOGIA APLICADA LTDA - IEA (1997). Relatório técnico. 
JI, G; SUN, T; ZHOU, Q; SUI, X; CHANG, S; LI, P. (2002). Constructed subsurface flow wetland for treating heavy oil-produced water of Liaohe Oilfield in China. Ecological Engineering, v.18, p. 459-465.

JUCÁ, J.F.T. (2003). Disposição Final dos Resíduos Sólidos Urbanos no Brasil. IN: 50 CONGRESSO BRASILEIRO DE GEOTECNIA AMBIENTAL, Porto Alegre, 2003. Disponível em: <http: // www. grs - ufpe. com. br / downloads / publicacoes /regeo 2003- juca1.pdf > Acesso em: 22 jan. 2004.

JUNK, W.J. (1980). Áreas inundáveis - Um desafio para Limnologia. Acta Amazônica, v.10, n.4, p.775-795.

KADLEC, R.H (1994). Wetlands for Water Polishing: Free Water Surface Wetlands. In. MITSH, W. J. (Org) Global Wetlands: Old World and New. New York: Elsevier Science, 1994. p. 411- 420

KADLEC, R.H. (1997) An autobiotic wetland phosphorus removal model. Ecological Engineering, v. 8, n. 2, p. 145-72.

KADLEC, R.H. Chemical, physical and biological cycles in treatment wetlands. In: INTERNATIONAL CONFERENCE ON WETLANDS SYSTEMS FOR WATER POllution CONTROL, 6., Águas de São Pedro, 1998. Proceedings. Águas de São Pedro: UNESP, IWA, 1998. p.42-53.

KADLEC, R.H; KNIGHT, R.L. (1996). Treatment Wetlands. Boca Raton: Lewish Publishers, 893 p.

KADLEC, R. H; KNIGHT, R. L; VYMAZAL, J; BRIX, H; COOPER, P; HABERL, R. (2000). Constructed Wetlands for Pollution Control: process, performance, design and operation - Scientific and Technical Report, London: IWA Publishing, n. 8, $156 \mathrm{p}$.

KNIGHT, R.L; RUBLE, R.W; KADLEC, R.H; REDD, S. (1993). Wetlands for Wastewater Treatment: performance database. In: MOSHIRI, A. (Ed) Constructed Wetlands for Water Quality Improvement. Boca Raton: Lewish Publishers. Cap.4, p. 35-58. 
KOLTEC CONSULTORES ASSOCIADOS S/S LTDA (2004). Projeto de implantação do sistema piloto através da utilização de técnicas de wetlands construídos para o tratamento do efluente industrial da fábrica de Pederneiras/SP da Burns Philp Brasil Indústria e Comércio de Alimentos. 16 p.

KYAMBADDE, J; KANSIIME, F; DALHAMMAR, G. (2005). Nitrogen and phosphorus removal in substrate-free pilot constructed wetland with horizontal surface flow in Uganda. Water, Air, and Soil Pollution, v. 165, p.37-59.

LAUTENSCHLAGER, S.R. (2001). Modelagem do desempenho de wetlands construídas. Dissertação (Mestrado). Escola Politécnica, Universidade de São Paulo, São Paulo, 2001, 90p.

LEITÃO, T.E; BARBOSA, A.E; HENRIQUES, M.J; IRÃVAKO, V.M; MENEZES, J.T.M. (2006). Avaliação e Gestão Ambiental de Águas de Escorrência de Estradas. Disponível em: < http://www.inag.pt/inag2004/port/a_intervencao/d_hidrico/pdf/ estudos_amb/3-relatAnexos2004.pdf >. Acesso em: 01 ago. 2006.

LOPES-FERREIRA, C.M. (2000). Estudo de uma área alagada do rio Atibaia visando à elaboração de proposta de manejo para melhoria da qualidade da água no reservatório de Salto Grande (Americana, SP). Tese (Doutorado). Escola de Engenharia de São Carlos, Universidade de São Paulo, São Carlos, 2000, 145p.

MANFRINATO, E.S. (1989). Avaliação do método edafo-fitopedológico para tratamento preliminar de águas. Tese (Doutorado), Escola Superior de Agricultura “Luiz de Queiroz”, Universidade de São Paulo, Piracicaba, 1989, 98p.

MARQUES, D.M. (1999). Terras úmidas construídas de fluxo subsuperficial. In: CAMPOS, J.R (Coord.) Tratamento de esgotos sanitários por processo anaeróbio e disposição controlada no solo. Rio de Janeiro: ABES. Cap. 15, p.409-435.

MEIORIN, E. C. (1989). Urban Runnoff Treatment in a Fresh/Brackish Water Marsh in Fremont, California. In: HAMMER, D. A. (Ed) Constructed Wetland for Waste Water Treatment: Municipal, Industrial e Agricultural. Michigan: Lewis Publishers, INC. Cap. 40b, p. 677-685. 
MINISTÉRIO DA CIÊNCIA E TECNOLOGIA - MCT (2005). Áreas Alagáveis. Disponível em: $<$ http://www.ftp.mct.gov.br/Temas/meioambiente/defaulat.asp $>$. Acesso em: 20 mai. 2005.

NEWMAN, J.M; CLAUSEN, J.C; NEAFSEY, J.A. (2000). Seasonal performance of wetland constructed to process dairy milkhouse wastewater in Connecticut. Ecological Engineering, v.14, p.181-198.

NETTER, R. (1993). The Purification Efficiency of Planted Soil Filter. In: MOSHIRI, A. (Ed) Constructed Wetlands for Water Quality Improvement. Boca Raton: Lewish Publishers. Cap.25, p. 249-254.

NOGUEIRA, S.F. (2003). Balanço de nutrientes e avaliação de parâmetros biogeoquímicos em áreas alagadas construídas para o tratamento de esgoto. Dissertação (Mestrado), Centro de Energia Nuclear na Agricultura, Universidade de São Paulo, Piracicaba, 2003, 137p.

OBARSKA-PEMPKOWIAK, H. (2000). Retention of selected heavy metals: Cd, Cu, $\mathrm{Pb}$ in a hybrid wetland system. In: INTERNATIONAL CONFERENCE ON WETLAND SYSTEMS FOR WATER POLLUTION CONTROL, 7., Lake Buna Vista. Proceedings. Lake Buena Vista: IWA. v.3, p.1285-1308.

OLIVEIRA, M.A; BARRETO, A.J; ROQUETE-PINTO, C.L; PEREIRA, R.G. (1998). Utilization of Aquatic Biomass to Energy Production. In: INTERNATIONAL CONFERENCE ON WETLANDS SYSTEMS FOR WATER POLLUTION CONTROL, 6., 1998, Águas de São Pedro, Proceedings. Águas de São Pedro: UNESP, IWA. p.152.

PADUA, H.B. (2004). Nitrogênio In: Água. Parte V. Disponível em: $<$ http://www.ecoviagem.com.br/fiquepordentro/def_fiquepordentro.asp?codigo $=8490>$. Acesso em: 15 abr. 2006.

PARESCHI, D.C. (2004). Caracterização da fauna de Rotifera em área alagada construída para tratamento de esgoto doméstico - Piracicaba (SP). Dissertação (Mestrado), Escola de Engenharia de São Carlos, Universidade de São Paulo, São Carlos, 2004, 168p. 
PHILLIPHI, L.S; COSTA, R.H.R. (1998). Domestic Effluent Treatment Through Integrated System of Septic Tank and Root Zone. In: INTERNATIONAL CONFERENCE ON WETLANDS SYSTEMS FOR WATER POLLUTION CONTROL, 6., 1998, Águas de São Pedro, Proceedings. Águas de São Pedro: UNESP, IWA. p. 50.

REED, S.C; CRITES, R.W; MIDDLEBROOKS, E. J. (1995). Wetlands Systems In: REED, S.C (Ed) Natural System for Waste Management and Treatment, 2 ed. New York: McGraw-Hill, INC. Cap. 6, p.173 - 284.

REDDY; K.R; D`ANGELO, E.M. (1994). Soil process regulating water quality in wetlands. In: MITSH, W. J. (Org) Global Wetlands: Old World and New. New York: Elsevier Science, 1994. p. 309-324.

ROQUETE-PINTO, C.L. (1998). Utilization of water hyacinth for zinc removal and environmental monitoring of natural waters. In: INTERNATIONAL CONFERENCE ON WETLANDS SYSTEMS FOR WATER POLLUTION CONTROL, 6., 1998, Águas de São Pedro, Proceedings. Águas de São Pedro: UNESP, IWA. p.151.

ROQUETE-PINTO, C.L; LIMA, R.M. (1998). Utilization of water hyacinth to obtain protein for animal fed. In: INTERNATIONAL CONFERENCE ON WETLANDS SYSTEMS FOR WATER POLLUTION CONTROL, 6., 1998, Águas de São Pedro, Proceedings. Águas de São Pedro: UNESP, IWA.p.111.

SALATI, E. (1998). Controle de qualidade de águas através de sistemas de wetlands construídas. (Relatório) Brasília: CNPq.

SALATI, E. (2000). Utilização de Sistemas de Wetlands Construídas para Tratamento de Águas. Relatório técnico para o Programa de Pós Graduação em Ciências da Engenharia Ambiental da EESC. São Carlos. 36 p.

SALATI, ENEAS; SALATI FILHO, E; TAUK-TORNISIELO, S.M; BREGA, D.F; BOMBONATO, C.J. (1999). Use of the HDS System (Hydric Depuration with Soils) Associated to other Constructed Wetlands Techniques for Public Water Supply. Water Science and Technology, v.40, n.3, p.203-210. 
SALATI FILHO, E; MANFRINATO, E. S.; SALATI, E. (1996). Secondary and Tertiary Treatment of Urban Sewage Utilizing the HDS System With Upflow Transport. In: $5^{\text {TH }}$ INTERNATIONAL CONFERENCE ON WETLAND SYSTEMS FOR WATER POllution CONTROL, 1996, Vienna. Proceedings. Vienna: IAW. v.1, p.VI/3-1-VI/3-6.

SALATI FILHO, E; SALATI, ENEIDA; SALATI, ENEAS (1999). Wetland Projects Developed in Brazil. Water Science and Technology, v.40, n.3, p.19-25.

SILVERMAN, G.S. (1989). Development of an Urban Runnoff Treatment Wetlands in Fremont, California. In: HAMMER, D. A. (Ed) Constructed Wetland for Waste Water Treatment: Municipal, Industrial e Agricultural. Michigan: Lewis Publishers, INC. Cap. 40a, p. 669-676.

SMITH, A.J. (1989). A Perspective. In: HAMMER, D.A. (Ed) Constructed Wetlands for Wastewater Treatment: municipal, industrial and agricultural. Michigan: Lewis Publishers, INC. Cap. 1, p. 3-4.

SOLANO, M. L.; SORIANO, P; CIRIA, M. P. (2004). Constructed Wetlands as a Sustainable Solution for Wastewater Treatment in Small Villages. Biosystems Engineering, v.87, n.1, p. 109-118.

SOUSA, J.T; VAN HAANDEL, A.C; COSENTINO, P.R.S; GUIMARÃES, A.V.A. (2000). Pós-Tratamento de Efluente de Reator UASB Utilizando Sistemas "Wetlands" Construídos. Revista Brasileira de Engenharia Agrícola e Ambiental, v.4, n.1, p. 8791.

STEINER, G.R; COMBS, D.W. (1993). Small Constructed Wetlands Systems for Domestic Wastewater Treatment and Their Performance. In: MOSHIRI, A. (Ed) Constructed Wetlands for Water Quality Improvement. Boca Raton: Lewis Publishers, INC. Cap.54, p. 491-498.

SURFACE, J.M; PEVERLY, J.H; STEENHUIS, T.S; SANFORD, W.E. (1993). Effect of Season, Substrate Composition, and Plant Growth on Landfill Leachate Treatment in Constructed Wetland. In: MOSHIRI, A. (Ed) Constructed Wetlands for Water Quality Improvement. Boca Raton: Lewis Publishers, INC. Cap.50, p. 461-472. 
THUT, R.N. (1989). Utilization of Artificial Marshes for Treatment of Pulp Mill Effluents. In: HAMMER, D.A. (Ed) Constructed Wetlands for Wastewater Treatment: municipal, industrial and agricultural. Michigan: Lewis Publishers, INC, Cap. 19, p. 239-244.

U.S. ENVIRONMENTAL PROTECTION AGENCY - USEPA (2005). Wetlands. Disponível em: <http:// www.epa.gov/owow/wetlands/>. Acesso em: 20 fev. 2005.

VALENTIM, M.A.A. (2003) Desempenho de Leitos Cultivados (Constructed Wetlands) para Tratamento de Esgoto: contribuições para concepção e operação. Tese (Doutorado). Faculdade de Engenharia Agrícola, Universidade Estadual de Campinas, Campinas, 2003, 209p.

VYMAZAL, J. (1998). Types of Constructed Wetlands for Wastewater Treatment: ecology and use of wetlands. In: INTERNATIONAL CONFERENCE ON WETLANDS SYSTEMS FOR WATER POLLUTION CONTROL, 6., 1998, Águas de São Pedro, Proceedings. Águas de São Pedro: UNESP, IWA. p.2.

VON SPERLING, M. (1996). Introdução à qualidade das águas e ao tratamento de esgotos. 2.Ed, Belo Horizonte: DESA/UFMG, 243p.

VRHOVSEK, D; KUKANJA, V; BULC, T. (1996). Constructed Wetland (CW) for Industrial Waste Water Treatment. Water Research, v.30, n.10, p. 2287-2292.

WATSON, J.T; REED, S.C; KADLEC, R.H; KNIGHT, R.L; WHITEHOUSE, A.E. (1989). Performance Expectations and Loading Rates for Constructed wetlands. In: HAMMER, D.A. (Ed) Constructed Wetlands for Wastewater Treatment: municipal, industrial and agricultural. Michigan: Lewis Publishers, INC. Cap. 27, p. 319-352.

WETZEL, R.G. (1993). Constructed Wetlands: Scientifics Foundations are Critical. In: MOSHIRI, A. (Ed) Constructed Wetlands for Water Quality Improvement. Boca Raton: Lewish Publishers, INC. Cap.1, p. 3-7

WITTHAR, S. R. (1993). Wetland Water Treatment Systems. In: MOSHIRI, A. (Ed) Constructed Wetlands for Water Quality Improvement. Boca Raton: Lewish Publishers, INC. Cap.14, p. 147-155. 
APÊNDICE 
APÊNDICE A - Variação dos valores limnológicos obtidos durante o período de estudo de 2004 e 2005 comparando-se com os padrões e limites estabelecidos para águas doces de classe 2 (CONAMA 357/2005).

Tabelas 35 a 42 
Tabela 35: Variação dos valores da concentração das variáveis durante os meses de fevereiro e março de 2004.

\begin{tabular}{|c|c|c|c|c|c|c|c|c|}
\hline \multicolumn{9}{|c|}{ CONCENTRAÇÃO DAS VARIÁVEIS 2004} \\
\hline \multirow[b]{2}{*}{ VARIÁVEIS } & \multirow[b]{2}{*}{ UNIDADES } & \multicolumn{3}{|c|}{ FEVEREIRO } & \multicolumn{3}{|c|}{ MARÇO } & \multirow{2}{*}{$\begin{array}{l}\text { CONAMA } \\
357 / 2005 \\
\text { Classe } 2\end{array}$} \\
\hline & & $\begin{array}{c}\text { P1 } \\
\text { Entrada } \\
\text { Sistema }\end{array}$ & $\begin{array}{c}\text { P2 } \\
\text { Saída } \\
\text { MAFE }\end{array}$ & $\begin{array}{c}\text { P3 } \\
\text { Saída } \\
\text { Sistema }\end{array}$ & \begin{tabular}{|c|} 
P1 \\
Entrada \\
Sistema \\
\end{tabular} & \begin{tabular}{|c|} 
P2 \\
Saída \\
MAFE \\
\end{tabular} & $\begin{array}{c}\text { P3 } \\
\text { Saída } \\
\text { Sistema }\end{array}$ & \\
\hline Temp. do ar & ${ }^{\circ} \mathrm{C}$ & 21 & 21 & 21 & 24 & 24 & 24 & - \\
\hline Temp. da água & ${ }^{\circ} \mathrm{C}$ & 22 & 22 & 21 & 23,5 & 24 & 23,5 & - \\
\hline Oxigênio Diss. & $\mathrm{mg} \mathrm{O}_{2} / \mathrm{L}$ & 6,37 & 6,61 & 6,75 & 6,38 & 7,12 & $<0,20$ & $\geq 5$ \\
\hline pH & - & 7,1 & 6,9 & 7,0 & 7,6 & 7,3 & 6,4 & 6 a 9 \\
\hline Alcalinidade & $\mathrm{mg} \mathrm{CaCO}_{3} / \mathrm{L}$ & 36,3 & 25,7 & 25,9 & 43,7 & 36,0 & 32,4 & - \\
\hline Dureza & $\mathrm{mg} \mathrm{CaCO}_{3} / \mathrm{L}$ & 34,1 & 28,2 & 24,6 & 40,2 & 36,6 & 32,5 & - \\
\hline Cloreto & $\mathrm{mg} \mathrm{Cl} / \mathrm{L}$ & 26,4 & 18,8 & 18,7 & 24,5 & 22,1 & 21,8 & 250 \\
\hline Sulfato & $\mathrm{mg} \mathrm{SO}_{4} / \mathrm{L}$ & 13,6 & 9,7 & 9,7 & 13 & 12 & 8 & 250 \\
\hline Condutividade & $\mu \mathrm{mho} / \mathrm{cm}$ & 184 & 138 & 137 & 226 & 184 & 184 & - \\
\hline Cor & UC & 175 & 60 & 50 & 130 & 60 & 110 & 75 \\
\hline Turbidez & UNT & 50,9 & 11,1 & 6,0 & 26,8 & 10,9 & 25,5 & 100 \\
\hline Sol. Totais & $\mathrm{mg} / \mathrm{L}$ & - & - & - & 194 & 164 & 176 & - \\
\hline DBO & $\mathrm{mg} \mathrm{O}_{2} / \mathrm{L}$ & 14,0 & 10,0 & 7,0 & 15,2 & 9,8 & 8,1 & $\leq 5$ \\
\hline DQO & $\mathrm{mg} \mathrm{O}_{2} / \mathrm{L}$ & 76 & 66 & 56 & 73 & 64 & 44 & - \\
\hline Fósforo Total & $\mathrm{mg} \mathrm{P/L}$ & 0,128 & 0,031 & 0,058 & 0,087 & 0,053 & 0,049 & 0,05 \\
\hline N-Albuminóide & $\mathrm{mg} \mathrm{N} / \mathrm{L}$ & 1,87 & 1,15 & 0,98 & 1,53 & 0,97 & 0,89 & - \\
\hline N-Amoniacal & $\mathrm{mg} \mathrm{N} / \mathrm{L}$ & 0,28 & 0,18 & 0,12 & 0,98 & 0,11 & 0,12 & $3,7 \mathrm{pH} \leq 7,5$ \\
\hline Nitrato & $\mathrm{mg} \mathrm{N} / \mathrm{L}$ & $<0,10$ & $<0,10$ & $<0,10$ & $<0,10$ & $<0,10$ & $<0,10$ & 10,0 \\
\hline Nitrito & $\mathrm{mg} \mathrm{N} / \mathrm{L}$ & $<0,001$ & $<0,001$ & $<0,001$ & 0,0031 & $<0,001$ & 0,0005 & 1,0 \\
\hline Bário & $\mathrm{mg} \mathrm{Ba} / \mathrm{L}$ & $<0,05$ & 0,05 & $<0,05$ & $<0,05$ & 0,05 & $<0,05$ & 0,7 \\
\hline Cádmio & $\mathrm{mg} \mathrm{Cd} / \mathrm{L}$ & $<0,0005$ & 0,0006 & $<0,0005$ & 0,0008 & 0,0009 & 0,0006 & 0,001 \\
\hline Chumbo & $\mathrm{mg} \mathrm{Pb/L}$ & $<0,005$ & $<0,005$ & $<0,005$ & $<0,005$ & $<0,005$ & $<0,005$ & 0,01 \\
\hline Cobre & $\mathrm{mg} \mathrm{Cu} / \mathrm{L}$ & $<0,02$ & $<0,02$ & $<0,02$ & $<0,02$ & $<0,02$ & $<0,02$ & - \\
\hline Cromo & $\mathrm{mg} \mathrm{Cr} / \mathrm{L}$ & $<0,003$ & $<0,003$ & $<0,003$ & $<0,003$ & $<0,003$ & $<0,003$ & 0,05 \\
\hline Ferro Total & $\mathrm{mg} \mathrm{Fe} / \mathrm{L}$ & 0,89 & 0,45 & 0,21 & 0,56 & 0,31 & 2,36 & - \\
\hline Manganês Total & $\mathrm{mg} \mathrm{Mn/L}$ & 0,12 & 0,03 & $<0,02$ & 0,06 & 0,03 & 0,07 & 0,1 \\
\hline Mercúrio & $\mathrm{Mg} \mathrm{Hg} / \mathrm{L}$ & $<0,0005$ & $<0,0005$ & $<0,0005$ & $<0,0005$ & $<0,0005$ & $<0,0005$ & 0,0002 \\
\hline Prata & $\mathrm{mg} \mathrm{Ag} / \mathrm{L}$ & $<0,001$ & $<0,001$ & $<0,001$ & 0,001 & $<0,001$ & $<0,001$ & 0,01 \\
\hline Selênio & $\mathrm{Mg} \mathrm{Se} / \mathrm{L}$ & 0,001 & 0,001 & 0,001 & $<0,001$ & $<0,001$ & $<0,001$ & 0,01 \\
\hline Zinco & $\mathrm{mg} Z \mathrm{n} / \mathrm{L}$ & $<0,05$ & $<0,05$ & $<0,05$ & $<0,05$ & $<0,05$ & $<0,05$ & 0,18 \\
\hline Coli. Totais & $\mathrm{NMP} / 100 \mathrm{~mL}$ & 43.520 & 77.010 & 29.090 & 32.820 & 198.630 & 98.040 & 5.000 \\
\hline $\begin{array}{l}\text { Coli. } \\
\text { Termotolerantes }\end{array}$ & $\mathrm{NMP} / 100 \mathrm{~mL}$ & 850 & 155 & 3 & 26 & 20 & 630 & 1000 \\
\hline
\end{tabular}


Tabela 36: Variação dos valores da concentração das variáveis durante os meses de junho e julho de 2004.

\begin{tabular}{|c|c|c|c|c|c|c|c|c|}
\hline \multicolumn{8}{|c|}{ CONCENTRAÇÃO DAS VARIÁVEIS 2004} & \multirow{3}{*}{$\begin{array}{l}\text { CONAMA } \\
357 / 2005 \\
\text { Classe } 2\end{array}$} \\
\hline \multirow[b]{2}{*}{ VARIÁVEIS } & \multirow[b]{2}{*}{ UNIDADES } & \multicolumn{3}{|c|}{ JUNHO } & \multicolumn{3}{|c|}{ JULHO } & \\
\hline & & $\begin{array}{c}\text { P1 } \\
\text { Entrada } \\
\text { Sistema }\end{array}$ & $\begin{array}{c}\text { P2 } \\
\text { Saída } \\
\text { MAFE }\end{array}$ & $\begin{array}{c}\text { P3 } \\
\text { Saída } \\
\text { Sistema }\end{array}$ & $\begin{array}{c}\text { P1 } \\
\text { Entrada } \\
\text { Sistema }\end{array}$ & $\begin{array}{c}\text { P2 } \\
\text { Saída } \\
\text { MAFE }\end{array}$ & $\begin{array}{c}\text { P3 } \\
\text { Saída } \\
\text { Sistema }\end{array}$ & \\
\hline Temp. do ar & ${ }^{\circ} \mathrm{C}$ & 13 & 13 & 13 & 19 & 19 & 19 & - \\
\hline Temp. da água & ${ }^{\circ} \mathrm{C}$ & 13 & 13 & 13 & 19 & 17 & 18 & - \\
\hline Oxigênio Diss. & $\mathrm{mg} \mathrm{O}_{2} / \mathrm{L}$ & 0,97 & 4,14 & 0,49 & 7,7 & 7,9 & 0,2 & $\geq 5$ \\
\hline pH & - & 7,2 & 7 & 6,5 & 7,5 & 7 & 6,5 & 6 a 9 \\
\hline Alcalinidade & $\mathrm{mg} \mathrm{CaCO}_{3} / \mathrm{L}$ & 54,5 & 45 & 44,8 & 44 & 49,2 & 50,8 & - \\
\hline Dureza & $\mathrm{mg} \mathrm{CaCO}_{3} / \mathrm{L}$ & 46,7 & 35,4 & 35 & 42,7 & 39,9 & 37 & - \\
\hline Cloreto & $\mathrm{mg} \mathrm{Cl} / \mathrm{L}$ & 29,9 & 25,4 & 22,3 & 28,8 & 28,5 & 28,4 & 250 \\
\hline Sulfato & $\mathrm{mg} \mathrm{SO}_{4} / \mathrm{L}$ & 11,9 & 9,8 & 4,5 & 11,4 & 10,5 & 2,5 & 250 \\
\hline Condutividade & $\mu \mathrm{mho} / \mathrm{cm}$ & 216 & 197,6 & 174,7 & 229 & 235 & 196,3 & - \\
\hline Cor & UC & 105 & 50 & 150 & 100 & 80 & 100 & 75 \\
\hline Turbidez & UNT & 22,4 & 6,3 & 28,5 & 69,8 & 9,62 & 26,2 & 100 \\
\hline Sol. Totais & & 158 & 182 & 194 & 186 & 308 & 112 & - \\
\hline DBO & $\mathrm{mg} \mathrm{O}_{2} / \mathrm{L}$ & $<5$ & $<5$ & $<5$ & 13,5 & 6 & 7 & $\leq 5$ \\
\hline DQO & $\mathrm{mg} \mathrm{O}_{2} / \mathrm{L}$ & 65 & 52 & 38 & 108 & 68 & 47 & - \\
\hline Fósforo Total & $\mathrm{mg} \mathrm{P/L}$ & 0,067 & 0,042 & 0,04 & 0,117 & 0,047 & 0,041 & 0,05 \\
\hline N-Albuminóide & $\mathrm{mg} \mathrm{N} / \mathrm{L}$ & 1,03 & 0,79 & 0,52 & 2,28 & 1,11 & 0,73 & - \\
\hline N-Amoniacal & $\mathrm{mg} \mathrm{N} / \mathrm{L}$ & 1,71 & 1,36 & 0,32 & 0,92 & 1,68 & 0,9 & $3,7 \mathrm{pH} \leq 7,5$ \\
\hline Nitrato & $\mathrm{mg} \mathrm{N} / \mathrm{L}$ & 0,15 & $<0,10$ & $<0,10$ & $<0,10$ & $<0,10$ & $<0,10$ & 10,0 \\
\hline Nitrito & $\mathrm{mg} \mathrm{N} / \mathrm{L}$ & 0,012 & $<0,001$ & $<0,001$ & 0,004 & $<0,001$ & $<0,001$ & 1,0 \\
\hline Bário & $\mathrm{mg} \mathrm{Ba} / \mathrm{L}$ & $<0,05$ & $<0,05$ & $<0,05$ & 0,05 & 0,05 & $<0,05$ & 0,7 \\
\hline Cádmio & $\mathrm{mg} \mathrm{Cd} / \mathrm{L}$ & 0,0010 & 0,0011 & 0,0008 & 0,0012 & 0,0010 & 0,0007 & 0,001 \\
\hline Chumbo & $\mathrm{mg} \mathrm{Pb/L}$ & 0,0062 & 0,0096 & 0,0058 & 0,0150 & 0,0180 & 0,0150 & 0,01 \\
\hline Cobre & $\mathrm{mg} \mathrm{Cu} / \mathrm{L}$ & $<0,02$ & $<0,02$ & $<0,02$ & $<0,02$ & $<0,02$ & $<0,02$ & - \\
\hline Cromo & $\mathrm{mg} \mathrm{Cr} / \mathrm{L}$ & $<0,003$ & $<0,003$ & $<0,003$ & $<0,003$ & $<0,003$ & $<0,003$ & 0,05 \\
\hline Ferro Total & $\mathrm{mg} \mathrm{Fe} / \mathrm{L}$ & 0,49 & 0,35 & 0,52 & 0,66 & 0,52 & 1,82 & - \\
\hline Manganês Total & $\mathrm{mg} \mathrm{Mn} / \mathrm{L}$ & 0,37 & 0,09 & 0,4 & 0,12 & 0,05 & 0,04 & 0,1 \\
\hline Mercúrio & $\mathrm{mg} \mathrm{Hg} / \mathrm{L}$ & $<0,0005$ & $<0,0005$ & $<0,0005$ & $<0,0005$ & $<0,0005$ & $<0,0005$ & 0,0002 \\
\hline Prata & $\mathrm{mg} \mathrm{Ag} / \mathrm{L}$ & $<0,001$ & $<0,001$ & $<0,001$ & $<0,001$ & $<0,001$ & $<0,001$ & 0,01 \\
\hline Selênio & $\mathrm{mg} \mathrm{Se} / \mathrm{L}$ & $<0,001$ & $<0,001$ & $<0,001$ & $<0,001$ & $<0,001$ & $<0,001$ & 0,01 \\
\hline Zinco & $\mathrm{mg} \mathrm{Zn/L}$ & $<0,05$ & $<0,05$ & $<0,05$ & $<0,05$ & $<0,05$ & $<0,05$ & 0,18 \\
\hline Coli. Totais & $\mathrm{NMP} / 100 \mathrm{~mL}$ & 23590 & 14136 & 19863 & 24192 & 24192 & 6867 & 5.000 \\
\hline $\begin{array}{l}\text { Coli } \\
\text { Termotolerantes }\end{array}$ & NMP/100mL & 31 & 20 & 432 & 82 & 41 & 52 & 1000 \\
\hline
\end{tabular}


Tabela 37: Variação dos valores da concentração das variáveis durante os meses de março e abril de 2005 .

\begin{tabular}{|c|c|c|c|c|c|c|c|c|}
\hline \multicolumn{8}{|c|}{ CONCENTRAÇÃO DAS VARIÁVEIS 2005} & \multirow{3}{*}{$\begin{array}{l}\text { CONAMA } \\
357 / 2005 \\
\text { Classe } 02\end{array}$} \\
\hline \multirow[b]{2}{*}{ VARIÁVEIS } & \multirow[b]{2}{*}{ UNIDADES } & \multicolumn{3}{|c|}{ MARÇO } & \multicolumn{3}{|c|}{ ABRIL } & \\
\hline & & $\begin{array}{c}\text { P1 } \\
\text { Entrada } \\
\text { Sistema }\end{array}$ & $\begin{array}{c}\text { P2 } \\
\text { Saída do } \\
\text { MAFE }\end{array}$ & $\begin{array}{c}\text { P3 } \\
\text { Saída } \\
\text { Sistema }\end{array}$ & $\begin{array}{c}\text { P1 } \\
\text { Entrada } \\
\text { Sistema }\end{array}$ & $\begin{array}{c}\text { P2 } \\
\text { Saída do } \\
\text { MAFE }\end{array}$ & $\begin{array}{c}\text { P3 } \\
\text { Saída } \\
\text { Sistema }\end{array}$ & \\
\hline Temp. do ar & ${ }^{\circ} \mathrm{C}$ & 25 & 25 & 25 & 29 & 29 & 29 & - \\
\hline Temp. da água & ${ }^{\circ} \mathrm{C}$ & 25 & 25 & 25 & 24 & 24 & 23 & - \\
\hline pH & - & 7,5 & 6,9 & 6,2 & 7,6 & 6,7 & 6,3 & 6 a 9 \\
\hline Cloreto & $\mathrm{mg} \mathrm{Cl} / \mathrm{L}$ & 24,88 & 20,97 & 18,73 & 26,74 & 25,18 & 23,85 & 250 \\
\hline Condutividade & $\mu \mathrm{mho} / \mathrm{cm}$ & 180,2 & 160 & 155 & 211 & 208 & 186 & - \\
\hline Cor & UC & 250 & 50 & 60 & 160 & 130 & 110 & 75 \\
\hline Turbidez & UNT & 58,9 & 4,66 & 5,93 & 53,3 & 23,6 & 10,5 & 100 \\
\hline DQO & $\mathrm{mg} \mathrm{O}_{2} / \mathrm{L}$ & 98 & 69 & 23 & 86 & 73 & 7 & - \\
\hline Fósforo Total & $\mathrm{mg} \mathrm{P/L}$ & 0,14 & 0,143 & 0,035 & 0,135 & 0,079 & 0,046 & 0,05 \\
\hline N-Amoniacal & $\mathrm{mg} \mathrm{N} / \mathrm{L}$ & 0,47 & 0,16 & 0,16 & 0,099 & 0,302 & 0,464 & $\begin{array}{l}3,7 \mathrm{pH} \leq 7,5 \\
2,0 \quad 7,5<\mathrm{pH}<8,0\end{array}$ \\
\hline Ferro Total & $\mathrm{mg} \mathrm{Fe} / \mathrm{L}$ & 0,36 & 3,05 & 1,16 & 0,457 & 2,279 & 2,289 & - \\
\hline Manganês Total & $\mathrm{mg} \mathrm{Mn} / \mathrm{L}$ & 0,14 & 0,31 & 0,06 & 0,128 & 0,07 & 0,07 & 0,1 \\
\hline Fenóis & $\mathrm{mgFenol} / \mathrm{L}$ & 0,0079 & 0,0058 & 0,0044 & 0,00011 & 0,00124 & 0 & 0,003 \\
\hline
\end{tabular}


Tabela 38: Variação dos valores da concentração das variáveis durante os meses de maio e junho de 2005.

\begin{tabular}{|c|c|c|c|c|c|c|c|c|}
\hline \multicolumn{8}{|c|}{ CONCENTRAÇÃO DAS VARIÁVEIS 2005} & \multirow{3}{*}{$\begin{array}{l}\text { CONAMA } \\
357 / 2005 \\
\text { Classe } 02\end{array}$} \\
\hline \multirow[b]{2}{*}{ VARIÁVEIS } & \multirow[b]{2}{*}{ UNIDADES } & \multicolumn{3}{|c|}{ MAIO } & \multicolumn{3}{|c|}{ JUNHO } & \\
\hline & & $\begin{array}{c}\text { P1 } \\
\text { Entrada } \\
\text { Sistema }\end{array}$ & $\begin{array}{c}\text { P2 } \\
\text { Saída do } \\
\text { MAFE }\end{array}$ & $\begin{array}{c}\text { P3 } \\
\text { Saída } \\
\text { Sistema }\end{array}$ & $\begin{array}{c}\text { P1 } \\
\text { Entrada } \\
\text { Sistema }\end{array}$ & \begin{tabular}{|c|} 
P2 \\
Saída do \\
MAFE
\end{tabular} & $\begin{array}{c}\text { P3 } \\
\text { Saída } \\
\text { Sistema }\end{array}$ & \\
\hline Temp. do ar & ${ }^{\circ} \mathrm{C}$ & 21 & 21 & 21 & 20 & 20 & 20 & - \\
\hline Temp. da água & ${ }^{\circ} \mathrm{C}$ & 20 & 20 & 20 & 18 & 18 & 18 & - \\
\hline $\mathrm{pH}$ & - & 7,74 & 6,77 & 6,4 & 7,6 & 6,7 & 6,1 & 6 a 9 \\
\hline Cloreto & $\mathrm{mg} \mathrm{Cl} / \mathrm{L}$ & 29,33 & 28,72 & 28,96 & 26 & 22,17 & 17,31 & 250 \\
\hline Condutividade & $\mu \mathrm{mho} / \mathrm{cm}$ & 229 & 218 & 212 & 253 & 166,2 & 183,5 & - \\
\hline Cor & UC & 70 & 40 & 140 & 80 & 30 & 50 & 75 \\
\hline Turbidez & UNT & 59,7 & 1,36 & 6,39 & 35,4 & 1,25 & 6,58 & 100 \\
\hline DQO & $\mathrm{mg} \mathrm{O}_{2} / \mathrm{L}$ & 96 & 32 & 42 & 66 & 36 & 26 & - \\
\hline Fósforo Total & $\mathrm{mg} P / \mathrm{L}$ & 0,108 & 0,03 & 0,044 & 0,121 & 0,031 & 0,03 & 0,025 \\
\hline N-Amoniacal & $\mathrm{mg} \mathrm{N} / \mathrm{L}$ & 1,088 & 1,193 & 0,304 & 1,24 & 0,23 & 0,12 & $\begin{array}{ll}3,7 & \mathrm{pH} \leq 7,5 \\
2,0 & 7,5<\mathrm{pH}<8,0\end{array}$ \\
\hline Bário & $\mathrm{mg} \mathrm{Ba} / \mathrm{L}$ & - & - & - & $<0,05$ & - & $<0,05$ & 0,7 \\
\hline Cobre & $\mathrm{mg} \mathrm{Cu} / \mathrm{L}$ & - & - & - & $<0,02$ & - & $<0,02$ & - \\
\hline Cromo & $\mathrm{mg} \mathrm{Cr} / \mathrm{L}$ & - & - & - & $<0,003$ & - & $<0,003$ & 0,05 \\
\hline Ferro Total & $\mathrm{mg} \mathrm{Fe} / \mathrm{L}$ & 0,785 & 0,506 & 1,601 & 0,656 & 0,646 & 1,253 & - \\
\hline Manganês Total & $\mathrm{mg} \mathrm{Mn} / \mathrm{L}$ & 0,18 & 0,04 & 0,047 & 0,146 & 0,07 & 0,045 & 0,1 \\
\hline Mercúrio & $\mathrm{mg} \mathrm{Hg} / \mathrm{L}$ & - & - & - & $<0,0005$ & - & $<0,0005$ & 0,0002 \\
\hline Prata & $\mathrm{mg} \mathrm{Ag} / \mathrm{L}$ & - & - & - & 0,001 & - & $<0,001$ & 0,01 \\
\hline Zinco & $\mathrm{mg} \mathrm{Zn/L}$ & - & - & - & $<0,05$ & - & $<0,05$ & 0,18 \\
\hline Fenóis & $\mathrm{mg}$ Fenol/L & 0,0015 & 0,0006 & 0,0027 & 0,0007 & - & 0,0014 & 0,003 \\
\hline
\end{tabular}


Tabela 39: Variação dos valores da concentração das variáveis durante os meses de julho e agosto de 2005 .

\begin{tabular}{|c|c|c|c|c|c|c|c|c|}
\hline \multicolumn{8}{|c|}{ CONCENTRAÇÃO DAS VARIÁVEIS 2005} & \multirow{3}{*}{$\begin{array}{l}\text { CONAMA } \\
357 / 2005 \\
\text { Classe } 02\end{array}$} \\
\hline \multirow[b]{2}{*}{ VARIÁVEIS } & \multirow[b]{2}{*}{ UNIDADES } & \multicolumn{3}{|c|}{ JULHO } & \multicolumn{3}{|c|}{ AGOSTO } & \\
\hline & & $\begin{array}{c}\text { P1 } \\
\text { Entrada } \\
\text { Sistema }\end{array}$ & $\begin{array}{c}\text { P2 } \\
\text { Saída do } \\
\text { MAFE }\end{array}$ & $\begin{array}{c}\text { P3 } \\
\text { Saída } \\
\text { Sistema }\end{array}$ & $\begin{array}{c}\text { P1 } \\
\text { Entrada } \\
\text { Sistema }\end{array}$ & \begin{tabular}{|c|} 
P2 \\
Saída do \\
MAFE
\end{tabular} & $\begin{array}{c}\text { P3 } \\
\text { Saída } \\
\text { Sistema }\end{array}$ & \\
\hline Temp. do ar & ${ }^{\circ} \mathrm{C}$ & 18 & 18 & 18 & 18 & 18 & 19 & - \\
\hline Temp. da água & ${ }^{\circ} \mathrm{C}$ & 17 & 16 & 16 & 18 & 18 & 20 & - \\
\hline pH & - & 7,3 & 6,7 & 6,4 & 7,4 & 7 & 6,5 & 6 a 9 \\
\hline Cloreto & $\mathrm{mg} \mathrm{Cl} / \mathrm{L}$ & 24,59 & 23,56 & 24,14 & 25,38 & 25,94 & 26,88 & 250 \\
\hline Condutividade & $\mu \mathrm{mho} / \mathrm{cm}$ & 276 & 245 & 209 & 246 & 227 & 225 & - \\
\hline Cor & UC & 100 & 30 & 35 & 80 & 40 & 40 & 75 \\
\hline Turbidez & UNT & 32,8 & 2,23 & 4,16 & 17 & 1,39 & 2,39 & 100 \\
\hline DQO & $\mathrm{mg} \mathrm{O}_{2} / \mathrm{L}$ & 58 & 23 & 30 & 43 & 29 & 21 & - \\
\hline Fósforo Total & $\mathrm{mg} P / \mathrm{L}$ & 0,084 & 0,023 & 0,024 & 0,084 & 0,025 & 0,039 & 0,05 \\
\hline N-Amoniacal & $\mathrm{mg} \mathrm{N} / \mathrm{L}$ & 0,62 & 1,24 & 0,04 & 2,35 & 0,16 & 0,12 & $3,7 \mathrm{pH} \leq 7,5$ \\
\hline Ferro Total & $\mathrm{mg} \mathrm{Fe} / \mathrm{L}$ & 0,375 & 0,479 & 0,68 & 0,457 & 0,414 & 0,841 & - \\
\hline Manganês Total & $\mathrm{mg} \mathrm{Mn/L}$ & 0,09 & 0,03 & 0,04 & 0,133 & 0,05 & 0,02 & 0,1 \\
\hline Fenóis & $\mathrm{mg} \mathrm{Fenol/L}$ & 0,0068 & 0,0010 & 0,0005 & 0,0091 & 0,0029 & 0,0031 & 0,003 \\
\hline
\end{tabular}

Tabela 40: Variação dos valores da concentração das variáveis durante o mês de setembro de 2005.

\begin{tabular}{|c|c|c|c|c|c|}
\hline \multicolumn{5}{|c|}{ CONCENTRAÇÃO DAS VARIÁVEIS 2005} & \multirow{3}{*}{$\begin{array}{l}\text { CONAMA } \\
357 / 2005 \\
\text { Classe } 02\end{array}$} \\
\hline \multirow[b]{2}{*}{ VARIÁVEIS } & \multirow[b]{2}{*}{ UNIDADES } & \multicolumn{3}{|c|}{ SETEMBRO } & \\
\hline & & $\begin{array}{c}\text { P1 } \\
\text { Entrada } \\
\text { Sistema }\end{array}$ & $\begin{array}{c}\text { P2 } \\
\text { Saída do } \\
\text { MAFE }\end{array}$ & $\begin{array}{c}\text { P3 } \\
\text { Saída } \\
\text { Sistema }\end{array}$ & \\
\hline Temp. do ar & ${ }^{\circ} \mathrm{C}$ & 29 & 29 & 29 & - \\
\hline Temp. da água & ${ }^{\circ} \mathrm{C}$ & 22 & 21 & 21 & - \\
\hline $\mathrm{pH}$ & - & 7,7 & 7 & 6,7 & 6 a 9 \\
\hline Cloreto & $\mathrm{mg} \mathrm{Cl} / \mathrm{L}$ & 26,26 & 25,63 & 28,49 & 250 \\
\hline Condutividade & $\mu \mathrm{mho} / \mathrm{cm}$ & 257 & 243 & 229 & - \\
\hline Cor & UC & 110 & 60 & 80 & 75 \\
\hline Turbidez & UNT & 34,1 & 3,92 & 4,04 & 100 \\
\hline DQO & $\mathrm{mg} \mathrm{O} / \mathrm{L}$ & 73 & 42 & 29 & - \\
\hline Fósforo Total & $\mathrm{mg} P / \mathrm{L}$ & 0,123 & 0,032 & 0,029 & 0,05 \\
\hline N-Amoniacal & $\mathrm{mg} \mathrm{N} / \mathrm{L}$ & 1,95 & 1,15 & 0,31 & $3,7 \mathrm{pH} \leq 7,5$ \\
\hline Ferro Total & $\mathrm{mg} \mathrm{Fe} / \mathrm{L}$ & 0,6 & 0,621 & 1,522 & - \\
\hline Manganês Total & $\mathrm{mg} \mathrm{Mn} / \mathrm{L}$ & 0,14 & 0,065 & 0,06 & 0,1 \\
\hline Fenóis & $\mathrm{mg} \mathrm{Fenol/L}$ & 0,0039 & 0,0058 & 0,0009 & 0,003 \\
\hline
\end{tabular}


Tabela 41: Dados sobre o desvio padrão das variáveis em 2004

\begin{tabular}{|l|c|c|c|}
\hline \multirow{2}{*}{\multicolumn{1}{c|}{ VARIÁVEIS }} & \multicolumn{3}{c|}{ 2004 (desvio padrão) } \\
\cline { 2 - 4 } & P1 & P2 & P3 \\
\hline OD & 3,0 & 1,6 & 3,3 \\
PH & 0,2 & 0,2 & 0,3 \\
Alcalinidade & 7,50 & 10,41 & 11,34 \\
Dureza & 5,25 & 4,93 & 5,44 \\
Cloretos & 2,09 & 4,17 & 4,04 \\
Sulfatos & 1,01 & 1,05 & 3,29 \\
Condutividade & 20,5 & 40,0 & 25,5 \\
Cor & 34,3 & 12,6 & 41,1 \\
Turbidez & 22,1 & 2,2 & 10,4 \\
Sólidos Totais & 18,9 & 122,0 & 60,5 \\
DBO & 5,2 & 2,9 & 2,7 \\
DQO & 18,9 & 7,2 & 7,5 \\
Fósforo Total & 0,028 & 0,009 & 0,008 \\
N-Albuminóide & 0,530 & 0,164 & 0,202 \\
N-Amoniacal & 0,585 & 0,807 & 0,372 \\
Cádmio & 0,0004 & 0,0002 & 0,0004 \\
Ferro Total & 0,17 & 0,10 & 1,03 \\
Manganês Total & 0,14 & 0,03 & 0,18 \\
Coli Totais & 7566,0 & 85998,3 & 48755,0 \\
Coli Termotolerantes & 582,7 & 91,9 & 443,4 \\
\hline
\end{tabular}

Tabela 42: Dados sobre o desvio padrão das variáveis em 2005

\begin{tabular}{|l|c|c|c|}
\hline \multirow{2}{*}{\multicolumn{1}{|c|}{ VARIÁVEIS }} & \multicolumn{3}{c|}{2005 (desvio padrão) } \\
\cline { 2 - 4 } & $\mathrm{P} 1$ & $\mathrm{P} 2$ & $\mathrm{P} 3$ \\
\hline pH & 0,16 & 0,14 & 0,2 \\
Cor & 64,14 & 35,05 & 39,0 \\
Turbidez & 16,03 & 8,10 & 2,6 \\
Condutividade & 32,19 & 34,37 & 26,4 \\
Ferro Total & 0,16 & 1,07 & 0,5 \\
Manganês Total & 0,027 & 0,098 & 0,016 \\
Cloretos & 1,59 & 2,59 & 4,58 \\
DQO & 20,35 & 19,76 & 10,6 \\
Fenóis & 0,00367 & 0,00240 & 0,00158 \\
Fósforo Total & 0,023 & 0,045 & 0,008 \\
Nitrogênio Amoniacal & 0,81 & 0,53 & 0,1 \\
\hline
\end{tabular}


APÊNDICE B - Taxas de remoção parcial e total do sistema para as diversas variáveis durante o período de estudo de 2004 e 2005.

Tabelas 43 a 48 
Tabela 43: Eficiência total e de cada uma das etapas do sistema de alagados construídos na remoção das variáveis no mês de fevereiro e março de 2004.

\begin{tabular}{|l|c|c|c|c|c|c|}
\hline \multirow{2}{*}{\multicolumn{1}{|c|}{ VARIÁVEIS }} & \multicolumn{5}{c|}{ EFICIÊNCIA DE REMOÇÃO 2004 (\%) } \\
\cline { 2 - 7 } & \multicolumn{3}{|c|}{ FEVEREIRO } & \multicolumn{3}{c|}{ MARÇO } \\
\cline { 2 - 7 } & CANAL & DHS & TOTAL & CANAL & DHS & TOTAL \\
\hline Alcalinidade Total & 29,2 & $-0,8$ & 28,7 & 17,6 & 9,9 & 25,8 \\
\hline Dureza & 17,4 & 12,7 & 27,9 & 9,1 & 11,1 & 19,2 \\
\hline Cloreto & 28,9 & 0,5 & 29,3 & 10,0 & 1,2 & 11,1 \\
\hline Sulfato & 28,6 & 0,0 & 28,6 & 7,7 & 33,3 & 38,5 \\
\hline Condutividade & 25,0 & 0,7 & 25,5 & 18,6 & 0,0 & 18,6 \\
\hline Cor & 65,7 & 16,7 & 71,4 & 53,8 & $-83,3$ & 15,4 \\
\hline Turbidez & 78,2 & 45,9 & 88,2 & 59,3 & $-133,9$ & 4,9 \\
\hline Sólidos Totais & - & - & - & 15,5 & $-7,3$ & 9,3 \\
\hline DBO & 28,6 & 30,0 & 50,0 & 35,5 & 17,3 & 46,7 \\
\hline DQO & 13,2 & 15,2 & 26,3 & 12,3 & 31,3 & 39,7 \\
\hline Fósforo Total & 75,8 & $-87,1$ & 54,7 & 39,1 & 7,5 & 43,7 \\
\hline N-Albuminóide & 38,5 & 14,8 & 47,6 & 36,6 & 8,2 & 41,8 \\
\hline N-Amoniacal & 35,7 & 33,3 & 57,1 & 88,8 & $-9,1$ & 87,8 \\
\hline Nitrato & - & - & - & - & - & - \\
\hline Nitrito & - & - & - & $>66,7$ & - & $>66,7$ \\
\hline Cádmio & $>-20,0$ & $>20$ & - & $-12,5$ & 33,3 & 25,0 \\
\hline Ferro Total & 49,4 & 53,3 & 76,4 & 44,6 & $-661,3$ & $-321,4$ \\
\hline Manganês Total & 75,0 & $>33,3$ & $>83,3$ & 50,0 & $-133,3$ & $-16,7$ \\
\hline Coli. Totais & -77 & 62,2 & 33,2 & $-505,2$ & 50,6 & $-198,7$ \\
\hline Coli. Temotolerantes & 81,8 & 98,1 & 99,6 & 23,1 & $-3050,0$ & $-2323,1$ \\
\hline
\end{tabular}


Tabela 44: Eficiência total e de cada uma das etapas do sistema de alagados construídos na remoção das variáveis no mês de junho e julho de 2004 .

\begin{tabular}{|l|c|c|c|c|c|c|}
\hline \multirow{3}{*}{\multicolumn{1}{|c|}{ VARIÁVEIS }} & \multicolumn{5}{|c|}{ EFICIÊNCIA DE REMOÇÃO 2004 (\%) } \\
\cline { 2 - 7 } & \multicolumn{3}{|c|}{ JUNHO } & \multicolumn{3}{c|}{ JULHO } \\
\cline { 2 - 7 } & CANAL & DHS & TOTAL & CANAL & DHS & TOTAL \\
\hline Alcalinidade Total & 17,4 & 0,4 & 17,8 & $-11,8$ & $-3,3$ & $-15,4$ \\
\hline Dureza & 24,2 & 1,1 & 25,1 & 6,7 & 7,2 & 13,3 \\
\hline Cloreto & 15,1 & 12,2 & 25,4 & 1,0 & 0,4 & 1,4 \\
\hline Sulfato & 17,4 & 54,5 & 62,4 & 7,7 & 76,5 & 78,3 \\
\hline Condutividade & 8,5 & 11,6 & 19,1 & $-2,6$ & 16,5 & 14,3 \\
\hline Cor & 52,4 & -200 & $-42,9$ & 20 & -25 & 0,0 \\
\hline Turbidez & 73,2 & $-352,4$ & $-27,2$ & 86,2 & $-172,3$ & 62,5 \\
\hline Sólidos Totais & $-15,2$ & $-6,6$ & $-22,8$ & $-65,6$ & 63,6 & 39,8 \\
\hline DBO & - & - & - & 55,6 & $-16,7$ & 48,1 \\
\hline DQO & 20,0 & 26,9 & 41,5 & 37,0 & 30,9 & 56,5 \\
\hline Fósforo Total & 37,3 & 4,8 & 40,3 & 59,8 & 12,8 & 65,0 \\
\hline N-Albuminóide & 23,3 & 34,2 & 49,5 & 51,3 & 34,2 & 68,0 \\
\hline N-Amoniacal & 20,5 & 76,5 & 81,3 & $-82,6$ & 46,4 & 2,2 \\
\hline Nitrato & $>33,3$ & - & $>33,3$ & - & - & - \\
\hline Nitrito & $>91,7$ & - & $>91,7$ & $>75,0$ & - & $>75,0$ \\
\hline Cádmio & $-10,0$ & 27,3 & 20,0 & 16,7 & 30,0 & 41,7 \\
\hline Chumbo & $-54,8$ & 39,6 & 6,5 & $-20,0$ & 16,7 & 0,0 \\
\hline Ferro Total & 28,6 & $-48,6$ & $-6,1$ & 21,2 & -250 & $-175,8$ \\
\hline Manganês Total & 75,7 & $-344,4$ & $-8,1$ & 58,3 & 20,0 & 66,7 \\
\hline Coli. Totais & 40,1 & $-40,5$ & 15,8 & 0,0 & 71,6 & 71,6 \\
\hline Coli Termotolerantes & 35,5 & -2060 & $-1293,5$ & 50,0 & $-26,8$ & 36,6 \\
\hline
\end{tabular}


Tabela 45: Eficiência total e de cada uma das etapas do sistema de alagados construídos na remoção das variáveis no mês de março e abril de 2005.

\begin{tabular}{|l|c|c|c|c|c|c|}
\hline \multirow{3}{*}{ VARIÁVEIS } & \multicolumn{5}{c|}{ EFICIÊNCIA DE REMOÇÃO 2005 (\%) } \\
\cline { 2 - 7 } & \multicolumn{4}{|c|}{ MARÇO } & \multicolumn{3}{c|}{ ABRIL } \\
\cline { 2 - 7 } & CANAL & DHS & TOTAL & CANAL & DHS & TOTAL \\
\hline Cloreto & 15,7 & 10,7 & 24,7 & 5,8 & 5,3 & 10,8 \\
\hline Condutividade & 11,2 & 3,1 & 14,0 & 1,4 & 10,6 & 11,8 \\
\hline Cor & 80,0 & $-20,0$ & 76,0 & 18,8 & 15,4 & 31,3 \\
\hline Turbidez & 92,1 & $-27,3$ & 89,9 & 55,7 & 55,5 & 80,3 \\
\hline DQO & 29,6 & 66,7 & 76,5 & 15,1 & 90,4 & 91,9 \\
\hline Fósforo Total & $-2,1$ & 75,5 & 75,0 & 41,5 & 41,8 & 65,9 \\
\hline N-Amoniacal & 66,0 & 0,0 & 66,0 & $-205,1$ & $-53,6$ & $-368,7$ \\
\hline Ferro Total & $-747,2$ & 62,0 & $-222,2$ & $-398,7$ & $-0,4$ & $-400,9$ \\
\hline Manganês Total & $-121,4$ & 80,6 & 57,1 & 45,3 & 0,0 & 45,3 \\
\hline Fenóis & 26,6 & 24,1 & 44,3 & $-1050,0$ & 100,0 & 100,0 \\
\hline
\end{tabular}

Tabela 46: Eficiência total e de cada uma das etapas do sistema de alagados construídos na remoção das variáveis no mês de maio e junho de 2005 .

\begin{tabular}{|l|c|c|c|c|c|c|}
\hline \multirow{3}{*}{ VARIÁVEIS } & \multicolumn{5}{|c|}{ EFICIÊNCIA DE REMOÇÃO 2005 (\%) } \\
\cline { 2 - 7 } & \multicolumn{5}{|c|}{ MAIO } & \multicolumn{3}{c|}{ JUNHO } \\
\cline { 2 - 7 } & CANAL & DHS & TOTAL & CANAL & DHS & TOTAL \\
\hline Cloreto & 2,1 & $-0,8$ & 1,3 & 14,7 & 21,9 & 33,4 \\
\hline Condutividade & 4,8 & 2,8 & 7,4 & 34,3 & $-10,4$ & 27,5 \\
\hline Cor & 42,9 & $-250,0$ & $-100,0$ & 62,5 & $-66,7$ & 37,5 \\
\hline Turbidez & 97,7 & $-369,9$ & 89,3 & 96,5 & $-426,4$ & 81,4 \\
\hline DQO & 66,7 & $-31,3$ & 56,3 & 45,5 & 27,8 & 60,6 \\
\hline Fósforo Total & 72,2 & $-46,7$ & 59,3 & 74,4 & 3,2 & 75,2 \\
\hline N-Amoniacal & $-9,7$ & 74,5 & 72,1 & 81,5 & 47,8 & 90,3 \\
\hline Ferro Total & 35,5 & $-216,4$ & $-103,9$ & 1,5 & $-94,0$ & $-91,0$ \\
\hline Manganês Total & 77,8 & $-17,5$ & 73,9 & 52,1 & 35,7 & 69,2 \\
\hline Fenóis & 60,0 & $-350,0$ & $-80,0$ & - & - & $-100,0$ \\
\hline
\end{tabular}


Tabela 47: Eficiência total e de cada uma das etapas do sistema de alagados construídos na remoção das variáveis no mês de julho e agosto de 2005 .

\begin{tabular}{|l|c|c|c|c|c|c|}
\hline \multirow{3}{*}{ VARIÁVEIS } & \multicolumn{5}{|c|}{ EFICIÊNCIA DE REMOÇÃO 2005 (\%) } \\
\cline { 2 - 7 } & \multicolumn{3}{|c|}{ JULHO } & \multicolumn{3}{c|}{ AGOSTO } \\
\cline { 2 - 7 } & CANAL & DHS & TOTAL & CANAL & DHS & TOTAL \\
\hline Cloreto & 4,2 & $-2,5$ & 1,8 & $-2,2$ & $-3,6$ & $-5,9$ \\
\hline Condutividade & 11,2 & 14,7 & 24,3 & 7,7 & 0,9 & 8,5 \\
\hline Cor & 70,0 & $-16,7$ & 65,0 & 50,0 & 0,0 & 50,0 \\
\hline Turbidez & 93,2 & $-86,5$ & 87,3 & 91,8 & $-71,9$ & 85,9 \\
\hline DQO & 60,3 & $-30,4$ & 48,3 & 32,6 & 27,6 & 51,2 \\
\hline Fósforo Total & 72,6 & $-4,3$ & 71,4 & 70,2 & $-56,0$ & 53,6 \\
\hline N-Amoniacal & $-100,0$ & 96,8 & 93,5 & 93,2 & 25,0 & 94,9 \\
\hline Ferro Total & $-27,7$ & $-42,0$ & $-81,3$ & 9,4 & $-103,1$ & $-84,0$ \\
\hline Manganês Total & 66,7 & $-33,3$ & 55,6 & 62,4 & 60,0 & 85,0 \\
\hline Fenóis & 85,9 & 44,7 & 92,2 & 68,1 & $-6,9$ & 65,9 \\
\hline
\end{tabular}

Tabela 48: Eficiência total e de cada uma das etapas do sistema de alagados construídos na remoção das variáveis no mês de setembro de 2005.

\begin{tabular}{|l|c|c|c|}
\hline \multirow{2}{*}{\multicolumn{1}{|c|}{ VARIÁVEIS }} & \multicolumn{3}{c|}{ EFICIÊNCIA DE REMOÇÃO 2005 (\%) } \\
\cline { 2 - 4 } & \multicolumn{3}{|c|}{ SETEMBRO } \\
\cline { 2 - 4 } & CANAL & DHS & TOTAL \\
\hline Cloreto & 2,4 & $-11,2$ & $-8,5$ \\
\hline Condutividade & 5,4 & 5,8 & 10,9 \\
\hline Cor & 45,5 & $-33,3$ & 27,3 \\
\hline Turbidez & 88,5 & $-3,1$ & 88,2 \\
\hline DQO & 42,5 & 31,0 & 60,3 \\
\hline Fósforo Total & 74,0 & 9,4 & 76,4 \\
\hline N-Amoniacal & 41,0 & 73,0 & 84,1 \\
\hline Ferro Total & $-3,5$ & $-145,1$ & $-153,7$ \\
\hline Manganês Total & 53,6 & 7,7 & 57,1 \\
\hline Fenóis & $-48,7$ & 84,5 & 76,9 \\
\hline
\end{tabular}


APÊNDICE C - MANOVA sobre a matriz 2004/05 testando o efeito da variação anual.

\begin{tabular}{|c|c|c|c|c|c|}
\hline Effect & SS & $d f$ & MS & $\mathrm{F}$ & $\mathrm{P}$ \\
\hline TAR & 0.015 & 1 & 0.015 & 1.855 & 0.192 \\
\hline Error & $\odot .126$ & 16 & $\odot . \odot \odot 8$ & & \\
\hline TAG & $\odot .007$ & 1 & $\odot .0 \odot 7$ & 0.748 & 0.400 \\
\hline Error & 0.144 & 16 & $\odot . \odot \odot 9$ & & \\
\hline CLOR & 0.014 & 1 & 0.014 & 4.654 & 0.047 \\
\hline Error & $\odot .047$ & 16 & $\odot . \odot \odot 3$ & & \\
\hline $\mathrm{PH}$ & 0.142 & 1 & 0.142 & 0.567 & 0.463 \\
\hline Error & 4.016 & 16 & $\odot .251$ & & \\
\hline COND & $\odot . \odot \odot \odot$ & 1 & $\odot .000$ & $\odot .087$ & 0.771 \\
\hline Error & $\odot . \odot 87$ & 16 & $\odot .005$ & & \\
\hline COR & 0.165 & 1 & 0.165 & 3.072 & $\odot .099$ \\
\hline Error & 0.861 & 16 & 0.054 & & \\
\hline TURB & 0.514 & 1 & 0.514 & 2.999 & 0.103 \\
\hline Error & 2.741 & 16 & 0.171 & & \\
\hline DQO & 0.100 & 1 & 0.100 & 2.793 & 0.114 \\
\hline Error & $\odot .570$ & 16 & 0.036 & & \\
\hline PT & $\odot . \odot \odot \odot$ & 1 & $\odot . \odot \odot \odot$ & 0.218 & 0.647 \\
\hline Error & $\odot .0 \odot 4$ & 16 & $\odot .0 \odot \odot$ & & \\
\hline $\mathrm{NH} 4$ & 0.050 & 1 & 0.050 & 2.547 & 0.130 \\
\hline Error & 0.313 & 16 & 0.020 & & \\
\hline FET & 0.003 & 1 & 0.003 & 0.128 & 0.725 \\
\hline Error & 0.345 & 16 & $\odot .022$ & & \\
\hline MN & $\odot .001$ & 1 & $\odot .001$ & 0.303 & 0.590 \\
\hline Error & 0.030 & 16 & 0.002 & & \\
\hline
\end{tabular}

Multivariate Test Statistics

\begin{tabular}{|c|c|c|c|c|c|c|}
\hline $\begin{aligned} \text { Wilks' Lambda } & = \\
\text { F-Statistic } & =\end{aligned}$ & $\begin{array}{l}0.057 \\
6.930\end{array}$ & $d f=$ & 12, & 5 & Prob = & 0.022 \\
\hline $\begin{aligned} \text { Pillai Trace } & = \\
\text { F-Statistic } & =\end{aligned}$ & $\begin{array}{l}\odot .943 \\
6.930\end{array}$ & $d f=$ & 12, & 5 & Prob = & 0.022 \\
\hline $\begin{aligned} \text { Hotelling-Lawley Trace } & = \\
\text { F-Statistic } & =\end{aligned}$ & $\begin{array}{r}16.631 \\
6.930\end{array}$ & $d f=$ & 12, & 5 & Prob = & 0.022 \\
\hline
\end{tabular}


APÊNDICE D - MANOVA sobre a matriz de dados 2004 testando o efeito da remoção nas etapas do sistema.

\begin{tabular}{|c|c|c|c|c|c|}
\hline Effect & SS & $d f$ & MS & $F$ & $\mathrm{P}$ \\
\hline TAR & $\odot .00 \odot$ & 2 & 0.000 & $\odot .000$ & 1.000 \\
\hline Error & 0.097 & 6 & 0.016 & & \\
\hline TAG & $\odot .00 \odot$ & 2 & $\odot .0 \odot \odot$ & $\odot .008$ & $\odot .992$ \\
\hline Error & $\odot .092$ & 6 & 0.015 & & \\
\hline $\mathrm{PH}$ & 1.447 & 2 & 0.723 & 28.304 & 0.001 \\
\hline Error & 0.153 & 6 & 0.026 & & \\
\hline$O D$ & 1.077 & 2 & $\odot .538$ & 10.664 & 0.011 \\
\hline Error & $\odot .303$ & 6 & $\odot .050$ & & \\
\hline COND & 0.010 & 2 & $\odot .005$ & 4.072 & $\odot .076$ \\
\hline Error & $\odot . \odot \odot 7$ & 6 & $\odot . \odot \odot 1$ & & \\
\hline COR & $\odot .139$ & 2 & 0.069 & 9.354 & 0.014 \\
\hline Error & $\odot .044$ & 6 & $\odot . \odot \odot 7$ & & \\
\hline TURB & $\odot .539$ & 2 & 0.270 & 10.130 & 0.012 \\
\hline Error & $\odot .16 \odot$ & 6 & $\odot .027$ & & \\
\hline ALCA & $\odot .0 \odot 4$ & 2 & $\odot .0 \odot 2$ & $\odot .358$ & 0.713 \\
\hline Error & $\odot .034$ & 6 & $\odot .0 \odot 6$ & & \\
\hline CLOR & $\odot .005$ & 2 & $0.0 \odot 2$ & 0.858 & 0.470 \\
\hline Error & ๑. 016 & 6 & $\odot .0 \odot 3$ & & \\
\hline DUR & 0.013 & 2 & 0.006 & 8.069 & 0.020 \\
\hline Error & $\odot .0 \odot 5$ & 6 & $\odot . \odot \odot 1$ & & \\
\hline DBO & 0.116 & 2 & 0.058 & $\odot .760$ & $\odot .508$ \\
\hline Error & $\odot .458$ & 6 & 0.076 & & \\
\hline DQO & 0.107 & 2 & 0.054 & 8.580 & ๑. 017 \\
\hline Error & 0.038 & 6 & $\odot .0 \odot 6$ & & \\
\hline PT & 0.001 & 2 & 0.000 & 9.165 & ๑. 015 \\
\hline Error & $\odot . \odot \odot \odot$ & 6 & $\odot . \odot \odot \odot$ & & \\
\hline $\mathrm{NH} 4$ & 0.056 & 2 & 0.028 & 1.331 & 0.332 \\
\hline Error & 0.127 & 6 & $\odot .021$ & & \\
\hline NALB & $\odot .049$ & 2 & 0.024 & 5.055 & 0.052 \\
\hline Error & $\odot .029$ & 6 & $\odot . \odot \odot 5$ & & \\
\hline ST & 0.049 & 2 & 0.024 & 0.449 & $\odot .658$ \\
\hline Error & 0.324 & 6 & 0.054 & & \\
\hline SULFA & 0.247 & 2 & 0.124 & 8.208 & ๑. 019 \\
\hline Error & $\odot .090$ & 6 & 0.015 & & \\
\hline
\end{tabular}




$\begin{array}{llllll}\text { CD } & 0.000 & 2 & 0.000 & 4.502 & 0.064 \\ \text { Error } & 0.000 & 6 & 0.000 & & \\ \text { FET } & & & & \\ \quad \text { Error } & 0.098 & 2 & 0.049 & 4.270 & 0.070 \\ \text { MN } & 0.069 & 6 & 0.011 & & \\ \quad \text { Error } & 0.004 & 2 & 0.002 & 0.664 & 0.549 \\ \text { (1) } & 0.017 & 6 & 0.003 & & \end{array}$


APÊNDICE E - MANOVA sobre a matriz de dados 2005 testando o efeito da remoção nas etapas do sistema.

\begin{tabular}{|c|c|c|c|c|c|}
\hline Effect & SS & $d f$ & MS & $F$ & $\mathrm{P}$ \\
\hline $\begin{array}{l}\text { TAR } \\
\text { Error }\end{array}$ & $\begin{array}{l}\odot . \odot \odot \odot ~ \\
\odot .128\end{array}$ & $\begin{array}{r}2 \\
17\end{array}$ & $\begin{array}{l}\odot . \odot \odot \odot ~ \\
\odot . \odot \odot ४\end{array}$ & 0.014 & $\odot .986$ \\
\hline $\begin{array}{l}\text { TA } \\
\text { Error }\end{array}$ & $\begin{array}{l}\odot . \odot \odot \odot ~ \\
\odot . \odot 71\end{array}$ & $\begin{array}{r}2 \\
17\end{array}$ & $\begin{array}{l}\odot . \odot \odot \odot ~ \\
\odot . \odot \odot 4\end{array}$ & 0.006 & 0.994 \\
\hline $\begin{array}{l}\mathrm{PH} \\
\text { Error }\end{array}$ & $\begin{array}{l}4.905 \\
\odot .484\end{array}$ & $\begin{array}{r}2 \\
17\end{array}$ & $\begin{array}{l}2.453 \\
0.028\end{array}$ & 86.127 & $\odot .00 \odot$ \\
\hline $\begin{array}{l}\text { COND } \\
\text { Error }\end{array}$ & $\begin{array}{l}\odot .018 \\
\odot .068\end{array}$ & $\begin{array}{r}2 \\
17\end{array}$ & $\begin{array}{l}\odot . \odot \odot 9 \\
\odot . \odot \odot 4\end{array}$ & 2.248 & 0.136 \\
\hline $\begin{array}{l}\text { COR } \\
\text { Error }\end{array}$ & $\begin{array}{l}\odot .366 \\
\odot .759\end{array}$ & $\begin{array}{r}2 \\
17\end{array}$ & $\begin{array}{l}\odot .183 \\
0.045\end{array}$ & 4.094 & $\odot .035$ \\
\hline $\begin{array}{l}\text { TURB } \\
\text { Error }\end{array}$ & $\begin{array}{l}3.351 \\
1.107\end{array}$ & $\begin{array}{r}2 \\
17\end{array}$ & $\begin{array}{l}1.675 \\
0.065\end{array}$ & 25.718 & $\odot .000$ \\
\hline $\begin{array}{l}\text { DQO } \\
\text { Error }\end{array}$ & $\begin{array}{l}\odot .812 \\
\odot .616\end{array}$ & $\begin{array}{r}2 \\
17\end{array}$ & $\begin{array}{l}\odot .406 \\
\odot .036\end{array}$ & 11.217 & 0.001 \\
\hline $\begin{array}{l}\text { PT } \\
\text { Error }\end{array}$ & $\begin{array}{l}\odot . \odot \odot 4 \\
\odot . \odot \odot 2\end{array}$ & $\begin{array}{r}2 \\
17\end{array}$ & $\begin{array}{l}\odot . \odot \odot 2 \\
\odot . \odot \odot \odot\end{array}$ & 13.369 & $\odot .000$ \\
\hline $\begin{array}{l}\text { NHA4 } \\
\text { Error }\end{array}$ & $\begin{array}{l}\odot .164 \\
\odot .295\end{array}$ & $\begin{array}{r}2 \\
17\end{array}$ & $\begin{array}{l}\odot .082 \\
0.017\end{array}$ & 4.721 & $\odot .023$ \\
\hline $\begin{array}{l}\text { FET } \\
\text { Error }\end{array}$ & $\begin{array}{l}\odot .115 \\
\odot .272\end{array}$ & $\begin{array}{r}2 \\
17\end{array}$ & $\begin{array}{l}0.057 \\
0.016\end{array}$ & 3.577 & 0.051 \\
\hline $\begin{array}{l}\text { MN } \\
\text { Error }\end{array}$ & $\begin{array}{l}\odot . \odot \odot 4 \\
\odot . \odot \odot 9\end{array}$ & $\begin{array}{r}2 \\
17\end{array}$ & $\begin{array}{l}\odot . \odot \odot 2 \\
\odot . \odot \odot 1\end{array}$ & 4.147 & 0.034 \\
\hline $\begin{array}{l}\text { FENOIS } \\
\text { Error }\end{array}$ & $\begin{array}{l}\odot . \odot \odot \odot ~ \\
\odot . \odot \odot \odot\end{array}$ & $\begin{array}{r}2 \\
17\end{array}$ & $\begin{array}{l}\odot . \odot \odot \odot ~ \\
\odot . \odot \odot \odot ~\end{array}$ & 1.414 & $\odot .270$ \\
\hline
\end{tabular}

Multivariate Test Statistics

\begin{tabular}{|c|c|c|c|c|c|c|}
\hline $\begin{array}{l}\text { Wilks' Lambda } \\
\text { F-Statistic }\end{array}$ & $\begin{array}{l}0.004 \\
7.844\end{array}$ & $d f=$ & 24, & 12 & Prob = & 0.000 \\
\hline $\begin{array}{l}\text { Pillai Trace } \\
\text { F-Statistic }\end{array}$ & $\begin{array}{l}1.575 \\
2.162\end{array}$ & $d f=$ & 24, & 14 & Prob = & 0.068 \\
\hline $\begin{array}{r}\text { Hotelling-Lawley Trace } \\
\text { F-Statistic }\end{array}$ & $\begin{array}{r}116.354 \\
24.240\end{array}$ & $d f=$ & 24, & 10 & Prob $=$ & 0.000 \\
\hline
\end{tabular}

